
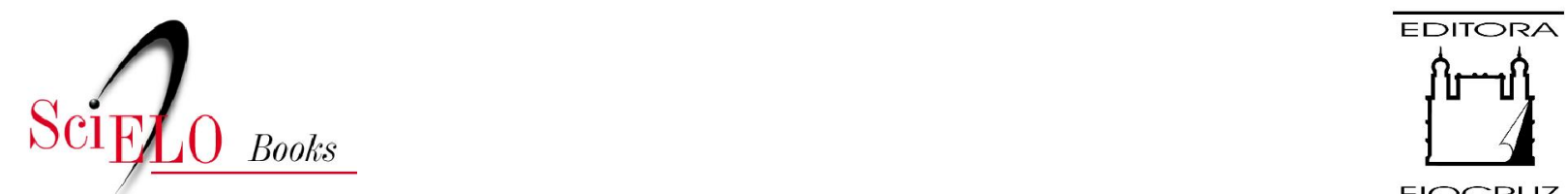

FIOCRUZ

\title{
O corpo na história
}

\author{
José Carlos Rodrigues
}

SciELO Books / SciELO Livros / SciELO Libros

RODRIGUES, JC. O corpo na história [online]. Rio de Janeiro: Editora FIOCRUZ, 1999. Antropologia e saúde collection, 197 p. ISBN: 978-85-7541-555-9. Available from: doi: 10.7476/9788575415559. Also available in ePUB from: http://books.scielo.org/id/p9949/epub/rodrigues-9788575415559.epub

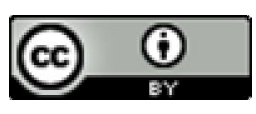

All the contents of this work, except where otherwise noted, is licensed under a Creative Commons Attribution $\underline{4.0 \text { International license. }}$

Todo o conteúdo deste trabalho, exceto quando houver ressalva, é publicado sob a licença Creative Commons Atribição 4.0.

Todo el contenido de esta obra, excepto donde se indique lo contrario, está bajo licencia de la licencia Creative Commons Reconocimento 4.0. 


\section{O Corpo na História}




\section{FUNDAÇÃO OSWALDO CRUZ}

Presidente

Paulo Gadelha

Vice-Presidente de Ensino, Informação e Comunicação

Nísia Trindade Lima

\section{EDITORA FIOCRUZ}

Diretora

Nísia Trindade Lima

Editor Executivo

João Carlos Canossa Pereira Mendes

Editores Científicos

Carlos Machado de Freitas e Gilberto Hochman

Conselho Editorial

Claudia Nunes Duarte dos Santos

Jane Russo

Ligia Maria Vieira da Silva

Maria Cecília de Souza Minayo

Marilia Santini de Oliveira

Moisés Goldbaum

Pedro Paulo Chieffi

Ricardo Lourenço de Oliveira

Ricardo Ventura Santos

Soraya Vargas Côrtes

Coleção Antropologia e Saúde

Editores Responsáveis: Carlos E. A. Coimbra Jr.

Maria Cecília de Souza Minayo 


\title{
O Corpo na História
}

\author{
José Carlos Rodrigues
}

$3^{\text {a }}$ Reimpressão

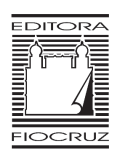


Copyright (C) 1999 do autor

Todos os direitos desta edição reservados à

Fundação Oswaldo CRuZ / Editora

$1^{\text {a }}$ edição: 1999

$1^{\text {a }}$ reimpressão: 2001 | $2^{\text {a }}$ reimpressão: 2007 | $3^{\mathrm{a}}$ reimpressão: 2014

Projeto gráfico e editoração eletrônica

Angélica Mello

Capa

Danowski Design

Ilustração da capa

A partir de desenho de Hans Arp, Indian Ink , 1917

Preparação de originais e copidesque

M. Cecília Gomes Barbosa Moreira

Revisão

Beatriz de Moraes Veira

Catalogação na fonte

Centro de Informação Científica e Tecnológica

Biblioteca Lincoln de Freitas Filho

R696c Rodrigues, José Carlos
O Corpo na História/ José Carlos Rodrigues. - Rio de Janeiro : Editora
Fiocruz, 1999.
198 p. (Coleção Antropologia e Saúde)
ISBN: $85-85239-16-6$
1.Antropologia

2014

EDITORA FIOCRUZ

Av. Brasil, 4036 - 1a andar - sala 112 - Manguinhos

21040-361 - Rio de Janeiro - RJ

Tels:(21)3882-9039 e 3882-9007 / Telefax:(21)3882-9006

editora@fiocruz.br/www.fiocruz.br 
Dedico este trabalho à inesquecível alegria de minha irmã, Maria Júlia, repetindo com o poeta:

Mas as coisas findas, Muito mais que lindas, Essas ficarão... 
... corpo, alma, sociedade, tudo se mistura.

... ainda existem muitas luas mortas, ou pálidas, ou obscuras no firmamento da razão.

Marcel Mauss 
Apresentação 11

Introdução 15

\section{PARTE I}

1. Antes e Depois? 31

2. Fusão e Separação 41

3. Espírito e Matéria 55

4. Seriedade e Riso 65

\section{PARTE II}

5. Proximidade e Distância 83

6. Cidade e Campo 97

7. Higiene e Vigilância 109

8. Indivíduo e Decomposição 121

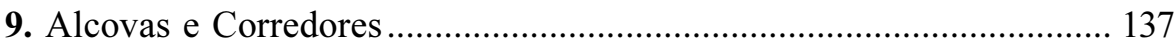

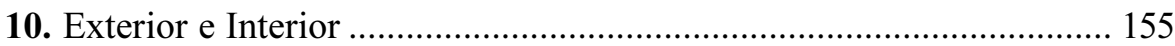

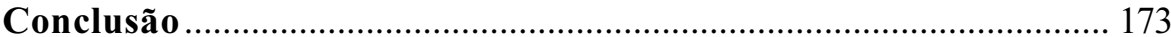

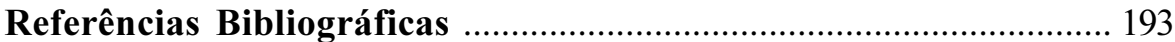




\section{Apresentação}

Aqui estão os resultados parciais de um estudo que venho desenvolvendo há alguns anos, tendo inicialmente por objeto as representações sociais do corpo e da morte. Agora, ainda nas trilhas desta problemática, proponho percorrer algumas das inesgotáveis formas de (in)sensibilidade na cultura ocidental - contatos corporais, suportabilidade de odores, rumores, sabores... Digo que estes resultados são parciais porque fico convencido, a cada passo da pesquisa, que mais venho aprendendo sobre minhas lacunas de conhecimento do que obtendo satisfação com o que penso ter aprendido.

Apesar disso, pude reunir uma quantidade não desprezível de informações, sobre as quais foi possível formular algumas poucas idéias. Entre essas informações, uma parcela ponderável provém de pesquisas de historiadores, sob a forma de variados estudos acerca de temas específicos e localizados, relativos ao corpo: hábitos de toilette, representações da morte, odores, pudores, horrores... Tais estudos históricos correspondem, em geral, à orientação que receberam de Marc Bloch no seu clássico A Sociedade Feudal (1968): "Uma história verdadeiramente digna desse nome, mais que as tímidas tentativas a que nos obrigam hoje os meios postos à nossa disposição, dará às questões do corpo o espaço que elas merecem".

Sendo antropólogo, tentei ser um aprendiz desses historiadores. Ao mesmo tempo, procurei transbordar a especificidade temática das pesquisas localizadas que estes realizam. Arrisquei-me, aqui e ali, a esboçar um quadro amplo e genérico, em que as pesquisas históricas singulares poderiam receber um tratamento globalizante em termos de cultura.

Esta dimensão generalizadora não se limitou a situar os dados que os historiadores nos fornecem, mostrando o que significam no âmbito de um sistema de relações sociais específico, a sociedade ocidental moderna. Este transbordamento se esforçou também por colocar em evidência algo do que penso ter sido possível aprender com os ensinamentos sobre concepções corporais que continuamente nos oferecem os povos e os tempos, dos quais os antropólogos sempre puderam extrair verdadeiros tesouros.

Reconheço que, na aventura que convido o leitor a compartilhar, corro seriamente o risco de desagradar a ambos. Ao historiador, pelo que lhe pode pare- 
cer falta de rigor com a cronologia, desatenção ao detalhe e generalização precipitada. Ao antropólogo, possivelmente, por trabalhar com material de segunda mão, por aparentemente cultuar divindades que não são as oficiais da tribo e por apresentar um trabalho de gabinete, não de campo.

Entretanto, foi conscientemente que resolvi passar por estes perigos. Julguei necessária a organização do presente estágio de meu trabalho de pesquisa. Esta tarefa, em grande medida, requeria a elaboração de um texto em que eu fizesse o exercício de articular algumas informações e algumas idéias desse setor/ estágio de meus estudos, assim como a submissão de meus dados e pensamentos ao crivo de um público mais extenso e, talvez, mais exigente. Isto por um lado.

Por outro, os riscos a que resolvi me expor correspondem a ossos mais ou menos inevitáveis do ofício intelectual. Se a diferença entre as ciências é de ponto de vista, e não de objeto empírico, freqüentemente se é obrigado a passar pelo constrangimento de abordar temáticas que poderiam pretensamente 'pertencer' ao feudo de outra disciplina. Quase sempre, nestes casos, procura-se reduzir o acanhamento, decorrente desta invasão de domicílio, recorrendo-se à justificativa de se estar realizando um estudo inter, multi ou transdisciplinar, buscando-se quase magicamente uma prévia absolvição, ungindo-se com o argumento bem comportado da colaboração entre disciplinas. Em decorrência, estas continuam, como sempre, essencialmente separadas, como se as tradicionais fronteiras disciplinares fossem petreamente inalteráveis. Não concordo muito que as coisas devam ser assim.

Embora reconheça que, em planos específicos, durante as últimas três ou quatro décadas, um diálogo muito rico entre a antropologia e a história nos tenha brindado com resultados extraordinários, não acredito que tenham sido os méritos da inter, trans ou multidisciplinaridade o que de mais precioso se pôde retirar desta experiência. Penso que seja exatamente a indisciplinaridade o ensinamento maior que se deve usufruir de diálogos deste tipo e mesmo de enfrentamentos entre disciplinas diversas: irreverência contra a propriedade privada de campos teóricos e empíricos; insolência contra a canonização de métodos.

Não me parece, absolutamente, que as lições contidas em obras como as de Georges Bataille, Claude Lévi-Strauss, Michel Foucault, Edgar Morin, Gilles Deleuze, Jean Baudrillard, entre tantos outros, possam ser acomodadas nos escaninhos desta ou daquela disciplina específica. Muito menos concordo que sejam inter, multi ou trans qualquer coisa. Fazendo um jogo irônico com as palavras de Lévi-Strauss, embora seguindo seu exemplo, diria, aos que vierem me cobrar um trabalho disciplinar de antropólogo, que a antropologia também "leva a tudo, com a condição de se sair dela".

É muito importante para mim deixar registrados alguns agradecimentos. Ao departamento de Antropologia da Universidade Federal Fluminense, ao qual 
uma versão inicial deste trabalho foi apresentada como tese em um concurso público para professor titular. Na ocasião da apresentação acadêmica deste trabalho, tive a honra de ser examinado pelos professores Luiz de Castro Farias, Roberto DaMatta, Roberto Cardoso de Oliveira, João Baptista Borges Pereira e Sylvio Coelho dos Santos. Destes examinadores, auferi comentários que me sugeriram algumas pequenas modificações, ao mesmo tempo que me encorajaram à publicação. Soulhes agradecido pelo que me ofereceram de boa-fé.

Em virtude da circunstância acadêmica de sua origem, o leitor poderá encontrar nas páginas seguintes uma argumentação e uma linguagem capazes de interessar também ao não-especialista. Isto acontece porque penso que uma tese para professor titular no campo das ciências sociais deva ser um exercício intelectual que demonstre a habilidade de seu autor para interligar pesquisa, ensino e extensão, funções primordiais da universidade. Tal capacidade se deve manifestar principalmente por sua abertura pessoal, assim como a de seu campo acadêmico, à curiosidade de outros.

Por estas razões, procuro neste livro bem mais do que organizar para mim e para meus colegas (antropólogos e pesquisadores especializados em temas como representações do corpo e da morte, mentalidades e sensibilidades corporais) um material segmentar, relativo a assuntos sobre os quais venho trabalhando há mais de vinte anos, pelo menos desde a preparação de minha dissertação de mestrado, entre 1971 e 1974, que resultou na publicação de meu primeiro livro, Tabu do Corpo (1979). Tenho também a ambição de fazê-lo interessante e de dirigi-lo a um público amplo. Esquematizando as coisas (e, de certo modo, exagerando-as bastante), mais do que afirmar verdades - idealmente tarefa do cientista - preferiria por meio deste trabalho suscitar idéias - por excelência missão do professor.

Sou grato igualmente ao departamento de Comunicação Social da Pontifícia Universidade Católica do Rio de Janeiro, pois, a exemplo do primeiro, nele também pude encontrar as condições que propiciaram a realização de mais este trabalho, apesar de todas as dificuldades que sabemos fazer parte de nosso cotidiano universitário. Ao Conselho Nacional de Desenvolvimento Científico e Tecnológico $(\mathrm{CNPq})$, que me tem apoiado durante praticamente toda a carreira como pesquisador e professor, concedendo-me seguidamente bolsas de aperfeiçoamento, mestrado, doutorado no exterior, pesquisa especial e produtividade científica. Com muita freqüência, este suporte incentivou também meus alunos e ex-alunos, alguns dos quais são hoje brilhantes professores e pesquisadores.

Agradeço a Ivone Barros, que transcreveu fitas e fichou livros, muitas vezes trabalhando até alta madrugada, ajudando-me em atividades indispensáveis para o bom andamento do que Wright Mills chamava de "artesanato intelectual", tarefas que, em face de meus presentes compromissos profissionais, são-me praticamente impossíveis de realizar pessoalmente. Expresso gratidão a meus alunos, dos quais muitos, tendo assistido a cursos em que expus parte do material e 
das idéias aqui contidos, incentivaram-me a dar-lhes forma escrita. Deles se poderá sentir a influência a cada linha, como resposta a suas perguntas, dúvidas, silêncios, opacidade ou cintilância de olhares - esses olhares que são como verdadeira bússola para o professor.

A meus amigos, que souberam compreender as muitas e prolongadas ausências que este trabalho exigiu. Entre estes, sou especialmente grato a Marcio Goldman pelo socorro que sempre me pôde prestar nas minhas quase incontornáveis dificuldades de lidar com computadores, sem falar da solidariedade fraternal e da troca intelectual nas conversas que em certos momentos foram cotidianas. Quero também lembrar Mônica, Marisa, Márcia, Monique, Mário, Myres... para, diplomaticamente, entre tantos e tantos amigos, mencionar explicitamente apenas alguns daqueles cujos nomes o destino quis que tivessem essa mesma inicial.

Agradeço também a minha mãe e a meus irmãos, que aceitaram minha inconstância durante a realização deste trabalho, mesmo sem entender muito bem o porquê ou o para quê dela. Também a meu pai, que faleceu quando eu estava absorvido, trabalhando. Quero agradecer sobretudo à minha filha, Aline, desculpando-me imensamente pela aparente distância a que a solidão deste estudo tantas vezes me obrigou. 


\section{Introdução}

A história leva a tudo, com a condição de se entrar nela. Jacques Le Goff

Neste trabalho tentei uma consideração especial de nossa cultura ocidental. Procurei oferecer dela uma apreensão global, quer do ponto de vista dos grandes processos que caracterizaram sua formação, quer, sobretudo, do ângulo dos pequenos fluxos que configuraram as mentalidades e sensibilidades dos seres humanos em que ela se materializou. De modo mais específico, dediquei meus esforços a colocar em evidência alguns dos movimentos que vieram a constituir historicamente esse fenômeno que se chama correntemente de 'subjetividade' contemporânea - uma derivação direta, como veremos, da individualidade moderna.

Proponho, para desenvolver meu projeto, uma espécie de pacto com o leitor: sugerir mais do que afirmar; insinuar tendências que ele poderá testar no laboratório de si mesmo, mais do que invadir o seu espaço. Procurarei falar o mínimo sobre aquilo que, suponho, o leitor possa ver por si só, procurando oferecer-lhe a oportunidade - ora factual, ora conceitual - de dialogar intimamente com os dados e as idéias que estarei apresentando. Por essa via, espero que o leitor dialogue com o meu texto e consigo mesmo.

Gostaria de destacar, de início, ainda que para solicitar alguma complacência ao leitor que deles vier a sentir alguma falta nestas páginas, que os grandes processos econômicos e políticos estão de certo modo razoavelmente bem estudados. Isto é bastante compreensível, pois nossos historiadores e teóricos sempre se dedicaram aos mesmos. A história das mentalidades, por outro lado, embora recente, também tem recebido nas últimas duas, três ou talvez quatro décadas, uma ênfase muito intensa. Em tais áreas existem bibliografias enormes, institutos de pesquisa, arquivos, cursos e até cátedras universitárias específicas. No entanto, não tem havido uma atenção similarmente notável dedicada ao que eu designaria de uma 'história da sensibilidade', seguindo os passos de Lucien Febvre (1987). Nesse sentido, as tentativas têm sido um pouco esparsas, além de consideravelmente assistemáticas. Sei que serei compreendido em minhas dificuldades.

Um dos objetivos deste trabalho é transportar a atenção do leitor para o fato de que a sensibilidade que temos hoje - seja auditiva, tátil, gustativa, olfativa, visual - tem uma história e, especialmente, uma significação. Seguindo diversas 
pistas que os historiadores nos fornecem e sendo quase meramente um discípulo desses etnógrafos de nós mesmos (Lévi-Strauss, 1967), pretendo tornar bastante claro que nossos sensos estéticos, nossas reações à violência, nossos sentimentos de medo, nossos cuidados com saúde, nossas preocupações com higiene, com horários, com exatidão e cálculo, nossas preferências amorosas e sexuais, enfim, coisas que parecem tão familiares e naturais aos nossos olhos, não existiram sempre e têm por trás de si um passado rico em detalhes e em variações. O passado não está apenas no passado: ele constituiu nossa sensibilidade e continua de certa forma, como veremos, a ser presente.

A estratégia que empreguei para o tratamento deste assunto é a que considero a mais fundamental da antropologia: comparar e contrastar, tentar entender como o mesmo pode ser outro, como o familiar pode vestir a roupa do estranho, como o semelhante pode ser diferente e vice-versa. De modo bastante específico e voluntário, procurei priorizar o contraste, dando ênfase a tempos e circunstâncias em que as questões que estudaremos aconteceram de maneira diversa daquela a que estamos habituados.

Procurei conscientemente exagerar o contraste. Por meio dele - por cujo excesso poderei mesmo ser objeto de críticas, provavelmente justas - tentei situar como é a nossa sensibilidade atual. Esforcei-me igualmente por dar uma idéia de o que ela representa histórica e politicamente. Acontece que neste trabalho o contraste é também uma estratégia de comunicação com o leitor. Procurei, tanto quanto me foi possível, permitir que o contraste falasse por si e revelasse o que teria a dizer sobre nós. Pareceu-me que este seria o caminho mais seguro para chamar a atenção sobre algo que é tão familiar ao leitor, que correria o risco de não ser percebido. Mas esta observação se aplica também a mim. Eis mais ou menos o ponto que pretendi ajudar a resolver mediante o contraste: assim como o olho não se vê a si mesmo, nossa sensibilidade não é muito sensível a si.

Mas, por que razão sensibilidade? Não estaria eu incorrendo no erro de repetir o que já foi feito no âmbito da história das mentalidades ou das idéias? Penso que seja preciso uma palavra sobre isto. Não quero me envolver em uma discussão bizantina sobre nuances de conceitos, muito menos sobrecarregar o leitor com tal exercício. Todavia, é preciso lembrar, de início, que mentalidades e idéias não necessariamente coincidem com sensibilidade. Aquilo que os homens pensam (ou dizem que pensam) e o que sentem não se coaduna obrigatoriamente - seja-me permitido e desculpado lembrar esta obviedade.

Um exemplo rasteiro disso: se fizermos uma enquete sobre o que as pessoas pensam a respeito do racismo, chegaremos a um determinado resultado (nos meios liberais ou de esquerda, possivelmente repúdio ao mesmo). Chegaríamos ao mesmo resultado se, nestes mesmos meios, o objeto da pesquisa fosse o que as pessoas efetivamente sentem em relação ao contato corporal entre raças, sobre a alimentação em comum etc.? Questão análoga poderia ser levantada sobre a rela- 
ção entre os sexos, as regras de higiene, a tolerância com os deficientes físicos, o tratamento a filhos adotivos, a doação de órgãos, e assim por diante.

Impossível, todavia, quando se trabalha com sensibilidades, não estar trabalhando com mentalidades e idéias, ou mesmo com os macroprocessos econômicos e políticos. A diferença, aqui, não é tanto de objeto. Na verdade, é sobretudo uma diferença de estratégia de abordagem do tema. Nos grandes processos de decadência do mundo medieval, de conquista do Novo Mundo, de formação do reino capitalista, por exemplo, há as idéias, as mentalidades, mas também as sensibilidades. Parte do propósito deste trabalho será tentar mostrar que assuntos deste teor não são dissociáveis e procurar exibi-los como interdependentes, isto é, os mesmos entrelaçamentos tecem simultaneamente o gigantesco e o microscópico. Transitarei, assim, livremente, de um para outro, embora procurando, como esforço específico, privilegiar as dimensões da sensibilidade.

O ponto de partida será a Idade Média. Referencial, na verdade, em grande medida arbitrário. Como Lévi-Strauss (1970) sabiamente observou, todas as

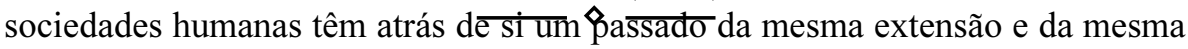
profundidade. Qualquer corte no tempo é, assim, algo arbitrário. Pensemos, apenas como ilustração, nos povos americanos. Não têm eles atrás de si um passado anterior à colonização, mais remoto que a Descoberta, ainda mais profundo que as migrações pelo estreito de Behring e que, no limite, como o passado de todos os homens, atinge o sul da África? Qualquer corte temporal, portanto, tem valor sobretudo estratégico. Não pode ser tomado como absoluto. De fato, poderia ter sido feito em quaisquer outros pontos - Grécia, Roma ou Antigo Egito - se esses fossem relevantes para o problema em estudo.

Não obstante, por seu valor estratégico, o corte que resolvi fazer neste trabalho também é em grande parte motivado. Em primeiro lugar, porque as mentalidades e as sensibilidades medievais são aquilo contra o que a cultura capitalista $\mathrm{e}$, mais adiante, a cultura industrial se definem. Estas culturas se posicionam diante da cultura medieval e afirmam enfaticamente para elas mesmas: isto é o que não queremos ser, isto é o que renegamos da maneira mais convicta e radical. De certo modo, a Idade Média constitui, se posso dizer assim, o outro específico da civilização moderna e contemporânea. E esta parte de nós, de nossa tradição cultural e histórica, que, paradoxalmente, no plano dos ideais, não cansamos de recusar, consiste, como espero demonstrar no fluir dessas linhas, em excelente referencial para contrastar e relativizar nossas próprias concepções e sensibilidades.

Encontramos em nossa cultura contemporânea uma relação, digamos assim, quase antagônica entre nossos sonhos, nossa maneira de ser, nossa sensibilidade, nossas atitudes, mentalidades etc., e seus correspondentes medievais. No que diz respeito à Antigüidade, até cultivamos uma certa afinidade idealizada. O Renascimento, por exemplo, valorizou a estética antiga; a legislação romana reapare- 
ceu com força no Estado moderno; a filosofia grega se transformou em referencial no Classicismo... Deste modo, se, por um lado, estou praticando um gesto arbitrário, por outro é possível presenciar, na escolha da Idade Média como ponto de partida, uma motivação estrategicamente relevante para o estudo que pretendo desenvolver. Espero que as páginas seguintes deixem este ponto inteiramente compreensível.

Em segundo lugar, um assunto mais polêmico: a escolha da Idade Média como ponto referencial de minha reflexão sobre a sensibilidade hodierna não se revela totalmente imotivada, simplesmente porque nas sociedades industriais contemporâneas há muito de medieval. Este traço é especialmente verdadeiro se tivermos em mente aqueles segmentos habitualmente chamados de 'pobres' ou de 'classes populares'. Como as páginas seguintes deixarão fortemente sugerido, estas serão, sem dúvida, as últimas a abandonar os padrões de comportamento, pensamento e sentimento que existiam antes da emergência do capitalismo. De maneira implícita ou explícita, deverei retornar diversas vezes a este aspecto.

Em terceiro lugar, gostaria de observar também que há muito de medieval na cultura brasileira (DaMatta, 1993a,1993b), embora não seja este um tema privilegiado do presente trabalho. Bastaria lembrar, sobre isso, que o País foi colonizado por portugueses e que Portugal, à época da colonização, não era vanguarda do capitalismo europeu. Dos portugueses que para cá vieram, em particular, não se pode afirmar enfaticamente que constituíssem, em sua maioria, a linha de frente do capitalismo português. Os colonizadores aqui aportaram ainda, e em muito, embebidos de uma visão de mundo anterior à cultura capitalista, que na época era apenas emergente na Europa.

Esta característica cultural dos colonizadores não será desprovida de conseqüências para matizar em muito nossas sensibilidades atuais no Brasil, notadamente naquilo em que discrepam, em todas as camadas da população, do que se observa nos países do Primeiro Mundo. Ela imprimiu sua marca em nossas sensibilidades, assim como o fez no vocabulário das classes populares, nas nossas festas folclóricas, na literatura de cordel, nas nossas crenças religiosas, nos nossos hábitos alimentares, nas nossas práticas cotidianas.

Em muitos momentos, escrevendo sobre a cultura medieval, tive a impressão cristalina de estar passeando pelas nossas cidades e, sobretudo, pelas nossas favelas, pois no Brasil ou na Europa, para retomar uma citação de Stubbs (The Constitutional History of England) feita por Alan Macfarlane (1989:199), "conforme descemos na escala social, a diferença entre a vida moderna e a medieval vai rapidamente diminuindo". Tal presença, na sociedade brasileira, não cessa de contaminar, diga-se de passagem, até mesmo setores bastante adentrados no universo moderno e industrial. Acho que o leitor terá, aqui e ali, sensação análoga.

A cultura brasileira é, em medida considerável, ante e anti capitalista, como costumo dizer. Semelhante afirmativa, talvez exagerada, será fácil de entender e de confirmar se considerarmos que aqui o capitalismo lançou bases firmes praticamen- 
te apenas nas regiões que receberam imigrantes já razoavelmente doutrinados em uma cultura capitalista. Foi mais ou menos o caso dos alemães no Sul e, de certa maneira, dos italianos em São Paulo. $\mathrm{O}$ argumento adquire muito mais força e se torna mais enfático se não nos limitarmos a considerar apenas a faceta européia de nossa constituição e se trouxermos à cena nossos personagens indígenas e africanos, quase unanimemente adversos à cultura que os vem escravizando e dizimando.

Para fazer essa viagem à Idade Média é preciso tomar alguns cuidados. Gostaria que antecipadamente me desculpassem os leitores dispensados de alerta em relação a esses aspectos. Aincta asş̂m, considerei prudente tornar explícitas algumas armadilhas que estão à espreita e que certamente poderiam inviabilizar nosso raciocínio de maneira perversa, transformando o nosso ponto de partida estratégico em um pântano em que nos faríamos inadvertidamente afogar.

Primeiro, mas não em ordem de importância, tomemos cuidado com as generalizações. Estamos sempre ameaçados pela tendência a acreditar que o outro seja homogêneo. Com facilidade dizemos: 'na cultura chinesa...' - e esquecemos que aí dentro figura cerca de um quarto da humanidade, um verdadeiro oceano de experiências e de diferenças, algo muito maior do que se poderá algum dia vir a conhecer. Analogamente, um cuidado fundamental é lembrar, inclusive para compensar liberdades que adiante tomarei, que a Idade Média não é homogênea e que sob este rótulo abrigamos, para dela fazer abstração, uma imensa multiplicidade de regiões, de povos, de grupos e também de classes sociais. Há ainda, sob o termo, uma pluralidade de tempos, pois esses mil anos que constituem a história medieval não se limitaram absolutamente a reeditar de maneira monótona o mesmo texto.

É importante, em especial como antropólogo, registrar esse cuidado com a generalização ou com a atribuição de homogeneidade ao outro. É bastante comum, na mitologia dos antropólogos, situar o nascimento da antropologia na descoberta do Novo Mundo. Segundo esse mito de origem, os homens teriam vivido acomodados a uma espécie de monotonia cultural antes e principalmente durante a Idade Média. Repentinamente, com a descoberta dos povos americanos, ter-seiam despertado uma súbita consciência da diferença cultural e uma curiosidade particular, anteriormente inexistentes. Cita-se, a este propósito, Montaigne, particularmente em seu conhecidíssimo ensaio sobre os canibais, como se ele fosse precursor de um novo saber dedicado à diferença, como se representasse uma espécie de pai fundador do raciocínio propriamente etnológico.

De fato, algo muda por esta época no que diz respeito ao entendimento da diferença. Sem embargo, do ponto de vista factual, essa idéia de que a diferença fosse desconhecida está totalmente equivocada. Como Marc Bloch demonstrou com toda clareza em seu importante trabalho sobre a sociedade feudal (1968), a Europa da Idade Média dista muitíssimo da paisagem de semelhança que o raciocínio supõe: conhecia e traficava íntima e intensamente com a Ásia, relacionava- 
se com toda a Europa do Norte, mantinha contatos freqüentes com a África, especialmente com o norte muçulmano, além de ser ela mesma um gigantesco caldeirão de índoles, de crenças, de religiões, de povos, de destinos, enfim.

A diferença obviamente não nasceu com as grandes navegações ou com o descobrimento da América. Aquilo que mudou - mas por outras razões que não as grandes navegações ou as grandes descobertas - foi a atitude diante do outro. A atitude de tentar compreender o outro como objeto e a postura objetificante ao explicálo é que encontram um nascedouro mais ou menos por essa época. Mas essa atitude de tornar o outro objeto é também, de certa maneira, um procedimento de negar o outro enquanto tal. No limite, ela quer domesticá-lo, privá-lo de sua alteridade selvagem, reduzir suas ações às próprias, capturar e fazer devorar sua lógica pela do sujeito. É necessário que nos precatemos, portanto, contra essa tendência etnocêntrica ao empobrecimento semiológico da Idade Média - procedimento que consiste em desqualificá-la para, sobre esta desqualificação, fundar a ilusão de superioridade do conhecimento que pensa poder abarcá-la.

Ainda nesta direção, é preciso, em seguida, afastar alguns preconceitos. Afirmei anteriormente que a Idade Média é aquilo contra o que o capitalismo simbolicamente se definiu. Na visão de mundo deste sistema, aqueles séculos constituiriam uma espécie de território de barbárie, noite de mil anos, floresta de pedra, idade das trevas, período da história em que nada ou quase nada culturalmente relevante teria acontecido. Tempo em que tudo o que fosse virtude pelo prisma das idéias capitalistas simplesmente inexistiria. Época em que todas as 'conquistas' do futuro permaneceriam ausentes.

Antes de tudo, devemos ver nessas opiniões uma atitude política. O sistema capitalista nasceu, como sabemos, da ruptura das relações sociais, políticas e econômicas medievais e se definiu por antagonismo a estas. Muitos dos epítetos que se lançam contra a cultura medieval têm raiz exatamente nesse enfrentamento - que é globalmente simbólico, mas ao mesmo tempo político e ideológico: os preconceitos decorreriam automaticamente de o medieval ser o diferente específico do capitalismo adiantado; seriam a própria concretização dessa alteridade particular, travestida de conhecimento.

Notemos, primeiramente, com Umberto Eco (1989), que a própria idéia de Idade Média é uma noção residual. É necessário tê-lo sempre em mente: quando alguém fala em Idade Média, refere-se a algo que não sabe muito bem como situar entre duas Idades, ou duas Eras, digamos, 'ilustres'. De um lado, a Antigüidade, tendo toda positividade e sempre existindo com pleno e todo direito. De outro, as Idades Moderna e Contemporânea, que são os tempos do capitalismo, da Revolução Industrial e do progresso - também considerados pelos teóricos, historiadores, pensadores políticos, bem como pelo senso comum, com positividade em si. Entre elas figura alguma coisa ambígua, que se chamou de 'média': tempo não definido por qualquer positividade. 
Ao contrário, até: em geral a Idade Média é definida pelo negativo. Chamar algo de antigo, em grande medida é chamar de 'clássico'. Qualificar de moderno é elogiar e despertar orgulho. Mais ainda é adjetivar de pós-moderno. Referir-se, porém, a algo ou alguém como medieval é quase como utilizar uma categoria de acusação, uma vez que esse tempo passou a ser considerado como a época dos bárbaros, como a Idade das Trevas, como a noite de mil anos... Ela nada tem daquela Antigüidade, pela qual temos certo respeito e nostalgia. Nada apresenta da Modernidade, em relação à qual nutrimos profundo sentimento de glória e mesmo de orgulho. Nada disso. Exceto no círculo restrito de poucos especialistas - e, ainda assim, somente desde tempos muito recentes -, para a Idade Média cabem somente as acusações mais preconceituosas. Obviamente não nos deixaremos surpreender por esta armadilha que o etnocentrismo nos prepara.

Depois, encontramos aí uma questão teórica crucial, fonte de muitos enganos e preconceitos contra o mundo medieval. Esta questão decorre do fato de pensarmos viver em uma sociedade que progride, que evolui, que se desenvolve, que busca metas e está sempre crescendo na direção de um estágio social aperfeiçoado. Concebemos a história, em conseqüência, como uma sucessão de degraus progressivos, avanços, realizações, conquistas em relação a estágios antecedentes e que nos levariam à perfeição da sociedade futura. Seria bom que tomássemos prudente distância relativamente aos perigos embutidos nessa concepção de tempo e de história.

No plano específico da história ocidental, esta concepção reproduz o modo mais geral pelo qual, muitas vezes, teóricos, ideólogos e senso comum encararam a própria trajetória da sociedade humana. Quem, dentre nós, não ouviu pelo menos uma vez a história que narra como, no início dos tempos, os homens foram seres subjugados pela natureza, hostilizados pelo mundo? Nessas concepções, os homens são invariavelmente apresentados como seres frágeis: não possuíam a garra de certos animais, a força de outros, velocidade ou resistência comparáveis... O homem vivia nos primeiros tempos como um pobre-coitado, apanhando do mundo e sendo sacrificado. Não obstante, era dotado de inteligência - faculdade que pôde materializar em ferramentas, instrumentos. Com inteligência e ferramentas, o homem, segundo tal teoria, começou a reverter o quadro inicial. De escravo da natureza, foi-se progressivamente transformando em senhor dela. Cada passo da história da humanidade passou a ser uma vitória do homem sobre o mundo e sobre si mesmo.

Todos já ouvimos essa narrativa em algum lugar: no cinema, nos livros de antropologia, nos museus, na página um dos manuais de desenvolvimento econômico. Essa teoria, que é na verdade o mito de origem da sociedade industrial, conta como a ciência e a tecnologia, pilares desta sociedade, são importantes e legítimas. Narra como a maneira de viver baseada na ciência e na tecnologia é intelectual- 
mente necessária, além de emocionalmente desejável. Procura seduzir e convencer.

Não pretendo estender-me sobre este assunto, que já mereceu minha atenção em outro lugar (Rodrigues, 1989). Quero registrar, entretanto, que os percursos atuais da pesquisa antropológica tornam tal narrativa bem pouco verossímil. Em primeiro lugar, não há qualquer razão de ordem ecológica para que se aceite essa teoria baseada no pressuposto de uma miséria original. Afinal, toda espécie vive em ambiente propício à singularidade de sua vida. Espécie inadaptada ao próprio habitat simplesmente não existe: seus grupos migram ou desaparecem. Por que razão os homens seriam os únicos cronicamente inadaptados a seu mundo? Por que seriam eles os solitários seres fadados a não se sentir em casa, os alvejados pela hostilidade de seu próprio ambiente?

O raciocínio sobre dados arqueológicos, ademais, vem demonstrando cada vez mais claramente que esse ser humano primordial não vivia absolutamente à míngua. Até onde se pode ir no tempo, os materiais arqueológicos são surpreendentemente numerosos e de tipologias múltiplas, apesar da grande dificuldade de conservação que os milênios suscitam. As sepulturas contêm alimentos, os ossos muitas vezes são decorados, o que quer dizer que esses homens praticavam ritos e não eram seres exclusivamente movidos pelo estômago. A propósito, pergunte-se de passagem: que vivente à míngua poderia se dar ao luxo de oferecer alimentos a defuntos?

Existem ainda os estudos etnográficos (Lizot, 1980) sobre sociedades atuais de caçadores e coletores, demonstrando que vivem muito longe de uma suposta penúria, longíssimo de uma alegada miséria original. Ao contrário, contestando radicalmente um raciocínio de índole evolucionista, em geral são os agricultores (que, segundo esta teoria imagina, constituem um passo além na evolução social em relação aos caçadores-coletores) os que costumam ser mais maltratados pelo mundo e escravizados pelo trabalho. Por analogia - e inesperadamente para essa teoria da miséria original -, exatamente os caçadores da Idade da Pedra é que constituiriam o que Marshall Sahlins (1974) irônica e provocativamente designou de "a primeira sociedade de abundância".

Há finalmente um ponto definitivo para os nossos propósitos. Quando se imagina que a história seja progressiva, evolutiva e que cada passo seja uma conquista na direção de determinadas metas, obrigatoriamente se imagina também que tudo o que for conseguido no último estágio deverá ser inexistente nos primeiros tempos, ou, no máximo, existente de modo apenas rudimentar (Clastres, 1980). Assim, se fabulamos que a história da humanidade deverá chegar ao homem que domina o planeta, certamente essa narrativa deverá começar pelo homem subjugado por este. Se essa 'estória', por meio de múltiplas conquistas, deságua em uma sociedade rica, claro está que no começo é a pobreza que reina; se atingirá as 'melhores' formas de relacionamento sexual, é evidente que no primeiro degrau haverá a promiscuidade primitiva... 
O núcleo do raciocínio é o seguinte: se esse degrau inicial nunca tiver existido, é preciso que seja urgentemente inventado, porque essa ficção é o que sustenta o edifício da história. Sem esse artifício, a construção dessa estória (ou história, tanto faz) implode. Toda teoria baseada nas idéias de progresso e evolução cai por terra, se não estiver sustentada por esse primeiro momento lógico-fictício.

Decorrência perfeitamente compreensível, essa teoria-mito autoriza hierarquizar homens e sociedades. Propõe a existência de homens que já teriam realizado mais total e plenamente a humanidade. Inventa homens totalmente homens, como nós, habitantes da sociedade industrial, plenamente senhores da ciência e da tecnologia, da razão e da ferramenta, por um lado, e, por outro, homens a meio caminho, ainda no início das conquistas, homens rudimentares, à espera de realizar plenamente a humanidade. Evidentemente, trata-se também de uma teoria de poder, um mito de legitimação a autorizar intervenções. Sugere implicitamente que é possível ir ao outro, com toda a licença, para tentar aniquilar sua alteridade, exibindo o argumento de estar a lhe levar uma humanidade de que é carente. Pelo viés dessa teoria, a intervenção se transforma magicamente em caridade: tira-se o outro do fundo do poço de sua ignorância e escravidão e se o transporta às luzes da humanidade plena.

A Idade Média dos preconceitos desempenha exatamente esse papel de degrau zero do capitalismo e do socialismo. É inventada, de certo modo, com o fito de nos convencer dos progressos representados pelo capitalismo sobre o feudalismo, do socialismo sobre o capitalismo, do comunismo sobre o socialismo... Independentemente de colorações políticas de direita ou de esquerda, quem acredita no mito do progresso teoria ou senso comum - deverá necessariamente fabular esse degrau zero, que é a Idade Média negativa. Isto porque tal é o contraponto lógico, político e ideológico do sentido de tudo o que será 'conquistado' pelo progresso. Encontramos aqui, por conseguinte, mais um sinal de alerta, fundamental para não viciar previamente o raciocínio que vamos desenvolver: controlar tanto quanto possível nossos ímpetos e inclinações progressistas, com o intuito de poder considerar a Idade Média em seus próprios termos.

Há ainda, nesta armadilha, um dispositivo muito sutil e imensamente importante, talvez a mais grave ameaça contra a qual nos precaver. Ao definir-se negativamente a Idade Média por aquilo que ela efetivamente não é, a acusação se fantasia de verossimilhança e adquire grande probabilidade de ser tomada por verdadeira, caso não se redobrem os esforços de atenção no sentido de contextualizar e relativizar as proposições que a materializam. Várias dessas proposições passariam perfeitamente por verídicas ou inquestionáveis, se não fossem puras negatividades; se não se limitassem exclusivamente a ser mera expressão do ponto de vista capitalista e industrial. Isto é, se não fossem essencialmente estranhas ao universo a que pretendem se referir.

Alguns exemplos tornarão essas palavras menos nebulosas. Imaginemos que se diga que a Idade Média não tenha produzido grandes pintores e compositores. Escorregaremos na constatação fácil, se não lembrarmos imediatamente que 
os critérios e temáticas estéticos eram outros. E que, dado o espírito comunitário do ateliê artístico medieval, a obra de arte não era considerada expressão de uma personalidade autônoma, sendo a grande inspiração justamente a cópia e a imitação dos mestres (Hauser, 1964; Chastel, 1991).

'Artista', aliás, é um termo inexistente ainda no Renascimento - se com ele pretendemos nos referir a um especialista que, isolado das guildas e corporações, trabalha sozinho em seu estúdio, para solitariamente produzir, com ofuscamento de seus colaboradores, 'a' obra que concebe sem a intervenção, a demanda ou a encomenda de outrem. Assim, é fácil compreender que o hábito de realizar ou assinar obras artísticas individualmente ainda não se tivesse alastrado com a força que viemos a conhecer depois da emergência da cultura individualista, e que pudesse mesmo passar, nos tempos medievais, por pecado de orgulho. As primeiras assinaturas, tímidas, tinham aliás um aspecto que nos pareceria bastante canhestro: "a obra que tu vês, Fulano a fez sabiamente", ou "Beltrano me fez" (Castelnuovo, 1989:256-257).

Embora no século XIII tenham aparecido os primeiros arquitetos, orgulhosos de si mesmos, respeitados, e assinando as obras com seus nomes (Duby, 1988b), era muito mais freqüente que o indivíduo negasse a autoria de uma música, recusando sua responsabilidade. Mesmo sendo o verdadeiro compositor, normalmente dizia que a ouviu de uma terceira pessoa (Burke, 1989). A Idade Média era um tempo em que os autores se copiavam em cadeia, sem qualquer preocupação de citar-se. Tempo em que a originalidade podia ser mal interpretada, aproximando-se do pecado de orgulho, como acabei de observar (Eco, 1988). Keith Thomas refere-se a um caso em que um arqueiro foi acusado de bruxaria, simplesmente porque atirava bem demais (1971).

Suponhamos também que se afirme que a Idade Média não tenha feito grandes progressos na direção de uma ciência inteiramente racional. Em âmbito geral, a afirmativa tem algo de verdadeiro, enquanto proposição factualmente absoluta. Não obstante, seremos induzidos a erro se não a relativizarmos, considerando que naquela época a separação entre sujeito e objeto de conhecimento não se tinha ainda completamente constituído, e que a atitude de olhar imparcial e objetivamente para o mundo, embora fosse uma possibilidade aberta aqui e ali, não era prevalecente na cultura, não era preocupação preferencial das pessoas, nem era valor particularmente apreciado. Nos saberes, nas técnicas ou nas artes, as mentes generalistas e polivalentes preponderavam sobre os especialistas, talvez ainda por nascer.

Ainda um terceiro exemplo. Quando se atribui à Idade Média incapacidade de acumular grandes riquezas e de investir, antes de tropeçar na obviedade factual do argumento, não deveríamos considerar que a acumulação capitalista não era um princípio cultural do medioevo, não constituía meta ambicionada daqueles tempos, e que em seu lugar existia uma ética presidida pelo prazer não adiado, pela consumação, pelo esbanjamento e pela distribuição? 
Assim como ocorreu com os povos primitivos ('sem' Estado, 'sem' classes, 'sem' escrita, 'sem' história etc.), é comum procurar-se caracterizar a Idade Média por ausências, ou seja, como um momento da história ao qual 'faltavam' traços que consideramos fundamentais. Ora, afirmar que uma árvore não é um pé de carambola, definindo-a, portanto, negativamente, é dizer muito pouco ou quase nada sobre ela. Do mesmo modo, ao acusar-se a Idade Média de não possuir algo semelhante à ciência, na verdade não se está propriamente falando da Idade Média: está-se tratando de algo muito importante para a cultura pós-renascentista, não para a medieval.

Por semelhante caminho, o raciocínio foge. Foge da positividade do medieval ao preferir abordá-lo pelo seu negativo, de modo estranho privilegiando nele exatamente o que nele não existe. Obviamente não iremos muito longe, tentando compreender macacos através da ausência de escamas. Porém o mais perigoso, em raciocínios deste teor, está na insídia da persuasão que aí reside, pois quem define a Idade Média por aquilo que efetivamente ela não é pode muito facilmente, em seqüência, convencer que a definição, assim como seus corolários, seja inteiramente correta. Raciocinando pelo negativo, corro o risco de me deixar seduzir, de me enganar por meu próprio raciocínio, de errar e permanecer no erro.

É importante também, preliminarmente, observar que a Idade Média que nos é mostrada com mais freqüência e por divulgação em larga escala - nos livros escolares, nos filmes de cinema e televisão, nas peças de teatro, na literatura de ficção, nos best-sellers, isto é, aquela Idade Média romanceada dos cavaleiros, das bruxas, dos carrascos, da Inquisição, da fome, das pestes, das torturas corresponde normalmente ao cenário final dos tempos medievais. Este retrato configura mais propriamente a fisionomia de uma sociedade em crise, o rosto de um sistema social, político e econômico que se defrontava dramaticamente com seus limites e que se encontrava em vias de transformação.

Carrascos, bruxas, torturas, pestes, pobreza etc. não são as figuras típicas da sociedade medieval organizada. Aparecem, do modo mencionado, como expressões da crise daquele tempo e têm um caráter político muito claro. Não se pode dizer com absoluta certeza se são atribuíveis ao passado e seu colapso, ou se devem-se à emergência do futuro e de seus novos poderes. Ocorre, entretanto, que esses fenômenos e personagens se acomodam muito mal à idéia que gostamos de cultivar sobre os progressos do capitalismo: compreende-se, então, a quase insensível e irresistível tendência, que é ao mesmo tempo teórica e ideológica, a empurrá-los para trás no tempo.

Não se trata, de modo algum, de propor que vários desses eventos e personagens não estivessem presentes na Idade Média. Todavia, é necessário fazer uma justa contextualização deles. Por exemplo: a bruxa existia, mas era personagem mais ou menos rotineiro e cotidiano. Seu lugar por excelência não era absolutamente a fogueira (Ginzburg, 1988). Existia como a sua vizinha e coexistia perfeitamente com esta. O Malleus Maleficarum, mais conhecido como o martelo das 
feiticeiras, de Heinrich Kramer e Jacob Sprenger, apareceu em Estrasburgo em 1487. Mesmo considerando-se que a perseguição às bruxas houvesse começado havia um século, não se trata de algo exatamente medieval.

O carrasco também existia, mas sua importância nem de longe é comparável à que veio a atingir no Século das Luzes e seguintes, quando foi até mesmo necessário inventar máquinas para racionalizar o seu serviço (Lecherbonnier, 1991). Com freqüência o verdugo não era alguém distinto do senhor local, que desempenhava papel semelhante ao de juiz, além do de executor de sentenças. Torturas igualmente existiam, embora o suplício da roda tenha sido introduzido na França em 1534, por Francisco I (Delarue, 1980). Ao lado disso, é preciso considerar que as torturas recebiam um sentido bem particular, no âmbito de concepções muito específicas sobre corpo e alma, sobre o significado da dor, do sofrimento e da salvação.

É claro que existe uma duração, digamos, 'oficial', da Idade Média, sobre a qual muita tinta já escorreu das penas dos historiadores. Evidentemente, não é com essa duração que estou conßidanto o leitor a trabalhar. Não é essa duração, essa cronologia da história convencional, o que interessa ao antropólogo, mais preocupado com grandes conjuntos significativos do que com encadeamentos de eventos. Na verdade, é uma Idade Média existente, por assim dizer, ao lado e fora da Idade Média oficial, uma Idade Média 'real', que nos ocupará (Le Goff, 1980). Colocarei todas as aspas do mundo na palavra 'real'. Mas com isso quero dizer que meu interesse se voltará para uma Idade Média que transbordou e ultrapassou em muito os limites fixados pelas datações oficiais, um medieval que permaneceu e que permanece, constituindo uma espécie de subsolo presente e atuante em nossa cultura contemporânea.

Trataremos, assim, de uma Idade Média que em grande medida remanesce como prática, como pensamento e como sentimento. Não apenas nas classes populares, inclusive nas dos países de capitalismo avançado e industrializado, como já destaquei. Estaremos lidando, nas páginas que se seguem, com algo ainda mais efetivamente presente, com uma permanência indelével, inscrita em filigrana no íntimo de nosso ser contemporâneo: enquanto nosso outro específico, o medieval, embora possa estar cronologicamente ausente, continua insistentemente presente como virtualidade atuante.

Fácil compreender: aquilo que não quero ser é parte 'inabstraível' do que sou; aquilo que uma sociedade renega é intimamente integrante de si. Falaremos, pois, de uma Idade Média que de certa forma não morreu. Que teve o seu grande momento, é verdade, talvez não sendo agora mais do que espectro. De uma Idade Média que passou, por assim dizer, do primeiro plano para uma espécie de bastidor. Mas o lençol d'água que ela constitui emerge com freqüência, sobretudo em momentos dramáticos da nossa política e da nossa psicologia - não raro provocando inundações. Parafraseando o historiador Pierre Nora (1984), ao evocar a 
Idade Média para entender a subjetividade contemporânea, de certo modo incentivo o leitor a buscar não uma gênese, mas uma decifração do que somos à luz do que pensamos que não somos mais.

Há uma Idade Média positiva. Para encontrá-la não é necessário fazer recurso a um princípio filosófico que recuse admitir que homens pudessem existir mil anos nas mais densas trevas, comro sesta fosse uma condição humanamente suportável. Também não é preciso recorrer à experiência dos antropólogos, que não registra sociedade que exista em semelhante situação. Basta simplesmente deixar que os fatos medievais falem por si. Por esse caminho, quando falarmos de medieval encontraremos, ao contrário, um grande crescimento de populações, um fervilhar de movimentos e de trocas entre tribos e povos que se cruzavam e interinfluenciavam. Descobriremos imensa dilatação dos espaços ocupados, homens se estabelecendo nos mais diversos pontos da Europa, vindos de fora e aí lançando raízes. Verificaremos enorme florescimento de cidades, dos pequenos burgos às grandes aglomerações. Saberemos das grandes viagens para a Ásia e África, das aventuras de pessoas que foram longe e que retornaram com idéias e imaginários enriquecidos e multiplicados. Visitaremos catedrais, castelos, fortificações, grandes prédios que são obras de arte, sínteses de uma visão de mundo, obras nas quais não há um milímetro em que não se possa ver a concretização artística dos usos, das concepções, do imaginário sagrado ou cotidiano.

Não obstante, não será este lado monumental da Idade Média que nos irá ocupar para exibir sua positividade. Apenas seguiremos os passos de historiadores que, usufruindo da frutífera aproximação entre a antropologia e a história, procederam mais ou menos como etnógrafos, tentando dar uma resposta ao repto lançado por Braudel: "como sabem, os homens não comem nem bebem nos livros de história tradicional" (1987:17). Estes historiadores, dos quais estudos específicos mencionarei no decorrer da exposição, são viajantes que, em vez de se locomoverem no espaço, se deslocaram no tempo, indo a outra sociedade para compreendê-la em si, positivamente, fazendo esforço para registrar o banal, o cotidiano, as pequenas coisas do dia-a-dia.

Como era fabricado o pão? Como era o forno em que este era assado? Qual a sua localização? Quem tinha acesso a ele? Como eram as relações sexuais? Quem tinha acesso a quem? Que posições? Com que finalidades? Como as pessoas se vestiam? Existia diferença entre roupa de homem e de mulher, de criança e de adulto, vivos e mortos? Com que periodicidade se trocavam as roupas? Com que finalidade? O que se comia? Como se preparavam os pratos? Com que aspecto eram apresentados? Como eram apreciados? Talheres existiam? Quais? Como os doentes eram tratados? Onde ficavam? Que medicamentos usavam? Como se concebiam as doenças? O que se fazia com quem morria? Como eram as exéquias? E a convivência - se é que existia - entre vivos e mortos? Qual o valor da vida? 
Evidentemente, não será minha a tarefa gigantesca de responder a todas essas perguntas. Cito-as fundamentalmente com intuito de ilustrar um esforço, um tipo de preocupação, um modo de olhar que consiste em colocarmo-nos, de certo modo, na posição de um existente daqueles tempos e, desse ponto de vista, tentar compreender coisas tão 'ínfimas' como o olhar, o olfato, o paladar, o tato, a sensibilidade auditiva, as etiquetas, os prazeres, os desprazeres...

De nossa parte, este esforço requer um grande cuidado, sobretudo para evitar o anacronismo etnocêntrico de imaginar que os nossos comportamentos, pensamentos e sentimentos sejam os 'do Homem' e que possam ser, conseqüentemente, projetados sobre os tempos medievais. Requer também um pouco de coragem. Assim como é necessário ao etnógrafo ter a ousadia de sair do conforto de sua casa, viajar às vezes milhares de quilômetros em circunstâncias adversas, para viver em meio a pessoas que sentem e pensam de um modo completamente diverso, ser-nos-á necessária alguma intrepidez: o destemor de abrir mão de nossa sensibilidade burguesa, para tratar de temas - fezes, lixo, sangue, morte - que, por sensibilidade burguesa, normalmente estão afastados de nossa preocupação intelectual.

Na primeira parte deste trabalho, tentarei esboçar um panorama geral da Idade Média, especialmente no que diz respeito às características mais marcantes de sua cosmovisão - vida, mo, espírito, matéria, indivíduo, sociedade... Começarei a colocar algumas primeiras idéias, muito amplas, que nos servirão de ponto de apoio para alçar vôo, seguir trilhas e tentar fugas razoavelmente específicas na direção da sensibilidade medieval e seus desdobramentos. Esta primeira parte é estratégica para realimentar ou dar inteligibilidade ao raciocínio. De modo explícito ou implícito, convidarei constantemente o leitor a retornar a esta base, ou campo de pouso, no curso dos capítulos da segunda parte. 


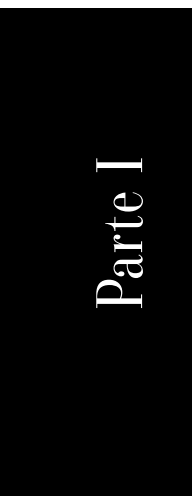




\section{1 \\ Antes e Depois?}

Proponho uma viagem estacionária. Começaremos tateando, desde o mais geral, tentando destacar alguns fundamentos, alguns princípios de uma organização possível, princípios que nos permitam penetrar na cultura medieval e sair dela enriquecidos. Evidentemente não terei como fazer uma etnografia completa da Idade Média: não tenho tal capacidade, nem é este o objetivo. Apenas procurarei colocar em evidência algumas práticas e crenças, selecionadas voluntariamente em função de meus propósitos. Com base nelas, tentarei depreender padrões gerais a que recorrerei com freqüência, em busca de inteligibilidade a respeito do que fluiu a partir desse tempo. Buscarei, embora precárias, algumas estruturas de pensamento que atribuíam significação aos agires e sentires dos seres humanos de então, e que continuam embutidas em nossos existires. Como "o passado não está apenas no passado", para lembrar as palavras de Jacques Le Goff (1985:219), pretérito e presente formarão para nós uma espécie de globalidade única, em que o antes e o depois coexistirão de maneira tensa, antagônica e cúmplice.

Sob um vocábulo singular, estaremos abrigando artificialmente numerosíssimos plurais. O longo medieval, que pôde ser datado "a partir do segundo ou terceiro século de nossa era" (Le Goff, 1980:11), nada tinha do sombrio silêncio que nele viram os humanistas do Renascimento, os iluministas do século XVIII ou os crentes nas religiões do progresso, dos séculos seguintes. Nada de estagnação, absolutamente: a Idade Média constituiu os séculos em que germinaram - ainda que paradoxalmente e em muitos casos para parasitá-la e corroê-la coisas absolutamente fundamentais no que diz respeito à edificação da modernidade (Gimpbel, 1976): a nação, o Estado, a universidade, a máquina, o relógio, a contabilidade, a divisão do trabalho, a individualidade...

Não é este todavia o seu lado intrinsecamente mais rico. A Europa medieval foi uma efervescência de movimentos, migrações, batalhas, trocas, comércio interpenetrações que se materializaram, ora na sucessão, ora na contemporaneidade, em misturas de elementos inteiramente díspares. Em primeiro lugar, os vários grupos que, desde tempos imemoriais, povoavam aquele território, gente precedente e às vezes resistente à expansão romana: os lusos, os bretões, os bascos, os 
gauleses, os frísios, os batávios, os saxões, os aquitães... Em seguida, a conquista de parte significativa desses grupos nativos, itálicos, ibéricos, célticos, e sua romanização - quase nunca inteiramente consumada. Em terceiro lugar, a invasão desse universo, dessa conjunção romanizada, pelos chamados bárbaros germânicos, eslavos, árabes... novas tribos que se vieram adicionar a uma paisagem cultural já sensivelmente heteróclita. Nos prenúncios dos tempos medievais, a Europa era, assim, um continente cujo conteúdo configurava uma extraordinária diversidade cultural: cada um desses povos tinha suas tradições, línguas, religiões, rituais, mitologias, culinárias, organizações sociais...

Ao mesmo tempo - quarto e duplo movimento - esse grande caleidoscópio de diferenças se expôs, nos séculos propriamente medievais, à pressão de duas forças que o pretendiam homogeneizar e unificar. A lei do antigo Direito Romano, essencialmente imperial, por um lado, tentando se impor muito lentamente, com o Estado. O catolicismo universalista, por outro, aspirando obsessivamente a converter, não obstante se defrontasse com toda sorte de resistência por parte das populações bárbaras ou pagãs, com as quais desde os primeiros tempos e ainda por muitos séculos foi obrigado a conviver, em muitíssimos casos fazendo concessões. Desses dois movimentos homogeneizadores, o catolicismo é, sem dúvida, o mais crucial para entrarmos no universo da Idade Média. O Estado, talvez, o mais significativo para dele sairmos.

Especialmente na Europa ocidental, a Igreja foi a única instituição realmente poderosa e universal, sobretudo depois da queda do Império Romano. Sobre as circunscrições administrativas do império, a Igreja decalcou as religiosas. Por exemplo, cada diocese católica correspondia em geral a uma civitas romana (Pirenne, 1964). Na Idade Média, fazer parte da Igreja era uma escolha voluntária apenas em teoria: muito ao contrário, e de maneira sempre mais e mais abrangente e incisiva, na prática a adesão religiosa talvez fosse a mais estritamente obrigatória das decisões de um ser humano medieval.

Isto valia não apenas para homens simples e comuns: mesmo reis e potentados tremiam diante da possibilidade ou da ameaça de serem afastados da Igreja. Esta era onipresente, quer como mosteiro, capela, catedral ou santuário. Reinava dos campos e das aldeias mais humildes às cidades mais importantes. Suas torres e campanários dominavam a paisagem longínqua e eram o que primeiro os viajantes enxergavam. Em uma Europa caracterizada por admirável variedade de dialetos, leis, culinárias, moedas, padrões de pesos e de medidas, o catolicismo representava o único idioma partilhado universalmente: o mesmo credo, mesmos rituais, mesmas missas, celebradas pelos mesmos gestos, que eram encadeados segundo a mesma ordem.

Ainda que se considere o papel desse catolicismo unificador, falar em Idade Média no singular é referir-se a uma imensa abstração. Do ponto de vista da cultura, significa fazer uso de uma generalização transbordante, que trata como coisa única um verdadeiro oceano de diferenças, de contrastes recíprocos e respec- 
tivos. Estes contrastes recíprocos não se tornam semelhança senão pelo fato de, vistos de fora e de longe, serem genericamente considerados como 'outros', isto é, como 'diferentes de nós' - ou seja, como diferentes do nós posterior, do nós imbuído de catolicismo reformado, de capitalismo, de Estado, de individualismo... Deste modo, ao falar de Idade Média, no singular, estaremos trabalhando com um modelo extraordinariamente generalizador e, portanto, muito passível de aqui e ali ser desafiado e falseado por registros e informações empíricas que a ele não se ajustem. É bem normal que assim seja.

Contudo, nosso problema apenas começa aí, infelizmente. Não nos basta tomar precauções contra a tendência etnocêntrica de homogeneizar o outro, atribuindo-lhe, um excesso de semelhança, por meio de uma primeira generalização, ditada pelo nosso ponto de vista ideológico, determinado pelo Estado e pelo catolicismo. Realisticamente, nada, ou pouco, conseguiremos, do mesmo modo, se nos deixarmos afogar no mar das diferenças 'bárbaras' e 'selvagens', se nos permitirmos devorar pelo redemoinho insaciável das diferenças ilimitadas. Serei, por isso, obrigado, embora por razões distintas, a operar com uma espécie de segunda generalização. Por intermédio desta, tentarei atenuar o excesso de diferença, tornando-a manuseável e procurando dar-lhe uma forma mais ou menos organizada ou sistemática.

Respeitadas as limitações teóricas, empíricas e também políticas dessas grandes generalizações, pode-se dizer, simplificadamente, para organizar o pensamento, que coexistiam nos tempos medievais dois tipos de cultura, como Michelet, obedecendo ao belo estilo de sua pena, já havia registrado (apud Le Goff, 1980:29):

sentado à margem deste grande rio poético da Idade Média, diviso duas fontes diferentes pela cor de suas águas (...) duas poesias, duas literaturas: uma cavalheiresca, guerreira, amorosa; cedo esta se torna aristocrática. A outra, religiosa e popular (...).

Uma cultura, assim, 'oficial', aristocrática, que conhecemos razoavelmente bem. A cultura da corte, dos nobres, da Igreja - especialmente de seu alto clero, com sua liturgia e hierarquia. Era a cultura de língua 'culta', de quem sabia ler e escrever, de quem falava latim, que era uma espécie de idioma internacional dos intelectuais. Essa foi a cultura da arte considerada digna, preservável, que, por isso, chegou até nós. Cultura de quem tinha vocação cosmopolita e que voava nas asas expansionistas da romanização e da cristianização.

É muito importante registrar que aquilo que começou a se constituir aos poucos, a partir dos séculos finais da Idade Média, não foi apenas uma sociedade de corte aqui e outra ali. Foi uma aristocracia, uma elite, que abraçou toda a Europa ocidental, com seu centro em Paris, dependências em quase todas as demais aristocracias e com afloramentos em todos os outros círculos que arvoravam pertencer à boa sociedade. Tais pessoas, com o tempo, serão encontráveis 
particularmente no estrato superior da burguesia, mas também, em certa medida, em suas camadas médias. Os membros dessa sociedade multiforme falavam a mesma língua em toda a Europa: inicialmente o latim e o italiano, depois, o francês. Liam os mesmos livros, tinham os mesmos gostos, as mesmas maneiras e - com diferenças de grau - o mesmo estilo de vida, submetendo-se a uma convenção muito rígida de conduta, a uma grande formalidade quanto à moderação dos afetos e a uma regulação cada vez mais rigorosa das maneiras e da gestualidade.

Não obstante suas divergências políticas, que não eram poucas, e em que pesassem as numerosíssimas guerras que travavam entre si, essas elites orientavam-se quase unanimemente e por períodos mais ou menos longos na direção de um centro, que era Paris. A partir de um determinado momento, a comunicação entre uma corte e outra, isto é, no interior da sociedade formada pelas classes aristocráticas, tendeu a ser mais intensa do que a que existia entre os membros de uma corte e os outros estratos de sua própria região, especialmente as camadas populares. Uma expressão dessa tendência discriminatória encontramos na língua comum que as aristocracias falavam, independentemente da região em que vivessem - língua que era inacessível à população em geral (Elias, 1993).

O uso da língua latina na Idade Média (Burke, 1993; Bloch, 1968), cuja importância é bem conhecida, apresenta-nos uma rápida e boa ilustração do que essa primeira modalidade de cultura medieval configurava. Em primeiro lugar, herdado do Império Romano, o latim constituía o idioma oficial da Igreja Católica - papel que veio desempenhando até os nossos dias inclusive, nos documentos papais, nos tribunais eclesiásticos, nos sínodos, nas encíclicas, nas missas...

Sabemos ser bastante comum, em diversas religiões, que se utilize uma linguagem sagrada como marcador ritual de separação relativamente a pessoas, coisas e assuntos profanos. Por certo este era um dos aspectos do latim litúrgico e clerical. Em 1562, o Concílio de Trento ainda condenava as traduções da Bíblia para os vernáculos e proclamava ser anátema a sustentação de idéia diferente. Entretanto, não se deve desprezar que este lado ritual da utilização do latim pouco se deveria coadunar com a vocação expansionista e conversora do catolicismo. A esta tendência convinha, obviamente, dirigir-se ao grosso da população, expressando-se por instrumentos de longo alcance, capazes de romper fronteiras lingüísticas e culturais. Adiante veremos como a Igreja superou esta aparente contradição.

O latim caracteriza bem, em nossa história, os meios sociais que se querem universais, embora simultaneamente aristocráticos e distintos. Ele permaneceu quase sempre onde quis permanecer o elitista. Ao mesmo tempo, seu abandono, freqüentemente polêmico, foi normalmente defendido em nome de alguma bandeira de 'democratização'. Assim, paradoxalmente, foi em latim que Erasmo clamou pela divulgação da bíblia aos grandes públicos, advogando a tradução nos diversos vernáculos. Foi ainda nessa língua que geralmente 
se expressaram os que escreveram até fins do século XVII. Galileu, Descartes, Bacon, Hobbes, Locke, Newton produziram em latim, salvo excepcionalmente. Montaigne o teve como sua primeira língua.

Nas universidades, durante quase toda a história, foi em latim que se falou e, sobretudo, que se registraram os conhecimentos. Ainda nos últimos anos do século XIX, autores como Bergson, em1889, e Durkheim, em 1892, apresentaram em latim suas teses de doutoramento ou, pelo menos, algumas partes delas. É nesse idioma, já em pleno século XX, que se aprendem as classificações zoológicas e botânicas, que se formulam os remédios, que se estuda Direito, que se milita parcialmente na profissão jurídica e que se oficiam trechos de alguns ritos, como formaturas e homenagens universitárias. Passando do 'alto' ao 'baixo', também é essa a língua que freqüentemente se utiliza para fazer referência àquilo que causa constrangimento se mencionado em linguagem habitual: daí expressões como membrum virile, coitus interruptus, vagina dentata etc.

A cultura de elite extrapolava, como se vê, as particularidades locais e regionais. Transcendia tanto o espaço quanto o tempo. Alimentava-se de lendas e textos da Antigüidade clássica, bem como dos mitos cristãos relativamente recentes. Seus estabelecimentos fundamentais eram as cidades, os castelos, os conventos, os mosteiros e as catedrais. Especialmente - e de interesse particular para os nossos propósitos no presente trabalho - nessa cultura já se podiam encontrar os gérmens da 'decência', da 'diligência', da 'gravidade', da 'modéstia', da 'ordem', da 'prudência', da 'razão', do 'autocontrole', da 'sobriedade', da 'frugalidade'... Ela constituiu o terreno, no qual já estavam lançadas as sementes daquilo que Max Weber mais tarde viria a celebrizar na tradição das ciências sociais, servindo-se da expressão "ascetismo mundano". Indispensável registrar: essa cultura, associada aos dominantes, só se tornou relevante por volta do século IX.

Até então prevalecia, quase sozinha, uma cultura cujas características gerais em grande parte se contrapunham, de modo quase antinômico, às que acabei de desenhar. Trata-se de uma cultura predominantemente pagã, cujos princípios discrepavam dos do cristianismo e cuja inspiração nada, ou muito pouco, tinha a ver com a cultura clássica. Esta outra era uma cultura ligada aos ritos e aos mitos pagãos, a uma visão de mundo ingênua, espontânea e sinceramente entregue a crenças e práticas mágicas. Era um universo em que se falavam os patoás, os dialetos locais, em que se empregavam falares que às vezes eram de aldeia, às vezes, regionais - raramente indo além dessa escala mais ou menos pontual. Trata-se de um universo que cultivava suas próprias mitologias ancestrais, seus ritos particulares e diversificados. Os costumes provêm das velhas tribos que precederam ou que invadiram o Império Romano. São práticas e crenças que carregam em si origens longínquas, que se devem a povos preexistentes ao cristianismo e ao Estado. E esta é uma característica de todo fundamental para o entendimento dos fatos que adiante analisaremos. 
Tal cultura tem base na tradição oral, nas transmissões diretas de geração a geração. Edifica-se, sobretudo, na efervescência inflamada da convivência social e na dramatização da vida cotidiana. Sua localização: nas casas, nas ruas, nos mercados, nas tabernas, nas estalagens, nas praças, nas rinhas de galos, nas rodas de jogos, de música ou dança, nas igrejas paroquiais. Enfim, uma cultura materializada nos lugares e nos tempos em que a vida se dava, em que as coisas aconteciam. Mesmo quando presente nas cidades, essa cultura - a do homem cotidiano da Idade Média - era de coloração fundamentalmente camponesa: de caçadores e agricultores, de homens diretamente relacionados com o mundo dos animais, das plantas, dos ventos, das chuvas, das temperaturas, das estações, dos astros...

A esta cultura do homem cotidiano costuma-se dar o nome de popular. Não vejo grandes razões para implicar com tal designação, já de certo modo consagrada nos meios acadêmicos e fora destes. No entanto, talvez seja necessário observar que o termo carrega um quê de anacrônico, quando remetido ao contexto medieval. É que, rigorosamente, a idéia de povo não fará sentido pleno senão em períodos históricos bastante posteriores - por volta ou a partir do século XVIII -, quando a separação entre povo e elite ter-se-á configurado com bastante nitidez, e quando as fronteiras entre as várias culturas do povo e as culturas de elite (também variadas) terão começado a ser mais significativas do que as relações e interpenetrações que apresentavam.

É importante ressaltar que, no contexto medieval, isto que depois se chamou de 'popular' era em grande medida a cultura de todo mundo. Naquele tempo, a elite participava vigorosamente da cultura de todos e era de certo modo bicultural: o padre que falava latim, falava também o patoá de sua região (aspecto importante para a divulgação do catolicismo); o nobre que vivia em castelo conhecia igualmente as tradições populares e delas tomava parte; o senhor honrado em sua culminância era também personagem das festas folclóricas, conhecia as mitologias locais, das quais era muitas vezes um figurante central; o leitor culto lia, quase sempre em voz alta, para um público que continha pessoas mal alfabetizadas ou analfabetas, os mesmos textos e os mesmos livros que circulavam em todos os meios sociais (Chartier, 1995); até mesmo o doutor da universidade era "exatamente o contrário do homem de gabinete, do pesquisador solitário" (Verger, 1990:65).

Os membros da elite conheciam canções e histórias populares, cultuavam relíquias e imagens devotas, participavam das festas de santos, dos festivais sazonais, do natal, do carnaval, dos solstícios... Mascaravam-se e cometiam saliências carnavalescas, divertiam-se com palhaços, tanto nas cortes como nas tavernas. Regozijavam-se com as touradas, com os açulamentos de cães e ursos, com as rinhas de galos. Mais tarde, deliciaram-se, como citadinos e camponeses, com os romances de cavalaria. Clientes, os curandeiros possuíam em todos os pavimentos da hierarquia social. Até mesmo o clero participava da cultura popular: frades jogavam bola, encenavam comédias, dançavam e tocavam instrumentos. Esses religiosos, normalmente filhos de artesãos ou campo- 
neses, com mais freqüência ainda eram biculturais, transitando da universidade à praça e ao mercado. Registre-se que este traço foi uma arma importantíssima para a estratégia de conversão que a Igreja viria a empregar.

Em síntese, cultura de elite e cultura popular não se opunham totalmente nos tempos medievais, nos quais as contradições eram mais horizontais (por exemplo, entre corporações, cidades etc.) que verticais (como entre classes sociais dominantes e dominadas, ricos e pobres, mestres e aprendizes). Pelo menos estas culturas não se ojerizavam, antes do final do século XVI, no mesmo sentido em que vieram a se antipatizar a partir da Idade das Luzes até os nossos dias. Até então - e ainda por muito tempo, em particular nas camadas inferiores, mas não somente -, os mitos e, principalmente, os ritos cristãos se misturavam com os das tribos bárbaras. As línguas românicas se mesclavam cada vez mais com as invasoras. O lugar onde se vivia era partilhado por múltiplas culturas (perigosa e artificialmente reduzidas aqui a duas), que confluíam e se misturavam nos seres humanos. Convergiam nas pessoas, embora se contradissessem nos princípios e na inspiração.

Até o século XVI, o que se encontra é imbricamento, amálgama, não oposição entre estas duas culturas. Durante séculos, os cenários públicos - igreja, taverna, praça do mercado - eram comunitariamente usados para todos os propósitos, laicos ou religiosos, festivos ou graves, ostentosos ou humildes, apesar das objeções repetidas (e isto, obviamente, por serem pouco respeitadas) do alto clero, católico e posteriormente protestante (Burke, 1989). Mistérios eram encenados abertamente. $\mathrm{O}$ adro das igrejas era usado para danças e banquetes. Nas vésperas das festas dos santos padroeiros, ricos e pobres, homens e mulheres, adultos e crianças, passavam as noites a comer e a beber, a cantar e a dançar, assumindo as mesmas atitudes íntimas com o sagrado e o mesmo estilo imoderado. Atitudes e estilo que nos pareceriam hoje totalmente exagerados e, em grande medida, incompreensíveis.

Esta cultura de todos existiu de modo pleno até por volta de 1500. Ao lado dela, desenvolvia-se pouco a pouco uma cultura para os instruídos - processo que se verificou por toda a Europa, em ritmos diversificados, embora aumentando o fosso sempre e inexoravelmente. Em 1800, na maior parte do continente, o clero, a nobreza, os profissionais liberais, os burgueses, já haviam quase completamente abandonado às classes subalternas aquela cultura que outrora pertencera a todos. Destas últimas, as elites se queriam, agora e doravante, dramaticamente separadas - distanciadas criticamente, afastadas por visões de mundo totalmente incompatíveis, como não havia acontecido anteriormente na história ocidental.

'Povo', nesses novos tempos, passou a significar outra coisa. Não mais 'todos', ou 'gente'. Mas 'simples', 'humilde', 'pobre', ou mesmo 'eles'. No terreno da religião, por exemplo, até 1500 a maioria dos pastores sempre fora da mesma origem cultural de seus rebanhos. Os reformadores introduziram modificações nesse panorama, para eles promíscuo, almejando de ora em diante um 
clero 'culto': mais do que os católicos, os sacerdotes protestantes tenderam a ser universitários de formação; todavia, mesmo entre os primeiros, os seminários foram cada vez mais se multiplicando, especialmente depois do Concílio de Trento.

Assim, o pároco que dançava, que se mascarava, que fazia piadas no púlpito, foi substituído pelo sacerdote sério, educado e distante. Os nobres começaram a adotar maneiras mais 'polidas', estilos mais autoconscientes de comportamento. Passaram a cultivar o autocontrole, as posturas corporais estudadas e artificiais. Abandonaram o hábito de comer misturados a seus dependentes, retirando-se para salas de jantar separadas. Deixaram de lutar corpo-a-corpo com seus camponeses. Aprenderam a falar e a escrever 'corretamente', segundo regras formais e de acordo com gramáticas normativas. Procuraram, enfim, marcar diferenças por todos os meios. Como se não bastasse esse movimento socialmente localizado, as elites tenderam a ser imitadas pelos meios sociais adjacentes, isto é, por aqueles que pretendiam fingir-se de nobres - mesmo com todos os ridículos que normalmente acompanham essas situações.

A nova cultura aos poucos se retirou e começou a viver separadamente nos castelos, nas universidades, nas bibliotecas, nas escolas, nas catedrais. Não apenas se afastou: passou a segregar. Em grande medida passou a desprezar e detestar a antiga cultura tradicional que, no entanto, continuava existindo e sendo atuante para a maioria da sociedade. Essa antiga cultura, agora 'folclórica', transformou-se em objeto de rejeição e ao mesmo tempo de interesse fascinado e algo mórbido (etnografia, arqueologia, folclore etc) de intelectuais que, já a partir de fins do século XVIII, começaram a especular sobre o (in)desejável desaparecimento dessa cultura 'menor', 'supersticiosa', 'ignorante' etc. Dessa cultura irremediavelmente fadada a ser 'superada' pela educação, pelo esclarecimento, pelo progresso...

Desse fascínio ambíguo e algo necrófilo da cultura aristocrática pela popular, em grande parte derivou o pouco que sabemos desta última (registros, escritos, monumentos...). É importante sublinhar tal aspecto, pois o que a elite resolveu conhecer e registrar sempre brotou de seu próprio ponto de vista. Daí ter banido dos livros didáticos e do ensino oficial, como pouco importantes ou desprezíveis, os ambientes humanos onde a vida efetivamente se dava, sacrificandoos em nome de conhecimentos, tantas vezes frívolos, relativos à cultura dos dominantes: a da corte, a do Estado, a da Igreja, a das instituições. Um certo esforço intelectual ser-nos-á sempre necessário, por conseguinte, para tentar moderar esse viés etnocêntrico e para, na medida do possível, corrigir em nós a preguiça viciada desse olhar que expressa nossa posição social.

Estes pontos são de conseqüências inestimáveis para um estudo sobre mentalidades e sensibilidades medievais. Também o são para a compreensão associada de nossos modos contemporâneos de pensar, de agir e de sentir. É bastante importante registrar que muito de nossa sensibilidade hodierna deriva exatamente 
desse afastamento em relação às práticas cotidianas das grandes massas da população. Nesses terrenos, começamos a ingressar no teatro de uma higiene parecida com a nossa. Subimos no palco de uma etiqueta que já é mais ou menos a que temos. Passeamos pela paisagem de uma indumentária que recorda a que portamos. Nesses territórios, passamos a integrar o cenário de uma concepção de cidade que já é similar à daquelas em que vivemos. Desabamos no abismo de um distanciamento do mundo que é semelhante àquele que cultivamos. Tudo isso deriva essencialmente dessa clivagem entre uma cultura 'de elite', respeitável, e uma cultura 'baixa', por ela cada vez mais desprezada e detestada. 


\section{2 \\ Fusão e Separação}

Ao tratar da Idade Média, emprestaremos nossas atenções primordialmente a esta cultura de todos - a cultura desprezada, colocada em evidência nas páginas antecedentes. O ponto de partida mais importante para esta empreitada consiste, sem dúvida, em observar e sublinhar fortemente, logo de início, que a cosmovisão medieval postulava uma integridade absoluta do universo. Isto significa que era uma espécie de amálgama o que se encontrava nuclearmente naqueles tempos, em que o macrocosmos e o microcosmos se fundiam, se indiferenciavam e não se contrapunham.

Quase tudo o que nós, cidadãos pertencentes às altas classes da sociedade capitalista industrial, costumamos representar como oposições, apresentava-se ao homem da cultura cotidiana da Idade Média como interpenetração ou equivalência. Aquilo que consideramos familiarmente como contraditório não tinha este sentido para o homem medieval. Na mente deste, "o Mundo enrolava-se sobre si mesmo: a terra repetindo o céu, os rostos mirando-se nas estrelas e a erva envolvendo nas suas hastes os segredos que eram úteis ao homem", para recordar as belas palavras Foucault (1968:64). Assim, o pequeno expressa o grande. A parte contém o todo. $\mathrm{O}$ indivíduo exprime a sociedade. A mão revela o destino. $\mathrm{O}$ rosto estampa o caráter. Esses princípios valem para tudo: o mínimo está no máximo; mas também pode ser continente do máximo.

Ao invés de ser considerada como massa inanimada, a Terra era vista como ser vivo (Thomas, 1991). O universo era povoado por uma hierarquia de espíritos, manifestando toda forma de simpatias e influências ocultas. O rei era um representante de Deus na Terra, "incumbido de manter a sociedade dos homens na mesma ordem que também rege as estrelas" (Duby, 1988:192). Também era responsável pela articulação do presente com o passado: por este modo de entender, os reis capetos podiam ser vistos como descendentes diretos dos carolíngios, que o eram, por seu turno, dos merovíngios (Bloch, 1988). O cosmos constituía, portanto, uma unidade orgânica, em que cada parte mantinha relação com as demais. Mesmo as cores, as letras e os números eram considerados como dotados de propriedades mágicas. Nenhum detalhe podia ser indiferente. 
Doutrinas elaboradíssimas, sustentando uma espécie de correspondência ou de inter-relação entre todas as partes do mundo, possibilitavam a fé tranqüila em sistemas divinatórios como a quiromancia, a fisiognomia, a astrologia... Ainda em 1631, em um manual citado por Keith Thomas (1991), afirmava-se peremptoriamente ser possível detectar se uma pessoa doente iria viver ou morrer apenas mergulhando-se uma folha de urtiga em sua urina por vinte e quatro horas: se a planta secasse, ela morreria; se continuasse verde e fresca, viveria. Em síntese, assim como se acreditava que o indivíduo espelhasse o mundo em miniatura, considerava-se que a mão ou o rosto indubitavelmente refletisse o indivíduo.

"O cosmos como grande homem; o homem como pequeno cosmos. Este é o ponto de partida de grande parte do alegorismo medieval" (Eco, 1989:52). Compreende-se, com base em princípios cosmológicos como tais, que a astrologia da Idade Média fosse menos uma disciplina especial e separada, como a conhecemos atualmente, que um aspecto corriqueiro de uma imagem de mundo bastante corrente e pacificamente aceita por quase todos. A consideração dos astros era necessária ao entendimento da fisiologia - e, portanto, parte da medicina da época, popular ou não. Dizia também das influências das estrelas sobre plantas e minerais, moldando a farmácia, a botânica e a metalurgia. $\mathrm{O}$ conhecimento do céu representava um aspecto essencial da estrutura intelectual em que os homens eram educados, não apenas nos segmentos instruídos, mas em todos os estratos sociais.

O mundo se desdobrava como um enorme sistema de símbolos. Como uma "catedral de idéias", para evocar a feliz expressão de Huizinga (1978:184). Era uma riquíssima concepção rítmica de encadeamentos, expressão polifônica de uma harmonia que se afirmava eterna. Na Idade Média, a compreensão simbolista valia muito mais do que quaisquer explicações causais ou genéticas, que viriam a ser tão intensamente importantes para a nova cultura dos séculos posteriores. Assim, os sistemas classificatórios supunham a existência de correspondências e analogias entre todas as partes da criação, fazendo o 'invisível visível', como acreditava Paracelso: é que as semelhanças (e diferenças) nunca eram consideradas gratuitas ou inúteis. Acreditava-se em uma espécie de doutrina de marcas (Foucault, 1968), segundo a qual, por exemplo, assim como os reis traziam no corpo o signo de sua realeza (Bloch, 1988), toda planta traria um sinal demonstrativo de suas finalidades: uma flor amarela, por exemplo, poderia indicar um provável remédio contra icterícia; uma raiz com formato aproximado ao de um pé tornava-se tratamento contra gota; um fruto que lembrasse um olho...

Um belo parágrafo de Lucien Febvre, ainda que se referindo a um tempo formalmente posterior ao medieval, ilustra e resume esta maneira de se verem as coisas:

Cai um raio: não é um fenômeno natural, mas ato voluntário e consciente da Divindade, intervindo bruscamente nos negócios humanos. Um cometa aparece no céu: não é um fenômeno natural, é um presságio, um anúncio, o anúncio de uma morte (...) em 1600 aparecerá um Traité 
de lápparition des Esprits, à sçavoir des âmes séparées, fantasmes, prodiges et accidens merveilleux qui précèdent quelquefois la mort de grands personnages ou signifient changement de la chose publique (...) Um eclipse, uma queda de aerólito, um livido pôr-do-sol: outros tantos signos, outras intervenções das potências celestes. Na trama de toda vida, natureza e sobrenatureza se entrelaçam perpetuamente, sem que alguém se surpreenda ou sinta incomodado. (Febvre, 1947:478-479) (grifos do autor)

Esta lógica de simbolismo e analogia pressupõe, do ponto de vista sociológico, uma espécie de concordância sobre e entre os traços essenciais do mundo. Por não configurar codificações rígidas, fixas e fechadas, ela supõe também que aconteçam contínuas negociações sobre as muitíssimas interpretações possíveis e sobre a delimitação de significados minimamente consensuais. Ao mesmo tempo em que exige incessante busca de consenso, esta lógica abre, por outro lado, a possibilidade de uma espécie de aventura semiótica: ousadias mediante as quais as pessoas têm a chance de poder se entregar à tarefa, para elas freqüentemente deleitosa, de descobrir ou inventar novas metáforas místicas ou poéticas.

Exatamente por viverem nesse contexto mental, os homens apresentavam extraordinária sensibilidade em relação ao universo que habitavam. Quase qualquer um era explicitamente consciente de fenômenos como posição dos astros e das constelações, fases da lua, localização do sol nas diversas estações do ano; também conhecia os riachos, as montanhas, os caminhos, os atalhos... Tais conhecimentos eram cosmológicos, mas também eminentemente pragmáticos, ligados à vida diária, servindo para tornar possíveis decisões, como o direcionamento noturno, a escolha de rumos, o planejamento de viagens, a previsão de plantio, de colheita e assim por diante.

Os medievais eram cônscios do mundo físico em que viviam. Muito mais do que nós, hodiernos, que - mesmo quando pouco expostos à iluminação artificial de nossas casas e cidades - estamos raramente atentos às fases da lua, sentimos com desinteresse a posição do sol, percebemos com pouca freqüência os eclipses... Somos seres que viajam por estradas já demarcadas. Em geral sentimonos dispensados de meditar sobre os itinerários...

Havia uma grande variedade de casas rurais nos tempos medievais. Comumente, todavia, eram casas de um único cômodo, no qual convivia um número variável de pessoas - e também de animais. Às vezes, além de forno, lareira, bacia, leitos, a casa continha celeiro, estábulo, depósito de feno... Habitações desse tipo foram muito comuns na história européia, continuando presentes inclusive no século XX, particularmente nas regiões ditas atrasadas. É óbvio que vivendas que obedeciam a esta inspiração eram acompanhadas de seus inevitáveis correlativos: ratos, moscas, pulgas, percevejos etc. É preciso ressaltar, entretanto, que esta coabitação sem segregação de animais e homens, nos tempos medievais, 
não se deveu de modo algum a condições econômicas especialmente miseráveis: foi um aspecto crucial e perfeitamente coerente de uma visão de mundo que deve ser considerada de modo positivo (Contamine, 1991).

A cosmovisão da Idade Média era inteiramente teocêntrica. "O medieval só conhecia um modo para modificar a ordem das coisas naturais: o milagre" (Eco, 1989:182). A idéia de impossível não tinha lugar. Em princípio, tudo era possível (Febvre, 1947). O universo estava completamente embebido de vontade divina. Nada deixava de ser viável, se estivesse de acordo com este fundamento que presidia o mundo e as vidas. $\mathrm{O}$ universo cotidiano estava inteiramente pontilhado por milagres, prodígios e maravilhas. Milagres não constituíam raridades e eram reconhecidos pelos próprios crentes ou por seus beneficiários. Não necessitavam ainda de instância hierarquicamente superior que os homologasse, como se procura fazer hoje em dia. Uma cadeia de correspondências analógicas estava sempre entrelaçando os desígnios divinos e os acontecimentos do dia-a-dia, atribuindo a tudo uma coloração de encantamento mágico. Deus não representava, em absoluto, uma espécie de proprietário privado do maravilhoso. Agia também por procuração, concedendo a todos e a tudo a possibilidade de fazer valer sua onipotente vontade.

Este Deus não era de modo algum um deus remoto. Estava ao alcance direto dos homens comuns, embora acessível mais freqüente e facilmente aos santos e por intermédio destes. Cultuar os santos era também agir sobre a vontade divina, provocar nela as curvaturas propícias. A divindade e, por conseqüência, o universo eram fisicamente sensíveis à conduta ritual e moral dos seres humanos. Quando ocorria uma tempestade, por exemplo, tocavam-se os sinos das igrejas, na tentativa de aplacar potências e deter a tormenta. Uma alternativa seria invocar Santa Bárbara, por meio de preces específicas, a fim de acalmar a violência dos trovões. Relâmpagos, eclipses, trovoadas, cometas não eram meros acontecimentos naturais: representavam mensagens com conteúdo moral, expressavam um estado de humor da divindade. Compreendem-se, assim, os exorcismos, cotidianos e ao alcance de todos, para tornar os campos férteis, para proteger os animais, para matar ervas daninhas, para afastar pragas, lagartas, ratos. Entendese, por este viés, que cada ofício medieval contasse com a proteção de um santo especial, honrado e venerado corporativamente. Explica-se que o mesmo acontecesse com relação a doenças e localidades.

Uma verdadeiro turbilhão de crenças enxameava em torno dos santos. Tudo contribuía para os tornar familiares, quase vivos, embora fossem sempre capazes de cometimentos extraordinários: São Marcelo, por exemplo, tomava pela mão um ferro em brasa e calculava seu peso com exatidão; fazia a água se transformar em vinho e multiplicava sua quantidade a ponto de uma multidão dele poder comungar; fazia caírem as correntes que prendiam um prisioneiro e operava o desaparecimento de um monstro com forma de serpente-dragão que apavorava a população (Le Goff, 1980). Ao mesmo tempo, esses personagens extraordinários 
eram geralmente representados na iconografia com trajes populares, acompanhando os modos usuais de vestimenta da época, como que a exprimir que sua excepcionalidade nada contivesse de excepcional.

Evidentemente, entre tais crenças se incluíam as que admitiam influências e simpatias ocultas - e isto é bastante coerente com o que acabei de dizer. Uma ilustração, mais ou menos extrema, é a que ficou conhecida como ungüento da arma (Thomas, 1991:166). A idéia-cerne, contida no ungüento da arma, era a de que se poderia curar um ferimento com uma pomada feita com o sangue que havia permanecido na espada que produzira a ferida. Espalhados sobre a arma, os espíritos vitais do sangue coagulado reunir-se-iam novamente ao corpo da vítima, podendo assim curar as conseqüências de sua ação com quilômetros de afastamento. Até boa parte do século XVII, médicos ilustres, fascinados pelas ações à distância, como as manifestadas pelos fenômenos magnéticos, discutiriam seriamente em torno do que designavam por unguentum armarium (Eco, 1989). Até o final do século XVIII, nas palavras de François Jacob, "não existe uma fronteira bem definida entre os seres e as coisas. $\mathrm{O}$ vivo se prolonga no inanimado sem descontinuidade" (1983:39).

Outro exemplo clássico, ao qual Marc Bloch dedicou uma obra magnífica (1988), era o toque real. Com esta expressão, Bloch colocou em evidência a capacidade que na França e na Inglaterra se reconhecia aos reis - e quase somente a eles - de curar doenças por milagre, especialmente escrófulas, apenas tateando as chagas dos acometidos. Os doentes, vindos de toda a Europa, compareciam anualmente aos milhares, em dias convencionados. Além de algumas orações, bastava aos reis pronunciar a frase seguinte, cujo teor é importante registrar por ser uma preciosa síntese da compreensão das coisas naquela época: "o rei te toca, Deus te cura" (grifo nosso). Este rito foi observado até 31 de maio de 1825, quando pela última vez, mas não sem os protestos dos tradicionalistas, um rei francês passou as mãos sobre feridas de escrofulosos.

Astrologia, feitiçaria, curas mágicas, adivinhações, profecias, fantasmas, duendes etc. eram possibilitados por essa lógica de um universo magicamente encantado. A manipulação de uma figura de cera representando uma pessoa, ou a de uma peça de vestuário que lhe pertencesse, poderia acarretar as conseqüências que se desejassem. Podiam-se causar danos ou benefícios a uma pessoa, manipulando-se-lhe os cabelos, aparas de unhas, suor, excrementos: tudo isso continha espíritos vitais. Amuletos, talismãs e poções faziam parte do cotidiano: maços de ervas presos aos braços, às pernas ou à cabeça para dar sorte, por exemplo. Um enfermo poderia ser curado por bebida feita com cinzas da cabeça de um morto. Os carrascos eram incessantemente procurados como fornecedores de poções miraculosas, derivadas da gordura de executados. Mães colocavam suas crianças doentes em túneis escavados na terra, cobertos por espinhos, ou dentro de troncos de árvores, até que elas - índice de cura - cessassem de chorar. Uma fita 
atada à roupa de um homem poderia torná-lo impotente; mas o pão elaborado com o trigo que teve contato com as partes genitais de uma mulher poderia ter o efeito oposto. Do mesmo modo, peixes introduzidos na vagina - e aí mantidos até que morressem -, posteriormente temperados e cozidos, eram oferecidos ao amante, junto com toda a força afrodisíaca e geradora que amealharam (Rouche, 1992). Em meio à diversidade de práticas e crenças, o princípio é invariável, entretanto: capturar as forças vitais, embeber tudo de sagrado, fazer o cosmos inteiro penetrar no pontual. A caça às bruxas, positivamente, é um fenômeno moderno.

Sistemas de crença desse tipo costumam perdurar. Os reis não curam sempre, nem os santos, nem os curandeiros. Não obstante, ninguém duvida de seus poderes apenas por causa disso. A autoconfirmação é característica de modos de pensamento dessa espécie. Uma vez acolhidas as premissas básicas, nenhuma descoberta subseqüente, na prática, conseguirá abalar a fé do crente. Todo novo evento tenderá a ser explicado nos termos do próprio sistema. Suas certezas também não serão abaladas pelo fracasso eventual de um rito que deixe de produzir o efeito desejado. Tal acontecimento poderá ser explicado e digerido, atribuindo-se o fato a erros circunstanciais na aplicação de fórmulas em si mesmas infalíveis.

Semelhantes sistemas de crenças têm ainda uma imensa capacidade de recuperação, o que os torna virtualmente imunes a argumentos externos. Assim, se os doentes não curam, os curadores os acusam de não terem vindo a tempo, de não terem aplicado as fórmulas corretamente, de não terem tido fé o bastante; alegam que o problema eventualmente irresoluto é tão grave, que constitui obra de ou para um feiticeiro ainda mais poderoso; argumentam que o feitiço era mais forte do que se havia calculado... O resultado de crenças desse teor é que as pessoas poderão ser céticas em relação a um ou outro feiticeiro em particular, raramente quanto à feitiçaria em geral.

Todos estes exemplos eram perfeitamente compatíveis com o cristianismo popular. No entanto, ao longo do tempo, tais crenças e práticas passaram a ser consideradas parasitas dos ensinamentos cristãos oficiais, de teor crescentemente racionalista. Daí resultava, com freqüência, que a Igreja se posicionasse, do ponto de vista ortodoxo e pelo prisma do alto clero, em franca rivalidade e indisposição com relação a estes modos de crer, de agir e de sentir. A noção posterior - de que o universo está sujeito a leis naturais - veio liquidar a importância do milagre e diminuir a crença na eficiência da oração. Com o triunfo progressivo do catolicismo oficial e, sobretudo, com os reformadores protestantes, aquela imagem mágica do universo foi-se gradativamente confinando e arrefecendo. Primeiro, preservando-se em setores sempre mais específicos da população. Depois, contendo-se no âmbito de disciplinas ou saberes especiais.

Foi nesta direção, por exemplo, que a astrologia perdeu gradualmente o seu papel proeminente como uma espécie de simbolismo universal e se cristalizou em sistema de crenças separado, ao qual a elite e seus imitadores prestavam cada vez 
menos adesão. No início do século XVI, esta mudança ainda estava por acontecer. No século XVII, ainda que se continuasse a prescrever o uso de morcegos, anéis, cobras, raízes, folhas etc. para as mais variadas finalidades, as justificativas oferecidas não mais se baseavam em princípios de analogias e implicações simbólicas ou alegóricas.

Doravante, seria com base em propriedades naturais efetivas e supostamente imanentes (Thomas, 1991) que semelhantes práticas e crenças buscariam tornar-se intelectualmente aceitáveis. As causalidades mágicas e miraculosas cederiam lugar às causações físicas. E o mundo passaria a ser cada vez mais concebido como um mecanismo. Sutil, mas significativo indicador dessa mudança de mentalidade, a imprecação real para curar escrófulas sofreu uma modificação no modo verbal: o indicativo entregou seu posto ao subjuntivo, e a fórmula ritual passou a ser: "o rei te toca; Deus te cure." (Bloch, 1988:363). Nesses novos tempos, não se tinha mais certeza.

Não obstante estas modificações de mentalidade, por muitos séculos o catolicismo foi e seria ainda obrigado a conviver com o cristianismo meio pagão de uma população para a qual Deus era capaz de rir, de ficar irado, de se acalmar. Esse Deus castigava, de acordo com o que os homens tivessem feito ou consoante suas omissões. Mas esse Deus também era adulável, não era imune à sedução. Nada acontecia por acaso. Os homens eram responsáveis. Um jogo de persuasão com a divindade poderia favorecer tudo; ou, se mal feito, pôr tudo a perder. Esse Deus poderia ser temível e com constância era temido. No entanto, também poderia ser cúmplice. Havia uma espécie de intimidade entre o terreno e o celestial.

'Intimidade' não chega a ser propriamente uma expressão adequada aos tempos de que estamos falando. Como veremos adiante, ela é uma daquelas noções que apenas muito posteriormente encontrariam alguma densidade sociológica na história do Ocidente. A idéia de intimidade, como algo que deva estar separado, como coisa que deva ser posta à parte, surgiria em nossa história lentamente e muito depois. O conceito de íntimo, nesse contexto, não tem o sentido de preservado, mas o de misturado. Não o sentido de 'aquilo que se deva esconder', mas o de 'nada há a esconder'. De qualquer forma, na Idade Média, o celestial e o terreno eram inteiramente próximos. Havia uma extraordinária e intensa familiaridade entre as coisas sagradas e os homens. Homens e divindades conviviam, como tudo e como todos, comunitariamente. Trocavam ofensas, promessas, favores, xingamentos, cobranças, torturas...

Em geral, as atitudes das pessoas diante de Deus tendiam a ecoar as convenções sociais. Na igreja, tiravam o chapéu e se ajoelhavam, como diante de seus superiores na sociedade. Também ouviam as confissões de seus iguais, que eram mais ou menos públicas, pois ainda não havia sido inventado o moderno confessionário fechado. Aliás, quando o foi, como uma inovação do século XVI (Thomas, 
1991), esta peça de mobiliário servia, na prática, mais para separar o penitente do padre que para apartar os fiéis entre si, visto que o hábito de falar baixo ainda não se tinha generalizado socialmente, mesmo dentro dos templos.

Reafirmando a familiaridade no relacionamento com o divino, os rituais de Deus eram os da sociedade. No entanto, essa familiaridade entre o terreno e o celestial às vezes era tamanha, que a conduta de muitos freqüentadores deixava a desejar. Chegava-se ao extremo de converter o ofício religioso em arremedo do que se pretendia oficialmente: pessoas se empurravam disputando lugares a cotoveladas, pigarreavam e se davam tapas, tricotavam, faziam comentários grosseiros, contavam piadas, dormiam e até descarregavam armas dentro das igrejas.

Em sua obra $O$ Ano Mil, Georges Duby narra a seguinte cena, que vale a pena reproduzir, pelo que condensa de interessante e de revelador no que concerne ao quadro que estou tentando pintar. Ao mesmo tempo, também revela algumas das tendências de transformação dessa paisagem:

Um irmão deste convento tinha o hábito, o que é excelente, de ir ao altar da bem-aventurada Maria para ai rezar e desatar em gemidos e lágrimas de compunção. Mas tinha o defeito, comum a quase toda a gente, de cuspir freqüentemente durante as suas orações e de deixar escapar a saliva. Aconteceu que uma vez, abatido pelo sono, adormeceu. Apareceu-lhe então, ao pé do altar, um personagem envolvido em roupas brancas, tendo nas mãos um tecido muito branco, que lhe dirigiu estas palavras:

"Por que me cobres com esses escarros que lanças? No entanto como vês, sou eu que me encarrego das tuas orações e as levo à vista do Juiz muito misericordioso".

Perturbado com esta visão, o irmão não somente se vigiou, como ainda teve o cuidado de recomendar aos outros que melhor se vigiassem nos lugares sagrados. Se bem que seja uma necessidade natural de qualquer maneira as pessoas abstêm-se, na maior parte das regiões, de lançar escarros numa igreja; a menos que ai haja para os receber recipientes que em seguida se esvaziam no exterior; os mais atentos neste aspecto são os gregos, nos quais as regras eclesiásticas foram sempre escrupulosamente observadas. (Duby, 1986:138-139)

Keith Thomas (19991), por seu turno, refere-se a um documento, agora de 1598 , por meio do qual um homem, em um condado inglês, foi denunciado por comportamento indecente dentro da igreja: "peidos extremamente repugnantes, palmadas e comentários de mofa, provocavam o grande escândalo dos bons e o regozijo dos maus". Exageros à parte, sabemos todos que não é necessário mergulhar muito profundamente no tempo para compreender esses traços, pois tais características estão até hoje vivíssimas no catolicismo popular - fato de que o Brasil é uma ilustração nada excepcional. 
O imaginário tinha, na vida cotidiana, um lugar que dificilmente alguém com a nossa visão de mundo poderá avaliar. Na existência do medieval, o imaginário tinha uma presença tão intensa e se manifestava de modo tão extremo que, se atuante em uma pessoa dos nossos tempos, certamente a colocaria em um hospício. Visões prodigiosas: cavalos alados, exércitos aéreos, anjos, dragões, monstros, pássaros voando sobre o leito de moribundos, fantasmas que afundavam navios etc. A literatura relatava coisas espantosas como se fossem perfeitamente verdadeiras: testemunhos de seres monstruosos que alguém tinha visto, surgidos de oceanos ou de terras desconhecidas; narrativas de experiências fabulosas; augúrios extraordinários; presságios fantasiosos...

Nas entrelinhas dos relatos de viagens pode-se perceber que, com bastante freqüência, as pessoas não pareciam fazer distinção entre o que supunham acreditável em virtude de ter sido visto, ou em razão de ter sido ouvido. A Idade Média privilegiava a oralidade e atribuía ao dito uma credibilidade que nós, seres do escrito, tenderíamos a considerar mera e ingênua credulidade. Mas a audição como em geral acontece nas culturas em que o importante se transmite pela fala tinha valor cognitivo positivo, que não implicava dúvidas ou exigia comprovações. Como observou Jacques Le Goff (1985), os homens medievais, se os compararmos aos renascentistas, não sabiam olhar. Todavia, estavam sempre dispostos a acreditar em tudo aquilo que se lhes dissesse. Viviam imbuídos de lendas tidas como realidade e levavam consigo essas miragens onde quer que fossem.

Decorrência perfeitamente compreensível da inseparabilidade entre real e imaginário, os acontecimentos do sonho e da vigília não constituíam universos distintos. A concentração cotidiana sobre as mensagens divinas fazia que percepções banais da existência consciente fossem sempre matizadas pelas alucinações apaixonadas do sonho: "as figuras recolhidas pelo olho interno eram tão reais quanto as percebidas perifericamente pela retina" (Mumford, 1977:343). Sonhar era sempre profético; era sempre intuir; era sempre adivinhar. O sonho sempre revelava alguma coisa. Mas não do modo como hoje, influenciados pela psicanálise, costumamos entender.

Não era absolutamente necessário dormir para sonhar. O sonho estava presente e ativo aqui e agora. Não era coisa para ser analisada como objeto cuja positividade estivesse em outro tempo ou lugar. Não era fenômeno para ser posto sobre a mesa (ou divã, tanto faz) e dissecado. Não era suposto que expressasse alguma coisa 'outra', uma verdade inconsciente que estivesse por detrás. $\mathrm{O}$ sonho, nos tempos medievais, ainda não representava algo que remetesse para dentro do sonhador, para um âmago íntimo e insondável de si mesmo.

$\mathrm{O}$ onírico medieval era antes de tudo um vínculo que atava o sonhador a um passado exterior a si e a um futuro predizível. Sonhar era fazer pontes: entre o pontual, particular, e o cósmico, universal. A interpretação dos sonhos existia e era um serviço prestado com freqüência por magos e astrólogos a seus clientes. 
No entanto, tratava-se mais propriamente de injetar do que de retirar sentido ao sonhado. Além disso, não se era apenas paciente dos sonhos: havia fórmulas especiais para produzir ativamente determinados sonhos, para submeter o sonho à vontade. Por exemplo, colocar um objeto sob o travesseiro de uma moça, para que ela pudesse ver seu futuro marido (Thomas, 1991).

A aparência continha tudo. Mesmo que remetesse a infindáveis imagens e que, por meio destas, frutificasse incessantemente em derivações analógicas e alegóricas, a aparência não constituía mero resíduo. Não era necessário negar o que parece ou aparece para descobrir - em uma camada oculta - o que efetivamente 'é'. A aparência não existia para ser negada em proveito de uma essência escondida em algum bastidor, lugar em que viveriam os eventos e personagens efetivamente decisivos. A aparência era considerada positiva: já revelava por si mesma. Mais ainda, sua riqueza não se esgotava aí. Entre aparência e essência, existiam as infinitas mediações da imaginação.

Está implicado, neste ponto, que para a mentalidade medieval 'falso' e 'verdadeiro' não se opunham. Ao menos, não se contrapunham de forma mutuamente exclusiva, como costumamos conceber. Verdade é algo em que se crê, se previamente se aceitam os critérios que definem algo como verdadeiro. Neste sentido, pode-se dizer que verdadeiro e falso não se contraditavam na Idade Média, pois eram outros os critérios de verdade.

A Idade Média sempre dedicou imensa desconfiança à solidão. Esta é a razão pela qual os eremitas constituíam personagens estatisticamente excepcionais, embora tenham sido, como sabemos hoje, importantes prefiguradores de um novo modo de ser. Coerentemente, salvo talvez no meio daqueles raros personagens, é compreensível que entre dois critérios polares de definição de verdade só se pode dizer a verdade do mundo separando-se dele ou só se pode afirmar a verdade do mundo misturando-se com ele -, a mentalidade medieval, em geral, tomasse francamente o partido do segundo.

No contexto medieval, a verdade se define por experiências próprias de cada um. Desenha-se também por experiências de outras pessoas que sejam dignas de fé. Constrói-se ainda por indicações cósmicas ou místicas, como no ordálio ou no sorteio. Verdadeiro, em princípio, era aquilo que afirmo ter experimentado, que garanto ter acontecido. Verdadeiro é também aquilo que foi dito ou afirmado por pessoas que têm credibilidade na comunidade. Verdadeiro é ainda aquilo que recebeu o sopro do aleatório. $\mathrm{O}$ que chamamos de 'acaso' tinha nesse pensamento uma força de verdade, porque traz em si algo da vontade divina. E o que designamos 'experiências subjetivas' (de que, sobretudo depois do desenvolvimento do pensamento científico, passamos a desconfiar, bradando os nomes da objetividade e da neutralidade) tem, no contexto de que estamos tratando, uma positividade que vale por si.

Os sábios medievais ainda não consideravam que lhes pertencesse a tarefa de descobrir 'leis', ou de, mergulhados em uma enorme massa de dados aparen- 
temente desconexos, descobrir-lhes com exatidão uma ordem subjacente, uma classificação ou hierarquia (Febvre, 1947). Não se distinguia entre a necessidade dos fenômenos e a contingência dos acontecimentos (Jacob, 1983). A objetividade científica, de certo modo, era incogitável nessa cultura, tendo em vista que nem se admitia que o objeto fitado tivesse qualidades passivas (o que seria totalmente contraditório com tudo o que venho afirmando sobre a mentalidade medieval), nem, muito menos, se supunha o valor absoluto de um olhar que se pretendesse despojado de tendências subjetivas.

Fazendo um interessantíssimo levantamento de palavras ainda não nascidas no século XVI, Lucien Febvre registra o problema que estamos examinando:

nem absoluto, nem relativo, nem abstrato, nem concreto, nem confuso, nem complexo (...) nem virtual (...) nem insolúvel, intencional, intrínseco, inerente, oculto, primitivo, sensitivo, todos vocábulos do século XVIII; nem transcendental, que ornamentará por volta de 1698 os períodos de Bossuet (...) Mas, e os substantivos? (...) Nem causalidade, nem regularidade, nem conceito, nem critério, nem condição (...) nem análise, nem síntese (...) nem dedução (...) nem indução, que só nascerá no século XIX; nem muito menos intuição (...) nem coordenação ou classificação (...) sistema (...). (Febvre, 1947:385)

E não estava presente a própria palavra que serviria para designar 'Racionalismo', cujo batismo não se faria senão no século XIX.

Insistamos um pouco sobre este assunto. No Direito Germânico, ser acusado de haver praticado um crime era, em princípio e por si mesmo, uma coisa gravíssima. Compreende-se isto facilmente, pois, em um ambiente comunitário, tornar-se suspeito já configura, de modo intrínseco, algo reprovável, uma vez que a suspeita estremece radicalmente a confiança recíproca em que a solidariedade se apóia. Da mesma maneira, cada assassinato era codificado segundo a condição social do morto. Tudo o que contava era sua posição na hierarquia. Uma das formas de se decidir se um acusado devia ser condenado ou absolvido consistia em lhe propiciar a oportunidade de reunir um certo número de pessoas 'de bem', estimadas como dignas (doze, em geral - e não por acaso), que afirmassem não acreditar que o imputado tivesse praticado o cometimento que lhe atribuíam.

Aceitava-se perfeitamente, nesses casos, que o júri não fosse formado por avaliadores imparciais - que, segundo os critérios de nossa cultura hodierna, estariam obviamente mais aptos a tomar decisões neutras e verdadeiras. Na Idade Média, muitas vezes os julgadores eram membros da comunidade da qual provinha o acusado. O princípio de sustentação desse proceder era a suposição de que aqueles eram mais bem informados sobre a posição geral do réu na comunidade (Thomas, 1991). As questões se resolviam, portanto, não em virtude de uma pleiteada verdade objetiva ter sido alcançada - o inquérito, a que Foucault (1974) dedi- 
cou páginas tão importantes, ainda não havia nascido -, mas solucionavam-se em razão de o acusado ter, ou não, conseguido demonstrar que representava uma pessoa importante para a coletividade.

Poder-se-ia ainda, por ilustração, obrigar o acusado a remar em direção ao alto-mar em dia de tempestade. Se retornasse vivo, as potências cósmicas estariam com ele: ei-lo absolvido. No século XII, era comum exigir-se que juramentos fossem feitos sobre uma tumba: caso o acusado assumisse tamanho risco, considerava-se estar ele com a 'verdade', posto que o fantasma do morto cruel e inapelavelmente vingaria um eventual perjúrio (Thomas, 1991). A força de qualquer juramento aumentava se este fosse associado a um objeto sagrado, bíblia ou relíquia, por exemplo. Às vezes, fazia-se a pessoa suspeita de homicídio tocar o cadáver da vítima, prática inspirada na crença de que, se culpada, o corpo soltaria nova golfada de sangue. Tais procedimentos, alguns dos quais ainda verificáveis em nossos tempos, foram com freqüência utilizados formalmente por juizes e magistrados encarregados de decidir ocorrências suspeitas.

Lógica semelhante operava nos sorteios, sobretudo para resolver questões potencialmente conflitantes, tais como a escolha do santuário a visitar, o destino de bens pleiteados por mais de uma pessoa, a designação de um funcionário municipal, o lugar das pessoas nos bancos da igreja, a época adequada para semear, o condenado escolhido para morrer... O resultado era tido como materialização do mais fundamental dos critérios de 'verdade': a vontade divina.

'Verdade', assim, nesse contexto, é aquilo que a comunidade e os poderes nela imperantes querem que seja verdade. Mais ainda, em uma cultura que acolhia esses princípios, tal lógica era também uma forma de controle social, agindo, de modo estatístico, sobre o conjunto e a generalidade da população, mais do que sobre cada ser humano singular. O principal efeito sociológico de tais práticas e crenças era fundamentalmente preventivo, tratando prioritariamente de dissuadir criminosos potenciais de perpetrar cometimentos condenáveis. Diante de lógica com semelhantes características, não poderia haver 'crime perfeito' (Thomas, 1991).

Nos debates universitários, especialmente no célebre disputatio (Foucault, 1974), uma tese era tida por 'verdadeira' de acordo com a quantidade de autores reputados que alguém fosse capaz de citar em seu favor. Neste procedimento, quem fazia a verdade era a autoridade da comunidade. Era a força da tradição, não a da descoberta. A da imitação, não a da originalidade. A atribuição de uma proposição a um autor constituía procedimento indispensável na intelligenzia medieval, visto que representava um índice fundamental de veracidade.

Autores eram autoridades: a proposição extraía do(s) autor(es) mesmo(s) sua condição de verdadeira - não exatamente por causa do autor em si, como indivíduo particular, mas pelo que este condensava em termos de reconhecimento social. Em determinadas esferas de conhecimento, como o Direito, este traço como sabemos - continua vivíssimo. Entretanto, desde o século XVII, esta ca- 
racterística (apesar das numerosíssimas exceções) não cessou de se apagar no discurso científico: funciona apenas para dar nome a uma teoria, a uma experiência etc. $\mathrm{O}$ oposto aconteceu no romance, em que textos que circulavam anonimamente na Idade Média passaram, cada vez mais, a ser atribuídos a um autor (Foucault, 1971).

Se o 'verdadeiro', em última instância, reduzia-se ao divino, de certo modo confundia-se também com o 'bom' e com o 'belo'. Não se concebia que uma religião da vida se separasse de uma religião da beleza ou de uma religião da ética (Huizinga, 1978). Não se imaginava o especificamente artístico, ou seja, a produção de obras que tivessem como objetivo exclusivo ou primeiro a fruição estética. Nas palavras de Umberto Eco (1989:28),

a passagem da alegria estética para a alegria do tipo místico é quase imediata. A degustação estética do homem medieval não consiste em se fixar na autonomia do produto artístico ou na realidade da natureza, mas em colher todas as relações sobrenaturais entre o objeto e o cosmos, em perceber na coisa concreta um reflexo ontológico da virtude participante de Deus.

Também não se concebia o especificamente ético. Na cultura laica e popular, não havia lugar para impor nítidas distinções maniqueístas. $O$ espírito do 'mal' ainda não havia passado a integrar o dogma central do cristianismo, tanto que pinturas representando o diabo não foram comuns até o século XII. Não existia, na mentalidade dos cristãos dos primeiros tempos, aquele fascínio algo mórbido que viria a criar fantasmas demoníacos em profusão, de que talvez a Divina Comédia e a obra de Jeronimus Bosch são importantes referenciais históricos.

"A Igreja primitiva ainda é uma Igreja transbordante de otimismo, plenamente confiante em sua fé e no triunfo da mesma" (Nogueira, 1986:24-25). O bem preponderaria sobre o mal, no final das contas, simplesmente porque este último não fazia parte do plano da criação $(E c o, 1989)$. Aquilo que foi em princípio tinha todo o direito de continuar sendo: o prestígio do passado só poderia ser argüído por um passado ainda mais venerável, pois nada vale tanto quanto o que já foi (Ariès, 1989). Contudo, ainda que em teoria não predominasse uma lógica de exclusão, na prática havia sempre ambigüidades surpreendentes, em relação às quais sempre convém ser prudente (Le Goff, 1989:24).

A excomunhão, análoga ao banimento, a maior de todas as penalidades, por expulsar alguém não apenas dos sacramentos, mas também da comunidade -, implicava uma liturgia terrificante. Em teoria, o excomungado não tinha mais permissão para comer ou trabalhar com outras pessoas; seu testemunho não era mais aceito nos tribunais e seu cadáver deveria ser lançado em terreno não-consagrado (Thomas, 1971; Geremek, 1989). 
Ocorre que, exatamente por esta razão - o fato de ser a penalidade mais grave -, a excomunhão era relativamente rara, bem ao contrário daquilo que se costuma fabular sobre a Idade Média. Como se sabe, a lógica de exclusão e separação só gradativamente se foi estabelecendo. E isto à medida que as diferenças e oposições entre as mentalidades folclórica e oficial se foram aguçando: quando se tornou menor a ênfase em valores como generosidade e espontaneidade, quando diminuiu a tolerância em relação à desordem. Quando bem e mal, bons e maus, belo e feio começaram a se incompatibilizar e a exigir mútuas exclusões.

Nos mosteiros, os que cometiam algum erro poderiam até mesmo ser flagelados. Poderiam também, por um tempo que se considerasse necessário à sua purificação, ser separados da comunidade, passando, por exemplo, a se alimentar à parte, sendo obrigados a permanecer à porta da igreja, como um castigo, tendo a cabeça coberta, para dar ainda mais peso a seu isolamento. Isto acontecia porque a solidão era concebida como um exílio, como uma prova, um castigo, punição. Quase sempre esta pena seria provisória: uma vez purgada a falta, a separação deveria cessar, as portas deveriam reabrir-se e o faltoso deveria refundir-se na comunidade (Duby, 1991c). 


\section{3 \\ Espírito e Matéria}

Um dos aspectos mais característicos e de mais difícil entendimento para a mentalidade contemporânea é que espírito e matéria não se opunham. Não se imaginava, nos tempos medievais, que os seres humanos possuíssem, por um lado, um espírito - indestrutível, transcendente e sublime - que se contrapusesse, por outro, a uma matéria fadada à degradação e à decomposição, por ser portadora de dignidade menor. A corporalidade medieval era valorizada em si, até porque continha o que hoje chamamos de 'espiritual'. Conhecer os mistérios da vida era antes de tudo perscrutar os desígnios de Deus, supondo-se que animassem simultaneamente corpo e alma, espírito e matéria, natureza e sociedade...

Com freqüência, as práticas medievais evidenciavam bastante nitidamente a dificuldade de separação dessas categorias que, hoje, para nós, são tão distintas. A crença em milagres, por exemplo, não apenas expressava suposições sobre os poderes da divindade, como também configurava um modo muitíssimo especial de entendimento do que fosse 'matéria' e das leis que a regiam. No que se refere ao culto às relíquias - ao mesmo tempo um amor espiritual aos santos e apego piedoso às coisas materiais -, pode-se afirmar algo semelhante: jamais entenderíamos as razões de as pessoas viajarem transcontinentalmente para honrá-las e pedir proteção, ou de competirem implacavelmente para serem enterradas o mais perto possível delas (no que os poderosos se saíam sempre melhor, aliás), se não levássemos em consideração a lógica de indistinção metonímica entre as virtudes do corpo (no caso, um fragmento de cabelo, sangue, osso) e as virtudes contidas na alma dos santos.

Obedecendo a essa mesma lógica de amálgama entre corpo e alma, é possível compreender perfeitamente que os reis da França, com freqüência, tivessem seus corpos esquartejados e que os fragmentos resultantes fossem espalhados coração aqui, cérebro ali - pelas igrejas importantes do território. Além da crença de que este procedimento fosse intrinsecamente propiciador de boas colheitas, tratavase de uma prática interessante, a das relíquias reais, pelo que exprimia simbolicamente: uma situação política de unidade de múltiplos, em que a unidade do reino se expressava pela fragmentação do rei. O costume de esquartejar o soberano era 
muitíssimo diferente daquilo que ocorreria séculos depois, quando se preferiria erigir gigantescos monumentos, em geral na capital do império, para que os monarcas fossem enterrados 'inteiros', simbolicamente representando a unidade do Estado e a conseqüente repressão dos múltiplos.

Este era também, provavelmente, o sentido do que poderíamos chamar de 'anti-relíquias'. Com esta expressão, pretendo fazer referência à prática, relativamente comum em quase toda a Europa, de esquartejamento de cadáveres de condenados ou dissidentes, isto é, de fragmentação de pessoas cujos cometimentos houvessem portado ameaça de desmembramento do corpo social: pendurados, expostos à visão de todos, simbolicamente dilacerados em partículas que os poderosos dissipavam pelo território de seus impérios, esses cadáveres estavam lá para lembrar metaforicamente o amaldiçoamento do espírito pelos destinos da matéria. Na margem oposta de um oceano, e com alguns séculos de distância, talvez não fosse abusivo considerar o destino do corpo de Tiradentes como mais uma ilustração desse tipo de pensamento e de sensibilidade.

O simbolismo corporal tinha lugar crucial nos padrões medievais de pensamento e sentimento. A mudança de sua significação, como veremos, não será absolutamente neutra: reverberará profundíssimas transformações históricas. O corpo medieval não era um mero revelador da alma: era o lugar simbólico em que se constituía a própria condição humana. Ainda após a morte, ou a caminho do além, era em forma de corpo (corpo que se desprendia de um corpo, corpo de criança...) que a alma se apresentava para cumprir seu destino: nada, portanto, de uma entidade puramente etérea, volátil, imaterial. O além, desde os primeiros cristãos (Brown, 1992), sempre foi sensual e cheio de delícias: lá, os homens deveriam contemplar os rostos eternamente belos e tranqüilos dos santos, lá poderiam encontrar um lugar fertilizado por águas refrescantes, lá encontrariam paragens de onde teriam desaparecido a dor, o sofrimento, as lágrimas...

Vivemos hoje em um tempo - o dos analgésicos e anestésicos - em que sofrer não tem mais sentido. Em parte por isso, somos um pouco incapazes de avaliar o sentido da dor. Nestas condições, se quisermos entender a sensibilidade de outros tempos e de povos diferentes, será preciso levar em consideração que, praticamente durante toda a sua existência, a humanidade foi obrigada a lidar com o sofrimento por outros meios que não os técnicos. Sobre esta questão, a propósito, Ivan Illich nos legou páginas memoráveis (1975).

Sempre foi por meios culturais, integrando-a ou não a um sistema de significação, que os homens atribuíram sentido à dor, desenvolvendo diferentes espécies de 'arte de sofrer', que hoje nos soariam verdadeiramente absurdas. Em âmbito específico, as soluções sempre foram as mais diversificadas, embora em geral sempre se tivesse procurado, por intermédio de mitos que a explicassem e justificassem, associar a dor a um conjunto de virtudes. No âmago destas, o sofrer vinha a adquirir conotação positiva: provas por que se deveria passar a fim de obter recompensas, 
desligamento das coisas vãs, solidez da fé, sabedoria inabalável, estoicismo superior, purificação mística, compensação de felicidade, antecipação de prazer... O sofrimento não desaparece absolutamente, na maioria dos casos. Nem é o que se pretende nos sistemas de representação da dor. Não obstante, neles o sofrer torna-se digerível pela vida. Apresenta-se como experiência humanamente suportável.

A inseparabilidade entre o corpo e a alma se traduzia de modo vivo na sensibilidade medieval relativa à dor. Ainda hoje, a dor corporal é denominada em muitas línguas européias por termos que designam também amargura, tristeza, punição, aflição, agonia, desânimo, luto, solidão, dificuldade, opressão, ou seja, é associada a sentimentos ou estados não necessariamente ligados à pura corporalidade. Tais associações guardam a memória de um tempo em que o sentido da dor ainda era cósmico e mítico, não individual e técnico. Pensemos, como ilustração, nas palavras do rei Luís XIV, em 1715, em seu leito de morte, conforme o relato do Duque de Saint-Simon em suas Mémoires. Perguntado pelo confessor se sofria, respondeu: "Não, e é o que me aborrece; eu queria sofrer mais, para a expiação de meus pecados".

A tortura é um dos traços atribuídos aos tempos medievais que mais chocam nossa sensibilidade hodierna. Isto se dá exatamente por operar sobre este ponto tão crucial, que é para nós a separação entre corpo e alma. Figuramos um quadro da Idade Média, nem sempre perfeitamente justo, como já adverti, em que torturas e execuções eram publicamente contempladas, mais ou menos como se constituíssem diversões de feira ou circo. Pelas razões que lembrei páginas atrás, comprazemo-nos em imaginar os medievais como seres sádicos, que apreciavam recusar aos desgraçados que torturavam o golpe de misericórdia que estes desesperadamente imploravam. Tudo isso, pensamos, tão-somente com o fito de que um público sedento de sangue e urros pudesse deleitar-se, regozijando-se com os tormentos de um ou de vários infelizes. Contudo, a grande verdade é que os tempos medievais não insistiram tanto quanto épocas posteriores nos sofrimentos dos supliciados. Muito pelo contrário, até: na Idade Média, o próprio Cristo e os mártires da fé cristã, em vez de corporalmente despedaçados, apresentavam-se normalmente com aspecto glorioso e triunfal.

As coisas não se dão de modo tão simples, portanto. Ocorre que a tortura está longe de ser excepcional nas sociedades humanas. Por maior repugnância que nos inspire, é preciso admitir que, em uma sociedade em que sofrer tem sentido, a tortura se incorpora nos sistemas simbólicos. Antes de tropeçar em preconceitos etnocêntricos rasteiros, admitamos que é preciso ir às várias culturas para desvendar a mensagem específica trazida pela tortura. No caso da mentalidade medieval, era possível justificá-la como uma ação sobre o espírito, por meio daquilo que chamaríamos de corpo: todos os sofrimentos impingidos ao corpo eram sofrimentos estabelecidos sobre a alma e vice-versa. A tortura, por esta razão, até mesmo poderia ser uma garantia de salvação, naquele contexto simbólico. Ela anteciparia, nesta vida, o pagamento de uma dívida, potencialmente reservado para a outra. 
Assim, ao mesmo tempo em que representava punição, a tortura poderia também constituir absolvição. Não se tratava em absoluto, no caso da tortura medieval, por mais asquerosa que nos pareça, de manifestação de um impulso cego de agressividade. Muito menos se tratava de um característico singularizador de um tempo específico, que estaria hoje 'felizmente superado pelo progresso'. Quanto a esta alegada superação, Auschwitz e Hiroshima, assim como tantos eventos semelhantes, pontuais ou continuados, não estão, aliás, suficientemente próximos de nós para impedir-nos de esquecer? Por si só, tais acontecimentos não seriam capazes de nos fazer mudar de opinião?

A tortura medieval expressava os princípios de uma visão de mundo estruturada. Era isto, por exemplo, que atribuía sentido a certas práticas, como o suplício ou a condenação à morte dos cadáveres daqueles a respeito de quem se descobriu ulteriormente terem praticado crimes passíveis de semelhante punição. Não se tratava, evidentemente, nesses casos, de buscar berros e gemidos, por impulsão da maldade. Tais costumes nos ensinam que estamos diante da operação simbólica de uma lógica para a qual o corpo não perdia aquilo que o animava, mesmo quando estivesse morto. Compreenda-se: para uma mentalidade que não separava espírito de matéria e que também não distinguia corpo de alma, cadáveres jamais poderiam ser meramente cadáveres.

$\mathrm{Na}$ contracorrente de nossos preconceitos, seria bastante interessante registrar que esta alegada 'cultura da tortura', esta 'cultura sanguinária', tinha por ofícios indignos (Le Goff, 1980) justamente aqueles ligados ao rompimento do tabu do sangue, tais como barbeiros, cirurgiões, açougueiros, carrascos... Inspirado nesses princípios, compreende-se que o Concílio de Tours, em 1163, tenha formalmente proibido os médicos monásticos de produzirem sangramentos como parte do tratamento de seus clientes - fato cuja explicação reside em que esta tarefa era considerada de menor dignidade, razão pela qual deveria estar severamente reservada a outros especialistas.

Os tempos medievais tinham a abertura do corpo humano por uma ação de todo inconcebível e até mesmo por um gesto do mais supremo sacrilégio. Ainda que fosse praticada com finalidades de estudo, a dissecção era um tabu cuja violação era quase impensável durante a Idade Média. Este foi o motivo pelo qual se tornaram perfeitamente compreensíveis e inteiramente verossímeis as histórias que viemos a conhecer sobre seqüestros noturnos e furtivos de cadáveres, com a finalidade de realizarem-se experiências de anatomia. Cabe aqui uma reflexão: não há alguma ironia no fato de que essa sociedade - que torturava pessoas, conforme costumávamos pensar, e que até mesmo condenava cadáveres à morte -, precisamente essa sociedade, não admitisse sequer abrir um corpo humano, mesmo morto, para lançar-lhe um olhar objetivo ou objetificante?

É bem compreensível a dificuldade medieval de tolerar as experiências anatômicas: com efeito, abrir o corpo era também bulir no espírito. As primeiras dissecções oficiais se verificaram no início do século XIV e iriam praticamente se 
banalizar após os séculos XVI e XVII. Como tudo naqueles tempos, as primeiras dissecções foram públicas. Ainda assim, constituíam um privilégio de pouquíssimas universidades (Verger, 1990), em geral italianas, que dependiam, contudo, de uma autorização especial do papa. Havia toda uma 'ritualidade' associada às dissecções, consistindo em lentas cerimônias, que se processavam em épocas do ano tidas por especificamente propícias, exorcismos que se estendiam por vários dias, antes, durante e depois do temível cometimento.

Esses ritos tinham claramente a função de aplacar e redirecionar forças perigosíssimas, que estavam na iminência de ser deslanchadas. Além do mais, o ritualismo relativo à dissecção possuía também o sentido, talvez dificilmente imaginável por alguém de nossos dias, de contextualizar de maneira apropriada a ofensa violenta e invasora que, para os parâmetros da sensibilidade medieval, o olhar da dissecção representava. De modo mais específico, a parafernália mística de orações, bênçãos, purificações, comunhões etc. talvez representasse um meio simbólico de prevenir os homens contra a ameaçadora destrutividade que o olhar objetificante silenciosamente prenunciava.

Foi preciso o aparecimento do dualismo cartesiano, distinguindo o corpo e a alma, para que dissecções e olhares objetificantes pudessem ser suportados. Estamos aqui diante de um dos momentos mais intensamente dramáticos da história de nossa sensibilidade moderna, pois, a partir dele, a magia da corporalidade humana se verá crescentemente reduzida à lógica do mecanismo. Em suma: para que o olhar do anatomista passasse a ser tolerado sem suspeitas e para que se superasse a dificuldade de encontrar cadáveres anatomizáveis, foi necessário desencantar o corpo, despojando-o de sua condição de microcosmos.

O próprio Descartes, negando qualquer sensibilidade ao animal, posto que ente desprovido de alma, entregou-se a inúmeras dissecções e vivissecções. Tais meios, em sua opinião, eram suficientemente justificados pelo fim de melhor compreender a 'máquina do corpo' (Le Breton, 1990). Como antecedentes ou conseqüentes desta história, não faltariam personagens que viessem a negar sensibilidade ao corpo de escravos, ou mesmo que chegassem a justificar rotinas torturantes de trabalho em nome de uma suposta maior resistência dos trabalhadores ou dos membros de uma raça particular. Haverá também aqueles que, diante do caráter 'inevitável' da dor, pretenderão desenvolver raciocínios religiosos que a transformem em obrigação, em um dever sofrer.

Não foi fenômeno meramente casual que estes raciocínios coincidissem com momentos críticos de formação do sistema capitalista e que se tivessem, ao menos indiretamente, transformado em instrumentos de repressão de corpos e pessoas. Encarados como produtores, os corpos tenderiam doravante a ser funcional e simbolicamente associados à máquina, cuja trituração ao longo do processo produtivo importaria relativamente pouco, diante da grandiosidade transcendental da razão e do espírito. 
Com a separação cartesiana entre corpo e alma iniciou-se, sobretudo por meios técnicos, um projeto de luta contra a dor. Esta passaria a ser vista como mero indicador de um 'defeito' do maquinismo corporal, passível de ser 'consertado'. Em fins do século XIX, a dor praticamente não comportaria mais qualquer referencial metafísico e seria reduzida a simples assunto neurológico ou farmacológico. Encontramos neste ponto uma operação, histórica e politicamente importantíssima, de separação do sensível e de afastamento entre corpo e dor. Muito do que somos hoje está contido neste processo de desvinculação.

Esta disjunção é de tal maneira importante para alicerçar a ideologia de nossa visão de mundo, que sequer cogitamos de lançar algum olhar crítico sobre os pressupostos e sobre os conteúdos do projeto mais amplo de que é apenas um componente. No entanto, é necessário lembrar, no mínimo, que, entre outras coisas, este distanciamento entre o corpo e sua dor foi (é) um exercício e uma tentativa, em grande parte bem sucedidos, de expansão por meios técnicos dos antigos e realistas limites de exploração do homem pelo homem. Um exercício e uma tentativa que têm consistido em forcejar a tolerância do corpo, por meio de analgésicos, anestésicos, calmantes, estimulantes, fortificantes, em vez de modificar as condições de vida. Tais limites foram outrora, de algum modo, demarcados por fronteiras naturais que respondiam diretamente às agressões - barreiras que, em algum momento, fatalmente gritariam um basta! contra a exploração.

No século XVIII, a dessacralização do corpo já seria relativamente rotineira. Segundo Michel Foucault, "nenhuma penúria de cadáveres, nada de sepulturas violadas ou de missas-negras anatômicas; estamos plenamente na era da dissecção" (1978:126). Não necessitamos ir muito longe para descobrir que os primeiros a terem sido anatomizados foram exatamente os condenados, especialmente aqueles de alguma forma passíveis de tortura. Depois, foi a vez dos indigentes, dos pobres, daqueles que pagavam, com a exposição de suas vísceras, a atenção que receberam de instituições públicas de saúde. Obviamente, os reis, os bispos, os potentados sempre conseguiram escapar a semelhante destino.

A invenção da dicotomia cartesiana corpo/alma constituiu condição preliminar para o entendimento de que algo da existência fosse descartável. Tal dicotomia foi premissa indispensável para se chegar a conceber que alguma coisa do humano, ou mesmo qualquer fração do mundo, pudesse ser considerada como resíduo, sobra. Na visão cartesiana, o corpo não passava de um cadáver e o próprio Descartes em suas Méditations foi bem explícito nesta comparação: 'corpo' não é senão aquilo que sobra da vida de uma alma.

No lado oposto dessa concepção, no mundo medieval, como estamos vendo, espírito e matéria, corpo e alma não se separavam. Nada era verdadeiramente espírito, nada era verdadeiramente matéria. Esta é a razão por que, de um modo geral, tornava-se pouquíssimo provável que na mentalidade e na sensibilidade me- 
dievais coubesse uma idéia como, por exemplo, a de 'lixo' - isto é, uma noção de que houvesse dejetos de objetos, uma percepção de alguma espécie de 'resto' da vida destes. Mais especificamente, e ainda com muito mais plausibilidade, o corpo na cosmovisão medieval jamais poderia ser considerado como um dejeto. Nem lixo do espírito, nem dejeto dos objetos. Nada disso existia na Idade Média.

O resultado prático dessa inexistência conceitual é que uma estranha convivência acontecia. A mentalidade medieval exigia a incorporação concreta - para nós de difícil deglutição - do perecível. Até o cadáver que apodrece tinha lugar nesta coabitação, o que se pode reconhecer no realismo da pintura e da escultura, que reproduziam vermes e decomposição. Mesmo bastante tarde no século XVI, os túmulos são adornados com imagens de cadáveres nus, com mãos enclavinhadas e pés hirtos, boca aberta e ventre cheio de vermes. A dança dos mortos, no mesmo sentido, não foi apenas pintada e gravada. Foi também encenada. Caveiras e mortos eram amontoados e jaziam à vista de todos, obedecendo a um projeto estético. A imaginação do tempo convivia com estes temas, para nós insuportáveis. Não havia meios culturais de os descartar.

Existia uma positividade neste 'insuportável'. Ao contrário do que seríamos tentados a supor, este modo de ser não correspondia a qualquer condenação a que os medievais devessem passivamente se resignar. Também não se tratava apenas de mera convivência de temas imaginários. Era algo querido voluntariamente, algo pelo qual até mesmo se competia, acirrada e concretamente. Vivos e mortos se entrelaçavam em contínua e constante vizinhança, nos tempos medievais, por ativa opção dos primeiros.

Sabemos que na Idade Média os cemitérios situavam-se idealmente dentro das igrejas. Na prática, apenas os poderosos conseguiam para si a melhor fração desse espaço limitado, situando-se o mais próximo possível da relíquia do santo. Para os comuns cabia o cemitério adjacente, um dos lados do qual era sempre uma parede do templo, interna ou externamente. De qualquer forma, era nas igrejas que os cadáveres de ricos ou pobres encontravam suas moradas.

Sabemos também que as igrejas - junto com seus cemitérios - eram o centro da vida comunitária nos tempos medievais: aí aconteciam as proclamações, aí se encontravam os casais, aí as pessoas faziam a feira, aí os casamentos e batizados tinham lugar, aí ficava o forno comunal de pão, aí se realizavam as festas... A vida se dava, enfim, em torno desses corações comunitários que eram as igrejas com seus cemitérios, a tal ponto que, com freqüência, as palavras 'igreja' e 'cemitério' acabavam usadas intercambiavelmente (Ariès, 1975).

Ocorre que eram coletivas as sepulturas. Pouquíssimos na Idade Média podiam se dar ao direito ou à aspiração de possuir uma sepultura individual. Do mesmo modo, pode-se também dizer que eram raríssimos os que se viam condenados a um túmulo solitário. As exceções do primeiro tipo normalmente ficavam por conta de representantes da cultura 'oficial': nobres de alta estirpe, magistra- 
dos, membros do alto clero, os quais normalmente partilhavam com seus familiares uma sepultura que hoje chamaríamos de individual, e em geral acabavam enterrados dentro das igrejas. Aos comuns, amplamente majoritários, destinavamse as sepulturas coletivas, situadas no cemitério adjacente ao templo. Tais sepulturas coletivas ficavam meio abertas até serem preenchidas - e tal fato deve ser muito vivamente marcado: se na Idade Média a igreja com seu cemitério constituía o centro da vida social e comunitária, isso implicava que essas sepulturas coletivas semi ou inteiramente abertas fossem também, e em medida significativa, o núcleo da vida coletiva.

É claro que tal convivência só se tornou possível porque os sentidos de morte e de vida eram completamente outros durante a Idade Média. Vida e morte, vivos e mortos absolutamente não tinham, nos tempos medievais, uma muralha a separá-los. A vida deveria continuar depois da morte, a morte começava antes da vida. Não era típico do cenário medieval o quadro fixado pela iconografia posterior, em que se figura a morte de alguém procurando retratar o momento preciso em que o homem sai de um mundo para ingressar em outro. A concepção predominante de morte era a de que esta é um ato de vida, um sono. Morrer era dormir.

Dormir até o dia do Grande Despertar, ocasião em que praticamente toda a comunidade humana ressurgirá - de corpo e alma - de seus túmulos particulares ou coletivos, para continuar a vida em maior proximidade do Criador, dos mártires, dos anjos, dos santos... O sono da morte representava apenas uma espécie de espera pelo dia do glorioso reerguer coletivo, grande festa comunitária de que deveriam estar excluídos, talvez, apenas os suicidas, os hereges, os regicidas, os sacrílegos.

Em nossos dias, a ressurreição da carne não representa mais do que uma simples frase, situada na contramão do catecismo oficial e esquecida em meio a uma oração cada vez menos recitada. A Idade Média foi, todavia, tempo em que reinava sobre todos e com todo o fervor o "creio na ressurreição da carne". A iconografia registrou esta fé e esta convivência entre vivos e mortos, entre vida e morte, até festivamente, em imagens que retratavam homens dançando com cadáveres que se desfaziam. Tal celebração tem um sentido que hoje já não mais alcançamos: a putrefação é fértil e fertilizadora, a decomposição é geradora de vida (Thomas, 1991).

Para a sensibilidade medieval, a vida nascia do que consideramos 'fedor'. A putrefação era continuidade da vida, húmus. Daí a incorporação não problemática do perecível pelo cotidiano, até mesmo dispondo-o dentro de uma ordem e obedecendo a um projeto estético - do que os ossuários, com suas tíbias e crânios ordenadamente dispostos, não deixam de ser um bom exemplo. Tudo o que perece, assim, era incorporado, não excluído. A decorrência lógica era que qualquer idéia de terminação resultaria semioticamente neutralizada nessa cultura.

Isto quer dizer que aquilo que chamamos hoje de 'lixo' não constituía coisa a ser banida, expulsa ou jogada fora. O lixo era jogado ali mesmo ou nas imediações. Daí o aspecto de amontoamento das cidades medievais, que tanto deveria 
perdurar na história. Daí o aspecto de sujeira das cidades, que não se transformaria senão sob as mais duras pressões. Daí o fato de porcos, cães e abutres se terem transformado nos verdadeiros agentes ecológicos do Ocidente. Daí também aquelas cidades com seus matadouros e sangue escorrendo pelas ruas e pelos córregos, com as gorduras das cozinhas lançadas em quaisquer partes, com as carcaças apodrecidas de animais, com os restos de comidas, com as fezes, os escarros, as secreções, feitos não importa onde e lançados pelas janelas... Todos conviviam com tudo isso. Não há registro de época apontando alguém que se incomodasse com o mau cheiro desses dejetos, nem mesmo que reclamasse de uma vizinhança inoportuna com cadáveres.

Em outras palavras, o medieval foi um tempo em que as condições gerais da vida cotidiana configuravam uma espécie de mistura de 'insuportáveis', consoante o ponto de vista de nossa sensibilidade contemporânea. Dado isto, aquele mundo amalgamado, feito de coisas empilhadas, entrelaçadas, misturadas, deveria ser como que desempilhado, à medida que triunfavam os poderes já esboçados pela cultura oficial. Deste modo, a cultura da elite foi tentando romper com aquela visão de mundo segundo a qual tudo se ligava a tudo. Para isso, foi fazendo uso de seus educadores, higienistas, agentes ecológicos... engajando-se em um projeto histórico que já dura mais de mil anos, embora ainda pareça muito longe de terminar.

É claro que a Igreja sempre viu com maus olhos tudo o que fosse pagão, tudo o que lembrasse esse passado bárbaro, que se contrapunha a seus preceitos oficiais. Na prática, não obstante, viu-se obrigada a transigir por muitos séculos, porque esta maleabilidade era o único caminho pelo qual seus pregadores poderiam desenvolver uma linguagem e uma estratégia de comunicação capazes de atingir as pessoas com algum sucesso. Ainda assim, mais cedo ou mais tarde, aquele mundo em que tudo se fundia deveria ser fragmentado. Categorias que se interpenetravam deveriam resultar em oposições irredutíveis, gerando separações e contradições impensáveis nos tempos medievais.

A vida passará a adquirir sentido mediante contraposições e dicotomias: entre o mundo do natural e o do sobrenatural, entre o do subjetivo e o do objetivo, entre o da realidade e o da imaginação, entre o do verdadeiro e o do falso, entre o da sociedade e o do indivíduo, entre o da natureza e o da cultura. Aquele amálgama, aquela integridade do universo medieval, será contínua e cada vez mais profundamente fracionada, para dar lugar à lógica do 'cada coisa em seu lugar'. Ponto fundamental para nosso raciocínio, é essa lógica de segregações que doravante atribuirá sentido ao mundo, ditará os princípios que vão presidir as mentalidades e sensibilidades posteriores e que deverão resultar na nossa ciência, na nossa etiqueta, nosso meio ambiente, nossa resistência, nossa postura corporal... 


\section{4 \\ Seriedade e Riso}

As últimas páginas podem ter reforçado a imagem estereotipada de uma lúgubre Idade Média. Afinal, que mais poderia ter invocado, à nossa sensibilidade de homens do século XX, o quadro desenhado, composto por todas essas coisas que nos agridem no que temos de mais caro? O lixo nas ruas, as sepulturas abertas, os cadáveres, os vermes proliferando, os abutres, os porcos, as lamas, os maus cheiros... Tudo isso configura uma espécie de avesso do que queremos ser. Tudo isso encarna o contrário do que consideramos razoável. Tudo isso materializa até mesmo o inverso do que pensamos ser humano. Precisamos, entretanto, fazer um imenso, um supremo esforço para corrigir esta impressão - trabalho para o qual há um único caminho: tanto quanto possível, colocarmo-nos na posição do ser humano medieval, entrar na sua lógica e apreciar, sobretudo, o clima, a atmosfera em que se dava o modo existencial que tão negativamente nos afeta.

Um dos problemas mais delicados na análise das questões relativas à sensibilidade corporal talvez seja o de como lidar com um etnocentrismo que não se limita a ser apenas cognitivo, isto é, o desafio representado por um etnocentrismo que termina por ser eminentemente visceral. Quando falamos das emoções, das decisões, dos raciocínios... em geral postulamos implicitamente - e não há muito como fugir a isso - um 'Homem'. Este 'homem' costuma ser, na verdade, nós mesmos. Pensando falar das emoções do 'Homem', com mais força ainda quase sempre nos iludimos e, de fato, é às nossas próprias emoções que fazemos referência, sem disso nos darmos conta. Nesse sentido, ainda não conseguimos nos livrar do mesmo problema que afligiu Lucien Febvre há várias décadas, quando decidiu estudar o problema da sensibilidade na história: afinal, pergunta-se, "como poderão os historiadores compreender os homens de outrora, com uma psicologia saída da observação dos homens do século XX ?" (1987:60).

As danças macabras, por exemplo, em que vivos e cadáveres se divertiam juntos, continham conotações exatamente opostas à sisudez mórbida que lhes costumamos associar. Elas exprimiam - para a nossa perplexidade - exatamente a continuidade alegre entre a vida e a morte, entre o composto e o decomposto; expressavam a descontração da inseparabilidade entre vivos e mortos, entre espí- 
rito e matéria. O personagem que dançava não reproduzia absolutamente uma morte, mas um cadáver, isto é, um homem vivo tal como ele existia em sua inteireza, tal como se integravam agora e porvir.

Tratava-se de uma dança com os mortos, não de um bailado com a morte. Lembrava a fragilidade das coisas terrenas, ao mesmo tempo em que as valorizava. Exibia o ridículo da vaidade e das pretensões de superioridade, nivelando todos os estratos e todos os ofícios. Entretanto, não representava de modo algum uma espécie de consolação contra o não-sentido de morrer, nem mesmo uma inconformidade contra a ausência dos que morreram. É extremamente importante termos em mente que esta prática (como as demais anteriormente mencionadas) continha uma dimensão lúdica e ocorria em um contexto no qual as pessoas sobretudo as dos segmentos mais pagãos e populares - acreditavam emocionada e fervorosamente no princípio da ressurreição da carne.

Sem reduzir o impacto que toda alteridade comporta, a admissão intelectual desse princípio permite alguma aproximação à idéia de que, nessas práticas, os homens medievais celebravam de um modo alegre, pois que desprovidos das razões de nossas angústias, a inexistência de solução de continuidade entre decomposição e recomposição, decadência e regeneração... Contudo, não se trata apenas de entender uma alegria descontraída. Huizinga já havia chamado a atenção para o fato de que "alguém de nossos dias teria dificuldade de entender a emotividade extraordinária da alma medieval". Pois bem, em nenhum outro lugar esta emotividade exacerbada se manifestava de maneira mais vibrante que na fé. E o fervor da fé removia montanhas na sensibilidade. Fazia que fosse lúdico o clima em que se desenrolavam as cenas que hoje nos horripilam. Fazia também que essas danças tivessem caráter festivo, associado à alegria, aos banquetes, às bebedeiras, às orgias...

Mikhail Bakhtin (1987) se aventurou a decifrar os surpreendentes mistérios da festividade medieval. É impossível não retornarmos transformados da viagem que nos propõe. Com ele aprendemos que a Idade Média era totalmente impregnada de uma visão carnavalesca do mundo. Por causa desse modo de olhar, o universo ficava inteiramente liberado de tudo o que pudesse haver de terrível e de atemorizador. A irreverência do olhar carnavalizador transformava o ameaçador em "inofensivo, alegre e luminoso". Tudo o que seria terrível e espantoso no mundo habitual se transformava, por obra do carnavalesco em "alegres espantalhos cômicos".

Assim, o medo, expressão extrema de uma seriedade unilateral e estúpida, era derrotado, na visão carnavalesca, pelo riso. Por esta razão, os cadáveres, o lixo, as feridas etc. acabavam por configurar um mundo no qual, ao invés de separação de si, o homem encontrava-se consigo mesmo. Talvez se tivesse mais temor à vida que à própria morte - pois, segundo Bakhtin, "ao morrer o mundo dá à luz". Os resíduos comportavam, portanto, a mensagem reconfortante e alegre de que tudo o que existia seria destruído para se renovar imediatamente. Os restos informavam que tudo estava impregnado da alegria da mudança e da renovação. 
Para o homem medieval, no entanto, isso não se dava sob forma de emoções abstratas, internas, secretas, remotas. Materializava-se como algo que se apossava da integridade existencial do ser humano, de seus pensamentos, de seus sentimentos e, sobretudo, de seu corpo.

Entre as figuras medievais de corpo a que Bakhtin dá especial atenção estão as "velhas grávidas" (1987:23): nelas, os signos da decrepitude e da decadência se associam à representação de uma imensa barriga, a sinalizar que a anciã estava prestes a dar à luz. Estas imagens pretendiam expressar comicamente a recusa de antinomias entre vida e morte, degenerescência e florescimento, início e fim, pois esses termos se amalgamavam todos em um mesmo corpo, cujo rosto ria. Nas "velhas-grávidas-que-riem" encontramos dois corpos em um. Estes corpos exprimem a vida nova e a vida velha, a degeneração e a regeneração em suas mútuas interpenetrações. O corpo disforme e desestruturado da velhice contém a corporalidade ainda embrionária da nova vida. Desse modo, vida nova, vida velha, tudo é um, tudo é vida. A vida se revela em seu curso ambivalente e interiormente contraditório. Mostra-se nuamente como é. Como um fluxo em que cada minuto vivido é também um passo para a morte.

A festa e a carnavalização estavam por toda parte. Estavam nos campos, nas cidades, nas casas dos pobres, nos castelos, nas igrejas. As festividades eram o contexto de muitos conflitos, mas, acima de tudo, o momento da ritualização, da localização e do controle social deles. Por exemplo, eram ocasiões que rapazes aproveitam para violar meninas; momentos em que mulheres abandonadas por seus maridos eram sexualmente atacadas; épocas em que maridos ausentes tinham suas esposas visitadas... As festas eram instantes em que os excessos permitiam que aflorassem rivalidades, em que transgressões degeneravam em desentendimentos. Contudo, eram também circunstâncias propícias para as soluções amigáveis, para as confraternizações, para o fortalecimento dos laços de solidariedade. A festividade era simultaneamente todas essas coisas - encontros e desencontros, comemoração e conflito -, mas sempre matizada por um estilo característico, estilo governado pela alegria e pelo transbordamento.

Foram múltiplas as manifestações da cultura popular, nesse seu lado festivo. Havia diversas modalidades de ritos e espetáculos, tais como festejos carnavalescos e obras cômicas representadas em praça pública; jogos verbais, como desafios e paródias; estilos de relacionamento jocoso, envolvendo vocabulário chulo, insultos verbais, gestualidade obscena, juramentos blasfêmicos, saudações irônicas... Havia os carnavais propriamente ditos, com todos os atos e ritos cômicos que o compunham e que ocupavam um lugar muito significativo na vida do homem medieval - envolvendo diversos atos e cortejos, semelhantes a complicadas procissões que enchiam as praças e as ruas.

Havia as festas dos tolos, as festas do asno, a ridicularização do rei, as abadias de desgoverno, os charivaris, o riso pascal, o riso do natal, as festas de padroeiros, as celebrações dos solstícios, do ano novo, do dia de reis, dos santos, da páscoa, 
dos casamentos... Eram todas ocasiões marcadas pela irreverência (Davis, 1990; Heers, 1988), pela insolência em relação a tudo. Ocasiões em que as pessoas saíam pelas ruas praticando maluquices, tolices e bobagens. Situações, igualmente, em que alguns, de preferência membros do estrato superior, eram escolhidos para serem ridicularizados pelas besteiras e estultícias que houvessem praticado, pela reputação ruim que tivessem adquirido, ou ainda por suas maneiras eventualmente criticáveis de tratar as outras pessoas.

A festa dos bobos, que ridicularizava as instituições, que ironizava o sério, que fazia de tudo uma brincadeira, transformando a vida e a morte em fruição lúdica, talvez seja um bom exemplo do que estamos evocando. Nela, em lugar de incenso, os padres usavam excrementos; em vez de benzer com águabenta, abençoava-se com urina. Terminada a missa, saía-se em uma espécie de cortejo, durante o qual os sacerdotes eram transportados em uma carroça carregada de excrementos, onde afundavam as mãos para retirar porções que atiravam sobre a população - feito que alternavam com o gesto de urinar escancarada e debochadamente por cima das pessoas. As festas dos loucos, por outro lado, envolviam inversões paródicas, mascaradas, danças obscenas, incitamento à volúpia, desnudamento, glutonaria e embriaguez no próprio altar, traduzindo-se com constância no regozijo particularmente desenfreado do clero. As festas do asno, ainda, evocavam a fuga de Maria e do Menino Jesus do Egito. Contudo, o centro da festa era exatamente o jumento. Nas missas associadas a essas festividades, o padre zurrava três vezes ao final, obtendo da parte dos fiéis, em lugar do 'amém!', outros três relinchos.

Além disso, quase todas as festas, especificamente religiosas ou não, possuíam um aspecto cômico, popular e público, consagrado pela tradição - como as festas do templo, envolvendo feiras e cortejos, gigantes, anões, animais amestrados, eleições de reis e rainhas de faz-de-conta... A própria representação dos mistérios se dava em ambiente carnavalizado, o que acontecia com as festas agrícolas (como a vindima, que também se celebrava nas cidades) e ainda com os ritos e cerimônias civis da vida cotidiana, sempre acompanhados pelos risos e pelas brincadeiras. Bobos e bufões assistiam quase sempre às funções do cerimonial sério, parodiando e arremedando irreverentemente os atos que o constituíam.

Não se tratava de mera representação teatral, de uma encenação puramente artística apenas. Já fiz referência ao fato de que o especificamente artístico não existia na Idade Média. É óbvio que havia uma relação extraordinariamente íntima entre a teatralização e a carnavalização medieval. Mas esta relação era de entrelaçamento: o carnaval medieval se situava nas fronteiras entre a arte e a vida. Era uma festa que a população oferecia a si mesma. Na verdade, o carnaval era a própria vida representada. A vida apresentada por cada um a si mesmo e aos outros, por intermédio dos elementos característicos da encenação. Como vida carnavalesca, não havia, nesse cenário, distinção entre atores e espectadores. Não havia palco. Ninguém 'assistia' ao carnaval. Ninguém se exterioriza como um 'espectador' da 
vida social. Ninguém a podia observar como se dela não fizesse parte. Todos apenas viviam o carnaval, representando o espetáculo da vida para si mesmos e para os outros. Não havia fronteiras, todos eram simultaneamente sujeitos e objetos da carnavalização - se estes termos fazem algum sentido, quando empregados do modo como os estou empregando.

Ao contrário das festas oficiais, o carnaval se caracterizava pela abolição das relações hierárquicas, tentando neutralizar e ridicularizar as insígnias marcadoras de distinções sociais. Sua finalidade era a consagração da igualdade, a celebração da comunidade e da fusão de todos com todos, de tudo com tudo, pela liberação do contato livre e familiar, pela abolição das barreiras cotidianas. O carnaval era um interessante contraponto às hierarquias formais da sociedade feudal, com sua extrema compartimentação em estratos e corporações.

É importantíssimo ter em mente esta dimensão dionisíaca, pois a faceta ordenada e hierarquizante - que não se tornou relevante senão entre os séculos XIII e XV (Bloch, 1968) - foi o que permaneceu prioritariamente no imaginário das sociedades 'modernas' e 'democráticas' a respeito da Idade Média. Esta escolha esqueceu o fato de a nobreza ter sido um acontecimento relativamente tardio no Ocidente e suprimiu, quase sempre com finalidades ideológicas, a dimensão do riso e da gargalhada dessa Idade Média carnavalizadora, sempre presente nos cotidianos. Relegou-se a um plano insignificante a Idade Média das festividades carnavalescas, que, nas grandes cidades, segundo Bakhtin, "chegavam a durar três meses por ano no total" (1987:11).

O desdém carnavalesco pela hierarquia e pela separação é apenas uma das manifestações possíveis do princípio fundamental da 'lógica ao contrário' ou ao 'avesso'. Por este princípio, fazem sentido as permutações constantes entre o alto e o baixo, entre o estruturado e o decomposto, entre o interior e o exterior, permutações que terminam por desenhar um mundo invertido. Era exatamente essa lógica carnavalesca o que dava sentido aceitável, na mentalidade e sensibilidade medievais, à mistura de tudo com tudo, à convivência e ao amontoamento, à presença do que chamei de 'coexistência de insuportáveis'. De acordo com essa lógica, vivos e mortos se permutam, vida e morte se eqüivalem, putrefação e regeneração dão no mesmo.

A vida do dia-a-dia transcorria em cenários por si mesmos festivos. Eram poucas as portas, o cotidiano escoava a céu aberto, os encontros se davam nas tabernas, nos mercados e nas praças, ambientes efervescentes e festivos por excelência, muito mais ligados ao consumo e à consumação do que ao trabalho e à produção. As festas praticamente tomavam conta das preocupações da vida medieval: passava-se boa parte do tempo com lembranças e comentários sobre a última festa, ou então com preparativos para a seguinte. O direito de comparecer às festividades não suportava privilégios, pois todos estavam tacitamente convidados para batizados, casamentos, funerais, comemorações de tosquia, de 
colheita. Os 'convidados' compareciam como se possuíssem um direito automático a tal. Este direito, contudo, não excluía obrigações, pois não comparecer configurava ofensa tão grave quanto esquecer de convidar (Thomas, 1991).

Além disso, a bebida fazia parte integrante do dia-a-dia da sociabilidade. Os testemunhos sugerem que o consumo era enorme. Bebia-se para conversar, conversava-se para beber. Não havia transação comercial que não se fizesse acompanhar de uns goles. Os canecos não se excluíam tampouco dos campos e das oficinas. Desde longa data, os pregadores medievais levantavam queixas quanto aos trabalhadores se embebedarem rotineiramente, pelo menos uma vez por semana. Na Inglaterra (Thomas, 1991), visitantes estrangeiros registraram que os artesãos não deixavam passar um dia sem uma visita à taverna. A cerveja era bebida de preparo fácil, caseiro e barato, constituindo um ingrediente básico na alimentação de todos, adultos ou crianças. Poderíamos ainda falar da ingestão de vinhos e do consumo crescente dos destilados. Bebia-se sempre, nos cenários mais reservados ou nos ambientes públicos.

O mais público dos cenários medievais era a igreja. A maior parte das festividades ocorria exatamente aí, seja no interior do templo, seja em suas adjacências. A igreja era, assim, o território em que se davam as coisas mais profanas. É importante relembrar, contudo, que o catolicismo medieval ainda se mostrava em grande medida uma religião pagã, posto que no paganismo os deuses se divertiam e os demônios também apresentavam uma certa bonomia. Fastas ou nefastas, as divindades encontravam no lúdico o mesmo prazer que os homens.

Para compreender estas palavras, é preciso termos em mente o fato de hoje apresentarmos uma certa tendência a confundir a emoção do divino com uma gestualidade formal e com uma severa solenização. No entanto, a igreja nem sempre foi o lugar que agora conhecemos: aquele de separação radical entre o sagrado e o profano; aquele onde não se fala senão em voz baixa; aquele onde se inclina a cabeça em sinal de respeito; aquele em que se deve ajoelhar para expressar inferioridade... A própria cruz não era mostrada como um instrumento de suplício, nem Cristo era a imagem do sofrimento. Ao contrário, eram, antes do ano mil, fundamentalmente os emblemas alegres de um triunfo, os símbolos de uma feliz vitória de norte a sul, de leste a oeste, sobre forças ameaçadoras. Apenas por volta de 1100, a cruz começou a ser exibida com uma significação nova e o corpo de Cristo começou a aparecer triturado e evocando dor (Duby, 1988b).

A igreja medieval era lugar usado para os propósitos mais leigos. Local onde se permitia aplaudir os sermões, em que se dançava e cantava. Nos tempos medievais não existia diferença entre músicas profanas e músicas sacras, de modo que as melodias que se cantavam na igreja eram as mesmas que se entoavam no dia-a-dia, em outros locais e atividades. Longe ainda dos tempos em que os regulamentos dos sínodos recomendariam aos bispos que não visitassem prostíbulos e tavernas, a igreja da Idade Média era ainda um ambiente que os animais freqüentavam e onde faziam tudo o que costumavam fazer em outros contextos. 
A ambiência medieval era de extrema familiaridade com as coisas sagradas. Coerentemente, o templo era também lugar de comidas e bebidas, de namoros e pileques. Em algumas paróquias era costumeiro comer e beber à mesa de comunhão. Comungar comendo, literalmente: participando de uma ceia, não apenas ingerindo uma hóstia inodora e insípida. A iconografia nos conta histórias nas quais aparecem imagens que representam Jesus distribuindo vinho a pessoas que se embriagam. As metáforas dos discursos remetem a pessoas ébrias do 'leite de Maria' - cenas que oferecem uma conotação totalmente báquica das relações entre homens e divindade, sobretudo pelo recurso à remissão constante da segunda à escala dos primeiros e pela humanização de tudo o que é sublime.

Havia mesmo alguma expectativa tradicional de que semelhantes acontecimentos viessem à luz. Não se corre o risco de exagerar a presença de festas do amor ou de cervejadas nas igrejas, em ocasiões como a Páscoa e outras festividades do calendário. Fundamentalmente, não havia qualquer insolência em se misturar prazer com religião: as peregrinações o ilustram, pois eram também momentos eróticos, ocasiões para grandes libertinagens; as procissões resultavam com freqüência em cavalgadas grotescas e lúbricas; os jovens sacerdotes tinham o costume de comemorar em prostíbulos as suas primeiras missas...

Para a opinião coletiva medieval, isso não representava qualquer absurdo, tolerando-se, mediante penitências públicas, a prevaricação, o concubinato, o repúdio (Rossiaud, 1991; Heers, 1988). O sínodo de Paris, em 1074, recusou-se a aceitar o celibato dos padres, considerando-o contrário à razão e à natureza humana (Dalarun, 1990). O motivo disso é que não configurava sacrilégio algum mesclar o místico com o erótico, o prazer com a fé. Registremos, entretanto, para não deixar escapar nosso tema principal, que tudo isso acontecia ao lado de sepulturas entreabertas e no envolvimento das visões e dos cheiros que dali emanavam.

Um dos modos fundamentais de manifestação deste espírito zombeteiro era a paródia. Nada escapava ao deboche, à ironia, à brincadeira, à jocosidade. Paródias das formas religiosas: sermões feitos por palhaços em louvor ao roubo, à bebedeira, à loucura, ao adultério; sermões de padres fazendo palhaçadas, parodiando atos criticáveis; paródias do evangelho, do catecismo, do credo, do pai-nosso, da avemaria; paródias dos hinos religiosos, das litanias, dos testamentos (do porco, do corno, do asno, do bêbado etc.); liturgias paródicas (dos beberrões, dos jogadores etc.); paródias dos epitáfios, das decisões conciliares. Paródias, sobretudo, dos mandamentos. Havia ainda vários modos de parodiar as formas jurídicas: proclamações simuladas, julgamentos de faz-de-conta, tribunais de brincadeira, testamentos gaiatos, decretos galhofeiros e assim por diante (Burke, 1989; Bakhtin, 1987).

Como observou Paul Veyne (1992), os deuses das religiões apoiadas nos livros são seres gigantescos, inteiramente superiores ao mundo - o qual, aliás, eles criaram. Esse tipo de deus só existe como ator de um drama cósmico e transcendental, no qual a humanidade põe tragicamente em jogo a dúvida sobre sua salvação. Os 
deuses do paganismo, ao contrário, vivem as suas vidas e não se deixam reduzir a um papel metafísico. Junto com os homens, eles fazem parte do mundo - e esta é a razão pela qual tais formas de relacionamento com a divindade são algo incompreensíveis para nós.

As imagens que se faziam, nesse último contexto, para revelar as coisas divinas, eram elaborações que a nossa sensibilidade dificilmente poderia acolher: por exemplo, Deus apresentado como um glutão insaciável; Deus como um ser que tem fome; Deus como um ente que quer beber e comer continuamente; Deus como alguém que tem uma barriga gigantesca, capaz de devorar os pecados e os erros do mundo. Jesus podia ser comparado a um bêbado que distribui à farta copos de vinho aos profetas, pois o amor divino tem paralelos com a embriaguez. Deus, enfim, nessa maneira de ver, é como alguém que faz as mesmas coisas que os homens.

O cristianismo, desde a Antigüidade, sempre condenou o riso. Sempre rejeitou, em particular, a gargalhada. Sempre fez apologia da seriedade constante. Proclamou em todas as circunstâncias a necessidade do sério, em sinal de contenção, de dor e de arrependimento pelos pecados. Sabemos todos o quanto o cristianismo oficial sempre preferiu destacar o sofrimento, pelo que este contém de expiação. Para esta religião, o riso e as burlas não provêm de Deus. Emanam, antes, do diabo. Daí serem muito raras, no interior das igrejas, as representações do Deus cristão, esquecido da sisudez habitual, entregue às gargalhadas. São igualmente raríssimas as imagens de santos sorridentes, liberados da fisionomia grave, séria e muitas vezes dolorosa que são obrigados a apresentar. Quanto ao demônio, entretanto... Quem sabe não está embutida nestas concepções uma atitude muito antiga em relação ao prazer?

No princípio da Idade Média, a dimensão orgíaca da cultura-de-todo-mundo penetrava muito profundamente nos círculos religiosos. Os esforços da Igreja com $i$ maiúsculo eram baldados, diante da força da igreja com $i$ minúsculo. A primeira não tinha alternativa, a curto prazo, senão tolerar... Assim, durante muitos séculos, esse núcleo de poder que a Igreja representava foi obrigado a conviver com uma cultura na qual rir não significava correr risco. Antes de se poder proclamar, em alto e bom som, que muito riso fosse sinal de pouco siso, ou que este e aquele não fossem lugar de brincadeiras, imagine-se quanta concessão a Igreja foi compelida a fazer, na atuação de seus pregadores, para conseguir atingir pessoas que não acreditavam no sério e que dele até mesmo desconfiavam! Mais ou menos como os políticos de hoje, que sabem perfeitamente ser preciso colocar um pouco de humor nos discursos para atingir certas camadas do eleitorado, quanto de 'estratégia comunicacional' - teatros, malabaristas, palhaços, imagens grotescas etc. - foram os evangelizadores constrangidos a inventar, simplesmente para terem alguma possibilidade de êxito na transmissão das mensagens cristãs! 
Configurando uma unidade que viria a ser tensa e contraditória, e que até nossos dias ainda não revelou tudo o que tem a declarar, havia, na mentalidade e na sensibilidade do homem medieval, diferenciadamente segundo os tempos e camadas sociais, uma coexistência de duas culturas. O ser humano medieval era um ser de duas mentalidades e duas sensibilidades: nele se enfrentavam o princípio da seriedade, sempre lembrado pelas autoridades e poderosos, e o do riso, durante muitos séculos hegemônico. Sabemos que progressivamente foram aumentando o peso e a força da cultura da seriedade, historicamente limitada, no início, à nobreza e ao alto clero. A mentalidade do sombrio foi, no entanto, gradativamente convertendo para si setores cada vez mais extensos da população, bem como domínios sempre mais numerosos da experiência (Goulemot, 1992). Aos poucos se foram invertendo as relações de hegemonia entre as duas culturas: eis o que a história revela.

Nas palavras de Bakhtin, "o homem da Idade Média era perfeitamente capaz de conciliar a assistência piedosa à missa oficial e a paródia do culto oficial na praça pública. A confiança que gozava a verdade burlesca era compatível com uma sincera lealdade" (1987:82). Dito de outro modo, o respeito e a reverência podiam tranqüilamente conviver com a desconfiança em relação ao sério, com a assimilação deste a intenções más. A hierarquia e a solenidade eram normalmente passíveis de compatibilidade com o ridículo e com o deboche disparados na direção daquilo e daqueles que se acreditavam superiores. Mostravam-se harmonicamente coabitáveis, em um espírito sempre pronto a uma piada; em um humor assassino, sempre disposto a derrubar estátuas de pedestais.

A mentalidade do homem medieval englobava os dois aspectos da vida e do mundo - era a cultura dos bobos da corte (Balandier, 1982; Heers, 1988), a cultura dos bufões habitualmente presentes nas mansões e castelos, não dispensados nem mesmo pelos reis. Os bobos da corte representavam simbolicamente o comparecimento estrutural, no próprio âmago da armadura formal do poder, do elemento irreverente, incrédulo, burlesco. $\mathrm{O}$ bobo da corte era um personagem que tornava as sumidades em figuras grotescas; que transferia as cerimônias e ideais elevados para o plano risível do material e do corporal. O bobo era essencialmente um ator, que não admitia a petulância da superioridade. Ator porque agia. Ator em virtude de representar. Ponto importantíssimo, ele explicitava, no mais íntimo do sério e do poderoso, o ridículo fundamental que estes continham.

O bobo da corte não era uma figura anômala, excepcional. Existia como personalidade institucional, como uma espécie de conselheiro, como um detentor de uma sabedoria específica, capaz de avisar, alertar, denunciar, decifrar, vaticinar, desconcertar... Detinha uma sapiência tão legítima e respeitável quanto a dos astrólogos ou a dos estrategistas militares. Paulatinamente, entretanto, a cultura do riso livre e liberador foi cedendo lugar a uma visão de mundo impregnada de medo, de docilidade, de resignação, de fingimento, de violência, de intimidação, de 
ameaças, de interdições, de exigências, de aterrorizações, de tremores, de contenções... A antiga franqueza em praça pública foi transformando-se gradualmente em mexerico e lavagem-de-roupa-suja em privado. Uma cortina de silêncio e repressão lentamente veio a se fechar sobre o cenário aberto e franco de outrora.

A aversão que a Igreja sempre teve contra o riso e contra a gargalhada recebeu um reforço muito intenso por parte dos reformadores, que mais enfaticamente do que nunca passaram a lançar objeções contra todas as formas de religiosidade popular: milagres, sermões laicos, ritos paródicos e, acima de tudo, festas sacro-profanas, como os dias de santos e as peregrinações. Os reformadores católicos geralmente não chegavam a atacar as formas tradicionais de culto e religiosidade, mas seus excessos. Eram bastante menos radicais do que os protestantes. Estes, por sua vez, queriam usualmente abolir os feriados religiosos, bem como quase todas as festividades. Alguns se opunham tanto à quaresma quanto ao carnaval, festa que Erasmo caracterizou como 'não-cristã', em virtude da licenciosidade e do paganismo que continha. Outros se contrapunham a todos os dias santos além do domingo e faziam objeções até mesmo ao culto de santos (Burke, 1989).

A partir dos reformadores, podemos encontrar duas éticas, ou modos de vida, existindo em conflito aberto e transformadas em rivais. A ética dos reformadores, como já disse, fundava-se na decência, na diligência, na gravidade, na modéstia, na ordem, na prudência, na razão, no autocontrole, na sobriedade, na frugalidade - ou, para relembrar a expressão de Max Weber, era uma mentalidade baseada no "ascetismo mundano". Esta visão de mundo foi cada vez mais entrando em conflito com a perspectiva tradicional, que sempre lhe opôs resistência e que se inspirava radicalmente na espontaneidade e em uma grande tolerância com respeito ao que, para a outra, seria simplesmente 'desordem'. Vale registrar que o conflito entre essas duas maneiras de existir seria extremamente aguçado pela ação ulterior do Estado, franco partidário da primeira, também opositor do riso e da gargalhada. $\mathrm{O}$ entrechoque seria ainda agravado por outro tipo de sério, que emergiria lentamente: o rigoroso e científico (Baeta Neves, 1979).

É preciso levar em consideração que a cultura oficial colocou em nossas mentes a Idade Média dos mosteiros, das catedrais, dos castelos, do alto clero, dos reformadores, dos protestantes, enfim, daqueles em quem o riso e a gargalhada existiam menos, daqueles que eram mais disciplinados ou eram disciplináveis com mais facilidade. É preciso ter em mente que o medieval lúgubre e sério de nossa imaginação proveio exatamente daqueles que primeiro se opuseram ao riso e daqueles que primeiro perderam a capacidade de rir: os literatos, os intelectuais, os cientistas, os doutrinadores, os poderosos...

Estes personagens desenvolveram - sob a aparência de teoria científica, filosófica ou erudita - uma verdadeira ideologia da seriedade. Por meio dessas elaborações intelectuais, que radicalmente omitiam a relativização histórica do riso 
e do humor, procuraram convencer seus públicos de que os fenômenos de riso são fundamentalmente 'transgressões', fatos derivados, acessórios em relação a algo anterior e mais fundamental: o sério.

Tenta-se, assim, fazer-nos esquecer de que o riso é um componente 'inabstraível' da dramatização da existência do homem (Bergson, 1983; Huizinga, 1990; Duvignaud, 1977b). Despreza-se o fato de que o riso é manifestação de uma superabundância do ser. Apaga-se seu caráter de energia extraordinariamente expansiva de que o homem dispõe, por ser o único animal que ri. Os ideólogos da seriedade certamente não se apercebem de que, neste ponto específico, expressam o essencial da visão de mundo do protestantismo e do capitalismo. Não reconhecem que estão reafirmando o fundamental desta ética, que sempre considerou a vida prazerosa como um desvio.

A partir daí, com ar grave - o que é grave - eles se permitiram construir teorias e mais teorias, que em geral não passam de meros mitos em torno do tema "no princípio era o sério e fez-se o riso". O riso ficou, assim, vetustamente desprovido de positividade, deixou de ser essencialmente manifestação de amor à vida e da alegria de viver. Passou a ser simples transgressão de uma regra já existente, liberação de uma pressão anterior, quebra de uma expectativa, fuga de uma realidade, descarga de uma energia psíquica bloqueada... Transformou-se em fenômeno derivado do solene e do sério - e não algo que deva ser estudado "em si enquanto tal" (Propp, 1992). Tornou-se possível, deste modo, submeter o humor e o riso aos circunspectos princípios que regem a sociedade capitalista.

Por este caminho, o riso se transformou em especialidade de alguns, em arte de dizer o indizível. Submeteu-se à lógica da divisão do trabalho (inventaramse humoristas e cômicos profissionais, por exemplo) e ao princípio da localização espacial (fora de certos ambientes, dentro de outros; nos quadrados de charges, não misturados ao noticiário jornalístico sério). $\mathrm{O}$ riso passou a ser situado no tempo (nas horas de lazer, fora dos momentos de trabalho; na infância e juventude, mais que na maturidade). Especializou-se em certas áreas da cultura em detrimento de outras (na publicidade mais que na religião; no íntimo mais que no público; nos homens mais que nas mulheres; na sociedade mais que no Estado). Perdeu a antiga universalidade, que transformava tudo e todos em risíveis potenciais.

A trajetória histórica do carnaval expressa bem esse destino de progressivo silenciamento do cômico e da irreverência. Esses componentes da festa carnavalesca foram desaparecendo à medida que o capitalismo, a Igreja e o Estado se foram fortalecendo. Paralelamente a estes macroprocessos, as festas, sempre menos e menos carnavalescas, cada vez mais se confinaram aos ambientes privados e familiares. Transferiram-se das ruas para os salões ou para áreas predefinidas das cidades; foram repelidas do centro urbano para as periferias. O regozijo carnavalesco transformou-se em mercadoria ao alcance apenas dos que são convidados ou dos que podem pagar o preço dos ingressos... 
Com isso, as metamorfoses da festa procederam também à distinção da estratificação social e econômica, de modo a limitar a confraternização dentro da mesma classe ou a permitir brincadeiras apenas na direção dos superiores para os subalternos. Desta maneira, acabou-se por segregar a festa dos pobres, encaminhando-a para espaços distantes. Além disso, os participantes, cada dia mais cuidadosos com suas reputações individuais, passaram literalmente a esconder a espontaneidade festiva atrás de máscaras. Com freqüência considerável, em parte também para encontrar esconderijo, os foliões passaram a viajar para onde fossem pouco conhecidos ou estrangeiros. Com o correr dos séculos, as festas, principalmente as de explosividade carnavalesca, submeteram-se à tutela policial. Sinal dos novos tempos, passou-se a imaginar que o poder policial trabalharia em função do bom funcionamento da festa, da alegria e da segurança carnavalescas. Não se percebe, entretanto, que 'polícia', em grande medida, é o anticarnavalesco por excelência.

Assim o destino das festas em geral: foram-se limitando em número, em duração, em tipologia, em intensidade e, sobretudo, no que diz respeito à efervescência carnavalesca que continham - pois toda festa, como vimos, era de certa forma carnaval. O carnaval tendeu, onde continuou a existir, a se tornar uma festa específica. Inclinou-se também a se concentrar tanto no tempo como no espaço (em certos dias do ano, em certos momentos de algumas festas, em certos países, em certas cidades, em certas áreas das cidades). Além disso, um autoproclamado refinamento da sensibilidade foi transformando as lamas, fezes e urinas, que se arremessavam, em águas perfumadas, serpentinas, confetes ou moedinhas de chocolate.

Foram necessários muitíssimos anos de transformações na estrutura dos festins carnavalescos para que fossem oficialmente aceitos pelas autoridades - e antes de caírem em um quase-esquecimento. Não foram poucos os soberanos, os santos e papas que se opuseram 'às orgias pecaminosas'. Tertuliano, São Cipriano e Inocêncio II dirigiram-se frontalmente contra o "festim diabólico", chamando-o até mesmo de "maldição dos homens" (Sebe, 1986:24). Apenas no século XV, provavelmente movido pelo sucesso popular da festa, o papa Paulo II incorporou-a ao calendário cristão. Todavia, isso aconteceu à custa de uma inversão quase total de seu genuíno espírito pagão.

Aqui e ali persistiu no continente europeu algo de carnavalesco, em pontos mais ou menos isolados e que muito pouco, ou quase nada, retiveram do antigo transbordamento - pois, como Philippe Ariès observou, "as festas mais coletivas foram as que desapareceram mais depressa" (1978:153). Um levantamento efetuado em duas obras sobre festas francesas, por Maria Isaura Pereira de Queiroz (1992), mostra que o carnaval se realiza em quarenta e uma das aglomerações urbanas do país. Trata-se, contudo, de um carnaval de pequenas cidades. Destas, vinte e duas têm até dez mil habitantes e as dezenove restantes não ultrapassam os cinqüenta mil. Das vinte e três maiores cidades da França, não incluídas nessas quarenta e uma, somente duas festejam os dias gordos: Estrasburgo e Nice. 
Em Colônia, na Alemanha, há ainda um pálido carnaval, com festas em boates, desfiles pelas ruas, em que pessoas vestidas como se fossem nobres lançam, do alto das carruagens que as transportam, moedas douradas de chocolate para as que assistem ao espetáculo. Há algumas fantasias, em geral caricaturais; há críticas a personalidades locais. Há belas cervejadas. Há ritos de licença, como o do Weiberfastnacht, em que as mulheres, uma vez por ano, podem realizar tudo o que querem e podem sair pelas ruas equipadas com tesouras, para cortar as gravatas dos homens que vão encontrando - simbolismo, aliás, que qualquer psicanálise de botequim pode decifrar.

Tive oportunidade de caminhar pelas ruas de Colônia, bem cedo, na manhã posterior aos folguedos. Um fato chamou particularmente minha atenção: as autoridades já se haviam apressado em eliminar todo indício de turbulência. Coisa parecida vem acontecendo nos últimos anos no Rio de Janeiro, em Copacabana, na manhã seguinte às festas de réveillon, que reúnem multidões de moradores da cidade e de turistas para comemorar a passagem do ano e fazer oferendas a Iemanjá (embora os velhos macumbeiros, que ao menos parcialmente inventaram esta festa, já tenham sido quase completamente expulsos). Terminado o espetáculo, no Rio de Janeiro ou em Colônia, o exército da assepsia urbana - exibindo competência raramente constatável nos demais dias do ano - de imediato prepara um porvir sem quaisquer traços de excesso.

Uma história do carnaval, infelizmente, é uma narrativa de como esta festa vem perdendo exatamente o seu lado carnavalesco, mesmo que isto se dê em nome de um gigantesco espetáculo estético. No caso do Rio de Janeiro, considerado o lugar do carnaval por excelência, esta história é um relato dos caminhos pelos quais o evento se está transformando em sinônimo de desfile de escolas de samba, em detrimento de outras formas de carnaval. Isto significa que o festival se está tornando talvez antagônico ao genuíno espírito carnavalesco.

O grande desfile carioca não é somente um megaespetáculo que aparta atores, espectadores e, cada vez mais, telespectadores. Além de concentrar as atenções carnavalescas apenas nos principais grupos em que as escolas de samba foram hierarquizadas, o desfile representa também um concurso, uma competição. Na verdade, ele constitui uma batalha impiedosa entre as escolas: logo após a festa, as urnas contendo os votos de um certo número de jurados serão abertas, as notas serão anunciadas cerimonial e quase colegialmente, a contagem final designará a grande vitoriosa do ano, escalonando vencedores e perdedores, promovidos e rebaixados. Ora, se uma das características primordiais do carnaval da Idade Média era exatamente a abolição das hierarquias, podemos então perguntar: o que resta de carnavalesco nisso?

Existe um outro componente da encenação com peso ainda menos carnavalesco: a disciplina que deve ser revelada pelo enorme número de dançarinos no decorrer de suas evoluções. O tempo do percurso é draconianamente contado em 
minutos. Um relógio digital (haverá algo menos carnavalesco?) figura em lugar de destaque, como se fosse o grande poste totêmico da festa. Por isso, entre outros fatores, os movimentos da multidão, gigantesca e resplandecente, são minuciosamente regulamentados e vigiados: o mínimo deslize pode redundar em perda de tempo - isto é, de pontos -, resultando em desclassificação da escola e em prejuízos financeiros (porque, neste novo carnaval, tempo também é dinheiro). Por conseguinte, não raro os diretores das alas regem as evoluções de seus contingentes, os movimentos e a velocidade com que devem ser executados, gritando com voz de comando e usando apitos, como se fossem sargentos ou árbitros esportivos. Em busca dessa disciplina, não se exclui a obrigatoriedade de presença aos ensaios mais próximos da data da festa e mesmo o emprego de violência física.

Vale a pena registrar que numerosos participantes do desfile são profissionais remunerados (a porta-estandarte e o mestre-sala; certos passistas; certos figurantes, entre outros). Por outro lado, alguns são destaques em virtude de terem feito um pagamento, lícito ou não. Isto sugere o quanto o carnaval novo já se embebeu de produção, investimento, rentabilidade, adequando-se à estrutura de poder que o gera. Esses pagamentos costumam ser justificados como uma remuneração compreensível por razão de um 'trabalho' prestado - mesmo que isso aconteça sob os protestos dos que agora são chamados de tradicionalistas.

Enquanto isso, muitos daqueles diretamente responsáveis pela festa, por participarem da feitura das pequenas coisas sem as quais a grandiosidade do evento não seria possível - costureiras, bordadeiras, carpinteiros, pintores -, ironicamente não têm os meios sequer de se tornarem espectadores. São barrados no baile, quer porque os preços exorbitantes dos ingressos excedem seus recursos, quer porque as arquibancadas são construídas de modo a impedir a visão do interior do palco para quem se esforça por admirá-lo da rua, antigo domicílio da alegria.

Torna-se, assim, este novo carnaval, uma festa para os altos estratos e para os turistas que podem pagar pelo 'maior espetáculo da Terra'. Os ricos, muito luxuosa e comodamente estabelecidos em seus camarotes estratosfericamente caros, lá do alto aplaudem o cortejo de modo fervoroso. O luxo das fantasias, das alegorias, dos carros, reflete o consumo ostentoso dos que estão inseridos plenamente na sociedade capitalista industrial e de consumo. Nesta cerimônia, as elites não fazem mais do que confirmar, para si mesmas e para todos, a localização que ocupam na estrutura de poder. Com bastante perspicácia, Maria Isaura observou:

conscientes de seu poder, sabem que foram elas que permitiram a realização da festa e que, através das autoridades e da própria polícia, estão controlando o seu desenrolar. A própria disciplina do desfile seria, neste caso, uma prova suplementar da hegemonia das camadas superiores e da submissão das inferiores. (Pereira de Queiroz, 1992:107)

Em que pese a imensa importância dessa preocupante tendência histórica, seria bom não nos esquecermos de que, quase sempre, ainda se considera vencedora, ou favorita popular dos desfiles, a escola de samba que faça o público se 
levantar e cantar (Cavalcanti, 1994), a agremiação que leve o povo a vibrar e a dançar junto, que impulsione e arrebate a vibração das arquibancadas, que arraste as pessoas na alegria transbordante e que desfaça extaticamente as oposições desfilante/platéia, ver/fazer...

Aqui e alhures, antes de tudo e sempre, o riso, a festa e a orgia são princípios que fazem pulsar a vida e a sociedade. Mesmo reprimidos e manipulados, procuram incansavelmente um modo de se manifestar. 
$\underset{0}{=}$ 


\section{5 \\ Proximidade e Distância}

No princípio, eram fezes, urina, lama... Depois, vieram paetês, lantejoulas, serpentinas e confetes. Finalmente, quase nenhum contato físico. Nessas poucas palavras está contida uma síntese em três episódios esquemáticos das mudanças de sensibilidade que a história do carnaval europeu revela dramaticamente. Essas transformações têm a ver com modos distintos de vivenciar o corpo e de sentir sua inserção no mundo. É necessário enveredar um pouco por este caminho: assim fazendo, poderemos clarificar o contraste entre a sensibilidade contemporânea e a medieval.

Antes de tudo, precisamos ter em mente que o corpo medieval não era absolutamente o corpo-ferramenta que o capitalismo inventaria séculos mais tarde. Não era esse corpo definido pelos músculos, pela força, pela resistência, pela disciplina e pela rentabilidade. Muito ao contrário, era comparativamente preguiçoso, sem grandes preocupações com o tempo ou com o trabalho, mais voltado para as festas e para a espera que para os empreendimentos e investimentos. $\mathrm{O}$ corpo medieval também não era o corpo-propriedade-privada. Não se tinha transformado ainda neste primeiro e mais fundamental 'bem de produção', do qual o burguês, antes de qualquer outra coisa, deveria tornar-se o proprietário exclusivo. $\mathrm{O}$ corpo não representava ainda esta ferramenta essencial e paradigmática de que o capitalista teria que tomar posse para, valendo-se dela, fazer-se proprietário das demais ferramentas e dos corpos-ferramentas alheios. Tal apropriação será ao mesmo tempo garantia e materialização de sua hegemonia no sistema que se instaura. Com mais razão ainda, o medieval não constituía o corpo-consumidor da sociedade industrial avançada, este que abriga o fundamental de nossa sensibilidade contemporânea.

Há, com importância crescente quando declina a força da Idade Média genuína, um corpo das cortes, dos mosteiros, dos castelos. Um corpo cortês, governado pela formalidade, que ficou mais ou menos cristalizado no imaginário da literatura referente aos tempos medievais. Tal corpo está associado em geral à cavalaria, com seus gestos e vestuários estudados, contidos, precavidos, treinados, disciplinados ritual e quase militarmente. Os mínimos detalhes deste corpo estão formalizados: usar a espada, fazer genuflexão, cumprimentar. Este corpo e sua gramática normativa estão fadados, como veremos, a um poderoso futuro na gênese do corpo individual. 
Entretanto, isso a que chamamos corpo individual era quase totalmente ausente na cultura popular medieval. Para a grande maioria das pessoas, o individual se diluía no corpo social, no cósmico e no universal (Bakhtin, 1987). Em seu magnífico $O$ Processo Civilizador, Norbert Elias, ainda que se referindo a este corpo courtois, talvez nos tenha oferecido a fórmula mais simples, feliz e definitiva para expressar a sensibilidade corporal da maioria dos homens da Idade Média: "o que faltava (...) ou no mínimo não havia sido desenvolvido no mesmo grau, era a parede invisível de emoções que parece hoje se erguer entre um corpo humano e outro, repelindo e separando" (1990:82). Em outros termos, nos tempos medievais nada se conhecia desta censura à informação e à comunicação entre os corpos. Tudo era público, ou publicável: o comer, o excretar, o copular, o dormir, o parir, o vestir, o banhar, o morrer...

Na Idade Média, o ambiente de relacionamento corporal era bastante peculiar, fundamentalmente antagônico àquele que os tempos capitalistas viriam a conhecer. Tal se deve a que o corpo medieval constituía algo perfeitamente coerente com as condições culturais - objeto das considerações de algumas páginas anteriores. Isto significa que o contexto corporal, especialmente em segmentos populares, caracterizava-se, nos tempos medievais, por abraços freqüentes, por contatos próximos, por gestos destemidos. Coexistência e troca de secreções, de cheiros, de tatos, de olhares faziam o corpo inteiramente aberto aos sentidos próprios e alheios. O medioevo era tempo de toques corporais na barriga e nas costas, de liberdade verbal, de descontração, de segurar o interlocutor pelo braço e de estar à-vontade nos encontros epidérmicos. Tempo de um corpo expansivo, indisciplinado, transbordante. Promíscuo - se quisermos -, pois sempre misturado com outros corpos e matérias.

O corpo medieval era totalmente diferente daquele que surgirá no ambiente aristocrático-capitalista. Era um corpo de orifícios dotados de liberdade de expressão, de aberturas que falam, que podem usar de sinceridade. Nos corpos medievais, os orifícios não estavam absolutamente condenados ao silêncio semiótico. Era o corpo da boca que cospe, que vomita, que arrota, que exala hálito. Era corpo do ânus que expele gases, do nariz que escorre... Não era um corpo contido pela musculatura. Nada dessa couraça muscular que oprime os orifícios para que não se manifestem em público, para que se retenham, para que se escondam. Nada de uma rigidez que separa o interior corporal do exterior, que desenha os limites do corpo, restringindo-os à sua corporalidade individual.

Como Mikhail Bakhtin (1987:17) destacou,

o cósmico, o social e o corporal estão ligados indissoluvelmente em uma totalidade viva e indivisivel (...) o elemento material e corporal é um princípio profundamente positivo, que nem aparece sob uma forma egoísta, nem separado dos demais aspectos da vida (...) o corpo e a vida corporal adquirem simultaneamente um caráter cósmico e univer- 
sal; não se trata do corpo e da fisiologia no sentido restrito e determinado que têm em nossa época; ainda não estão completamente singularizados nem separados do resto do mundo.

O corpo medieval nada tinha a ver com aquele que pensamos conhecer e que abriga a nossa sensibilidade. Não se tratava do corpo singularizado e individualizado do burguês. Não era um corpo circunscrito em si. Não era um corpo contido. Não era um corpo fechado, pronto, acabado. Não transmitia a idéia de ser completo em si ou por si mesmo. Não era um território rigorosamente delimitado. Não era um corpo visível apenas do exterior e que mostrasse somente uma superfície, uma fachada lisa e quase sem fendas. Ao contrário do nosso, em que quase todos os orifícios estão escrupulosamente vedados, não era, o medieval, um corpo do qual se eliminassem as manifestações de vida íntima (Bakhtin, 1987). Ele tinha a boca escancarada, o apetite glutão de devorar imensas quantidades - o que o opõe à cupidez do individualismo. Tratava-se de um corpo em movimento, que jamais estava inteiramente encerrado, que estava sempre se desfazendo, refazendo e fazendo outro corpo. O corpo medieval estava sempre absorvendo o mundo, ou sendo absorvido por ele.

Também não era um corpo separado de si mesmo. Por conseguinte, o comer, o beber e o defecar não eram apenas acontecimentos orgânicos: tinham dimensão escatológica. Os excrementos não tinham a significação banal, estritamente fisiológica, que lhes atribuímos hoje. Eram, ao contrário, considerados como um elemento essencial à vida do corpo e da terra, um elo essencial da cadeia que unia a vida e a morte. Aquilo que, para nós, são excrescências a banir, era visto como ramificações que prolongavam o corpo e que o reuniam a outros corpos ou ao mundo não-corporal. Ele atravessava e ultrapassava seus próprios limites: excrescências e orifícios eram pontos onde se fundiam o corpo e o mundo (Bakhtin, 1987).

Não estou falando de um corpo desodorizado pelas palavras. A Idade Média foi época em que não apenas não havia uma moralidade específica de controle do corpo, como também não se aplicavam sobre ele os tabus lingüísticos que conhecemos. Por isso é que se davam nomes às partes do corpo sem preocupações, sem rodeios, sem refinamentos, sem eufemismos, sem circunlóquios. Naquela época, a verbalidade relativa ao corporal ainda não havia sofrido a separação puritana e iluminista que inventou, para falar do corpo, uma língua respeitável (de elite) e outra bastarda (popular). O corpo medieval ainda não era objeto de um discurso moralista: era referido por uma fala singela, rica em conteúdos míticos, mas pobre de 'isto-é-certo-isto-é-errado' ou de 'pode-não-pode'. Do corpo se falava também por meio de representações, de gestos e de canções lascivas, sempre se o concebendo com uma espécie de alegre obscenidade, materializada em um simbolismo que nos pareceria grosseiro. Do ponto de vista da nossa sensibilidade, o medieval seria antes de tudo um corpo 'indecente'. 
No corpo medieval valorizavam-se sobretudo as partes baixas: as nádegas, a barriga, os órgãos genitais, as coxas... Na sensibilidade corporal de então, de acordo com Bakhtin, o baixo corporal é que despontava. O belo, o atraente e o importante estavam mais embaixo do que em cima. Não se pretende sugerir com isto que o estético estivesse ausente das partes superiores do corpo - como o rosto, por exemplo. No entanto, a beleza priorizada não estava aí. Nem o mais importante. A ênfase que hoje emprestamos à face intensificou-se apenas depois da emergência do moderno individualismo.

Somente após a Idade Média, as camas começariam a ter a cabeceira mais cuidadosamente trabalhada que a outra extremidade, expressando o maior valor que se passou a dar às partes altas do corpo em detrimento das baixas, valorização que levou também a que se dirigissem as atenções preferentemente para aquilo que desenhasse o perfil individual com mais nitidez: cabelos, face, olhos, lábios, nariz... Até então, valiam sobretudo as protuberâncias do rosto. Mas estas saliências eram ressaltadas como traços que representavam sobretudo o que transbordava, o que saltava, o que ultrapassava o corpo. Tais traços não funcionavam preponderantemente como signos que o identificassem, como marcadores de uma individualidade exclusiva (Bakhtin, 1987).

Naquele contexto, obviamente, não havia razões para pudores ou vergonhas em relação ao baixo corporal - o que deveria ainda vigorar por muito tempo. Ainda em 1777, por exemplo, expressando a permanência desta atitude em meios sociais bastante sofisticados, a correspondência que Mozart recebeu de uma de suas amigas fazia referência à "bunda da fortuna", "à rachadura do traseiro" da mãe do compositor, e lhe recomendava executar de vez em quando um "pequeno dueto de peidos" (Elias, 1994a:103). Ecos dos velhos tempos. Não se necessitava, nos idos medievais, de qualquer timidez em relação ao grotesco das partes inferiores, simplesmente porque esse grotesco não existia nos moldes em que hoje o conhecemos.

Tal apreciação só começou a fazer sentido plenamente a partir do ponto de vista do Iluminismo. Faz sentido também em nossas mentes de hoje, uma vez que, motivados pela inspiração iluminista, passamos a imaginar o homem como um ser racional. Em conseqüência, passamos também a cultuar nele o elevado, a razão, os excelsos valores, as características transcendentais, as idéias, o abstrato, o espiritual, termos que tendem a exprimir simbolicamente a dignificação da cabeça e do rosto, mais que a exaltação da barriga ou do ânus. Para este modo de compreender as coisas, que é o nosso, nada mais grotesco, naturalmente, do que a reverência ao baixo e ao visceral. Claro está, igualmente, que jamais entenderemos o grotesco medieval se não repelirmos a atitude etnocêntrica diante dele.

No contexto simbólico medieval - retomando o tema para melhor compreensão -, é muito difícil que encontre terreno fértil uma noção como a de lixo, tão corrente em nosso cotidiano contemporâneo. Por esta razão tem viabilidade o que 
chamei de 'coexistência de insuportáveis'. A mente medieval, como vimos, negase a reconhecer qualquer oposição entre vida e morte, afirmando a vida, gritando que só há vida: vida nova, vida velha, mas somente vida. Os excrementos são evocação da continuidade. Os mortos são pessoas que dormem: estão vivos e ressurgem, são carnes que se decompõem mas que também se recompõem... Nesse ambiente em que nada se separa de nada, em que tudo se confunde com tudo, nesse clima caracterizado pela atmosfera carnavalesca das barreiras e dos limites sempre ultrapassados, como pensar no que devia ser banido, posto à parte? Como cogitar o descartável, o inútil, aquilo cuja vida se tenha esgotado?

Tratava-se, na verdade, de um outro corpo - como estamos constatando por pistas as mais diversas -, de um corpo em que não existia sensibilidade à idéia que hoje temos de lixo, como algo em relação ao qual se deva tampar o nariz, fechar os olhos, afastar o contato táctil, responder com engulhos e caras feias. A categoria lixo nem sempre existiu na história ocidental. Nesta tradição, é importante que o ressaltemos, nem sempre se atribuíram os mesmos valores, ou os mesmos significados, aos resíduos que toda sociedade necessariamente gera. Quase todas as sobras, que causam nojo e temor aos nossos corpos de hoje, causavam riso, familiaridade, intimidade, à sensibilidade de nossos antepassados. Não se pode nem mesmo excluir a hipótese de que a convivência com o que hoje nos suscita asco e aversão propiciasse prazer a nossos ancestrais.

O corpo medieval nos oferece um referencial com base no qual podemos entender, por contraste, sensibilidades tão radicalmente distintas aos cheiros, às visões, aos contatos, ao prazer e ao desprazer. A relevância do que chamamos de lixo tem um ponto de nascimento histórico, representando uma referência importante, uma espécie de guinada na história das mentalidades e das sensibilidades momento a partir do qual ela cresceu incessantemente, se agigantou, até atingir as dimensões da angústia em que nos enredamos atualmente (Rodrigues, 1992, 1995).

O lixo, insistamos, é antes de tudo uma questão de cultura: existe fundamentalmente como realidade simbólica. Em geral não é muito fácil compreender que assim seja, porque, além de estarmos acostumados a pensar que se trata de uma realidade objetiva e material, os estudos que o tomaram como objeto quase sempre o fizeram como se fosse um problema eminentemente técnico, muito mais do que histórico ou sociológico. Apesar dessa reificação e dessa naturalização, é preciso não sermos ingênuos e levarmos em consideração que, como tudo, o significado do lixo tem uma história - do mesmo modo como o próprio lixo, como coisa, objeto material, tem uma história, que é função das relações diferenciadas que os homens mantêm com a natureza.

De tal modo tornamos absoluta a noção de lixo, que abordá-lo como uma questão simbólica representa quase a exigência de se fazer uma espécie de psicanálise de nossa relação com ele. Significa algo como um auto-exame, mediante o qual tentamos entender o que o lixo significa, além de si mesmo, para nós, como 
membros de uma determinada cultura, em um momento dado de sua história. Esta psicanálise dos resíduos corresponde fundamentalmente a uma relativização. Por meio dela, tornam-se conscientes dimensões conotativas do lixo que sempre, ou quase, pareceram-nos naturais e auto-evidentes.

Pretendo sugerir que, no fundo, muito mais importante do que entender o lixo em si, como objeto, é compreender as mentalidades e as sensibilidades que puderam 'inventar' algo como lixo: atribuindo, etiquetando, acusando, localizando alguma coisa como inútil, asquerosa, perigosa; e passando a exigir, por vias de conseqüência, atitudes especiais de proteção. Como resultado dessa psicanálise, talvez consigamos evitar projetar sobre outras populações e sensibilidades, passadas ou contemporâneas, das nossas ou de outras sociedades, os nossos sistemas de pensamentos, sentimentos e atitudes. Talvez consigamos evitar que tratemos nossas atitudes relativas ao lixo como se fossem verdades absolutas.

No fundamental, nossos posicionamentos com respeito ao lixo derivam de nossas posturas diante do corpo e da morte. Nada há de arbitrário nessa aproximação metafórica, uma vez que não existe disjunção simbólica entre as questões do lixo, do corpo e da morte. Constata-se mesmo uma similaridade estrutural razoavelmente importante entre elas. Basta lembrar, em primeiro lugar, que o lixo se constitui de dejetos, de coisas consideradas inúteis, desprezadas. Em relação a ele temos as mesmas atitudes normalmente assumidas, em nossa cultura, quanto às partes do corpo tidas como 'excreções' (urina, fezes, sêmen, sangue menstrual)...

Excreções são quase tudo o que o corpo produz mas não aproveita. São o que sobra. São resto. Excreções são, para nós, uma espécie de lixo corporal. O lixo tem algo desses quase-cadáveres que são as secreções corporais: assim como estas são coisas que o corpo produz sem reter, são corpo e ao mesmo tempo não o são, porque dele saíram e se destacaram, o lixo é algo que a cultura produz mas não retém. É quase como um dejeto cultural, uma excrescência do social, quase como um defecar por meio do qual a cultura devolve à natureza aquilo que dela retira - também para que seja devorado por ratos, urubus, cães, insetos, porcos, vermes...

Há ainda um paralelismo estrutural entre lixo e cadáver. Ambos são coisas semiidentificáveis: entre nós é necessário fazê-las urgentemente deixar de serem semi-identificáveis, retirando delas tão rapidamente quanto possível qualquer identidade. Lixo e cadáver são formados de partes destacadas de algo que já foi. São pedaços em decomposição, algo morto em que há alguma coisa de vida. São restos do que foi útil, recordações do que já não é. Em grande medida, lixo e cadáver vão deixando de ser tabu, algo perigoso e ameaçador, na proporção em que perdem suas identidades já parciais: quando viram cinzas, quando voltam a ser terra, quando são queimados e se transformam em fumaça, quando são reciclados e adquirem vidas novas... 
Cadáveres são essencialmente misturas: de vida e morte, de presença e ausência, de proximidade e distância, de semelhança e diferença. O lixo também é, em geral, uma mistura: de restos da casa que estão na rua, de resíduos da rua que estão na casa, de fragmentos íntimos que vieram a público, de partes de todos que já não mais o são, de interioridades que foram exteriorizadas, de algo que deveria estar longe mas está perto. Procura-se transformar ambos tão rapidamente quanto possível, fazendo desaparecer as misturas que contêm.

Até mesmo as maneiras utilizadas para tratar o lixo guardam um certo paralelismo com as que, em nossa cultura, se aplicam ao cadáver. Existem na sociedade contemporânea algumas técnicas mais ou menos padronizadas de se lidar com os restos. Uma delas é guardá-los em porões ou depósitos, para utilização ulterior ou para decisão posterior sobre seu destino final. Outra técnica é levar para um museu. A terceira é jogar no lixo. Estas três maneiras comportam em si, latentemente, o conjunto de modos - espalhados pelos continentes - de lidar com cadáveres e de organizar práticas funerárias (Thomas, 1976; Rodrigues, 1983).

Guardar em porões ou depósitos é um ato muito parecido com o que se faz, em vários lugares (e também entre nós), com os velhos e moribundos: hospitais, asilos, casas de morrer. Colocar em museu lembra a mumificação, o empalhamento e suas variantes: procedimentos destinados a fazer que o objeto perdure e sobreviva à sua vida original. Jogar no lixo, finalmente, segundo as várias técnicas de lidar com os restos, pode corresponder, isolada ou combinadamente, aos demais procedimentos funerários de base.

Assim, no método mais simples, o lixão, jogar no lixo assemelha-se à exposição, técnica funerária em que o cadáver é entregue ao clima e aos processos orgânicos. Dependendo das circunstâncias, jogar no lixo pode também lembrar a inumação, procedimento que consiste em remeter o cadáver às entranhas da terra - o que, aliás, se está tentando fazer com o chamado lixo atômico. Jogar no lixo evoca também a cremação, quando os resíduos são incinerados para se transformarem em pó e gás. Há mesmo tecnologias de lidar com as sobras que se assemelham à moderna criogenização, ou congelamento, método funerário fundado na esperança de que os cadáveres possam vir a ser reciclados para retornar à vida, tal como é possível fazer com vidros, papéis, plásticos e metais.

Nos tempos em que vivemos, a questão da morte tem a ver, cada vez mais, com a do lixo. Tal fato não se dá, nem tanto, porque vivamos na cultura do útil e do funcional e o lixo seja aquilo que já morreu, que já não serve mais, que já não tem mais vida funcional (e isto, mesmo que se tente nele incutir uma espécie de sobrevida, por meio desta preocupação tão sintonizada com a mentalidade contemporânea que é a reciclagem). Lixo e morte se associam simbolicamente em nossas sensibilidades hodiernas simplesmente - e aí está a razão crucial da angústia em torno destes dois problemas - porque, na cultura industrial, morrer é mais ou menos como ir para o lixo. Semelhante afinidade estrutural, entre o lixo e a morte, impõe- 
se entre nós em ambas as direções: seja porque aquilo que vai para o lixo é o que está morto, seja porque morrer, em nossa cultura atual, é um pouco como ir parar no lixo. Nessa metáfora não há sentido literal nem figurado, significado primeiro ou derivado: por um lado ou por outro, sempre encontraremos a perda da funcionalidade e o rápido esquecimento de mortos e lixo.

Há, ainda, associando os restos e a morte, uma questão dramaticamente angustiante na sociedade de hoje. A civilização industrial é por excelência a civilização dos dejetos que ela detesta e, por conseguinte, da angústia do lixo. Mesmo que não queiramos admitir e que procuremos nos iludir com falsos argumentos ecológicos, sabemos todos, implicitamente, que quanto mais sociedade industrial, mais lixo, necessariamente, mais e mais subprodutos. Pensando no sistema como um todo, quanto mais se recicla, mais resíduos da reciclagem e mais lixo. As periferias das cidades estão lotadas de montanhas de lixo, reciclado ou não. Sem fazer ficção científica, alguns já começam a delirar sobre o dia em que essas montanhas de lixo serão do tamanho do planeta, produzindo uma imensa e definitiva asfixia. Claro que este dia não vai chegar! Isto corresponde ao soar de um alarme sobre os limites da sociedade industrial e de consumo, além de implicar um alerta sobre a iminência da morte - exatamente em uma cultura que tem a morte como uma de suas dimensões mais detestadas.

Não desprezemos, contudo, o fato de que, para uma cultura que pretende acumular riquezas, a inclusão daquilo que o lixo representa é a de uma insuportável imagem. O lixo é um absurdo e esdrúxulo estoque de restos e de decaídos, um imenso amontoado de inutilidades, um aberrante descompasso entre essência e existência. Tudo isso exatamente em frente aos olhos de uma sociedade que cultua o pragmatismo, que venera a exatidão, a funcionalidade e o esplendor. Depois de inventá-lo como um 'outro' indesejável de si, a cultura utilitarista e pragmática do Ocidente só pode querer dizimar o lixo, como 'etnocidamente' tem procedido com relação a todos os outros que tem encontrado pelos caminhos de seu progresso e de sua expansão.

Nos limites do imaginário, este outro, como acontece no caso dos restos, é visto como um invasor a ser banido ou exterminado, não como algo endogenamente produzido. Há, por conseguinte - e por mais que se respeitem as boas intenções dos ecologistas de superfície -, raízes culturais profundas e nada ingênuas nos sonhos contemporâneos de acabar com o lixo e de produzir um mundo ecologicamente higienizado. Há poucos anjos participando deste debate. A atitude etnocida não está ausente nem mesmo de uma parcela ponderável dos que querem alertar contra as ameaças que o modo de vida industrial oferece à saúde ambiental. A anuência destrutiva está presente até mesmo naqueles que, invadidos pela ética do 'domínio da natureza' mais profundamente do que gostariam de imaginar, costumam limitar-se a propor soluções meramente técnicas, administrativas e gerenciais. Intensificam, por este caminho, a existência do modelo de vida que é responsável pela crítica questão ambiental. 
A sociedade contemporânea tem entre suas características mais evidentes o assentamento de poderes que procuram legitimar-se pela promessa de uma certa garantia contra a morte e a miséria, nas suas mais diversificadas formas. Tal promessa se tenta realizar, principalmente, pelo controle e pelo afastamento da decomposição e do apodrecimento, colocados tão longe quanto possível dos olhos dos cidadãos. Isso implica, por exemplo, o banimento, o mascaramento ou a supressão da doença e da velhice. Em termos mais sintéticos, o cumprimento da promessa requer aniquilamento do que esta sociedade considera dejetos, pois estes carregam simbolicamente ameaças de degenerescência e morte. Ocorre, entretanto, que os controles sobre a morte e o lixo são mais imaginários do que reais. Resulta daí uma constante tensão entre desejo e efetividade - tensão freqüentemente aliviada pela multiplicação dos discursos ecológicos, pela exacerbação do imaginário e pela mise-en-scène algo dramática da 'despoluição'.

A tudo isso se adiciona uma característica agravante. O lixo industrial, contrastando gritantemente com o medieval que nos causa tanta repugnância, é cada vez menos constituído de resíduos orgânicos, desse tipo de restos que nos causam especial horror pelo que evocam de morte e de tanatomorfose. Esse lixo orgânico, todavia, degrada-se pela própria ação da natureza e nele é possível divisar alguma dimensão de regeneração e vida. Tal lixo, na verdade, é a própria vida retomando seu ponto de partida, conforme concebiam os homens do medievo. Ao contrário, o novo lixo, de que temos asco apenas quando misturados a restos orgânicos, é algo que os homens não conseguiram digerir e que lançam à natureza, para que esta também não o consiga. Daí a razão simbólica da importância, crescente em nossa cultura, de se fazer a seleção do lixo, separando (equivocadamente) um lixo que ameaça simbolicamente de outro que parece ser politicamente neutro.

Os novos restos de nossos tempos são, entretanto, um lixo que é vida sem morte, que não retorna às origens, que se acumula incessantemente sem se destruir, avançando contra todas as formas de vida. Trata-se agora de um lixo ecocida e genocida, a gerar resíduos cada vez mais nefastos, por conta de sua elevadíssima e crescente concentração. No entanto, com freqüência nos iludimos quanto à periculosidade dos dejetos. Por isso, é necessário ressaltar que somos, equivocadamente, muitíssimo mais sensíveis àquele lixo que de fato é menos destruidor. Tal ilusão é efeito paradoxal do advento da nossa moderna sensibilidade corporal, caracterizada por ser muito mais individualista e, em grande medida, desdenhadora do coletivo.

Por trás do paradoxo, contudo, uma voz gradualmente se faz sentir, cada dia mais forte, despertando em nós uma espécie de angústia-de-fim-do-mundo em torno da questão do lixo. Esta angústia está sempre presente, como um espectro de morte, no horizonte dos progressos de nossa capacidade industrial de gerar lixo e de o fazer circular. Não podemos esquecer que os debates recentes sobre a questão do lixo têm como pano de fundo, embora não o explicitem, exatamente o contexto deste paradoxo ecológico. 
Tais características fazem do lixo, assim como do cadáver e das secreções corporais, aquilo que em nossa cultura, por excelência, queremos ou precisamos distanciar. Acontece, todavia, que uma sociedade é ao mesmo tempo o seu interior e seu exterior. Em outras palavras, toda sociedade é um 'dentro', regido pelas suas normas, mas simultaneamente também um 'fora', que não o é senão parcial e ilusoriamente, uma vez que não passa do correlativo binário daquele dentro e das normas que o definem como fora. Embora às margens, este fora nunca é, por conseguinte, inteiramente marginalizado, nunca é totalmente exterior. Em uma lógica de significação, o excluído pode perfeitamente estar no âmago, exatamente para cumprir uma função significacional no interior. Esta função é quase sempre a de testemunhar para a sociedade aquilo que ela não quer ser.

Ora, se este 'fora' é de fato um 'dentro', afastar algo, como no caso do lixo, é necessariamente aproximá-lo de alguém. Está presente aí um movimento de poder estruturalmente inevitável. Banir o lixo corresponde ao gesto de aproximálo dos lixeiros, dos caminhoneiros, dos moradores das favelas, dos pobres, dos países do Terceiro Mundo... Este longe, para onde se pretende enviar o lixo, será sempre um perto. Esta expulsão será invariavelmente inclusão. Expulsar o lixo do centro, independentemente das boas intenções, corresponde inexoravelmente a aproximá-lo da 'periferia'. Nada há nisso de neutralidade técnica ou política.

O sentido de tudo isso é muito simples: quanto mais próximo do centro de poder, mais distante da poluição; quanto mais periférico em relação ao centro de poder, tanto mais íntimo da sujeira ou do lixo. Nunca há definição de 'impuro' sem a existência de um poder que se queira próximo ao puro e que defina uma hierarquia com base em sua posição. A sociedade asseptizada é automaticamente uma sociedade hierarquizada. A luta contra a poluição (seja pecado, sujeira, moralidade, raça ou toxicidade) está sempre associada ao estabelecimento de um poder (religioso, econômico, administrativo), ao advento ou chegada de certas figuras poderosas (xamãs, líderes, chefes de Estados, ou mesmo visitas) e ao crescimento de uma certa ordem (Latouche, 1978). Aí está, sob o nosso culto à limpeza e à separação dos restos, uma dimensão política que com freqüência desdenhamos.

Nosso ponto de vista individualista quase sempre nos impede de ver a sociedade em sua totalidade. Por isso, em geral não percebemos que a perda do valor de uso de algo, que o institui como dejeto, não abole absolutamente o seu valor de troca. Não conseguimos perceber que aquilo que cada indivíduo em particular rejeita e joga na lixeira apenas inicia, neste ponto, uma nova fase de seu itinerário de circulação social, passando a ser valor de uso para outros. Quando apreciamos a sociedade em seu conjunto, constatamos facilmente que o lixo de uma camada pode perfeitamente representar o luxo de outra, e reciprocamente, pois que, a rigor, o valor de troca é que inventa o valor de uso. Adotando uma perspectiva holística e sistêmica para considerar a sociedade, conseguimos entender que não existe lixo absoluto e que suas dimensões materiais estão sobrecarregadas de relações sociais e simbólicas. 
Se aplicarmos esta lógica às aglomerações urbanas, não será nada difícil adivinhar o que forçosamente acontecerá com pobres, velhos, prostitutas, estrangeiros, favelados e outros 'periféricos', por mais objetivamente higienizadas ou urbanizadas que venham a ser suas condições de vida (água em abundância, coleta freqüente do lixo, equipamentos de higiene corporal etc.): de um ponto de vista global, simbólico e relativo, a hierarquia social sempre estabelecerá gradientes para classificar, ou inventará outros critérios de discriminação de pureza e poluição.

Compreensivelmente, a pedra angular dessa hierarquização será constranger uma parte da população a consumir o que é refugo de outra. O que chamamos de dejetos na verdade são valores. Aqueles que estão no alto da hierarquia valorizam-se, sobretudo, pelo que rejeitam possuir, tocar ou consumir. Em uma sociedade de consumo plenamente realizada, as camadas se diferenciam hierarquicamente menos pelo que gastam e consomem do que pelos restos que espalham ou que transferem umas para as outras.

O lixo se transforma, deste modo, em instrumento semiótico de diferenciação de classes sociais. Isto traz no mínimo duas conseqüências ecológicas, intimamente associadas: por um lado, o encurtamento da vida dos objetos, pois estes devem, em todos os níveis da sociedade, ser descartados tão rápido quanto possível, a fim de expressar a superioridade daqueles que os desprezam; por outro lado, como óbvia e necessária decorrência deste processo de distinção sociológica, encontramos a exponencial multiplicação do lixo.

Jamais devemos esquecer que as regras de poluição estão estreitamente ligadas à marcação de distâncias sociais entre pessoas, grupos, estratos, objetos e idéias. Toda sujeira é relativa e gradativa. Obviamente, existem técnicas rituais que limitam a ação de sua destrutibilidade, segundo os vários contextos. $\mathrm{Na}$ Índia, por exemplo, o estrume de vaca é considerado sujo para a vaca, que deve ser cuidadosamente separada e protegida de seus excrementos; todavia, estas dejeções são tidas por algo limpo até mesmo pelos brâmanes, que podem se purificar passando-as pelo corpo.

Podemos perceber a gradatividade e a relatividade do conceito de sujeira mesmo em pequeníssimos atos que explicitamente são praticados para fins outros que a marcação de distâncias sociais. Gestos sutis como, por exemplo, o do dono da casa limpar com as palmas das próprias mãos a cadeira em que nos convida a sentar, ou o de lavar diante de alguém um copo ou uma xícara que acabou de retirar já limpos de um armário, dotando-os, por assim dizer, de limpeza adicional - gestos comuns quando visitamos casas que os brasileiros costumam chamar de humildes e que são, além de simples demonstração de boas maneiras, uma mensagem ritual implícita sobre as posições sociais respectivas. Igualdade e familiaridade dispensariam totalmente semelhantes procedimentos.

Pessoas socialmente em plano idêntico estão, em geral, reciprocamente dispensadas ou têm bastante atenuadas as obrigações relativas a tais regras de separação, de pureza e de poluição. Podem utilizar os mesmos utensílios de cozi- 
nha, por exemplo, como acontece entre indivíduos da mesma família. Não é isso, aliás, o que ocorre também com pentes, escovas de cabelo, toalhas, sabonetes etc., que só podem ser compartilhados por pessoas de nível semelhante? Não acontece de alguns fazerem uso comum das roupas de cama, roupas de baixo e até escovas de dentes? Contudo, lembro-me perfeitamente de que as casas da classe média, na minha infância, possuíam talheres especiais (garfos, colheres, pratos, copos), em geral feitos de alumínio, destinados ao uso exclusivo dos mendigos que batessem à porta, coisa que acontecia, aliás, com razoável freqüência.

Exprime relação de hierarquia fazer aquilo que para o outro é sujo (Dumont, 1966; Douglas, 1970; Rodrigues, 1979). Não é justamente esta a situação dos escravos quanto a seus senhores, dos pobres com relação aos ricos, das mulheres com respeito aos homens, das empregadas domésticas para com suas patroas? Não é isto também o que se verifica em muitos países muçulmanos, nos quais só deve usar a mão esquerda para tocar coisas impuras, mas onde, com freqüência, as mulheres se vêem constrangidas, na prática, a fazer uso de ambas as mãos, para realizar suas tarefas cotidianas?

Talvez se possa mesmo dizer que é precisamente no ato de se fazer aquilo que para o outro é impuro que a reafirmação das hierarquias simbolicamente se expressa de modo mais insofismável e poderoso. Boa ilustração é o sistema indiano de estratificação, em que os trabalhos de limpeza se dividem entre as castas, sendo as baixas as que lidam com o lixo, recaindo rigorosamente para a mais baixa de todas a tarefa de limpar as latrinas. Quem contrata uma faxineira diarista e uma empregada doméstica sabe perfeitamente que a função que a primeira mais detesta, evitando-a ou rejeitando-a, freqüentemente de maneira enfática, é a de limpar o banheiro e, especialmente, a latrina da segunda. O medo de poluição funciona apenas em uma direção: quem está no alto, em princípio, não polui quem está embaixo; os inferiores, entretanto, conspurcam seus superiores. Por esta razão, superiores e inferiores procuram manter-se meticulosamente afastados.

Compreende-se perfeitamente, assim, que os discursos sobre poluição palavra inexistente, por sinal, nos tempos medievais (Gimpbel, 1976) - estejam quase sempre marcados por espírito de acusação. Acusar de impureza significa reivindicar a própria superioridade. Uma decorrência deste fato é que, em lugar de denunciar social e politicamente o sentido das regras de pureza, em vez de questionar pela raiz a sociedade de consumo - responsabilizando radicalmente os industriais poluidores e os próprios consumidores, que não deixam absolutamente de ter sua parte de responsabilidade -, os discursos de sanitaristas, pedagogos, publicitários, políticos etc. direcionam seus canhões injusta e exponencialmente contra os 'marginais'. Em outras palavras, apontam para os inferiores.

Estes últimos se transformam, por conseguinte, em bodes expiatórios e passam a ser culpados dos perigos que a impurificação comporta. Por este percurso irônico, "os dejetos da sociedade se transformam em responsáveis pela 
sociedade dos dejetos" (Latouche, 1978:97). Agora são eles que devem ser reprimidos, esclarecidos, educados... São eles que devem ser policiados. Seus hábitos de limpeza/sujeira são o que justifica a demanda por mais e mais 'ordem' e acabam requerendo, incessantemente, a presença cada vez mais ativa do Estado. Por efeito desta ironia, acaba-se substituindo a polícia, historicamente feita pelos habitantes, por um policiamento exercido sobre os moradores (Guillaume, 1978). Sob as boas intenções, aparentemente inquestionáveis, quanta discriminação!

Aqui - como um pequeno laboratório para refletir sobre as questões mais amplas que estamos perseguindo neste livro - talvez seja possível ousar algumas indagações, no que concerne ao problema do lixo nas camadas de baixa renda, nas populações menos favorecidas, 'marginais', 'carentes'... Até que ponto persiste nelas, nas culturas populares, como as últimas em geral a serem totalmente conquistadas pela visão de mundo capitalista, algo daquela entrosagem medieval com o universo que, como sabemos, ainda não foi extinta por inteiro, mesmo nos países altamente industrializados da Europa? Até que ponto, em vez de negatividades, como ignorância, irresponsabilidade, carência educacional e assim por diante, existiria nessas camadas uma vontade positiva e prazerosa de convivência com o que, para a cultura capitalista, é dejeto detestável? Até que ponto poderíamos reconhecer nelas uma resistência renitente contra a conversão que as cruzadas da modernidade lhes querem impor? Até que ponto estaria presente um 'não' contra a cultura capitalista e industrial que lhes querem incutir, por meio da educação, das campanhas de 'esclarecimento' público, dos meios de comunicação de massa e dos programas universitários ou governamentais de intervenção nas comunidades?

Até que ponto tratar-se-ia, nessas populações, de um corpo ainda diferente, de uma sensibilidade ainda distinta e diversa, que ainda convivem intensamente e sem grande infortúnio com aquilo que detestamos? Afinal, esta 'convivência com o insuportável', em populações medievais ou contemporâneas, não é algo parecido com o que acontece com as crianças, ao experimentarem prazer em brincar com lama, lixo ou fezes, até serem ensinadas - pelas caras feias, pelos tapas, pelos castigos que lhes infligem os adultos - a detestar o que lhes fora agradável?

Este questionamento não significa automaticamente, sem embargo, que devamos sustentar a possibilidade de que as regras de poluição deixem de se aplicar nesses meios sociais. Elas existem aí também, embora dirigindo-se contra outras pessoas, com ênfase em outros domínios da experiência, e atualizando-se em outras circunstâncias. Elas se fazem presentes, produzindo hierarquias entre subalternos, discriminando, estabelecendo limites, acusando. Um estudo ainda inédito sobre o lixo e sua significação entre os moradores da Rocinha, favela do Rio de Janeiro, sugeriu que aí também prevalece uma lógica de acusação de impureza, que resulta em que o impuro seja sempre o outro e que a 'periferia' também tenha as suas periferias. 
Ainda que tudo isso seja muito polêmico, gostaria de chamar a atenção para o fato de que, em vez de atribuir a essas populações um 'menos', seria interessante relativizar nossas próprias idéias de poluição, nossas hierarquias e nossos valores. Talvez seja esta uma das melhores contribuições da antropologia para o estudo de nossas sensibilidades. 


\section{6 \\ Cidade e Campo}

Como todos os seres vivos, os homens devem viabilizar materialmente a existência. Que o coração pulse, que o sangue circule, que os pulmões aspirem, tudo isso é acontecimento material que deve ser materialmente possibilitado. Este é um primeiro ponto, crucial para qualquer reflexão sobre a vida, inclusive sobre a vida humana. Neste plano, entretanto, nada é característica exclusiva dos seres humanos e ninguém vai muito longe no pensamento antropológico se permitir que a reflexão se detenha aí: não é isso que faz da vida uma vida humana. Sem desprezar, evidentemente, esses aspectos que estão na base de qualquer existência orgânica, é preciso considerar que a vida humana se realiza apenas depois de vencidos esses desafios de fundamento, a que se limita a existência das plantas e da maioria dos animais. O existir humano, no que tem de especificamente humano, transcende em muito os processos puramente orgânicos: faz-se pelas danças, pelos mitos, pelos rituais, pela comensalidade, pelas trocas simbólicas, pelas relações de parentesco, pela arte, pela religião... Faz-se por tudo aquilo, enfim, que só pode ser encontrado dentro do universo humano.

É óbvio - e este é um segundo plano - que tais dimensões que transcendem a dimensão meramente orgânica também devem ser materialmente possibilitadas. A vida material humana inclui necessariamente tudo o que não é diretamente material. Deve responder pelas especulações, pelos delírios, pelas festas, pelas oferendas e sacrifícios, pelos transbordamentos, pelas alianças, pelas guerras... Nenhuma sociedade humana se limita a atender a meras necessidades. Muitíssimo ao contrário, característica radical dos homens é serem animais capazes de voluntariamente abrir mão de suas existências biológicas individuais em nome da sobrevivência coletiva, em nome das concepções simbólicas que os reúnem e que atribuem determinado sentido, já bem longe do puramente biológico, a suas existências. Esse simbólico abstrato em torno do qual os homens se unem é, certamente, o que de mais concreto há.

Como todos os seres vivos, os homens convivem. Não apenas como organismos individuais que convivem em grupos, mas como grupos que se relacionam em sociedades e sociedades que coexistem entre si. Essas relações sociais 
entre grupos sociais também devem ser materialmente viabilizadas. Não há sociedade humana isolada: espelham-se em busca de suas identidades específicas, aliam-se, afastam-se, opõem-se, comerciam, guerreiam... e nada disso cai pronto do céu: precisa ser materialmente viabilizado. Aqui está um terceiro plano: ele nos convida a retirar o olhar dos limites ditados pela observação de uma sociedade humana específica e a dirigi-lo para a consideração da humanidade tomada em seu conjunto.

Esses três planos estão presentes em todas as vidas humanas, individuais ou coletivas. Ninguém vive apenas como organismo: convive. Ninguém convive apenas como interação: compartilha. Nenhuma vida se faz apenas como contenção: expande-se. Para os homens é tão necessário viabilizar o dar e receber quanto o respirar; tão importante propiciar o consumar quanto o acumular, o dar e festejar como o trabalhar e produzir.

Um certo equilíbrio entre esses planos é fundamental. Sociedades que não viabilizam o primeiro sequer chegam a existir: a vida se extingue em seu fundamento mais rasteiro. Sociedades que não viabilizam o segundo não existem como humanas. Primeiro e segundo planos são mais ou menos automáticos nas sociedades humanas, sobretudo quando vistas em isolamento. Há, contudo, algo de antropologicamente nevrálgico em relação ao terceiro plano, pelo que pode acarretar de conseqüências em relação aos dois primeiros, consoante as três modalidades básicas de ele acontecer. Procurarei apresentar sinteticamente essas modalidades e delas extrair algumas conclusões úteis para o desenvolvimento de nosso raciocínio.

Vamos, primeiramente, supor uma sociedade cujo terceiro plano seja desfavorável. Podemos imaginar uma população saqueada por inimigos que the tolheram a possibilidade de uma vida plena. Em princípio, onde, em que planos, esta sociedade tentará se arrimar? Onde buscará ela a energia que lhe permitirá continuar a existir? Caso tenha que realizar 'cortes' em si mesma, auto-amputações, onde escolherá fazê-lo? A resposta a tais perguntas pareceria muito fácil e óbvia à primeira vista: colocada em tal circunstância, qualquer sociedade optaria por preservar o primeiro plano, aquele que garante a continuidade da vida biológica. E esta resposta fácil talvez seja verdadeira para quase todas as formas de vida.

Para os seres humanos, no entanto, valerá esta resposta óbvia? Quando vemos homens construírem e reconstruírem, exatamente no mesmo sítio, as suas aldeias já repetidamente destruídas por vulcões, terremotos, inundações etc., é na direção da sobrevivência biológica que o nosso raciocínio está convidado a caminhar? Quando vemos sociedades inteiras condenarem à morte por inanição fragmentos ou grandes porções de si, quando vemos homens famintos oferecerem comida aos ancestrais, quando nos lembramos dos jovens pilotos japoneses partindo para suas missões kamikases e entregando ao coletivo as suas vidas orgânicas individuais, é pelo caminho sugerido pelas respostas óbvias e fáceis que nossa inteligência se deixa persuadir? 
Não me parece, de modo algum, ser esta a lição que os antropólogos têm recebido. Não é a sobrevivência orgânica que faz, dos homens, homens. Importam - nesses momentos de crise, em que a vida orgânica individual ou coletiva é posta em questão - exatamente os ancestrais, os altares, os emblemas, os valores... Importa a sobrevivência simbólica. A resposta fácil e óbvia não vale para os seres humanos, por mais que os economistas e suas filosofias afinadas com o espírito do capitalismo disso nos queiram convencer. Em que pese o fato de que, na prática, fora das situações mais extremas, uma espécie de administração sempre tenha lugar - ditando que algo se realize, com dificuldade, em cada um dos dois primeiros níveis -, é justamente no primeiro plano, sacrificando, ceifando vidas, produzindo mártires, que os homens, ao contrário, preferirão realizar amputações: a consumação de vidas individuais e orgânicas no altar da vida coletiva e simbólica.

Façamos um segundo exercício de ficção sociológica. Imaginemos no laboratório de nossas mentes a situação inversa, de uma sociedade extremamente favorecida em seu terceiro plano. Que lhe acontecerá? Ao menos em tese, estará dispensada de viabilizar o seu primeiro plano, uma vez que isto já será propiciado em ponderável medida pelas sociedades que explora. Poderá, conseqüentemente, direcionar a maior parte de seus esforços para a geração do seu segundo plano e para o contínuo fortalecimento do terceiro. Poderá, até mesmo, 'exportar' o seu segundo plano para sociedades que, na primeira situação, encontram-se em dificuldades de gerá-lo por si mesmas.

Exploradas, as sociedades que se vêem na primeira situação, além de serem obrigadas a decidir sobre auto-amputações no primeiro plano, também terminam sendo um pouco 'importadoras' da vida cerimonial e simbólica que sobra, quase como resto, das sociedades e grupos situados na segunda circunstância - e isto corresponde a uma auto-amputação também no segundo plano, por sacrificar agora não mais vidas biológicas pulsantes, mas identidades sociais, vidas simbólicas. Por excelência, esta última situação, favorável quanto ao terceiro plano, é a da riqueza e do dispêndio - mas também da acumulação e da banalização.

Uma terceira simulação pôr-nos-ia diante de sociedades que apresentassem equilíbrio entre os três planos. Nelas não encontraríamos as questões dramáticas de sobrevivência biológica que afetam as sociedades que se encontram na primeira situação. Não veríamos as dificuldades, daí decorrentes, de se entregarem à vida cerimonial e de construírem ou preservarem a auto-identidade que define o 'nós'. Também não encontraríamos o oposto disso, um segundo plano tão farto e artificial, tão facilitado e corrente, tão distante da escala do humano, que se banalizaria ou seria magnificado pelo excesso. Encontraríamos aqui, nas sociedades em equilíbrio quanto ao terceiro plano, uma espécie de harmonia entre os outros dois: intensa atividade e ligação em relação a tudo aquilo que faz a vida humana individual pulsar como animalidade, ao mesmo tempo em que vibra no cerimonial e na plena intensidade simbólica. Nem acima nem abaixo da escala do humano, nesta vida não há lugar para o banal ou desprezível. 
É muito importante termos em mente que estamos tratando com um modelo teórico de relações sociais e de relações entre relações sociais. Com essa advertência, quero chamar a atenção para o fato de que uma sociedade ou um grupo que esteja em situação desfavorável, no terceiro plano, quanto a uma outra sociedade ' $x$ ' pode perfeitamente estar em situação favorável com respeito a uma sociedade ou grupo ' $y$ '. Assim, um país pode estar em situação desfavorável em suas relações com um segundo, mas pode modificar essa circunstância no que tange a um terceiro. $\mathrm{O}$ mesmo se aplica às cidades e seus bairros, às cidades entre si, às classes sociais, às relações cidade-campo, aldeia-campo...

Ressalvando o elevado nível de abstração em que se situam essas idéias, gostaria de observar que constitui problema sempre delicado o equilíbrio nas relações entre as sociedades humanas, no sentido de evitar as situações extremas. Assim como não pode haver predadores a um ponto tão extremo que cheguem a eliminar totalmente as presas de que se nutrem, as sociedades não podem sair favorecidas das relações intersocietárias sem que se envenenem a si próprias com as toxinas de que seriam supostamente beneficiárias. Não será esta, talvez, a situação das sociedades industriais que, depois de espalharem pelo planeta os seus dejetos e suas misérias, começam a senti-los novamente perto ou dentro de si?

A existência urbana configura uma situação antropológica bastante característica, no âmbito da problemática que acabei de invocar. Não é possível a emergência de uma cidade sem que a acompanhe algum tipo de assimetria social, interna e externamente. Toda cidade é mais ou menos como um parasita e, nos casos mais extremos, como um tumor: em princípio, incapaz de gerar sua própria existência e continuidade, uma vez que não é da essência das cidades gerar o primeiro plano da vida de seus membros. Ao contrário, a cidade rouba alhures este primeiro plano, procedendo mais ou menos como uma sanguessuga em relação ao que a circunda - ela suga para se abastecer, ela explora, escraviza; depois, expele resíduos, toxinas; polui. Tudo isso só é viável mediante certas circunstâncias. Tudo isso só se realiza se preexistirem e prevalecerem determinadas estruturas de poder.

O fenômeno urbano sempre teve alguma coisa de excepcional. Se olharmos para o conjunto da história da humanidade - tentando apreendê-la através de uma espécie de grande-angular -, veremos a cidade aparecer, em geral, como algo simultaneamente centrípeto e centrífugo, atraindo e liberando populações que nela se encontram de modo quase episódico e transitório, como se fosse um centro cerimonial para onde os homens se dirigissem em busca de maiores e mais intensos prazeres coletivos, de prazeres que pudessem ser momentaneamente propiciados por uma vida social mais efervescente, pelos contatos humanos mais numerosos, pelas festas e pela liberação do imaginário, pelo consumo e pela consumação de alimentos e produções estéticas... 
De certo modo, a cidade existe, antropologicamente, como o lugar por excelência do segundo e do terceiro planos. Existe como espaço simbólico e imaginário, antes de existir como realização arquitetônica em pedras ou tijolos. Antes de se instituir como lugar de residência permanente para alguns - o que será fenômeno tardio e raro na história da humanidade -, a cidade é ocasião social de encontro e reunião, ponto de confluência periódica, atrativo de peregrinação para homenagear as divindades mais numerosas. O urbano tem vocação para folhas, flores e frutos. Quase nada tem de raiz. Por isso, compreende-se que, no macrotempo da história humana, as cidades não costumem durar, que sejam eminentemente perecíveis, que tenham vida breve, embora intensa. Por isso entendese que a decrepitude que as atinge seja um fenômeno antropologicamente tão importante quanto seu florescimento (Duvignaud, 1977a).

É muito sintomático que a cidade esteja sempre associada ao cemitério e que a cidade dos mortos seja historicamente anterior à dos vivos. Sintomático porque dispor de habitação estável e distante das fontes de vida sinaliza o poder e privilégio daqueles que têm suas vidas propiciadas por outros. A cidade supõe disponibilidade de víveres, excedentes que alguém deve providenciar. Evidentemente, quanto maiores as dimensões de uma cidade, mais intensas deverão ser as pressões e coerções que será forçada a exercer sobre o seu entorno: por isso, a cidade é fundamentalmente lugar de confluência de poderes religiosos, políticos e econômicos; por isso é lugar de concentração de uma burocracia que reúne em si funções que um dia estiveram disseminadas; por isso é território de instituições especializadas (governo, templo, tribunal, presídio, fisco, escola, arquivo, hospital), aonde se torna cada vez mais obrigatório comparecer; por isso é sede de organizações militares e agente de arregimentação. Castelos, fortalezas, muros, aparatos de guerra não se destinam apenas a proteger os citadinos de inimigos que vêm de longe. A potência que as cidades materializam na dureza das pedras é mensagem de segurança. Mas também de ameaça, para os que estão próximos. Mensagem cujos destinatários são, sobretudo, camponeses e demais subalternos.

Por essas características do urbano, podemos perfeitamente compreender que a relação entre a cidade e o campo que a viabiliza sempre foi potencialmente tensa. A cidade foi historicamente possível porque a interpenetração entre cidade e campo sempre foi maior que a disjunção. Fundamentalmente, a interpenetração e a proximidade campo-cidade foi o que permitiu que a última existisse, tanto no plano material como no das mentalidades. Mesmo simples agrupamentos de pequena durabilidade, com populações eminentemente efêmeras, como santuários, como túmulos freqüentados por pequenas multidões, como lugares de encontros ocasionais para trocas e comércio, como fontes de água às quais as pessoas acorressem, mesmo aldeias muito pequenas não poderiam dispensar uma dependência quase total do campo. 
A cidade que finge desconhecer o campo é um fenômeno moderno, muito próximo do extremo que mencionei anteriormente. Um acontecimento praticamente incogitável durante quase toda a história da humanidade e que começou a aparecer no Ocidente apenas a partir do século XII, quando a aristocracia européia passou a trocar os campos pelos núcleos urbanos. Até então, cerca de quatro quintos da população das cidades medievais eram constituídos por produtores, na maioria ligados ao campo e ao cultivo (Mumford, 1961).

Os próprios palácios dos príncipes romanos e carolíngios, que a história costuma associar à origem dos centros urbanos europeus, raramente se encontravam nas cidades: situavam-se, como regra geral, nos campos, nos domínios de suas dinastias. Os condes a quem a administração romana estava confiada não se instalavam em lugar fixo: percorriam constantemente suas circunscrições para recrutar tropas, amealhar impostos, presidir as assembléias, pois o centro da administração era sua pessoa, não sua residência (Pirenne, 1964). Como todo homem medieval, os poderosos também eram peregrinos potenciais ou simbólicos (Le Goff, 1989).

O urbano da Idade Média era diretamente circundado e invadido pelo campo, visível de qualquer colina, torre ou janela. Poucos produtos utilizados na vida cotidiana das cidades procediam de lugar mais distante do que alguns quilômetros. Eram famílias, vizinhos e passantes que se associavam em casas, ruas, mercados e praças, com plantas, animais e córregos - tudo isso sobre um território no qual viveram também os ancestrais.

A cidade era espaço nada exclusivo de homens: cães, cordeiros, cabras, vacas, cavalos, porcos eram simultaneamente companhias, produtores e eliminadores de resíduos. Com os homens, em ruas e casas, conviviam os ratos, mas obviamente também os gatos; os alimentos, mas também os excrementos. Os muros que com freqüência envolviam a cidade e as portas que a isolavam tinham, em geral, funções mais simbólicas, de marcação de fronteiras, de definição de identidade social, que finalidades propriamente ecológicas. Toda cidade estava dentro do campo e tinha o campo dentro de si, visto que entre as casas havia sempre terrenos cultivados, hortas, jardins, quintais, pomares, pastos, paióis, celeiros, estábulos... Os alimentos eram cultivados dentro das muralhas, assim como nas áreas circundantes.

Esses traços valem unanimemente para as cidades da Idade Média. Não é à-toa, de modo algum, que a cidade medieval é muito mais irregular e sinuosa do que planejada e linear. Há nela uma espécie de improvisação que simplesmente reproduz este princípio de integração do urbano com o ambiente em que se estabelece. No entanto, esta integração, em vez de destruir o contexto físico em que se dá, procura incluí-lo em si, aceitando-o como é.

As casas eram feitas com o material local, madeira, barro, pedras, palha. As ruas não eram construídas em função do trânsito de veículos, o que tornava desnecessária a economia de curvas. Tampouco eram imperativos os cruzamen- 
tos, nem obrigatório que as vias tivessem saída. Muitas vezes as sinuosidades labirínticas e as saliências aparentemente supérfluas, que aos olhos de hoje parecem convidar à criminalidade (mas que eram uma característica fundamental da cidade do medievo), existiam só porque uma árvore foi poupada, porque ventos excessivos foram abrandados, ou em virtude de um riacho, depois seco ou encoberto, ter sido aproveitado ou contornado. Positivamente, não se tratava de um urbanismo governado pela máquina de terraplanagem.

As cidades eram construídas, com constância, em cimos de colinas: mas era porque se queria ver o campo, avistar de longe os que chegavam e partiam, era em razão de se desejar seguir as sugestões do relevo, ou pelo fato de não se abrir mão de aproveitar as terras planas para o cultivo - as quais, segundo o ponto de vista de nossa urbanística contemporânea, pareceriam mais indicadas para edificar. Até que os mercadores viessem a aspirar a uma segurança mais efetiva, por volta do século XII, os muros que envolviam a cidade medieval eram de madeira e suas portas em geral tinham, do mesmo modo que os cumes das igrejas, funções muito mais simbólicas - marcação de fronteiras e expressão de visão de mundo - do que propriamente geográficas. As portas - e as cidades medievais normalmente dispunham de várias - representavam, em especial, lugares de encontro simbólico entre dois mundos que já se interpenetravam. Além disso, os muros também serviam de belvedere, pois ofereciam excelente perspectiva sobre o campo e permitiam o gozo das brisas de verão que não perpassassem a cidade. Com ressalva de alguns centros congestionados, a cidade não apenas estava no campo, mas era do campo.

A urbanística medieval não cortava a cidade do mundo. Não derivava de um projeto preconcebido, para a realização do qual todos os obstáculos eventuais deveriam ser removidos, mesmo que isto implicasse total aplainamento da paisagem e aniquilamento do que fosse 'velho'. Ela se fazia de obra em obra, por uma série de decisões pontuais e localizadas, definindo adaptações diversificadas que tinham, como característica mais ou menos invariante, exatamente esta diversidade. Cada cidade medieval surgiu de uma situação particular, apresentou uma constelação singular de forças e expressou em sua planta uma solução especial. A concordância medieval sobre os fins da vida urbana era de tal modo completa que as variações de detalhe se limitavam a confirmar o esquema geral. Havia, no improviso da planta urbana da Idade Média, uma inspiração filosófica e uma matriz cultural que são as mesmas que estamos acompanhando neste trabalho por diversas outras trilhas. Por este motivo, como qualquer viajante pode ainda hoje testemunhar, as cidades medievais, embora reservando surpresas a cada curva ou edificação, não resultaram em um urbanismo caótico ou mesmo sem encantos.

Talvez seja preciso registrar que raríssimas cidades medievais apresentavam dimensões aproximadas às que hoje associamos automaticamente à palavra (embora parcelas significativas das cidades espalhadas pelo mundo ocidental ainda vivam dentro de proporções semelhantes às do medievo). Na- 
queles tempos, poucas atingiam mais do que dois ou três mil habitantes. Eram cidades feitas para pedestres, o que favorecia em muito os pontos e as situações de comunicação direta. Raras atingiam um diâmetro de dois quilômetros, o que significa, na prática, que quase todos eram vizinhos, ao alcance do pé, da mão ou do acaso. A cidade medieval não cortava a sociedade de si mesma. Ricos e pobres necessariamente se esbarravam, nas ruas, nos mercados, nas catedrais, pois todos estavam acostumados à vida ao ar livre (Rossiaud, 1989).

A impressão que teríamos sobre o modo de vida medieval - encarnada na expressão tantas vezes repetida pelos historiadores - é de 'amontoamento'. As distâncias físicas reproduziam as distâncias sociais, uma vez que as disparidades de fortuna ainda não eram tão ponderáveis que chegassem a exigir a edificação de barreiras protetoras entre os homens. Esta é uma das funções que, mais tarde, viria a ser desempenhada em filigrana pelas ruas e pelas largas avenidas, com suas calçadas, nas quais os mais pobres continuariam pedestres, freqüentemente banidos do centro, enquanto os ricos seriam transportados com velocidade.

As primeiras ruas modernas prenunciam o que testemunharemos mais tarde: os ricos, isolados em seus veículos particulares, passarão a ter a sensação de uma inédita liberdade de movimento, mas também deixarão de acreditar que a paisagem urbana circundante tenha qualquer significado além de ser um mero meio, cuja finalidade é o próprio deslocamento. A velocidade e o encapsulamento em seus veículos fazem desaparecer a paisagem humana. Este distanciamento não representa apenas expulsão, gesto de força ou pragmatismo individualista. Contém uma sutil dimensão de sensibilidade, pois é muito mais fácil ser cruel, rigoroso ou objetificante com aqueles que são anônimos e que não podemos ver.

As ruas medievais, mesmo que para nossos padrões fossem ruidosas, estreitas e fedorentas, apresentavam uma enorme força de atração. Eram por excelência lugares de comunicação: eram ação, distração, sociabilidade, vida... As ruas constituíam espaços onde se praticavam os ofícios, os afazeres profissionais, as conversas, os espetáculos e as brincadeiras. A impressão que transmite a iconografia é a de que tudo se passava na rua. Esta não se opunha à intimidade da vida privada, sendo, ao contrário, uma espécie de prolongamento dela, como Philippe Ariès observou (1977).

Quando, bem mais tarde em nossa história, os artistas começaram a se esforçar para representar cenas do viver privado, foi o cenário das ruas que escolheram para as enquadrar: "talvez essa vida privada se passasse mais nas ruas que nas casas" (Ariès, 1977:198). Nestas, as fachadas mais bem cuidadas, as varandas, as janelas, as portas davam diretamente para as ruas. O mesmo acontecia com os quartos mais apreciados, inclusive nas edificações que dispunham de um pátio interno. Seu habitantes - artesãos, camponeses, nobres religiosos ou mercadores - tinham uma consciência mais vicinal do que local, mais local do que 
regional, e muito mais regional do que 'nacional'. A idéia de nação, ou de algo abrangente e transcendente às circunvizinhanças, veio dos intelectuais e foi imposta ao povo. Porém não se efetivou senão após 1800 .

Uma grande cidade, por exemplo Londres, no século XII, abrigava vinte e cinco mil pessoas, mas era excepcional. Assim mesmo, salvo o castelo e a ou as catedrais, poucas construções tinham o aspecto monumental que a arquitetura burguesa viria a introduzir. Mantinham-se, para retomar uma expressão de Lewis Mumford (1977: 389), "na escala do humano": em vez de poucas e gigantescas, as construções eram preferentemente pequenas e variadas - um bom exemplo são as numerosíssimas igrejas paroquiais, que muitas vezes não foram consideradas dignas de conservação. Naquela Londres, somavam-se cento e vinte e seis de tais edificações, pelas quais se dividiam descentralizadamente as funções religiosas e sociais que a igreja comportava.

Também constituem bom exemplo as habitações. Os cômodos únicos dos pobres serviam para todos os usos. Mas os cômodos múltiplos das residências dos ricos também eram utilizados do mesmo modo. Ainda se desconhecendo o sentido da privacidade, não se separavam nas habitações os interesses próprios dos interesses comuns. Não se repartiam nem as atividades nem as pessoas segundo áreas especializadas do espaço doméstico: nada de um lugar particular para o dormir, menos ainda para o sono privado; nenhum lugar específico para o comer, nem para a alimentação de determinadas pessoas individualizadas; não havia lugares destinados exclusivamente para trabalhar, receber visitas, ter relações sexuais, pensar...

Este amontoamento não tinha necessariamente a ver com pobreza. Era um modo de ser. Era implementação de padrões culturais que se manifestavam repetidamente, nas mais variadas esferas da existência - seja na superposição das casas, no apinhamento das ruas ou na utilização, por diversas pessoas simultaneamente, de uma mesma cama, de um mesmo prato, de um mesmo banco etc. Eis uma ilustração: a invenção da privada, no final do século XVI, constituiu, como sabemos, um aperfeiçoamento técnico fundamental para o cotidiano de nossas sensibilidades contemporâneas. Contudo, a absorção social desta inovação não foi nada rápida. Por muito tempo ainda, a 'privada' se conservou pública e as funções que aí se deveriam segregar continuaram misturadas com outras atividades do viver diário. Para termos uma idéia mais precisa, consideremos que mesmo a privada 'seca', com aura de novidade inglesa, só foi introduzida na França no século XVIII.

A respeito da tese da 'pobreza', o que dizer do fato de que o palácio de Versalhes, construído sem medir despesas, não possuísse privadas ou banheiros, que seus corredores, seus pátios, suas alas estivessem cheios de matérias fecais? Assim, as casas que conhecemos hoje, com seus cômodos e móveis especializados, representam uma modificação de mentalidade e sensibilidade posterior ao século XII e que apenas muito lentamente se difundiu pelo restante da sociedade, enfren- 
tando resistências em todos os estratos sociais. Não obstante, esta modificação definiu um ideal arquitetônico cuja realização até hoje é um indicador de privilégio de classe. O desejo de intimidade é uma invenção das classes dominantes, ponto central de uma mentalidade individualista e pedra angular de um sistema econômico e político. Não é apenas um progresso optativo: representa uma visão de mundo, a que cedo ou tarde todos deverão se submeter.

Tal situação, de uma cidade "na escala do humano", como se sabe, não perdurou. Uma das transformações mais evidentes do cenário europeu foi o crescimento da população. Em 1500 havia cerca de oitenta milhões de pessoas no continente. Em 1800 tal número foi para mais de o dobro, beirando os cento e noventa. Um dos correlativos desse crescimento numérico foi a urbanização, pois acarretava menos espaço nos campos, aumentando circularmente o poder de atração da cidade que oferecia mais oportunidades de trabalho - modo eufêmico de dizer que ela 'exigia' trabalhadores para sustentar os negócios e os modos de vida burgueses - além de agir mais incisivamente sobre os imaginários. Em 1500, segundo dados de Fernand Braudel (1975), havia apenas quatro cidades com mais de cem mil habitantes (Istambul, Nápoles, Paris e Veneza), mas em 1800 havia vinte e três. Em 1700, mais de três quartos da população britânica ainda vivia no campo; em 1851, os habitantes da cidade eram maioria (Thomas, 1988). Em Londres, para voltarmos a nosso exemplo, contavam-se quarenta mil pessoas no século XIV e mais de um milhão no princípio do XIX.

Se tivéssemos de percorrer Paris nos anos de 1640 ou Londres antes do grande incêndio de 1666, ficaríamos impressionados com a absoluta concentração humana em um pedaço geográfico considerado minúsculo pelos padrões modernos. As casas se aglomeravam em ruas que não tinham mais de três metros e meio de largura, com inesperadas clareiras de vastos espaços abertos. De fato, à medida que nos aproximássemos das novas construções, vizinhas aos muros de Paris, ou da terra-de-ninguém situada entre a City de Londres e Westminster, não veríamos uma gradativa diminuição na concentração de casas, mas uma quebra repentina; passaríamos de ruas apinhadas a casas isoladas, dispostas praticamente como propriedades campestres.

Após o grande incêndio em Londres e na década de 1680 em Paris, a aglomeração populacional nas duas cidades começou a tomar uma nova forma. A terra queimada ou ociosa não foi pura e simplesmente ocupada. Foi reorganizada de acordo com um novo princípio, o da praça: uma praça radicalmente distinta das existentes nas pequenas cidades medievais, tanto em aparência quanto em função. Os princípios de design das praças em Londres romperam com o passado medieval de um modo bastante diverso dos que caracterizaram as praças parisienses. Mas essas duas revoltas contra passado levaram à mesma finalidade social (Sennett, 1989).

Menos visível, mas não menos importante do que este desenvolvimento das cidades, foi um conjunto de modificações econômicas que ficou conhecido como revolução comercial, que configurou em grande medida a consagração do 
capitalismo e de sua cultura, materializando-se por uma inédita expansão do comércio dentro da Europa, entre cidades e campo, das cidades entre si e mesmo com o resto do mundo. Associada a isto, houve uma grande modificação nas redes de comunicação e de transportes, bem como nas relações entre as culturas urbanas e rurais, fazendo com que a variedade cultural da Europa fosse gradualmente substituída pela homogeneidade do Estado e de uma cultura mais ou menos cosmopolita. Ainda assim, para não exagerarmos as coisas, é necessário lembrar que, não obstante todas essas mudanças, em 1800 menos de três por cento da população européia viviam em cidades com mais de cem mil habitantes e que essas pessoas, na maioria, ainda trabalhavam em oficinas e pequenos ateliês, e não em grandes fábricas.

As tendências, contudo, já estavam bem claramente assinaladas. $\mathrm{O}$ desequilíbrio do terceiro plano, a que fiz referência no início deste capítulo, mostrava-se cada vez mais nítido. Os muito ricos iam ficando ainda mais ricos e se separando dos pobres. Entre as cidades e os campos, o fosso não cessava de aumentar. A elevação contínua do nível de existência, a partilha desigual dos frutos, a diferenciação dos papéis sociais avivaram o contraste entre cidades e campos, casas ricas e casas pobres, masculino e feminino, enquanto a circulação sempre mais rápida dos homens e das idéias fazia esfumarem-se os particularismos locais e regionais, além de propagar de um extremo a outro do Ocidente modelos de comportamentos uniformizados (Duby, 1991a). Quando estes particularismos locais ou históricos antepunham obstáculos efetivos, as novas tendências respondiam com o mais simples e direto dos métodos, atacando-os em seu primeiro plano: a destruição.

Na cidade medieval não se encontrava normalmente uma autoridade central que ditasse os caminhos e os modos de sua expansão. Textos fixando normas de comportamento urbano começaram a aparecer no decurso do século XII; burgomestres e maires comunais eram, de acordo com Henri Pirenne (1964), de criação relativamente recente, não encontráveis muito antes do século XIII. As ameaças de multa para os que lançassem lixo sobre o solo urbano começaram a aparecer em Paris no final do século XIV, e foi de 1388 a primeira lei inglesa sobre higiene pública.

Tais inovações pertencem a uma época em que o espírito das instituições tendia a se modificar, em que as assimetrias sociais possibilitavam maior centralização e poder mais independente. Gradativamente foi-se formando um direito urbano, mais duro e severo que o das localidades camponesas. Nas palavras do mesmo autor, esse direito

prodigaliza os castigos corporais: enforcamento, decapitação, castração, amputação de membros (...) propõe-se a reprimir os delitos pelo terror (...) a cidade encontra-se, por assim dizer, em estado de sítio permanente (...) impõe a todos sua impiedosa regulamentação (...) a cidade forma um território jurídico distinto (...). (Pirenne, 1964:153-154) 
No século XVII, René Descartes já sintetizava, na segunda parte de seu Discurso sobre o Método, as direções do processo urbano, afinando-o com as transformações culturais e políticas de seu tempo, e já prenunciando o barão Haussmann:

É constatável que as edificações que um único arquiteto planejou e executou são de modo geral mais elegantes e cômodas que aquelas que vários tencionaram melhorar fazendo uso de velhas paredes construídas para outros fins. Também as antigas cidades que, sendo no princípio apenas aldeias, tornaram-se no correr dos tempos grandes cidades, são geralmente mal traçadas em comparação às cidades regularmente construidas que um arquiteto profissional planejou livremente, numa planície aberta; desse modo, embora os vários edificios das primeiras possam muitas vezes igualar ou superar em beleza os das últimas, quando se observa sua justaposição indiscriminada, ali um grande prédio aqui um pequeno, e a conseqüente sinuosidade e irregularidade das ruas, fica-se disposto a admitir que o acaso, mais que qualquer vontade humana guiada pela razão, deve ter levado a uma tal disposição (...).

Eis-nos, pois, na 'cidade da Razão', com seu planejamento impositivo. Eisnos na 'capital', com suas grandes e planas avenidas; com suas linhas retas e homogêneas. Eis-nos na cidade em que cada espaço desenvolve uma atividade particular especializada, a cidade atomizada. Eis-nos diante do poder centralizado e absoluto, com seus cenários desenhados para a circulação rápida das elites e para os desfiles militares ostensivos e solenes.

Não foi preciso esperar pelos golpes mortais da Revolução Industrial e sua eficiência mecânica para que o crescimento dos núcleos urbanos, a melhoria das estradas, a alfabetização e, sobretudo, a aristocratização das cidades fizessem sentir seus poderes destrutivos sobre os campos e os pequenos centros locais, cerceando a liberdade e a diversidade destes. Os preconceitos que materializam tais relações de poder emergiram imediatamente e se fortaleceram aos poucos. Assim, o camponês (e, por extensão, o popular) passou a ser visto de modo pejorativo já por volta do século XII. Por essa época, ele começou a ser tratado como rusticus, tornando-se sinônimo de ignorante, de iletrado, de vicioso, de perigoso, de sujo, acusado de permanecer mais próximo do animal que do homem. Em suma, o camponês foi sendo paulatinamente reduzido a simples contraponto das elites que, por seu lado, passaram a se considerar como cultas e urbanas. 


\section{7 \\ Higiene e Vigilância}

Amontoamento, interpenetração, mistura, amálgama... Estes são alguns dos termos que tenho reiteradamente utilizado para caracterizar os aspectos fundamentais do universo cultural medieval, bem como das mentalidades e sensibilidades a ele associadas. A nova sensibilidade se constitui basicamente em ruptura com os princípios medievais e se define simbolicamente por oposição a estes.

No essencial, essa constituição assumiu a forma de um contínuo processo - ainda muito longe de estar terminado - de fragmentação daquele todo amalgamado que a cultura medieval configurava. Em outras palavras, poder-se-ia dizer que o processo de emergência disso que denominamos modernidade e contemporaneidade se deu antes de tudo pelo aparecimento - nos comportamentos, nos pensamentos e nos sentimentos das pessoas - de esferas mais ou menos autônomas, nas quais se supõe residirem experiências relativamente independentes. Autonomização e fragmentação, ali onde a mentalidade medieval via confluências e superposições.

Tais fragmentações se materializaram, por exemplo, na separação entre um mundo terreno e um mundo divino. A partir de certo momento, mas não de modo imediato, plenamente convicto e sem resistências, um número cada vez maior de homens passou a sentir ou imaginar que existe uma lógica das coisas deste mundo e que esta não coincide com a dos assuntos celestiais. A antiga imbricação entre o imanente e o transcendente deu lugar a uma espécie de cisão. Um outro exemplo desse processo de autonomização podemos encontrar na gradativa separação que se estabeleceu entre as esferas do público e do privado. Para ilustrá-la, basta-nos figurar as transformações por que passou a cerimônia medieval da morte, na qual a cena coletiva, aberta a todos, foi-se metamorfoseando no acontecimento isolado de hoje, que se abate sobre alguém, quase sempre solitário, fechado em um centro de tratamento intensivo de algum hospital, no qual nem mesmo filhos e cônjuges podem penetrar. Já falamos da separação entre corpo e alma, espírito e matéria, pela qual o "creio na ressurreição da carne" foi deixando de prevalecer, substituído pela concepção de um corpo mortal, fadado à degradação, dejeto imprestável se comparado a um espírito imortal que deverá continuar a viver pela eternidade. 
Deu-se também a separação entre sãos e doentes. Criaram-se manicômios, hospitais, prisões, onde se deveriam doravante alojar os portadores de diferenças, que assim poderiam mais facilmente ser alvo de olhares objetivadores e vigilantes. Podemos lembrar ainda, a título de ilustração, a separação entre adultos e crianças: como resultado, inventou-se um mundo específico de homens e mulheres adultos, totalmente diferente do universo infantil, que agora passou a carecer de isolamento em colégios, onde as crianças se tornaram objeto de estratégias e metodologias bastante especiais, inspiradas no rompimento com a velha pedagogia medieval, que era baseada na imitação e apropriada a uma sociedade em que todos se misturavam (Ariès, 1978). Poderíamos ainda falar da separação dos corpos entre si, do afastamento entre os homens e seus próprios corpos, da especialização dos cômodos das residências, da fratura entre os locais de trabalho e os de relações familiares etc. No momento, não vale a pena nos determos por demais nestes pontos: já tratamos de alguns e retomaremos outros adiante.

Seria importante ressaltar, não obstante, que este movimento de fragmentação do universo medieval fez-se acompanhar de um processo paralelo, ou imediatamente posterior, de formação de domínios específicos de saberes, relativos a cada uma das esferas que se autonomizavam. Por esta via, se o mundo natural e o divino se divorciavam, logo advieram saberes destinados especificamente à compreensão da natureza, bem como uma teologia voltada quase exclusivamente ao desvelamento dos mistérios de Deus. De modo análogo, com a separação entre o indivíduo e a sociedade, surgiram as disciplinas especiais almejando capturar as lógicas particulares e respectivas dessas esferas.

A regra fundamental desse processo é a fragmentação. Por isso, os domínios que se separaram progressivamente se subfragmentaram. Supõe-se que os subdomínios resultantes também seriam dotados de lógica própria, cada uma objeto de um saber específico, formando as sub-especializações (ou super-especializações, tanto faz) que vieram a conformar o quadro de disciplinas e especialidades que hoje conhecemos bem e que a cada dia nos surpreende com novas subsub-especializações. No domínio da sociedade, por exemplo, assistimos à autonomização das esferas da economia, da política e das relações sociais: para cada uma delas, saberes especiais e subespecíficos, arvorando-se em proprietários privados dos lotes do mundo que proclamam ter como objeto. Que dizer, então, de domínios ainda mais especializados, como os das ciências físicas, biológicas ou, mais próximo da experiência leiga de cada um de nós, para nossa desorientação, da medicina?

Desse modo, como não poderia deixar de ser, a história de nossos saberes, de nosso arsenal científico, de nossas disciplinas, de certa forma e em grande parte é a história da própria constituição de nossa sociedade. Tal conjunção, entre a história de nossas ciências e a de nossas instituições, permite-nos - ou mesmo obriga-nos a - lançar uma dúvida dramática sobre a capacidade que este aparato 
teria para compreender a sociedade que o gerou (Baudrillard, 1973). Na verdade, este aparato mais expressaria esta sociedade, sua visão de mundo, suas instituições, do que a compreenderia como objeto. Seria como o olho: capaz de ver apenas dentro dos parâmetros ditados por sua estrutura interna e incapaz de se enxergar a si mesmo. Que esta ressalva sirva inclusive para as análises a que estou procedendo.

Dentre as fragmentações que modificaram o cenário medieval, gostaria, no momento, de colocar em evidência, pelo que tem de estratégica para o tratamento de nossa temática, a cisão que se deu entre o campo e a cidade, entre o rural e o urbano. Com a emergência da cidade que desconhece o campo, uma curiosidade particular, um saber específico sobre o urbano apareceu, não apenas buscando compreendê-lo, mas também defini-lo como algo radicalmente diferente daquilo que o precedera. Nessa cidade, em que se aceleravam as tendências históricas a que estamos dedicando nossa atenção, uma das mais importantes preocupações era 'separar'. Isto se deu de modo embrionário até o século XIV, mas foi uma exigência cada vez mais atuante a partir dos séculos XVII e XVIII. Contra o amontoamento, pretende-se agora destinar para cada modo de vida, para cada tipo de ser, para cada condição social, para cada forma de atividade, para cada função social, um lugar específico e um tempo predeterminado. A esta pretensão vêm responder os hospitais, as escolas, os presídios, os bairros populares, os salões de festas, os locais de trabalho, as calçadas, as ruas retas...

Voltando a um ponto que abandonei provisoriamente algumas páginas atrás, é importantíssimo observar que esses movimentos em geral são contemporâneos da grande e paradigmática obsessão européia de isolar os mortos. A preocupação mais fundamental dos urbanistas e higienistas, das mentalidades modernas e vanguardistas do Século das Luzes, foi colocar os mortos fora das cidades, de certo modo retomando uma tradição romana, da qual a Via Appia, em Roma, é hoje uma bela ilustração. Esta tradição, como vimos, foi abandonada nos tempos medievais, quando se passou a ter os mortos dentro das cidades, convivendo com os vivos no centro da vida comunitária. A Igreja, recordemos, sempre foi contrária a esses hábitos medievais, as autoridades eclesiásticas manifestando repetidamente o horror que sentiam contra tais práticas, que consideravam eminentemente pagãs. Antes dos higienistas, portanto, um poder se opunha a esses costumes mas a repetição das censuras, não obstante, apenas sugere, ao olhar sutil, que as regras ditadas do alto encontravam pouca ressonância prática e que as populações permaneciam em grande parte indiferentes.

No final do século XVIII, essas condenações passariam a encontrar eco, embora pronunciadas por outros poderes e sustentadas por novos argumentos. Em quase toda a Europa, mais ou menos simultaneamente, desencadeou-se um processo vigorosíssimo de expulsão dos cemitérios. Em Paris, por exemplo, em 1780, exumou-se todo um cemitério, o dos Inocentes, que era o principal da cidade 
(Ariès, 1975; Crespo, 1990). Das entranhas da terra extraíram-se multidões e multidões de restos que ali dormiram durante séculos. Tudo isso apenas com o objetivo de transferi-los para fora da cidade. Olhando para trás, com dois séculos de distância, pode-se perceber que começou naquele momento, de fato, uma batalha até hoje não terminada e que ameaça atingir dimensões dramáticas: a que põe frente a frente a expulsão dos restos e o crescimento das cidades. Sua lógica é simples, contraditória e elementar: o cemitério e os restos são colocados fora da cidade; esta se expande e eles retornam ao interior urbano.

Esta lógica e este movimento são completamente contemporâneos da lógica e do movimento de banimento do lixo. A expulsão dos Inocentes data de 1780, enquanto o primeiro projeto de reunião e afastamento do lixo urbano foi de 1779: um ano apenas separa esses dois gestos que, em essência, representam a mesma coisa. Tanto na expulsão dos mortos como na do lixo, o mesmo drama estava em questão: os restos do século XVIII ainda eram fundamentalmente orgânicos, e o que se queria afastar em ambos era a evidência do transcurso do tempo biológico, a presença da decomposição, a memória orgânica perpetuada no solo. Há em tudo isso uma grande ameaça aos novos sonhos de acumulação de riquezas, de vida e de progresso.

Para entendermos as mentalidades e sensibilidades desta época é importantíssimo ter em mente que, neste tempo, o fundamental dos perigos vem do subsolo. Toda ameaça vem do ventre da terra: os homens 'de vanguarda' das cidades do século XVIII detestam especialmente os pântanos, os cemitérios, os poços, os afloramentos, em particular os de lama ou óleo, as fendas, sobretudo as da terra e, ainda mais, as abertas pelos tremores... Entre as acusações que dali em diante serão dirigidas contra o lixo, figura em destaque a que lhe atribui a faculdade de favorecer, como que por osmose, a impregnação do solo e os afloramentos de matéria orgânica em decomposição. Em ambos os casos - expulsão dos mortos, expulsão do lixo - o que está em evidência é o sentimento de angústia diante da morte.

Ressaltei há pouco a expressão 'de vanguarda' porque na prática, apesar da obsessão nascente, o ambiente urbano do século XVIII ainda era predominantemente o da cultura medieval (Attali, 1979): o da carniça, do estrume de animais que circulavam dentro do perímetro urbano, dos restos de alimentos, do sangue que escorria pelos cantos ou que permanecia estagnado nas poças, dos cadáveres de grandes e pequenos animais, dos fedores dos sebos sendo derretidos, dos matadouros dentro das cidades, provocando febres pútridas, dos hospitais desencadeando gangrenas úmidas cujas feridas não cicatrizavam, dos cemitérios empilhando dejetos e corpos, dos açougues, dos curtumes, das cozinhas coladas umas às outras, dos excrementos lançados às vias públicas...

Deve-se registrar, entretanto, para não mergulharmos no etnocentrismo preconceituoso, que aquela cidade-ainda-campo, que era a medieval, também oferecia a seus habitantes os perfumes dos jardins, das hortas e dos pomares, o canto 
dos galos e dos passarinhos, a sonoridade dos moinhos d'água, o rumor dos córregos e cachoeiras, o farfalhar das folhas das árvores, a vista dos campos verdes ou da brancura da neve, as sempre audíveis cantigas religiosas e de trabalho...

Comparativamente, nenhum lugar do novo espaço urbano escapava à pestilência. Em virtude do crescimento pós-medieval das cidades e das novas condições ecológicas ditadas pelo distanciamento dos campos, essa pestilência era ainda muito maior do que aquela que relatávamos a respeito das pequenas e semirurais cidades da Idade Média. Neste ponto, por um prisma comparativo, devemse matizar as coisas e pode-se até mesmo dizer que as cidades medievais foram injustamente acusadas de insalubres (Mumford, 1961, 1977). Especialmente pela supressão de espaços livres dentro das cidades modernas e pela disseminação de prédios de vários andares, dessa nova pestilência não escaparam os teatros, não escapou a Assembléia Constituinte da Revolução, não escaparam os tribunais, as igrejas, o palácio real e particularmente, ainda, não escaparam os cemitérios, com seus amontoamentos de cadáveres cada vez mais numerosos, em territórios cada vez mais exíguos.

Esta página do romance de Patrick Susskind, O Perfume, sintetiza para nós o ambiente sensorial do Século das Luzes:

(...) reinava nas cidades um fedor dificilmente concebivel por nós, hoje. As ruas fediam a merda, os pátios fediam a mijo, as escadarias fediam a madeira podre e bosta de rato; as cozinhas, a couve estragada e gordura de ovelha; sem ventilação, as salas fediam a poeira, mofo; os quartos, a lençóis sebosos, a úmidos colchões de pena, impregnados do odor azedo dos penicos. Das chaminés fedia o enxofre; dos curtumes, as lixivias corrosivas; dos matadouros fedia o sangue coagulado. Os homens fediam a suor e a roupas não lavadas; sua boca fedia a dentes estragados, seu estômago fedia a cebola e, o corpo, quando já não era mais bem novo, a queijo velho, a leite azedo e a doenças infecciosas. Fediam os rios, fediam as praças, fediam as igrejas, fedia sob as pontes e dentro dos palácios. Fediam o camponês e o padre, o aprendiz e a mulher do mestre, fedia a nobreza toda, até o rei fedia como um animal de rapina, e a rainha, como uma cabra velha, tanto no verão quanto no inverno. Pois à ação desagregadora das bactérias, no século XVIII, não havia sido colocado ainda nenhum limite e, assim, não havia atividade humana, construtiva ou destrutiva, manifestação alguma de vida, a vicejar ou a fenecer, que não fosse acompanhada de fedor (...).

É preciso termos sempre em mente que o ritmo de transformação quantitativa das cidades foi muito maior que o da metamorfose das mentalidades e sensibilidades. E que os hábitos e as formas de vida medievais, incompatíveis com as novas dimensões da cidade, eram ainda plenamente operantes mais de três séculos depois do 'fim' da Idade Média - que, aliás, só 'terminou' em 1453 por decisão dos historiadores do século XIX. Ademais, as características medievais 
doravante coexistem, sobretudo nas cidades de índole industrial, com os odores também fétidos do carvão queimado, das fumaças que escurecem o ar, dos gases gerados em larga escala pela fermentação já industrial de cervejas, com a fabricação de tijolos, com as poeiras levantadas pelas rodas dos veículos, com as exalações sulfurosas das fábricas... Tais odores parecem-nos mais suportáveis apenas por serem os 'nossos'. É compreensível, mesmo assim, que nesse novo contexto urbano, logo tenha surgido, ao lado do "horror por respirar os miasmas da cidade" (Corbin, 1987:10), uma certa nostalgia do rural, e que os urbanistas tenham começado lentamente a se preocupar em recolocar um pouco de campo (jardins, bosques, parques etc.) dentro das cidades (Thomas, 1988).

Foi quase como uma verdadeira revolução que, nesse ambiente, as autoridades resolveram deslanchar uma espécie de cruzada de desodorização e de limpeza, para banir as 'imundícies' que uma sociedade cada vez mais hierarquizada tolerava cada vez menos. O cargo de intendente-geral de polícia foi instituído na França em 1665 e em 1757 se definiu um primeiro 'código de polícia', cujo objetivo era fazer que as pessoas vivessem 'civilizadamente', isto é, de modo cultivado, polido ou refinado, excluindo tudo o que parecesse bárbaro, irracional ou governado pela confusão. 'Polir' (limpar), 'policiar' (vigiar), ser 'polido' (bem educado), 'política' (poder) pertencem ao mesmo campo semântico e se entrelaçam no mesmo processo histórico de vigiar, inspecionar, relatar, delatar, alertar, controlar, regulamentar, proibir, intervir, constranger... Não obstante, devemos considerar que contra mentalidades tão fortemente enraizadas dificilmente há repressão eficaz a curto prazo.

Assim, o termo 'política' se insinua bastante lentamente e não se torna uso corrente, como substantivo, senão depois do século XVII. Consolida o uso do adjetivo, já verificável desde o século XVI. Jacques Le Goff oferece-nos um esclarecimento bastante preciso sobre este ponto, em que as dimensões macro e microscópica do social se entrelaçam. Le Goff nos ensina ainda que a palavra 'política' se beneficiou do destino dos vocábulos relacionados com o conceito de polis. Estes, juntamente com os derivados de urbs - urbano, urbanidade, urbanismo -, recobrem uma larga área do campo semântico de 'civilização'. E é talvez através de police que se produziu policé (organizado, civilizado, no século XIX), que se chega a politesse (gentileza, delicadeza), que aparece no século XVIII. "O reino do político, da política e dos políticos (política teórica, política prática, personalidades políticas) é, portanto, o reino da élite, e foi aí que a história política foi buscar a sua nobreza. Fazia parte do estilo aristocrático" (Le Goff, 1985:225).

No século XVII, a palavra 'limpo' começa a adquirir conotações morais, passando a significar também distinção, elegância, ordem (Vigarello, 1985). A limpeza das coisas torna-se indicador de limpeza da alma e crescentemente se admite que um povo limpo é também ordeiro e disciplinado. Nesse caminho, a primeira cadeira de Higiene Pública foi criada em Paris em 1794 (Corbin, 1987), 
tendo por finalidade investigar coisas como: por que razão os rios fedem, o que fazer com as fossas sépticas, de que modo lidar com os lugares de aglomeração, como proceder com relação às ruas, de que maneira desamontoar aquilo que a herança medieval permitia ainda misturar e confluir etc. Tudo isso ia na direção de colocar cada coisa em seu lugar. Tudo isso era inspirado pela vontade de fragmentar, definir, organizar, classificar, projetar.

Já em 1779 a limpeza das ruas de Paris se torna tema de concurso científico, em uma tentativa de envolver os sábios na exploração dos problemas de lixo e esgoto. Em seguida, por volta do começo do século XIX, a palavra 'higiene' passa a ter um lugar anteriormente inusitado, transformando-se em disciplina especializada no campo da medicina e das políticas públicas. Mais do que isto, a higiene se associa com freqüência à polícia e às autoridades militares, pois seu trabalho é visto como uma espécie de policiamento sanitário, uma defesa contra as investidas de terríveis inimigos, um combate, ou um ataque radical às causas da poluição. Em ponderável medida, a argumentação de base desse novo campo de saber consiste ad nauseam em atribuir a maioria dos males à ausência de controle.

Como uma das primeiras providências para lidar com o solo urbano, surge a idéia de pavimentar as ruas. Pavimentar ao máximo, tantas quanto possível. Cobrir o solo urbano, obstar as águas estagnadas, a lama, o lodo, os pântanos com águas putrefatas e suas matérias orgânicas em decomposição - perigosos e numerosos, sobretudo no verão. Canalizar os rios, os esgotos, as urinas, os excrementos, as águas utilizadas. Fechar tudo isso em um circuito. Fazer que tudo isso tenha paradeiro bem longe, fora da cidade, de preferência. Fazer com tudo isso o mesmo que se quer fazer com o lixo e com os mortos: expulsar. As campanhas de pavimentação dos solos não pouparam nem mesmo as cabanas de camponeses, as aldeias e as sepulturas: o objetivo é cobrir o chão, tanto chão quanto for possível, de modo a criar uma espécie de linha divisória, sólida e compacta, que separe a superfície em que vivem os homens do subsolo úmido, perigoso, nauseabundo.

Um novo temor nasceu, a que Michel Foucault chamou "medo urbano" (1982:87). A partir daí as coisas começam a acontecer rapidamente. Depois da Revolução Francesa, as ruas, pelo menos as mais centrais e importantes, são alargadas e pavimentadas. Os prédios, obedecendo ao novo ideal de separar, passam a ser construídos com espaçamentos entre si. Muito é destruído e reconstruído. Os esgotos, raramente contemporâneos da fundação de uma cidade, são instalados. Populações são deslocadas, de maneira que os bairros das populações pobres, ainda mais profundamente envolvidas pelas mentalidades e sensibilidades anteriores, fossem afastados dos quarteirões destinados às elites, que ficarão, doravante, relativamente preservadas daquele odor que ainda permanecerá em certas esferas da sociedade.

Os espaços mais visados são hospitais, matadouros, cemitérios, prisões todos associados à morte e ao apodrecimento, locais agora considerados como abcessos sinistros no tecido urbano. Nesse ponto começa a ligação insistente 
entre o fedor e a sujeira dos espaços e dos corpos. Como o lixo e os mortos, banidos são também, de certo modo, os pobres, os desviantes e os doentes. $\mathrm{O}$ olfato se transforma, por esta via, em importante sensor de limites sociais. Tornase definidor de xenofobias. Erige-se em crucial determinante da geografia urbana.

É interessante observar que em seu trabalho sobre as profissões lícitas e ilícitas na Idade Média, Le Goff (1980) não menciona os lixeiros. Não se trata de omissão ou esquecimento: a figura do lixeiro não é tão antiga. Emergiu em Paris no segundo quartel do século XIX, porque naqueles anos a cidade ficou quase literalmente sufocada pelo lixo. O lixeiro surgiu como um personagem importante do imaginário social, herói de muita literatura, figura de vanguarda, a concretizar e materializar um mundo novo, em parte já anunciado e prefigurado. Cerca de cinqüenta anos antes da criação da profissão de lixeiro, entretanto, esta prefiguração já elaborava os seus projetos.

Reproduzindo bem o espírito do tempo, alguns desses projetos imaginavam fazer com que os dejetos sociais rendessem alguma coisa, obrigando-os a eliminar os dejetos econômicos (Corbin, 1987): vários e vários planos foram formulados, almejando que prisioneiros, loucos, velhos, doentes, camponeses etc. se encarregassem da tarefa de recolher o lixo e de removê-lo para fora da cidade. Vários outros planos idealizavam inserir o lixo e excrementos no âmbito dos negócios, calculando ou especulando seus valores no mercado, como poupança ou como investimento. Assim, foi praticamente em 1846 que se oficializou de modo efetivo na França a idéia de que o lixo merecesse um tratamento de autoridade, que devesse ser considerado na política pública, que fizesse jus a um orçamento específico, que pudesse ser profissionalizado, que fosse objeto de um estudo especializado... Há apenas cento e cinqüenta anos!

A transição, contudo, não se deu de maneira abrupta ou repentina. O primeiro projeto de instalação de lixeiras nos pavimentos dos edifícios de Paris data de 1859 (Guerrand, 1991). Até o final do século XIX, alguns seminários médicos ainda especulavam seriamente sobre as virtudes terapêuticas e regeneradoras disso que chamamos de lixo. Vários médicos insistiam em pensar que as feridas poderiam ser curadas se o paciente mergulhasse, por exemplo, uma perna ferida no esgoto, nos poços, em excrementos. Eco dos velhos tempos medievais, nesse contexto histórico ainda alguns acreditavam que os restos fossem dotados de virtudes tonificantes intrínsecas.

Em contrapartida, outros médicos, 'modernos', já eram críticos ferozes das condições de vida populares, sobretudo das que associavam aos camponeses (pés descalços, ambientes abafados e cheios de fumaça, proximidade com lamas, excrementos e animais, economia na troca de roupas, utilização coletiva das camas, partilha destas com animais, mistura de pessoas sãs e doentes, presuntos pendurados nos tetos, sedução pelos odores orgânicos etc.). Por seu lado, essas camadas preferiam muitas vezes os velhos curandeiros, agora acusados de charlatanismo por médicos que, a partir de 1892, passaram oficialmente a deter o monopólio da cura. 
Tão próximo de nossos dias, havia ainda um ambiente pleno de ambigüidade, mesmo no território dos sábios, quanto à posição do lixo e da sujeira - se fastos ou nefastos. Como sabemos, com o tempo foram predominantemente considerados nefastos. No final do século XIX, já se falava seriamente em 'resistência do povo' - o que significa simplesmente que este, em medida razoável, ainda dedicava diminuta confiança à nova medicina. Entrementes, lixo e sujeira persistiam nos cotidianos, como algo com cuja presença se podia - ou mesmo se deveria - conviver.

No âmbito deste quadro urbano, que pretendia separar orgânico de inorgânico, útil de inútil, que desejava classificar e localizar, compreende-se que o ar e a água constituíssem elementos perigosíssimos. Era fundamentalmente mediante estes dois canais que se acreditava que o contágio e a infecção se dessem. Até 1750 prevaleceu a teoria de que o ar fosse uma substância única (Corbin, 1987), ninguém se tendo convencido naquele momento de que representasse um composto de gases. O processo intelectual de fragmentação ainda não o havia atingido.

Desse modo, imaginava-se que o ar contivesse em si a substância na qual tivesse tocado ou da qual emanasse. Seus diversos aspectos (cheiro, temperatura, umidade etc.) eram atribuídos ao fato de ser parte daquilo de onde supostamente saíra. Um tema freqüente por volta de 1770 acusava os eflúvios pútridos de difundirem a morte em ambientes fechados. Imaginava-se que o ar pudesse agir de múltiplas maneiras sobre os corpos vivos. Por exemplo, temia-se que crianças viessem a morrer dentro de igrejas por causa das emanações das sepulturas. Tais exalações, agora, são tidas por malignas; o odor das carnes em decomposição pode ser mortal. Nesse novo contexto, os mortos passam a ameaçar os vivos fisicamente.

A nascente medicina urbana, como observou Foucault, "não é verdadeiramente uma medicina dos homens, corpos e organismos, mas uma medicina das coisas: ar, água, decomposições, fermentos" (1982: 92). Compreende-se, por este caminho, que os perigos atribuídos à água e ao ar nada tivessem de aleatório, pois a primeira, pelo deslizamento, e o segundo, pela circulação, colocavam sob evidente ameaça a repartição de domínios sobre a qual se assentava o novo bemestar. Ar e água têm características de mobilidade, de romper limites; guardam em si a potencialidade de comparecer insidiosamente em território impróprio. Era necessário e importante evitar tanto quanto possível sua circulação, pois estas substâncias móveis desafiavam e desacreditavam a fixidez e a solidez das separações que as novas mentalidades pretendiam estabelecer.

Aí está a razão pela qual os gases que emanavam do subsolo devessem ser vedados: a invasão do urbano que cometiam era como se o próprio subsolo a tivesse praticado. Tornava-se imperativo confinar as funções excretórias em locais especiais, a fim de que os gases portadores dos odores que eram parte dos excrementos não traíssem o sistema de separações, visitando indisciplinadamente 
domínios de que deveriam estar reciprocamente apartados. Neste ponto, como registrei, o olfato passa a ter uma importância fundamental na história da sensibilidade. $\mathrm{O}$ fedor não apenas incomoda; passa a ser perigoso.

O grande pavor punha em evidência tudo o que pudesse permitir infiltrações: as fendas dos calçamentos e os interstícios das paredes, pois poderiam deixar passar a umidade; os porões que ameaçavam, pois poderiam se embeber das águas do subsolo. Era preciso tomar cuidado com as madeiras, uma vez que passíveis de se impregnar de líquidos e cheiros - como acontecia com as mesas dos açougueiros e peixeiros, freqüentemente lembradas como exemplos. Causavam pavor as inundações, em virtude de espalharem pela superfície coisas pertencentes a domínios díspares e imisturáveis, turvando a ordenação classificatória que se pretendia ver presidindo o cenário urbano.

Em semelhante contexto, as palavras de ordem eram 'tampar' e 'fechar'. Fechar as narinas seria um último recurso, mas era prioritário agir sobre o ambiente. As paredes, por exemplo, passaram a ser revestidas de reboco, forradas ou caiadas e cobertas de tinta. As sepulturas, majoritariamente, passaram a ser cobertas de lápides, tijolos e cal. Uma atenção particular ao calçamento urbano e seus buracos assumiu posição especial e privilegiada. Nas casas, começou-se a cobrir os tijolos que tivessem contato direto com o chão, pois estes eventualmente podiam ter absorvido os miasmas e as substâncias destrutivas que provêm do interior da terra. As madeiras, quando havia, eram crescentemente substituídas por materiais impermeáveis, cobertas de camadas de verniz ou de esmalte, a fim de que se as pudesse facilmente enxugar.

Essas iniciativas se deram em nome da grande preocupação sanitária do tempo, que era impedir a circulação de ar e de água. Já disse que, por esse expediente, objetivava-se antes de tudo manter a separação de domínios. Ao lado disso, é evidente que se almejava também, e principalmente, em nome dos "medos urbanos", impedir a circulação de pessoas, pois no frigir dos ovos era essa a questão de que se tratava: colocar os miseráveis, os mendigos, os pobres em seus lugares 'corretos'; fazer o mesmo com os doentes e com os loucos; classificar doentes e doenças, destinando-lhes enfermarias específicas e impedindo o embaralhamento de categorias diferentes. Colocar portas, fechaduras, construir paredes, improvisar cortinas - eis apenas alguns dos instrumentos de materializar os mencionados objetivos.

Trata-se de movimentos, gestos, providências nada aleatórios. Tudo isso contém uma lógica cultural e política muito específica. Esta lógica apareceu antes da descoberta pasteuriana dos microorganismos patogênicos. Após Pasteur apenas se desdobrou, aplicando-se agora particularmente aos corpos portadores de 'micróbios'. É claro que esses portadores por excelência são os pobres, pois, doravante, evocar a limpeza será fundamentalmente opor-se às negligências populares, aos fedores orgânicos, às promiscuidades descontroladas. 
Ao mesmo tempo, por uma lógica circular, as acusações de periculosidade de que os pobres são objeto racionalizam, justificam e até mesmo desculpam o distanciamento e o nojo que as elites passam a nutrir em relação a eles: há, doravante, 'de fato', algo 'material', 'biológico'; constatar-se-ia um perigo 'objetivo'; 'existe um risco 'efetivo' de infecção decorrente do contato com as classes subalternas - e com os micróbios que se arrisca delas adquirir, ainda que pelas vias mais sutis e delicadas.

Talvez seja novidade, para boa parte dos leitores, que as coisas tenham acontecido assim. É que, adiante, em fins do século XIX e início do XX, pensarse-á de modo totalmente diferente, a respeito de pontos específicos desta questão. Então, as pessoas já estarão habituadas a um certo silêncio olfativo e considerarão que o ar (entendido de outro modo) seja positivo. Pensarão agora que seja recomendável aos doentes que respirem ar puro, em particular o da montanha (oposto ao do subsolo). Acreditarão que as casas devam ser arejadas. Almejarão que as residências familiares sejam individuais. E advogarão que as construam preferentemente separadas umas das outras, para que o ar possa fluir livremente entre elas...

Alguns vão até mesmo sonhar com máquinas de agitar o ar, espécie de gigantescos ventiladores, ou imensas pás de moinho, para arejar as cidades e expulsar os gases deletérios (Vigarello, 1985). Antes, o grande desinfetante era o fogo-maneira de impedir a circulação de ares e de águas. Agora, nos novíssimos tempos, já se principia a acreditar nas virtudes purificadoras da água e já se considera bem a idéia de lavar. Porém, até o final do século XVIII e durante boa parte do XIX, 'limpar' foi fundamentalmente drenar, retirar água (Corbin, 1987). O medo da água que remanesce está certamente na origem de nossos banheiros contemporâneos, com seus pisos, paredes e objetos envernizados, esmaltados, enladrilhados e porcelanizados - lugares projetados para serem enxutos muito facilmente, se (coisa que se deve evitar) eventualmente molhados.

Nunca será demasiado insistente relembrar, até mesmo pela atualidade da questão, que as populações não foram convencidas automática e imediatamente dos princípios dessa nova urbanidade e dessa nova sensibilidade. Não foi de repente que se estabeleceu uma divisão entre o odor dos humildes e o dos ricos, entre o burguês 'desodorizado' e o povo 'infecto'... Foi necessário um grande esforço pedagógico nas grandes cidades - trabalho que continua de modo interminável e permanente - para convencer as pessoas de que as cidades deviam ficar 'limpas' e que isto dependia de que modificassem seus hábitos e mentalidades.

Este trabalho consiste essencialmente em uma doutrinação seriíssima, que começa na primeira educação - com os pais ensinando suas crianças a evitar certos cheiros, determinados contatos e a não jogar restos no chão das vias públicas -, prossegue insistentemente nas escolas e nos meios de comunicação e é reforçada por leis e punições sempre mais detalhadas e sutis. Até 
mesmo uma polícia especial acabou estabelecendo-se em toda cidade de algum porte para vigiar as condições da limpeza urbana, para localizar os que não se deixaram catequizar pela religião da limpeza, para condenar e castigar aqueles que tramarem contra suas disposições. 


\section{8 \\ Indivíduo e Decomposição}

Há outra faceta deste processo de higienização e desodorização que consideramos nas páginas anteriores. Ela coloca em evidência o indivíduo, a pessoa, acionando um conjunto de crenças, de sentimentos e de práticas a que habitualmente damos o nome de asseio ou higiene pessoal. Ao lado do grande projeto de 'desinfetar' as cidades, a higiene pessoal explicita o sonho extremo de tudo limpar. Tudo: das ruas às casas, dos quartos aos corpos, dos corpos aos poros. Trata-se de uma ambição grandiosa, complexa, totalizadora, destinada a se desdobrar ao longo de um período extenso, durante o qual, a despeito de variações importantes, a estrutura das emoções, da sensibilidade e do comportamento das pessoas vai mudar de maneira radical em direção a metas bem claras e específicas. Neste e nos próximos capítulos, dedicaremos nossas atenções fundamentalmente a estes problemas.

É preciso registrar, para início de raciocínio, que um dos domínios que se autonomizaram com relação ao amálgama que formava o universo medieval foi exatamente este a que cotidianamente nos referimos como 'indivíduo'. De um modo geral, não é muito fácil convencer as pessoas de que a idéia que vem à nossa mente, quando falamos de indivíduo, não tenha existido sempre em concretude, de que não seja absoluta ou eterna, de que o conceito a que se refere tenha uma história. Não seria ousado demais afirmar que esta talvez seja uma das maiores dificuldades que os antropólogos encontram para se entenderem com seus auditórios: mostrar a indivíduos que suas idéias e sentimentos individuais não são assim tão individuais e que representam respostas a determinadas condições sociais e históricas.

Semelhante dificuldade é perfeitamente compreensível: afinal de contas, com que sistema de pensamento eu penso, senão com aquele que está introjetado em minha individualidade e que me constitui? Com que sensibilidade sinto, senão com aquela que me faz exatamente como sou? Não obstante, é absolutamente fundamental termos em mente que este indivíduo é uma instituição. Que ele não existiu desde sempre. Que não é universal nem absoluto. Sem este esforço, não poderemos olhar para a nossa cultura, não atingiremos o entendimento dos processos de sua formação. Não conseguiremos nos livrar dos óculos que tingem o mundo com uma única coloração. 
Podemos tomar o suceder das sepulturas como exemplo ilustrativo desta história da individualidade. Das fossas coletivas medievais, aos jazigos individuais modernos e às tumbas que podemos ver nos cemitérios militares norte-americanos de hoje em dia - com suas multidões de cruzes brancas, idênticas e individuais, com sua característica pobreza semiológica, para não falar das míseras caixinhas em que se guardam os restos dos crematórios, prestes a serem dissipados ao vento - as sepulturas materializaram uma história de mais de mil anos, durante a qual a noção de indivíduo veio gradativamente sendo elaborada, por meio de sucessivas separações de corpos, corpos que cada vez mais representam seres humanos individuais. As várias etapas dessa história evidenciam concepções diferentes do que seja individualidade, desenhando, no fluir do tempo, circunferências de diâmetros cada vez menores, territórios mais e mais circunscritos, que se separam e se distanciam incessantemente.

A concepção de morte prevalente na Idade Média era a de que esta é um sono. Os mortos dormem, aguardando o dia do Grande Despertar, quando todos sairão jubilosamente, de corpo e alma, das suas sepulturas - tendo dormido mil anos como se esses tivessem sido apenas uma noite. Era um tempo, para relembrar algo já comentado em capítulo anterior, em que reinava com fervor o credo na ressurreição da carne, tempo em que todos depositavam esperanças no glorioso ressurgir.

Este ressurgir seria coletivo, como tudo, aliás, na vida medieval. Todos, juntos, com aspecto sereno e jovial, deixariam lentamente os seus túmulos, espreguiçando-se do repouso, para continuar a vida na corte celeste, para viver ainda mais próximo de Deus, dos evangelistas, dos santos e dos anjos, comungando da vida celestial em uma comunidade sem fim (Duby, 1988b). A espera por este despertar era tranqüila, pois nos tempos medievais acreditava-se que quase todos iriam para o céu, excetuando-se talvez uma minoria, formada por hereges, sacrílegos, regicidas, suicidas, traidores etc. Em geral, a morte medieval era vista como democrática, reduzindo tudo ao denominador comum. Reis, nobres, camponeses: todos, no final das contas, acabariam atingidos por essa foice, que corta rasteiro e por igual.

O cristão medieval era alguém que já estava no céu, quase por definição. A vida eterna estava conquistada praticamente desde sempre. Assim como todos os vizinhos se sentiam ultrajados quando um aldeão cometia algum crime, da mesma forma todos pensavam poder ser salvos pela pureza e pela abstinência de uns poucos representantes - os monges. Deste modo, alguns poucos homens estavam encarregados de aplacar a cólera do céu, por instrumento de gestos, orações e fórmulas. Era deles a tarefa de capturar o perdão divino, espalhando seus efeitos benéficos em torno de si e sobre todos. O batismo nesses tempos representava um verdadeiro passaporte para a salvação: bastava ter recebido o sacramento e não ter cometido graves faltas depois; bastava não ter sido excomungado; bastava 
ter feito as suas páscoas, as comunhões; bastava não haver praticado heresias. Tudo isso, mesmo assim, dentro daqueles parâmetros assaz flexíveis, que sabemos terem sido os da Igreja na Idade Média.

Um exemplo dessa flexibilidade, entre tantos já mencionados, era o fato de que até no caso das execuções capitais fosse comum o carrasco pedir perdão ao condenado. Ao mesmo tempo, havia grande polêmica sobre se seria legítimo recusar confissão e extrema-unção ao criminoso condenado à morte, uma vez que tal negativa significaria certamente de sua condenação eterna. A idéia básica era que esta última configurasse uma punição exagerada, da qual um cristão devesse estar isento quase que por princípio. De modo coerente com essas inquietações, no século XI o Concílio de Viena recomendou que fosse ministrada ao menos a penitência e, no século XIII, o oferecimento deste sacramento aos condenados à pena capital acabou tornando-se obrigatório.

O cristão medieval era, pois, alguém que ressurgiria gloriosamente. Por essa razão, não havia grandes preocupações, importantes tensões, com relação à morte. Morrer não era algo muito além do que já fosse familiar, do que já fosse cotidiano, pois morria-se muito naqueles tempos. Ninguém, no contexto medieval, precisava preparar-se para a morte, uma vez que não é comum alguém preparar-se para algo com que já esteja familiarizado. Morrer e viver não eram coisas assim tão distintas. A morte não era ruptura com a vida. $O$ cadáver não se opunha ao corpo vivo. Morrer não tinha apenas o lado fúnebre que viemos a conhecer, pois era também alegre e democrático. Possuía alguma coisa de festivo, era um espelho realista do que iria acontecer a todos. A cultura popular de certa forma ironizava a morte, sobretudo quando esta abatia os potentados que arrogantemente se acreditavam superiores - um traço, aliás, que permanece muito fortemente presente nisso que tenho chamado de subsolo de nossa cultura contemporânea.

A imagem medieval da morte persiste, de certa forma, em nossos tempos. É claro que hoje nossas teologias e nossa visão cientificista do mundo não permitem mais, em geral, que acreditemos na ressurreição da carne. No entanto, se considerarmos nossos bastidores culturais, veremos que de algum modo permanece, ainda não tendo sido de todo banida, a idéia de que a morte seja um sono e de que as pessoas se devam reencontrar no além. É claro também que esta noção não continuou com a mesma intensidade que possuía nos tempos medievais, e que em vários segmentos da sociedade já desapareceu quase completamente. Em outros, no entanto, o corpo, mesmo defunto, prossegue tendo uma positividade que faz ainda crer que alguma coisa nele seja indestrutível. É até bastante possível que neste ponto resida a dificuldade crucial de muitos em aceitar os argumentos racionais que procuram convencer-nos a respeito dos 'melhoramentos' técnicos ou sanitários representados pela cremação, bem como em acolher os 'avanços' reivindicados pelos defensores da doação de órgãos - 
resistências que sabemos encontrar-se em vários países, assim como em diversos estratos sociais contemporâneos, particularmente naqueles que preservaram a tradição católica de maneira mais intensa.

Os textos que falam da morte na Idade Média, conforme nos ensinou Philippe Ariès (1977), quase sempre começam mais ou menos assim: "fulano de tal, sentindo a morte próxima...". Quase invariavelmente, independendo do que se narre em seguida, o relato desemboca em recolher-se a pessoa ao leito, porque é no leito que se morre, assim como é no leito que se dorme. A cerimônia de morrer é um acontecimento público, como público é tudo na Idade Média. A morte padrãocultural é a daquela pessoa que, sentindo que vai morrer, providencia ser envolvida por seus amigos, seus parentes, seus vizinhos, seus animais, sua casa, e preside a cerimônia de sua despedida (Febvre, 1947).

O moribundo ouvia os participantes e conduzia o ritual de seu próprio falecimento. Acertava suas contas, pagava dívidas, fazia testamento ainda oral e confissão ainda pública, dava conselhos, pedia desculpas... De alguma forma, aquele que ia morrer, com a autoridade dos que não precisam mais barganhar com a vida, promovia a confraternização dos presentes e transmitia todas as riquezas que possuísse, das quais não se considerava na verdade senão um depositário provisório. Tudo era visível, e o que eventualmente estivesse oculto deveria ser solenemente revelado nesta ocasião. Temia-se justamente a morte sorrateira, de que não se conhecessem os detalhes; causava medo a morte repentina, sem cerimonial; trazia pânico a morte acidental, que comparecia sem se fazer anunciar. Semelhantes fatalidades continham, acima de tudo, o amargo sabor da ruptura.

O moribundo tinha um papel a desempenhar, papel que exigia dele uma grande dose de consciência de que fosse morrer. Exigia também, com muita probabilidade, uma certa vontade de partir. A medicina da época conhecia alguns recursos para permitir que isso acontecesse, mas o médico (ou seu equivalente) não lutava contra a doença ou contra a morte. Não se pensava em absoluto que a função do médico pudesse ser a de salvar a vida ou de prolongá-la. Ao contrário, jamais se imaginaria no contexto medieval que o médico devesse se contrapor aos desígnios divinos e interferir no fluxo espontâneo do viver e do morrer. Seu papel era apenas transformar essa cerimônia em coisa factível, mantendo a dor mais ou menos sob controle, possibilitando uma certa consciência, lucidez e bastante serenidade à pessoa que partia, com o fito de permitir, tanto quanto possível, que a cerimônia de morrer pudesse ter lugar.

Além disso, nesse momento medieval, a cena da morte era quase totalmente leiga: acontecia sem interferência de outro poder que não o da comunidade imediata formada pelos familiares, pelos próximos, pelos vizinhos que acudiam, pelos passantes e mesmo pelos animais, que ali também compareciam e que acompanhavam os homens na morte do mesmo modo como o haviam feito durante a vida. Essa cena de morrer não era uma cena eminentemente religiosa, na medida 
em que se possa afirmar essa qualidade de algo da Idade Média. Comparativamente, a morte medieval era uma morte leiga: não era ainda a que seria no século XVIII, predominantemente dominada pelo padre e pela Igreja; nem era, muito menos, a que viemos a conhecer em nossos hospitais contemporâneos, apropriada pela administração hospitalar e pela medicina.

Outro poder não interferia, mesmo quando se tratasse da morte de um religioso. Eis, por exemplo, como Georges Duby descreve uma dessas cenas, desenrolada no mosteiro de Cluny entre os séculos XI e XII, um caso ilustrativo do panorama geral, e no qual, em âmbito específico, o domínio religioso comparece como sinônimo de comunitário:

\begin{abstract}
para a maioria, a estada na enfermaria antecedia a entrada no outro mundo e esta passagem era também cerimônia ritual e coletiva. Ninguém morria só. O trespasse era um ato menos privado que quase todos os outros. Em torno do agonizante, como na sociedade profana para as bodas, organizava-se uma espécie de festa onde o convivio atingia sua plenitude. Levado por dois de seus irmãos, o doente, quando o seu estado se agravava, era retirado da enfermaria, conduzido para o meio da assembléia, na sala de reunião dita capitular, para sua última confissão, que deveria ser pública. Em seguida o moribundo voltava à enfermaria para receber a comunhão, a extrema-unção, e despedir-se da comunidade; após ter beijado a cruz, ele trocava o beijo de paz com todos os seus irmãos, começando pelo padre-abade, como fizera no fim de seu noviciado. Desde o começo da agonia ele era velado sem descanso; colocavam-se diante dele cruzes, círios, e todos os monges, advertidos por batidas à porta do claustro, reuniam-se e recitavam no lugar de seu irmão o Credo, as litanias. Quando ele havia entregue a alma, seu corpo era lavado por outros monges, seus iguais na hierarquia das idades e dos oficios (...). (Duby, 1991c:65-66)
\end{abstract}

No entanto, lentamente, foram aparecendo concepções sobre o fim da vida e sobre a vida eterna que tendiam a apagar essa representação tranqüila da cena de morrer. Não é mais o Grande Despertar que vai florescer; não resplandecerá mais o ressurgir comunitário, pelo qual todos juntos se ergueriam gloriosamente de seus túmulos. Começa a haver uma grande excitação de novas idéias sobre a finitude humana e sobre o sentido da eternidade, concepções que irão exibir intensa afinidade com nascentes teorias sobre o valor crescente da vida terrena. Tais elucubrações, no início bastante tímidas, progressivamente se fortalecerão, de modo especial junto às camadas superiores. Sem se limitar a estas, todavia, pois no correr dos séculos estas elaborações conquistarão cada vez mais adeptos também em outros estratos sociais. Como conseqüência, as práticas associadas ao novo modo de pensar irão aos poucos e poucos e sutilmente se impondo como obrigatórias. 
A noção de inferno começou a adquirir especial importância por volta do século XIV, passando a figurar de maneira mais e mais ostensiva nos sermões, nas paredes das igrejas, na vida cotidiana, nos jogos de poder. O inferno se mostrava como instância repressiva ambígua e ambivalente: um pouco, expressão de um novo mundo social e político; um pouco, instrumento de dominação dentro da visão antiga, como um controlador dos excessos daqueles que, por esquecerem de que ainda pertenciam a uma comunidade, exageravam na autonomia de si. Brandida por toda parte, a imagem do inferno mostrava fundamentalmente decomposição e sofrimento (Delumeau, 1978). Com o fortalecimento do papel do inferno, o batismo já não era mais automaticamente um sinônimo tranquilizador de vida eterna e de entrada no céu. Ser cristão já não significava garantia de salvação, nem de gozo comunitário das delícias celestiais.

Algumas imagens sintetizaram os novos modos de se verem as coisas relativas ao destino humano (Ariès, 1975). Uma dessas imagens era a balança, em que se punham, em um prato, as boas ações e, no outro, os atos ruins que alguém eventualmente tivesse praticado: o prato que mais pesasse encaminharia seu responsável para o céu ou para o inferno. A pessoa será pesada individualmente, no fim da sua vida particular, no último instante de sua existência terrena, no quarto em que vier a falecer, na hora exata em que estiver morrendo. Sua vida individual será submetida a um verdadeiro 'balanço', para usar a linguagem dos novos tempos. Uma segunda imagem - que, aliás, permanece até hoje sobre muitas sepulturas contemporâneas - é a de um livro. Trata-se do liber vitae, aquele que insinua que a existência de cada um seria mais ou menos como um texto que se escreve linha por linha. Nada está jogado: pode-se construir a vida a cada página, mas também é possível pôr tudo a perder na última delas, no momento preciso de morrer. A última página não será, pois, a derradeira: decidirá sobre a continuidade e o destino de cada um na vida eterna - céu ou inferno? Enfim, temos a imagem da cena de morrer como a de um dramático tribunal, em que Deus é representado como o Grande Juiz, deslocando o Julgamento Final, que deveria ter lugar no Fim dos Tempos, para o final de cada vida individual: de um lado do leito do moribundo, os anjos bons, a corte celeste; do outro, os demônios, os anjos maus. Disputam entre si o destino daquele que se vai. Daquele que se vai, doravante sozinho.

Essas imagens, às quais se poderiam adicionar as de anciãos carregando ampulhetas, as de megeras com asas de morcego, as de esqueletos armados com foices (Delumeau, 1965), sintetizam caminhos por meio dos quais, de uma cerimônia coletiva e pública, o último momento começa a adquirir as cores de um drama individual e íntimo - porque, afinal, ninguém tem mais certeza do que poderá acontecer nessa hora tão decisiva. Nesse instante crucial, alguém poderá salvar-se? Ter tido uma vida dissoluta, pecaminosa, e arrepender-se? Poderá, contrariamente, ter vivido uma existência virtuosa, mas nos últimos suspiros se prender demasiado às coisas terrenas e tudo deixar escapar? 
Compreende-se, assim, que, no plano das sensibilidades, com essas novas imagens, a antiga tranqüilidade comece a ceder e que principie a aparecer um sentimento de medo diante da morte. Sobretudo, entende-se que emerja um especial sentimento de angústia em frente da perspectiva de morrer. A morte, por conseguinte, torna-se um evento singular, que precisa ser preparado. Por esta razão, passa a ser necessário, dali em diante, passar a vida pensando nela. Passa-se a pensar na morte exatamente porque se a teme. Eis como ela começa a envenenar a vida.

Tudo isso tem a ver com o fato de que, a partir de agora e cada vez mais, cada um será pensado como dono da própria vida, como proprietário de uma biografia individual. No imaginário fundado pelo capitalismo, cada ser humano torna-se uma espécie de proprietário privado de si mesmo e de sua biografia: é ele quem decide seu destino; é ele quem pode tudo salvar ou tudo pôr a perder; é ele, enfim, que pode fazer ou desfazer a sua vida. Claro que essas crenças configuram uma fantástica ilusão. Mas não podemos esquecer que é exatamente sobre essa ilusão de propriedade de si, de posse do próprio corpo e da própria vida que o capitalismo se funda. A propriedade privada de si constitui o mito de fundação do capitalismo. Cada um, dono de si. De sua iniciativa. Proprietário particular de sua vida. De seu corpo. Cada um pode alugar sua força de trabalho. Vendê-la no mercado. Ter interesses privados. Em contrapartida, cada ser humano tornase responsável por si.

Duplo medo, por vias de conseqüência. Dupla angústia: uma, relacionada ao destino da alma, ao que acontecerá consigo depois desse momento definitivo que é a hora da morte, depois do julgamento, depois da pesagem, depois de virada a última página do livro; outra, relativa ao que ocorrerá com o corpo, com esse suporte que materializava a individualidade de si e que entrará agora em decomposição. Essas angústias preparavam existencialmente, de modo lento, o momento em que se inventará, formalmente e de modo teórico, a separação entre o corpo e a alma. Na prática, dupla estratégia existencial: por um lado, a alma, inextinguível, continuará vivendo no além - bem ou mal - para preservar a individualidade do morto; por outro, o corpo, finito no tempo, prosseguirá existindo, sobre-existindo, ou mesmo sub-existindo no espaço, isto é, no lugar simbólico representado pela sepultura individual.

Relembremos rapidamente que os cemitérios medievais não apenas se situavam dentro das cidades, como também se localizavam dentro das igrejas, centro da vida comunitária (Ariès, 1975). Junto com a igreja, o cemitério era simultaneamente o lugar das proclamações, das diversões, das festas, o templo se constituindo em um dos espaços mais movimentados da cidade. Sabemos que uns dos referenciais básicos da religião cristã eram as sepulturas de mártires ou de santos, sobre as quais com freqüência se erigiam os lugares de culto. 
Todos queriam ser enterrados perto de um santo, na proximidade de um mártir fundador. Daí todos desejarem ser sepultados dentro de uma igreja. Existia mesmo uma acirrada competição, em que os poderosos evidentemente sempre levavam a melhor, no sentido de conseguirem ser inumados o mais próximo possível das relíquias ou do corpo do mártir. Obviamente, o povo comum acabava não sendo enterrado dentro da igreja, mas ao lado dela, uma vez que pelo menos uma das paredes do templo pertencia também ao cemitério.

De um modo geral, apesar da oposição formal que a Igreja sempre levantou contra esta prática, os poderosos acabavam por obter sucesso em serem enterrados dentro dos templos. O enterro ad sanctos representava muitíssimo para a cosmovisão medieval e constituía um privilégio de que dificilmente alguém poderia abrir mão de bom grado. Assim, os membros das elites o retiveram, e com isto também marcaram em definitivo os signos de sua ascendência social. Exatamente eles, que vieram a proibir para os outros o enterramento dentro das igrejas, continuaram até hoje sendo inumados no interior dos templos - exemplo significativo são os próprios papas, que continuaram sendo sepultados, até nossos dias, dentro de uma igreja, na Basílica do Vaticano, embaixo do altar principal, bem próximo, como se acredita, do túmulo de São Pedro.

As sepulturas medievais em geral eram coletivas e ficavam entreabertas até serem preenchidas. Uma característica fundamental dos túmulos na Idade Média é que não eram concebidos como um domicílio pessoal, nem como uma espécie de propriedade privada que o defunto detivesse até a eternidade, idéias modernas que não existiam naquele tempo. Somente depois do século XII é que começaram a aparecer tumbas que insinuavam possuir tais qualidades. Na verdade, no passado, e principalmente hoje em dia, isso que costumamos chamar de jazigo perpétuo tem esta característica apenas no imaginário, porque, de fato ou de direito, são quase sempre concessões com prazo determinado. Mas esse imaginário não é absolutamente gratuito, pois a ilusão que contém expressa de modo bastante realista os efetivos sentimentos que passarão a vigorar.

O cenário comunitário do cemitério medieval começa a ser abalado pela manifestação de pequenos processos, pequenas práticas, tímidas no princípio, que indicavam mudanças nas mentalidade e nas sensibilidades. O principal procedimento prático e concreto a indicar esse movimento foi o aparecimento, ou melhor, o reaparecimento dos túmulos individuais. O surgimento do túmulo individual insinuava que as pessoas principiavam a aspirar a uma sobrevivência ou a uma permanência não apenas na vida eterna e etérea, não apenas no céu: o fato de que alguém quisesse marcar a sua passagem individual pela Terra, pelo reino dos temporalia, fixando-a com um monumento, sugere uma certa vontade de permanência concreta e material no aqui.

De fato, ainda exibindo um toque da cor dos tempos, as primeiras sepulturas individuais são jazigos que os mortos partilham com seus familiares. Não são ainda cem por cento individuais, e, em grande medida, continuarão a não o ser em 
boa parte do Ocidente, de acordo com as épocas e com os segmentos sociais. Algumas dessas primeiras sepulturas surgiram como pequenos tetos, sugerindo que o túmulo fosse análogo a uma habitação, moradia, lugar onde se reside com familiares. Mas esses tetos continham, ao mesmo tempo, as idéias de proteção e de conservação do corpo: tentavam impedir que houvesse infiltrações de água, pateticamente arvorando que um pouco do corpo se conservasse e que valesse a pena lutar contra a tanatomorfose.

Outras sepulturas iriam ser encimadas pela representação estatuária de um morto que dorme, deitado sobre a sepultura em que jaz, projetando na pedra a concepção medieval de que a morte fosse um sono. Com freqüência, a estátua representava inequivocamente o próprio morto, pois não raro era uma máscara bastante realista que tinha sido moldada diretamente sobre o rosto do moribundo, no momento mesmo da morte, como se visasse a marcar o instante exato da passagem de um mundo a outro.

Um detalhe, contudo, é extraordinariamente significativo: o drapeado das vestes dessas estátuas era normalmente horizontal, paralelo à sepultura, desafiando a lei da gravidade e deixando sutilmente perceber que, embora deitado, aquele ser aspira à verticalidade e quer despertar. Cedo, esse morto-que-dorme seria um morto-que-age, pois começariam a aparecer estátuas de pessoas ajoelhadas, rezando, lendo, praticando gestos de vivo, ao mesmo tempo em que os rostos dos mortos, por evocarem demasiado fortemente a morte, tenderiam a desaparecer dos ritos funerários e, de modo semelhante, da estatuária fúnebre.

O túmulo não é um lugar qualquer. Aos poucos se transforma em um jorrar vulcânico de desejos. Não constitui simplesmente um buraco pertencente a alguém, individual ou familiar. A sepultura representa também um monumento, uma peça semiótica que contém uma tática comunicacional. Assemelha-se muitíssimo a um daqueles espaços que o historiador Pierre Nora chamou de "lugares de memória", lugares que "nascem e vivem do sentimento de que já não existe uma memória espontânea, de que é preciso criar arquivos, de que é preciso manter aniversários, organizar celebrações, pronunciar elogios fúnebres, registrar atas, porque essas operações não são naturais" (Nora, 1984: XXIV).

Antes de tudo, as sepulturas individuais pretendem proclamar para os vivos as virtudes imperecíveis dos habitantes que abrigam. No início, suas mensagens são pequenas frases. Aos poucos, entretanto, estas se vão transformando em verdadeiras biografias que, com todos os exageros do desespero, narram os feitos e, sobretudo, os haveres desses que agora têm sede própria, desses que doravante são proprietários privados de uma sepultura, embora temam pateticamente a crueldade do esquecimento.

Seguindo uma tendência histórica geral no sentido da miniaturização das coisas - bastante compatível, aliás, com o espírito do capitalismo -, as obras artísticas têm suas dimensões reduzidas. Tornam-se objetos passíveis 
de apropriação individual, capazes de serem tidos entre as mãos, possuíveis, por assim dizer, destinados a serem propiciadores de deleites pessoais e privados (Duby, 1988b). A obra de arte maior do século XIV, coerentemente, não consistia mais na catedral, nem no palácio: era o túmulo. Apenas alcançavam alguma riqueza, preocupavam-se as famílias em subtrair os seus à vala comum. Assim, entre os séculos XV e XVII, gradualmente, o indivíduo e sobretudo as famílias se foram apropriando do lugar de enterro, da sepultura e do monumento que se construía em cima destes. Procuravam ir privatizando o terreno mortuário mediante o uso de possessivos, antes dispensáveis e até mesmo incogitáveis: "jazigo perpétuo da família de...", "construí esse túmulo para o meu corpo, para o de minha mulher e para os dos meus"...

Essas sepulturas eram como cofres a acumular corpos individuais, a entesourar os patrimônios cadavéricos das famílias - e isto a tal ponto, que os ricos muitas vezes construiriam igrejas ou capelas especialmente para nelas possuírem suas próprias sepulturas. Os grandes comerciantes, as grandes famílias, começariam em alguns casos a inverter as coisas. Em vez de serem enterrados na instância coletiva, isto é, na igreja comunal, desejariam freqüentemente empreender a construção de suas próprias igrejas privadas, para nelas poderem possuir sepulturas para si e para os seus. "Os reis já não são os únicos que no século XIV constroem suas santas capelas" (Duby, 1979:227).

Os sepulcros privados começaram a existir primeiro dentro, depois nas adjacências das igrejas, e por fim em lugares especialmente destinados a finalidades cemiteriais. Uma verdadeira efervescência de túmulos individuais-familiares teve lugar, quase sempre proclamando as glórias imorredouras de seus habitantes. Este é um ponto importante a colocar em evidência, como indicador de mudança, pois a procura da glória individual foi um atributo característico dos homens que viveram a partir do Renascimento - a Idade Média conhecia a honra e a glória apenas sob forma coletiva, como honra e glória de grupos. Nenhum mortal brilhava com sua própria luz (Dalarun, 1990; Huizinga, 1978).

Síntese desse processo: a multiplicação dos túmulos individuais de início contemplou, é óbvio, os poderosos, nobres e clérigos; em seguida, os burgueses; depois, os pequenos burgueses; finalmente, os proletários, operários e camponeses. Todos passaram lentamente a ter, não apenas a vontade, mas, ao menos em teoria, o direito a uma sepultura individual.

Seja a mais simples das covas rasas, no final desse processo o mais indigente dos seres humanos no Ocidente passou a merecer, no mínimo teoricamente, o direito a uma sepultura individual (exceto, talvez, em condições de cataclisma social). No início, a propriedade de uma sepulcro privado era um privilégio, que muito lentamente se foi democratizando. Mas é preciso não esquecermos de observar que essa democratização significou também a transformação do sepultamento individual em obrigação, a ponto de se chegar ao momento em que não se 
conceberia mais, não passaria mais pela cabeça de ninguém que as coisas poderiam não se dar desse modo. Direito e/ou obrigação a uma sepultura particular - mesmo que na forma de humilde gavetinha para alojar as cinzas mal identificadas de um cremado.

Com o tempo, também são privatizados os destinatários das mensagens do monumento funerário. Reduzem-se quase unicamente aos familiares as pessoas que passam a cultuar o túmulo individual ou particular. Do ponto de vista sentimental, coerente e reciprocamente, a sepultura privada interessa doravante apenas àqueles que tivessem tido algo a ver com o(s) morto(s) específico(s) que a ocupa $(m)$. Não se trata mais da sepultura comunal da Idade Média, que tocava à afetividade de todos. O sepulcro tornou-se crescentemente um jazigo particular, que só diz respeito a uns poucos. Por isso, os outros homens acabam passando com relativa indiferença ao seu lado, às vezes mesmo pisando em cima. Ao menos no plano dos afetos, as mensagens que esses monumentos transmitem passam a ser discurso situado entre o inaudível e o silencioso.

Não obstante, essas sepulturas transmitem também, para todos e para cada um, uma espécie de recusa privada e coletiva da morte. E o fazem de modo cada vez mais ruidoso. Elas são habitadas por alguém que ainda desejava viver, quer porque tem nome e endereço individuais, quer porque pratique gestos de alguém desperto, quer porque envie patéticas mensagens por meio de seus epitáfios... Mais tarde, assim que as técnicas o permitirem, virão as fotografias do morto sobre o local de inumação, retratos que não serão mais as antigas máscaras realistas moldadas sobre o rosto do cadáver, mas imagens dele quando jovem, do defunto quando saudável. Tais adornos sepulcrais indicam insistentemente que os habitantes dali não se sentem plenamente em casa, que não mais dormem tranqüilamente e que o epitáfiosíntese poderia perfeitamente ser: "aqui jaz fulano de tal, muito contra a vontade".

Essa recusa da morte faz bastante sentido nos quadros específicos dos novos modos de vida em que emerge. As práticas e crenças funerárias que estou relembrando apontam para um decidido movimento na direção da individualização, configurando transformações muito lentas, mas perfeitamente compatíveis com o sistema econômico que ao mesmo tempo se está constituindo e se desenvolvendo com base nas noções de iniciativa particular, de propriedade privada, de acumulação, de progresso... Nesse sistema, ninguém se conforma com a brevidade da vida, pois viver representa um meio de capitalizar. E viver muito, em uma sociedade baseada na rentabilidade do tempo, um meio de acumular e enriquecer.

A fatalidade tradicional em relação à morte começa, assim, a ser enfrentada de modo cada vez mais sério e obstinado, resultando, em meados do século XVIII, em precauções novas, relativas sobretudo ao cuidado das crianças, ao saneamento das habitações e das cidades, à higiene pessoal, ao cuidado de si e às preocupações com a saúde e com o prolongamento da vida. Crescentemente os homens passam a ser considerados como verdadeira riqueza dos Estados, como máquinas preciosas, desenvolvendo-se uma atenção particular relativamente ao homem como trabalha- 
dor individual e como força coletiva de trabalho, cuja duração - ao contrário do que se pensa comumente - não deve ser maximizada, mas optimizada (Attali, 1979). Acontece, entretanto, que esses pilares dos novos modos de vida serão direta e radicalmente desafiados pela morte. E este desafio significará o nascimento de terríveis infernos interiores.

Compreende-se. A morte, pelo que tem de decomposição, invoca de maneira radical o desaparecimento da individualidade (Morin, 1970). É um alarido silencioso, um anunciador da individualidade que se dissolve, que se vai perdendo, esvaindo-se da concretude das coisas, evaporando-se das memórias, volatilizandose no esquecimento... Para uma sociedade que acredita na individualidade e a cultua, a morte é blasfema, heresia cruel a mostrar ser o indivíduo um terreno movediço, no qual é vão e filosoficamente equivocado buscar alguma solidez para edificar a vida. Esta vida que agora é "o oposto da morte", conforme a definição que lhe deu a Enciclopédie, ou é "o conjunto das funções que se opõem à morte", consoante a concepção de Bichat, logo na primeira página de suas Recherches Physiologiques sur la Vie et la Mort...

Uma vez que significa exatamente a diluição do indivíduo na espécie, a morte é a contrapartida lógica da idéia de indivíduo, da qual representa simultaneamente a fundação e o fim (Foucault, 1978). A rigor, a morte acaba existindo somente para quem gosta de conceber como individual a essência mais importante de si. De certo modo, como já vimos, ela não existia nos tempos medievais, pois que os mortos estavam ali perto, convivendo com os vivos, dormindo. A morte não precisava ser recusada, simplesmente porque ainda não se havia afirmado, simplesmente porque ainda não havia sido inventada como a negação da vida. Era considerada, para lembrar as palavras de Bakhtin, "uma entidade da vida, na qualidade de fase necessária, de condição para sua renovação e rejuvenescimento permanentes" (1987:43).

Nos quadros de uma sociedade que se erige sobre a idéia de individualidade, compreende-se igualmente que um dos caminhos inventados para materializar o esforço de salvá-la, ao vê-la diluir-se, fosse o de separar o espírito da matéria, proclamando-se, em seguida, que apenas a segunda se decompusesse e que o espírito continuasse para sempre a existir individualmente.

Ocorre, entretanto, que as novas maneiras de dar sentido à existência, além de serem individualistas, são também materialistas o suficiente para não se satisfazerem apenas com a vida eterna do espírito. A própria separação entre espírito e matéria passou a significar um gesto primordial de invenção de algo degradável na integridade humana. Este é o ponto em que o inconformismo começa a sonhar com a vida eterna da matéria, com a vida eterna aqui mesmo na Terra - uma aspiração que, no limite, vai acabar permitindo que alguns viessem a negar até mesmo a imortalidade da alma e que viessem a temer sobretudo a morte aparente e, em conseqüência, a possibilidade de serem enterrados vivos. 
No extremo mais absurdo, esse moderníssimo sonho de vida eterna veio desaguar nas técnicas contemporâneas de prolongamento da vida e, em particular, nos delírios de imortalidade contidos nos procedimentos de congelamento. Tais procedimentos são intervenções mediante as quais se alimenta a ambição de que se poderá voltar a viver no belo dia em que a ciência tiver descoberto os meios de cura das doenças de que se (quase) teria morrido. Esta veleidade ilustra também o limite extremo do individualismo e do culto à matéria, posto que tal delírio sonha apenas com a sobrevivência biológica individual, desprezando qualquer convivência. Interessa apenas 'minha' vida, 'minha' matéria, nada mais que 'minha' vida biológica individual e particular. Perguntas que incidam sobre com quem se viverá na vida pós-degelo - estarão lá meus filhos, meus amigos? - não se formulam em absoluto.

Poderemos compreender a recusa da morte no âmbito dos novos modos de vida se considerarmos que ela é a última coisa em que pode pensar aquele que acredita na acumulação e no progresso. Na sociedade capitalista, aprende-se a viver com base no adiamento do prazer, condição ética e existencial indispensável para a acumulação e o investimento. Acima de tudo, aprende-se que a felicidade é algo que está adiante, alguma situação que se atinge, ponto aonde se chega, alguma coisa que se adquire... Nunca a felicidade é concebida como aquilo que decorre do simples fato de viver, nunca como aquilo que faz pulsarem alegrias e tristezas, nunca como o que impulsiona o ser por seu transbordamento. Absolutamente não: na ética capitalista, a felicidade é essencialmente aquilo que falta, aquilo que se promete somente àqueles que se engajarem em sua conquista. Fingir ter 'conseguido' a felicidade é requisito da negação do fracasso e, por esse caminho, da afirmação de sucesso econômico.

Ora, para a civilização do sorriso profissionalmente artificial, a morte é exatamente o que demonstra que nada disso tem sentido e que todos estes princípios não passam de um amontoado de equívocos existenciais: haverá sempre mais um progresso a realizar quando se morre; morrer é essencialmente aquilo que nos obriga a tudo desacumular; a cova é o que aguarda todos, inclusive aqueles que vivem do adiamento dos prazeres; a prometida felicidade é um logro... O sonho materialista de crescimento e progresso desaba diante do cadáver em decomposição!

Por isso, o burguês, que inventa a morte, não se conforma em ser mortal. Claro: tudo o que ele quer é acumular, progredir e viver esta vida. Não faz sentido morrer. O burguês não quer se acreditar mortal. Inventa, por conseguinte, as duas estratégias básicas que mencionei para, pateticamente, tentar sair da angústia em que ele mesmo se enredou - estratégias que acionará de modo não excludente e que manipulará pragmaticamente, de acordo com suas conveniências. Em primeiro lugar, procurará controlar o futuro através da garantia de vida eterna; simultaneamente, tentará congelar o tempo aqui mesmo, para ter ilusão de perenidade.

Pelo primeiro caminho, o burguês tentará levar uma vida piedosa. Inventará astuciosamente as sociedades anônimas, para que pratiquem, em nome de ninguém, as crueldades que a moral religiosa não perdoaria ao ser humano comum. 
Trilhará, ao menos teoricamente, as rotas do ascetismo. Tentará dar um sentido espiritual à sua existência material... Porém, mesmo após ter separado a economia da moral, não terá mais certeza de salvação, temerá as chamas do inferno e se tornará melancólico. O último momento passará a apavorá-lo durante toda a vida. Angustiar-se-á com o destino de sua alma - e isto virá a favorecer o progressivo triunfo da noção de purgatório, idéia mediante a qual uma espécie de negociação sobre o além se tornará possível, introduzindo o cálculo, o pragmatismo e a barganha nas questões escatológicas (Gourevitch, 1989).

Do mesmo modo, o testamento, totalmente leigo nos tempos medievais, aparece nesse contexto sentimental como um instrumento tático, ao lado da adesão mediante dinheiro a confrarias bem providas de indulgências. Por meio de legados à Igreja, poderia agora o burguês dispor de sua riqueza para 'investir' na vida eterna, encomendando missas - centenas, milhares - pela redenção de sua alma, pela salvação dos que aguardam no purgatório. Ser-lhe-ia possível, desta maneira, comprar a sua instalação confortável no além-túmulo. Tal desprendimento, contudo, seria "menos a expressão do amor desinteressado a Deus e ao próximo que a busca da salvação individual” (Lebrun, 1992:91).

O testamento se transforma, assim, em um documento jurídico, cujo sentido se restringe cada vez mais exclusivamente à transmissão da propriedade. Por isso, passa a ser escrito e obrigatório, sob pena de interdição de sepultura ad sanctos. O testamento representa uma espécie de seguro de vida (eterna) disfarçado, uma vez que a generosidade do testador pode ser um índice de seu arrependimento em relação aos pecados praticados, um atestado de desprendimento quanto às coisas terrenas. Deste modo, consoante o espírito capitalista, a salvação se tornou algo passível de se adquirir comercialmente. Uma imensa cumplicidade se insinua entre religião e economia, na qual a primeira está destinada a ser traída pela segunda. Os passos seguintes dessa história vão resultar na secularização e na descristianização dos testamentos (Vovelle, 1978; Duby, 1979).

Pelo segundo caminho, a burguesia tentará petrificar o fluxo do tempo. Logo ela que, revolucionando as concepções medievais, inventara-o linear, fugaz e irreversível, agora se apavora com o caráter cruel dessa fugacidade que tudo parece devorar. Tentará então fazer seus túmulos com a perenidade das pedras mais resistentes. Marcará o mundo com suas obras. Inventará as biografias e mais tarde as autobiografias. Buscará a permanência das estátuas. Sonhará com a fixidez dos retratos individuais, que começam a ser numerosíssimos a partir do século $\mathrm{XV}$, porque o culto a si acabará superando os antigos temores mágicos relativos à reprodução da imagem pessoal. Refletir-se-á nos auto-retratos. Circunscrever-se-á de espelhos, estes objetos até então raríssimos, principalmente quando dotados de dimensões capazes de capturar um corpo humano inteiro. Especulará sobre a ilusão de ciclicidade temporal permitida pelas fotos e pelos filmes. Criará museus, arquivos, registros... Prolongará a duração da vida indivi- 
dual. Exibirá sua originalidade, mesmo, ou especialmente, se ela for ininteligível para os outros. Acima de tudo, com argumentos baseados no asseio e na higiene, procurará banir toda manifestação de apodrecimento. Apagará qualquer evidência de transcurso do tempo biológico. E, na impossibilidade de se pensar mortal, o burguês cessaria gradativamente de pensar e de falar na morte. Postular-se-á, implicitamente, amortal.

Também não falará dos que morreram, só voltando a fazê-lo, embora raramente, após ter esquecido de que eles se foram. Na sociedade talvez mais mortífera que a humanidade já produziu, o burguês criará paradoxalmente silêncios e tabus sobre a morte. Existirá como se a morte não existisse. Viverá sem consciência de seus limites. Terá, por conseguinte, pouca noção de si mesmo, por mais paradoxal que isto possa parecer. Tratará de si como se fosse um ser amortal. Cada um fará de conta que é feliz porque isso será sinônimo de ser bem-sucedido. Transformará a gravidade da doença em segredo comercial, guardado a muitas chaves. Moribundo, fingirá que não vai morrer. Muitas vezes nem saberá disso. Acabará escondido em um hospital. Seu médico usará todos os disfarces. Aplicará todos os recursos técnicos para dar a ilusão de que ele continuará vivendo. Morto, encontrará sepultura em jardins que cada vez menos se parecem com cemitérios. E todo seu entourage participará da farsa...

Esta ilusão de amortalidade se manifesta de modo talvez mais inequívoco na tanatopráxis de algumas casas funerárias norte-americanas. Refiro-me a ritos fúnebres - ainda longe de serem dominantes, embora não tão raros - que encenam uma espécie de velório. Contudo, são também uma espécie de festa, um coquetel, um vernissage, em que as pessoas se encontram em torno do morto para uma patética cerimônia de culto à personalidade individual. Nessas ocasiões, há uma regra fundamental: a palavra morte está rigorosamente proibida, assim como tudo que a ela esteja associado. $O$ defunto aparece como vivo, maquiado, fazendo algum gesto - lendo um jornal, assinando um cheque, sentado na poltrona, em pé e apoiado em uma escrivaninha de trabalho... As pessoas se despedem dele. Trata-se de uma festa de despedida. Mas de uma despedida de quem não partiu.

O patético disso tudo é que esse vivo-quase-morto na verdade é um mortoquase-vivo: tenta falar ao telefone, mas não consegue; finge que assina um cheque, mas não o faz; abre ostensivamente as folhas de um jornal, mas não as lê... Os participantes vão embora, levando dele a imagem de alguém vivo, e não a de um defunto - e isto para mais facilmente poderem desprezar o fato de que uma morte aconteceu. Nas versões mais leves, temos os drive-thru funerals, estabelecimentos nos quais - na época do fast food, da fast spirituality e do fast sex - é possível assinar o livro de condolências sem sair do automóvel, certamente para olvidar bem rápido, antes do próximo compromisso agendado. Quanto ao morto, é possível que vá confortavelmente habitar uma dessas moderníssimas sepulturas equipadas com bateria solar, em que, como diz o anúncio, poderá "escutar sempre" as suas músicas prediletas. 
Eis o ponto em que acaba por desaguar esse processo que começou nas primeiras sepulturas individuais do século XII: quase mil anos de história, certamente ainda inacabada. À medida que se estabelece no poder, a burguesia vai impondo também aos outros as suas angústias de morte, que são, sobretudo e fundamentalmente, modos de vida. Com o decorrer dos séculos, não será somente da burguesia o privilégio desses sofrimentos. Seguindo os passos e as aspirações das elites, logo será a vez de os pequenos burgueses terem os seus fantasmas, suscitados pela angústia da morte. E chegará também o tempo dos proletários, operários e mesmo camponeses, pois, cada dia mais, estes segmentos se vão embebendo dos novos sonhos, tornando-se cúmplices das concepções de universo e do projeto existencial da sociedade capitalista, industrial e de consumo. Apesar das resistências que sempre demonstraram - sobre as quais nunca será excessivo insistir. 


\section{9}

\section{Alcovas e Corredores}

A separação de corpos e de individualidades que a história ocidental vem exibindo não se refere apenas ao contato entre cadáveres, nem às relações entre estes e os vivos. Não é apenas táctil e não se verifica exclusivamente na morte. Está sobretudo na vida, é também visual, olfativa, gustativa, auditiva... No decorrer desta história, os diferentes sentidos vão gradativamente manifestando-se na delimitação das fronteiras disso a que se poderá chamar 'meu corpo individual'. Este trabalho contínuo de demarcação de territórios individuais está associado às práticas mais concretas do cotidiano e ilustra cristalinamente que existe uma história da apropriação privada do eu, assim como há uma história da propriedade dos bens de produção.

Se quisermos entender as modificações de mentalidades e de sensibilidades que vieram a produzir a espécie de ser humano que hoje constituímos, é estrategicamente interessante seguir a pista que nos oferecem as transformações por que passaram os ambientes imediatos que enquadraram o que havia de mais corriqueiro, cotidiano e significativo das vidas humanas. Refiro-me às habitações, especificamente às suas partes e seus componentes. Nas residências, as sociedades costumam materializar e tornar visíveis estruturas sociais e intelectuais abstratas, de difícil observação alhures. Além disso, normalmente as moradias põem à disposição - para a utilização de seus membros, mas também para o olhar perscrutador do analista - aqueles equipamentos adequados ou necessários à viabilização de um modo particular de existir individual e coletivamente. A casa é, pois, um "locus em que necessidades simbólicas e sociais estão articuladas com necessidades técnicas", para usar as palavras de Pierre Bourdieu (1979:135). A experiência tem mostrado que o estudioso da vida social poucas vezes se arrepende de obedecer às buscas sugeridas por este filão.

Entretanto, esta estrada não deixa de apresentar dificuldades respeitáveis, na medida que pretendamos nos aprofundar no tempo. Na maior parte das vezes, o que permaneceu das casas medievais, sobretudo das menos ricas e imponentes, foi ruína. A arqueologia não exibe muito mais do que restos mortais, que apenas por meio de recursos paralelos (textos, iconografia etc.) podem revelar alguma coisa 
sociologicamente segura. Muito do que era fundamental nos cotidianos nem restos mortais nos legou. Foi o caso, por exemplo, de boa parte das mobílias e instrumentos feitos em madeira, das tapeçarias e dos objetos de decoração feitos de material têxtil ou outros perecíveis - mas os inventários nos falam deles e nos asseguram terem sido razoavelmente numerosos.

Já fiz uma rápida referência ao fato de que as casas medievais apresentavam um aspecto muito mais público e coletivo do que aquelas em que hoje passamos parte considerável de nossas vidas. Fechavam-se menos em si e representavam um corte mais gradual do que qualitativo em relação ao exterior. Abriam-se para campos e ruas, tinham portas e janelas franqueáveis sem grandes cerimônias. Fundamentalmente, a existência no medievo, como vimos, transcorria ao ar livre. As casas da Idade Média não eram lugares de enclausuramento, mesmo em seus interiores. Seus cômodos eram poucos, mas de natureza multifuncional. Seus móveis também não eram numerosos, embora se destinassem à utilização simultânea por muitos (bancos coletivos em vez de cadeiras individuais, por exemplo). E, se a compararmos às casas de hoje, poderemos afirmar com toda tranqüilidade que se destinavam a um número enorme de usuários.

A hospitalidade era uma das características mais espontâneas e evidentes da vivenda medieval. Todo homem que merecesse este título abria as portas de sua casa, convidava à sua mesa e oferecia abrigo sob seu teto (Duby, 1978). Tal traço não era de forma alguma um distintivo de riqueza material, nem um acontecimento restrito aos grandes dias. Não: a hospitalidade era uma regra geral e plenamente cotidiana, que se teatralizava na sala, se houvesse uma, no quarto, com freqüência, ou na cozinha, mais comumente. Até mesmo o eremita era homem de encontros e acolhimento, pois seu abrigo sumário muitas vezes servia de etapa para o viajante desgarrado. Toda a literatura medieval dá testemunho dessa função geral de guarida (Dalarun, 1990). Naqueles tempos ainda não existiam lugares funcionalmente predefinidos para a hospitalidade. Também não havia instantes especificados: com exceção talvez das ocasiões de doença, morte ou festividades, era habitual que os hóspedes chegassem sem avisar, no momento em que bem entendessem e que se demorassem por tempos que certamente nos pareceriam absurdos.

Os visitantes podiam ser os mais diversificados. Em grande parte a população do Ocidente continuava a ser nômade: era o caso principalmente dos chefes reis, nobres, bispos, com os séquitos numerosos que sempre os acompanhavam. Tanto podia um humilde camponês receber em seu casebre um nobre em viagem com sua comitiva, como deveria este abrir suas portas para camponeses, aldeões, magistrados, fidalgos. A hospitalidade era um atributo essencial da nobreza, de forma tal que se observava neste meio social algo bem próximo de uma interpenetração entre o privado e o público, quase osmose. 
Assim, se o castelo ou o solar de um poderoso tendia a parecer uma casa particular, a casa de todo homem que detivesse uma parcela respeitável de poder deveria, por seu turno, tomar o aspecto de um palácio e, em conseqüência, abrir-se para revelar seu interior. Os castelos ou os seus equivalentes constituíam uma espécie de habitat comunitário. Era deste modo que a presença de pobres era considerada indispensável em toda casa abastada e representava, dentro da visão de mundo prevalecente, uma bênção para o senhor e sua família (Duby, 1991b; Mollat, 1989; DaMatta, 1993b). É importante registrar que 'pobre', no contexto do medievo, não significava apenas alguém desprovido de riquezas materiais traduzíveis em cifras monetárias: a categoria incluía também doentes, loucos, anciãos, viúvos...

Ao mesmo tempo, as partes mais públicas da casa senhorial, como as salas, pareciam decididamente preparadas para as festas. Gravuras costumam mostrar os senhores nelas se exibindo com fausto, alimentando amigos e convidados, em mesas destinadas a banquetes. Um simples negociante genovês, um pequeno banqueiro sem muita influência na cidade, por exemplo, gastou em 1460, apenas para o banquete de bodas de sua filha, exatamente um terço do que custou a alimentação do ano para sua casa de dez pessoas. Em Florença, em junho de 1466, quando Bernardo Ruccellai se casou com a filha de Piero de Medici, cento e setenta convidados sentaram-se em torno da mesa principal, enquanto quinhentos ocupavam as outras mesas: cento e vinte barris de vinho, três mil aves, dois mil e oitocentos pães... (Heers, 1988). Isto se deu, evidentemente, muito antes que a sensibilidade puritana viesse a fazer da língua um órgão mais voltado para a oração que para os prazeres carnais; aconteceu antes que a racionalidade capitalista procurasse impor um caráter utilitário à alimentação e tentasse submeter o sentido do paladar, como tudo o mais, aliás, às várias modalidades de cálculo.

As cenas de comensalidade medieval freqüentemente aparecem ressaltadas por muita luz, proporcionada por janelas, luminárias, lareiras, travessas e talheres lustrosos. A hospitalidade teve um papel essencial na economia da Idade Média, na qual, em princípio, não havia qualquer intenção de investimento. $\mathrm{O}$ alimento ainda não havia sido transformado em uma espécie de combustível, destinado à restauração das energias utilizadas pelo organismo (o substantivo 'restaurante', com este sentido, vale a pena lembrar, apareceria apenas no século XVIII). Se existia o cuidado e, mesmo, a preocupação, de acumular alimentos no celeiro, no quarto ou na adega, tal não acontecia, todavia, senão como uma espécie de previsão, ou melhor, como uma provisão, para as festividades. Em outras palavras, ocorriam tendo-se em mente ocasiões em que as riquezas da casa deveriam ser esbanjadas e em que os tesouros privados deveriam encontrar o seu destino inevitável: dissolverem-se quase integralmente no ambiente público.

A ética da acumulação não colidia apenas com a doutrina religiosa. Contradizia também as disposições fundamentais da aristocracia. Para esta, dispor da riqueza de modo ostensivo e exibicionista, dissipando-a de modo público e sem 
fazer contas muito realistas, constituía gesto de nobreza e de generosidade. Contaminados por este modo de ser, os negociantes ricos muitas vezes se fizeram retratar como seres magnânimos e generosos, esforçando-se por oferecer de si uma imagem pública de nobreza. No entanto, em seu íntimo e seu essencial, o burguês, ao contrário do aristocrata, não consegue ser senão um poupador parcimonioso, calculista e egoísta. Não se livra de ser alguém que gasta dinheiro apenas com inteligência instrumental. Trata-se radicalmente de um tipo humano condenado a sempre trabalhar, não tendo em vista senão um retorno lucrativo e utilitário das despesas que por ventura se veja obrigado a fazer (Gourevitch, 1989).

Nos tempos feudais, a vida de ricos e de pobres não estava ainda, como sabemos, mesquinhamente curvada sobre a poupança, mas derramava-se em generosidades expansivas, com a finalidade de multiplicar amigos, pois estes é que constituíam a verdadeira riqueza. Sobretudo com relação aos nobres, a recomendação era, como nos lembra Duby, a de "para isso jamais olhar a despesa", pois "no quarto onde procriava, na sala onde alimentava, o senhor não detinha poder em seu privado senão na proporção de sua aptidão a dar, e sempre mais" (1991b:82). Do ponto de vista sociológico, esta generosidade era primordial para nutrir a rede de laços de lealdade e dependência pessoal que tecia a sociedade medieval em toda sua extensão. Sob outro aspecto, coerentemente, não deixa de ser de alta significação que fosse habitual que as comunidades da Idade Média se vingassem daqueles que as tivessem ofendido de modo grave justamente destruindo suas moradias. Tratava-se de um gesto quase extremo de ruptura.

Em termos absolutos, exatamente porque acumulavam de modo superposto funções diversificadas, que vieram mais tarde a se especializar, as peças que compunham a casa medieval eram bem maiores do que aquelas que as sucederam no decorrer da nossa história. Compreensivelmente, as habitações da Idade Média não davam ênfase às portas, em especial às interiores, posto que paredes internas não eram numerosas. Muito menos atribuíam importância às fechaduras, o que se aplicava igualmente às trancas de armários e arcas, principalmente se individuais. Nas regiões de temperatura mais fria, as janelas costumavam ser estreitas e a luminosidade resultava escassa. A casa nucleava-se nesses casos em torno da lareira, cuja fumaça se enegrecia a parede e o ambiente, ao mesmo tempo iluminava a sociabilidade e constituía uma verdadeira força centrípeta a atrair pessoas. A lareira servia também de fogão, de secador de roupas, de ponto de iluminação, de lugar de conversa, de aconchego e de afeto (Ariès, 1992).

A importância da casa como reveladora dos modos de vida se manifesta também nos objetos que a compõem, mesmo que esta importância se revele a nós por 'ausências'. Por exemplo, do mais alto ao mais rasteiro na hierarquia social, todos comiam com as mãos durante a maior parte da Idade Média. Se existia um refinamento, este residia na atenção à lavagem das mãos, no fato de não se utiliza- 
rem ambas para tocar a comida, ou no cuidado de segurar os alimentos com apenas três dedos. Ao engorduramento que inevitavelmente resulta deste método de alimentação, respondia-se com o ato de levar os dedos à boca para lambêlos ou de enxugá-los na roupa.

Foi preciso esperar pelos séculos XIII e XIV para que entre as elites esses costumes começassem a ser considerados rústicos, para que fossem associados a hábitos de camponeses e, por conseguinte, se vissem condenados com alguma intensidade. Assim, no século XIII recomendava-se, por exemplo, com uma insistência capaz de suscitar desconfiança, que aquele que por ventura tossisse ou assoasse o nariz cuidasse de se virar para o lado, a fim de que nada caísse sobre a mesa de refeição. No século XIV, já era "indelicado assoar o nariz na toalha da mesa". No século XV, o tom passou a ser um pouco imperativo: "não assoe o nariz com a mesma mão que usa para segurar a carne". Em 1589 o tom de ordem aumentou: "que ninguém antes, durante ou após as refeições suje as escadas" (Elias, 1990:136-137,147).

No entanto, tais condenações não se davam ainda por alegações de ordem higiênica e ocorreram alguns séculos antes de Pasteur descobrir os microorganismos patogênicos. Ao contrário, além de não se legitimarem com base em supostos racionais e médicos, os motivos de saúde, quando presentes, eram acionados exatamente em oposição ao controle corporal. Assim, por exemplo, no tratado de Erasmo sobre as civilidades, De Civilitate Morum Puerilium, 1530, aparecem conselhos do tipo "é insalubre reter os gases", embora o manual sugerisse também, para esses casos, que "a tosse esconda o som"e que "se o vento puder ser solto sem ruído, melhor". Erasmo comentava ainda: "os tolos que valorizam mais a civilidade que a saúde reprimem os sons naturais". Em 1729, no seu Regras do Decoro e da Civilidade Cristã, La Salle continuava aconselhando: "você não deve se abster de escarrar". Os argumentos baseados em contenção corporal não se generalizariam antes do século XIX (Elias, 1990).

Obedecendo ainda ao estilo medieval, tais recomendações foram formuladas com muito humor, irreverência e sátira; com muita ironia, zombaria e deboche. Mas também já se pode perceber nelas alguma seriedade: "não estale os lábios como um cavalo", "não seja como a cegonha, mastigue", "quando a comida for trazida, seja o primeiro a atacá-la, enfie grandes nacos na garganta, como se fosse um porco". Tais recomendações passaram a se justificar por distinguirem os homens dos animais (Thomas, 1988:44), por serem uma questão de boas maneiras, por representarem um signo de distinção social, por não parecer nobre ou cortês proceder diferentemente, por esses cuidados expressarem respeito à presença de outras pessoas... Foi somente por volta de $1670 \mathrm{e} \mathrm{em}$ particular na segunda metade do século XVIII, que os manuais de boas maneiras - não os de higiene - passaram a recomendar com mais ênfase, como gestos convenientes a todos (e, portanto, idealmente obrigatórios não apenas para a 
aristocracia 'fina'), procedimentos como tocar no alimento apenas com o garfo, não se coçar com a mão usada para pegar o prato coletivo, evitar assoar o nariz no guardanapo, entre outros.

O utensílio de mesa mais freqüente na Idade Média era a faca, objeto que não era propriamente um talher: tratava-se na verdade de um instrumento multifuncional que, além de ser portado constantemente, como parte integrante do vestuário, servia para cortar madeira, folhas e galhos, para palitar dentes, matar animais e mesmo pessoas. Com esta ferramenta se partiam pedaços de carnes que eram transportados para as mãos ou depositados sobre a tábua da mesa. Não haveria, entretanto, qualquer recriminação se o pedaço cortado fosse levado diretamente à boca com a própria faca, pois quase nunca existiam pratos individuais. Sem qualquer impedimento inspirado em princípios de higiene ou de preservação da saúde, uma travessa comum circulava ou era colocada à disposição de todos, da mesma forma como também eram coletivas as canecas em que se bebia água, cerveja ou vinho.

A maneira como a comida se apresentava merece registro. Eram animais inteiros que se colocavam diante dos olhos dos comensais. Isso não se aplicava apenas aos de proporções reduzidas, como peixes, aves e coelhos. Valia também para cordeiros e pequenos veados, para não mencionar carnes maiores, caças, porcos e bois. Uma das razões da diminuição do tamanho das peças que vão à mesa poderia ser o encolhimento das unidades familiares, que sabemos ter acontecido praticamente em toda a Europa. Esta explicação, no entanto, não chega a ser de todo satisfatória. O ponto mais fundamental é que hoje nos causaria imensa repugnância o fato de nos depararmos 'pessoalmente' à mesa com aves portadoras de cabeça, pés e penas; com porcos providos de orelhas, patas e vísceras; ou, ainda, ficar face a face com um novilho equipado de olhos, cascos, rabo e chifres.

Em nome do afastamento de tudo o que for orgânico, nossa sensibilidade atual determina que seja indispensável desidentificar o alimento, sobretudo se carne, para que o possamos ingerir sem engulhos. Tal desidentificação deve ocorrer preferencialmente bem longe de nossas vistas, narizes e ouvidos, escondendo-se o sangue, o grito, o cheiro e a sujeira, por meio de atos segregados em bastidores da vida social, como matadouros, cozinhas e açougues - providências que têm despertado crescente atenção desde o início da Idade Moderna (Thomas, 1988). Cada vez mais, além disso, esses atos só podem ser realizados por pessoas que consideramos - talvez exatamente por esta razão - dotadas de um status inferior. Em tempos mais recentes, seguindo estímulos da cultura industrial e acentuando a mencionada tendência à desidentificação e ao afastamento, semelhantes trabalhos devem ser tanto quanto possível executados por máquinas.

Aqui reside um paradoxo simplesmente impressionante de nossa sensibilidade contemporânea. Tais máquinas de matar efetuam a tarefa desidentificadora em escala industrial, tratando multidões de animais como se fossem meros obje- 
tos. Em grande medida, a missão dessa parafernália é não nos deixar atentar para o fato de que, em ilusória substituição a nós, realizam a matança e a descaracterização dos animais de uma maneira extraordinariamente fria e insensível.

Assim, essas engenhocas de matar aos milhares ou milhões são também equipamentos de nos anestesiar e nos eximir de culpa. Semelhantes funções são muito nítidas, sobretudo em uma sociedade baseada na produção industrial que, depois do crescimento das cidades, dispensou os animais do processo produtivo, viu-se em condições de substituí-los, explorando agora as máquinas, mas sem a necessidade de se preocupar com qualquer freio ético - a exemplo do que já tinha acontecido aos próprios animais. Por isso, passaram a ser comodamente possíveis a veleidade e o luxo de as pessoas se imaginarem solidárias dos bichos e de se arvorarem em protetoras dos direitos destes.

Por não requererem para si quaisquer deferências de natureza ética, como se pensa, tais máquinas realizam o prodígio de conjugar o mais insensível e cruel dos morticínios com uma sensibilidade sutil, refinada, delicada, que se proclama incapaz de tolerar o mínimo traço de orgânico, de morte e de decomposição. A extrema sensibilidade contemporânea, desse modo, vira sinônimo de extrema letargia e insensibilidade. Podemos perceber, assim, que esses comportamentos que chamamos de racionais, ao contrário do que tendemos a acreditar, derivam diretamente de uma forma de emoção - pois resultam radicalmente da repugnância. De maneira ambivalente, tais procedimentos são ao mesmo tempo um modo de sentir e de não sentir.

Por esta via - que costumamos chamar de racional -, os alimentos que hoje ingerimos passaram a ser de tal modo disfarçados por maquiagens físicas (cortados, picados, moídos, diluídos, coloridos) e lingüísticas (cardápios em línguas estrangeiras, designações eufêmicas, distinções entre o nome do animal e o do prato que dele resulta), que dificilmente os podemos reconhecer. Nos tempos em que se falava em sacrificar um animal, contudo, a despeito de seus tamanhos, os bichos - quase sempre velhos conhecidos, vizinhos ou companheiros - ou grandes parcelas dos mesmos, eram trazidos para a mesa sem prévio esquartejamento. A mesa era quase como um altar, onde eles eram desmontados, de acordo com um procedimento ritual que proporcionava prazer, exprimia posições sociais e homenageava pessoas. Imagino que este aspecto comunitário possa explicar a recomendação, ainda hoje bastante presente, mesmo que de modo crescentemente artificial, de que cada um deva reservar as melhores porções para os outros (Elias, 1990; Flandrin, 1992; Ribeiro, 1983; Thomas, 1988).

Estes gestos alimentares específicos, que acabei de mencionar, eram perfeitamente compatíveis com as características gerais da casa medieval. Hoje em dia, praticamente todos levamos à boca pedaços bem menores de comida, fragmentos que retiramos de nosso próprio prato, com talheres individuais e funcionalmente especializados. Com freqüência, em nossos tempos, os pratos são bas- 
tante superindividualizados e ultra-especializados pelos seus conteúdos, muitas vezes sendo sucessivamente substituídos no decorrer de uma mesma refeição. No entanto, nem sempre atentamos para o fato de que foi somente aos poucos que surgiram e que foram sendo socialmente absorvidos esses talheres que atualmente nos são tão familiares e cujo manuseio constitui uma gramática de tal modo sofisticada, que talvez só encontre paralelo na invenção de uma língua 'culta'.

Os talheres representam uma imensa parafernália de separação de individualidades e de classes sociais. Sua utilização implica um verdadeiro ritual a requerer anos e anos de aprendizado, envolvendo uma sintaxe - baseada no encadeamento de várias séries paralelas (instrumentos, partes do corpo, tipos de alimentos, momentos da refeição etc.) - que configura significações em escala infinitesimal e que faz altamente expressivo qualquer mínimo desvio. Trata-se de um cerimonial de acesso dificílimo para os pobres e a cuja artificialidade as crianças, mesmo de camadas privilegiadas, resistem o quanto podem. As regras dessa gramática representam também a incorporação de um padrão bastante específico de sensibilidade, que requer, mesmo na esfera biográfica, muitos e muitos anos para se estabelecer com profundidade.

O surgimento dessa tecnologia da mesa em geral foi antecedido por recomendações mais ou menos abstratas, relativas às maneiras de proceder ao utilizarse o instrumental. Antes do aparecimento do copo e da colher individuais, por exemplo, os manuais de boas maneiras aconselhavam enxugar a boca quando se fosse beber na caneca comum. Sugeriam fazer o mesmo com a colher coletiva antes de transferi-la a outras pessoas. De modo análogo, no caso de alguém não conseguir engolir o alimento inteiro, a diretriz de cuspi-lo em algum lugar específico, ao invés de devolvê-lo à travessa coletiva, precede o prato e o garfo individuais.

Não é necessário insistir em que o aspecto de uma casa medieval dependia da situação econômica de seus ocupantes. Este sempre foi no Ocidente um dos principais indicadores de desigualdade social. Não obstante, é importantíssimo observar que alguns característicos permaneciam mais ou menos invariantes, apesar da sucessão dos séculos, da diversidade dos estratos sociais, da mudança dos contextos, se rural ou urbano, das diferenças de região e de atividades econômicas da vida medieval. Tais invariâncias apontam, com certeza, para a configuração de alguns padrões culturais dotados de certa permanência, padrões que nada têm de desprezível, pois estão predestinados a marcar intensamente as sensibilidades ocidentais.

Além dos traços já mencionados, seria interessante frisar a coabitação de homens e animais. A casa era ao mesmo tempo um depósito de instrumentos de trabalho, um celeiro em que se conservavam alimentos e colheitas, uma adega e um galinheiro. Também era um lugar onde se acumulavam restos destinados à alimentação de rebanhos. Era ainda um estábulo, isto é, um espaço por onde circulavam mais ou menos livremente vacas, cavalos, cães, gatos, frangos, patos, 
gansos, porcos, cabras, ovelhas, com seus respectivos ruídos, odores, presas, parasitas e excrementos. O processo de fragmentação - a que tenho feito constante referência e que é uma das chaves para a compreensão das sensibilidades moderna e contemporânea - não a tinha ainda atingido. Deste modo, a casa medieval, não se havendo ainda especializado como unidade exclusivamente dedicada ao consumo, era fartamente marcada pelo trabalho e pelas atividades produtivas.

De acordo com a lógica medieval, a segregação dos animais não precisava ser um princípio observado - característica, aliás, que se conservaria em muitos pontos do território europeu até bem dentro do século XX. Os bichos não eram banidos nem mesmo do leito em que dormiam as pessoas. Os textos e imagens nos falam de animais, crianças, mulheres e homens que se misturavam e amontoavam, trocando cheiros, calores, hálitos e sensibilidades tácteis. Isto valia particularmente para as casas de um só cômodo, uma vez que, naquelas que possuíssem dois, um deles poderia ser reservado, comumente mas nem sempre, à habitação dos bichos. Mesmo quando não fossem habitantes da casa, coisa que as tendências históricas mais fortes iriam aos poucos materializar, ainda que não completamente, os animais dispunham de uma espécie de salvo-conduto, prerrogativa de que continuariam a dispor ainda por muito tempo. Este passaporte lhes permitia entrada franca em qualquer cômodo das residências, a qualquer momento.

A casa típica do camponês medieval era de uma única peça, a ser partilhada com o grupo familiar. Com bastante freqüência, este grupo envolvia três gerações, além de uma prole numerosa. As casas mais ricas e urbanas em geral eram feitas de pedra e telha, em vez de barro, madeira e palha. Possuíam o chão coberto, em lugar da terra úmida, esburacada e muitas vezes empoçada das casas pobres e camponesas. Essas moradas privilegiadas apresentavam pés-direitos elevados, não raro eram dotadas de mais de um pavimento, contrastando com o relativo achatamento das residências humildes. Os cômodos dos domicílios mais ricos certamente também eram mais numerosos, além de muito mais espaçosos em termos absolutos.

Nessas dependências podia-se constatar, contudo, o mesmo amontoamento verificável nas casas dos pobres, uma vez que cada um dos vários cômodos das habitações abastadas era utilizado mais ou menos como se fosse único. Desse modo, a lareira, ou o fogão, encontra-se na sala, em mistura com utensílios de cozinha, com mesas, com cavaletes, com bancos, com tonéis, com sacos de alimentos, além de ficarem contíguos a objetos que mais tarde seriam específicos do quarto (Ranum, 1992). "A sala e o quarto não são espaços estritamente antagônicos (...) eles não são senão aquilo que os homens e as mulheres que os habitam querem deles fazer" (Barthélemy, 1991a:415). Dadas essas condições, é de todo pertinente questionar se não seria um tanto etnocêntrico e parcialmente anacrônico referir-se a quartos, salas e cozinhas no contexto medieval.

Ocorrendo também nas vivendas mais opulentas, o amontoamento que se testemunhava nas casas medievais não pode ser atribuído à pobreza (Roncière, 1991). É preciso, ao contrário, considerar que ele coloca em evidência uma di- 
mensão eminentemente cultural, que já pudemos surpreender em diversas outras manifestações da vida na Idade Média. Nas residências brindadas com múltiplos cômodos, era comum que as pessoas se apinhassem para dormir na sala ou na cozinha, perto do fogão ou da lareira, que eram lugares onde também se punham queijos a secar ou fermentar e em que se amontoavam ou penduravam carnes salgadas e defumadas. Estes comportamentos reproduziam o que se poderia observar também nas residências de peça única.

Ao lado do habitual trânsito de animais, nessas casas abastadas sucedia igualmente de se cozinhar ou se fazerem refeições nos quartos (Collomp, 1992). Semelhantes costumes eram tão profundamente sedimentados, em todas as regiões e em todos os estratos, que puderam tranqüilamente vigorar pelo menos até o amanhecer do século XX. A existência deles desdobra, na prática, um princípio elementar, precioso para podermos entender várias manifestações da sensibilidade do medievo e, por contraste, da nossa própria: a especialização das peças da habitação (quartos específicos para cada sexo, salas de estar e refeitórios, lugares de higiene corporal, cômodos de circulação etc.) ainda não se havia verificado com a nitidez que os séculos posteriores viriam a impor. Como sabemos, esta tendência de especialização é particularmente pertinente no que diz respeito aos hábitos e à sensibilidade das camadas superiores da sociedade contemporânea.

A exemplo do que acontece com os móveis, há um momento em que as dimensões dos cômodos começam a diminuir. Em compensação, verifica-se uma espécie de multiplicação de espaços, processo que ocorre também com o mobiliário. De início, esses espaços menores surgem como subdivisões ou apêndices dos espaços maiores, nos quais se concentram funções ou atividades que posteriormente pleitearão autonomia e segregação. Por exemplo: as pessoas começam a preferir os cantos mais escuros para atividades tais como descansar ou praticar relações sexuais, e os mais iluminados para conversas ou trabalhos domésticos. Foi desse modo que se insinuam e anunciam os primeiros esboços de espaços especialmente destinados à alimentação, à cozinha, à alcova, a toilette, às funções excretórias, à hospitalidade, ao repouso...

No princípio, estes espaços, que lentamente se especializam, são como que dispostos em fileira (Ariès, 1978). Aos poucos, entretanto, são criados recursos arquitetônicos de comunicação seletiva, tendo por finalidade permitir a entrada ou saída de um cômodo sem necessidade de se transitar por outros. Na ausência desses artifícios arquitetônicos, não teria sido possível um isolamento que fizesse valer uma verdadeira intimidade, tal como o que se pôde testemunhar mais vivamente nas construções edificadas a partir do século XVIII. Foi por este meio que se difundiram os corredores, as escadas privativas, os halls de entrada.

A história da casa é extremamente solidária à do corpo. O estabelecimento da separação de corpos é um evidente criador de fronteiras, definidor e redefinidor da idéia de individualidade. Esta separação se integra aos mais ínfimos momentos 
da existência dos seres humanos a que diz respeito, pois passa a exigir que o corpo contenha dentro de si tudo o que ofereça algum risco de transbordar as fronteiras que o definem como individual: os arrotos, os flatos, as transpirações, as salivas, os hálitos, os catarros e, mais tarde, os pensamentos e sentimentos. Tudo isso tinha livre curso nos tempos medievais e, portanto, deverá ser dramaticamente modificado. Agora, novas mentalidades, novas sensibilidades, novas individualidades: devem ser aprisionadas e circunscritas aos limites privados do corpo. É preciso que a arquitetura o viabilize.

Este foi o cenário cultural em que timidamente se inventou um lugar especial para as pessoas evacuarem. Inicialmente esta invenção separava mais os atos que os atores: havia com freqüência, no mesmo lugar, mais de uma latrina, separadas por barras que ajudavam a manter o equilíbrio de pessoas que se acocoravam ao mesmo tempo, lado a lado, freqüentemente mantendo conversação. Em 1558, entretanto, um manual citado por Norbert Elias observa que "não fica bem a um homem decoroso e honrado (...) aliviar-se na presença de outras pessoas". Além do mais, a crença no valor financeiro e simbólico do esterco humano persiste longamente e, mesmo no século XIX, os esvazia-latrinas continuam a exercer a profissão.

Nas páginas das Mémoires de Saint-Simon, ainda se podem surpreender trechos como o seguinte, em que, sem mostrar qualquer espanto, narra-se com toda naturalidade:

O duque de Humières quis que o levasse a Versalhes agradecer ao duque de Orleans, logo de manhã. Encontramo-lo enquanto se vestia, estando ainda na sua adega da qual tinha feito o seu quarto de vestir. Lá estava sobre sua cadeira de retrete, entre seus criados e dois ou três de seus primeiros oficiais...

Este texto, bastante ilustrativo da superposição de funções dos cômodos do palácio, e que cito a partir de Auerbach (1971:374), continua da seguinte forma:

quando Louvois irrompe, numa cena dramática, para junto do rei, para impedir que anuncie oficialmente suas bodas com a senhora de Maintenon, encontra-a justamente se levantando da chaise percée $e$ arrumando ainda as suas vestes; da duquesa de Borgonha, conta SaintSimon que costumava manter as conversações mais confidenciais com suas damas justamente em tais ocasiões.

De nossa parte também não deveríamos ficar surpresos pelo fato de que membros da mais alta aristocracia européia estivessem rodeados de criados e de funcionários enquanto evacuavam. Nem que reis recebessem seus dignitários nesta ocasião: mesmo os príncipes dos séculos XVII e XVIII quase nunca ficavam sozinhos.

Quando a privada que conhecemos, uma espécie de cadeira, apareceu, foi preciso ensinar aos usuários a não permanecerem agachados sobre a mesma. Daí também a invenção correlata, sobretudo em colégios e em construções destinadas aos que deveriam ser ressocializados, de portas vazadas na parte inferior, de modo 
a permitirem vigiar os pés dos que faziam uso das 'privadas' (termo, aliás, bastante impróprio, pois ainda distavam muito de o serem). Também se fez necessário desenvolver um conjunto de regras de comportamento adequado aos novos espaços que iam surgindo - uma etiqueta que começava por regras singelíssimas, tais como: "é indelicado cumprimentar alguém que esteja urinando ou defecando".

Foi preciso, desse modo, contrariar hábitos, para possibilitar o fechamento das funções excretórias e criar seu isolamento (Guerrand, 1991; Braunstein, 1991). Este trabalho foi apenas parcialmente completado, mesmo em setores bastante 'avançados' da sociedade contemporânea. Podemos verificá-lo, por exemplo, nos banheiros públicos de hoje, até em ambientes de certo luxo, em que, ainda que se separem os sexos e as privadas, continua-se permitindo uma certa promiscuidade dos mictórios, apenas simbolicamente apartados por pequeninas divisórias, quando as há. Sabemos, entretanto, o quanto nesses lugares a mistura de cheiros orgânicos e privados, a proximidade de corpos e intimidades são-nos agressivos e suspeitos. Compreendem-se facilmente as razões pelas quais tais espaços nos proporcionam um malestar verdadeiramente punitivo no âmbito de nossas sensibilidades individualistas.

Corolário dessas separações, o estabelecimento de fronteiras e o fechamento do corpo virão a reduzir de modo extraordinário o grau e a natureza da suportabilidade dos cheiros exalados pelas outras pessoas. A nova sensibilidade não somente exigirá uma grande atenção para conter e aprisionar os próprios cheiros, toques, temperaturas etc.: acima de tudo, ela não mais admitirá que o odor do outro invada o nosso território individual, estabelecendo doravante, quanto a isso, os mais sérios tabus. Até mesmo a relação entre o médico e seu paciente sofrerá os efeitos dessa nova sensibilidade. Os antigos métodos de diagnóstico serão gradativamente substituídos. Aos poucos, nada mais de provar a urina, nada de cheirar, de tocar, de auscultar diretamente, de olhar com minúcia. Tudo isso passou a ser excessivamente 'subjetivo'. As exigências de distanciamento, de objetividade e os novos pudores incentivaram o desenvolvimento de 'modernas' tecnologias de separação, baseadas no recato e na discrição (Foucault, 1978).

Na linha das separações mencionadas, os cômodos que primeiro e mais rapidamente se multiplicaram e especializaram foram os quartos. Um dia, estes terrenos virão a dispor de portas, acabarão por ser fechados com múltiplas chaves e mesmo com ferrolhos. Nos contextos medievais, entretanto, estes apetrechos provocavam, em quase todas as pessoas, uma intensa desconfiança. Dentro do espaço doméstico - eminentemente público e coletivo, segundo os hábitos da Idade Média - fundase com o quarto um território particular, privado e especializado, cujo destino foi fundamental para a materialização das práticas e do imaginário do Ocidente.

Em tal território, a tendência à introspecção e à interiorização foi isolando pouco a pouco, no âmbito já próximo do espaço residencial, uma área ainda mais privativa, cujo invólucro passaria a ser constituído pelo corpo de cada homem e 
de cada mulher: a intimidade. É muito importante registrar este detalhe da história da individualização no Ocidente, que outros dispositivos ainda mais sutis viriam a viabilizar sobretudo a partir do século XVIII. Penso, neste caso, na substituição da oração e da leitura realizadas em comum, em público, em voz alta, comportando uma gesticulação e uma expressão corporais extremamente ostensivas, que eram típicas dos velhos tempos, - pelo hábito, primeiro, de rezar e de ler em voz baixa sussurradamente, e depois - como aprendemos a fazer hoje em dia - silenciosa, interiorizada, contrita, solitária e intimamente (Rouche, 1992; Duby, 1979; Sennett, 1989; Chartier, 1992).

Nos primeiros tempos, os quartos eram quase sempre de dimensões minúsculas, se as compararmos às dos espaços especificamente votados à recepção, à hospitalidade e ao convívio comunitário, como, por exemplo, as salas. Os quartos viriam a ser também pessoais, no importante futuro que os aguardava. No entanto, demorariam ainda bastante para se tornarem espaços estritamente individuais e favorecedores do monólogo interior. Na verdade, uma espécie de promiscuidade reinaria por muito tempo nos dormitórios. Uma vez surgidos, os quartos seriam quase sempre 'de alguém' - mas de um alguém ainda coletivo. Talvez seja ilustrativo imaginá-los como um "privado gregário", para usar de maneira um pouco deslocada a feliz expressão de Régnier-Bohler (1991:323).

Tais cômodos possuiriam separações. Todavia, essas separações não passariam no início de tabiques de madeira, limitando-se muitas vezes a serem peças de pano ou tapeçaria. Os quartos disporiam de camas. No entanto, esses leitos abrigariam simultaneamente vários ocupantes, quase nunca respeitando a partilha de sexos e idades. Uma única cama poderia acolher não apenas um casal, mas também seus filhos, pequenos ou nem tanto, vários irmãos ou irmãs, amigos, criados a serviço de um mesmo senhor, estranhos que recebiam a mesma hospitalidade... A iconografia e os textos mostram em abundância guerreiros, estudantes, doentes, pobres, entre outros, dormindo vários em uma mesma cama (Contamine, 1991).

Os quartos permitirão o confinamento da nudez e das relações sexuais. Não obstante, por muito tempo elas ainda terão lugar diante de espectadores mais ou menos distraídos, que seriam pequenas platéias, formadas por criados ou não (Roncière, 1991). Ao surgirem, os quartos já prometem se transformar nos espaços por excelência da solidão e da fuga dos olhares de outrem, mas ainda não o são. Ao contrário: são cenários de muito intensa sociabilidade noturna e mesmo diurna, cômodos onde se recebem visitas, onde reis concedem audiências e onde muitas vezes tocam escrófulas solenemente. A diferença entre o quarto e a sala é, e permanecerá por muito tempo, uma questão de grau de privacidade, não de natureza. Com isso quero dizer que não havia saltos, que não se constatavam abismos no interior do espaço doméstico - de modo semelhante ao que também ocorria no que diz respeito à relação interior-exterior da moradia. 
Apenas por volta do século XVII começa a se difundir a camisola de dormir, como um tímido separador de corpos individuais. A cama individual já vinha muito lentamente rompendo com a cama coletiva, em certos segmentos da população, sobretudo nos mosteiros e em alguns colégios. Ela antecedeu em muito o quarto individual - como sabemos, um sonho ainda impossível para a maioria dos indivíduos integrados à sociedade individualista, mesmo tão tardiamente quanto no final do século XX. Esta cama individual, por sua vez, foi precedida por leitos mais ou menos privativos, que comportavam separação ótica, mas não permitiam ainda a separação auditiva ou olfativa: são as camas com cortinas, que hoje conhecemos apenas em filmes, museus, livros ou gravuras.

Muitas vezes destinados a casais, estes móveis encortinados deixam muito evidente que pretendiam separar seus ocupantes de outras pessoas que freqüentavam o mesmo ambiente. Eles refletem claramente um estágio ainda balbuciante da história da privacidade, um momento em que a fronteira da intimidade se limitava prosaicamente a antepor frágeis objeções ao olhar. Prosaicamente, mas não sem propósito, pois no olhar já se materializava a ascendência da visão como sentido culturalmente privilegiado e como indicador de distanciamento. Assim, às vésperas do Iluminismo, o manual de La Salle advertia: "o decoro exige que ao nos deitar escondamos de nós mesmos o próprio corpo e evitemos lhe lançar até os menores olhares".

De diversas maneiras, por um lado, os quartos contêm a tendência mais limpidamente observável na transformação das mentes e dos modos de vida medievais. Tais tendências atingem igualmente a rua, a casa, seus cômodos e mesmo o corpo: fazer passar para o interior aquilo que outrora se desenrolava mais facilmente ao ar livre e no exterior. No início, e por muito tempo, essas tendências definem graus diferentes de transparência e opacidade dos espaços domésticos - em geral passagens sem grandes soluções de continuidade, em vez de abruptos impactos provocados por mudança de natureza.

Por outro lado, insinua-se cada vez mais fortemente nessas tendências a substituição dos espaços polivalentes e multifuncionais por territórios dotados de destinação mais rigorosamente predefinida, por espaços menos passíveis de comportar misturas ou sobreposições, inclusive e mormente aquelas resultantes da proximidade entre os senhores e seus serviçais. Tratava-se cada vez mais de conceber uma habitação que fosse bastante pequena para que nenhum 'estranho' a pudesse habitar. Ao mesmo tempo, tal residência deveria ser suficientemente espaçosa, a ponto de os pais nela poderem dispor de um território, separado dos terrenos dos filhos e dos empregados. Um terreno em que os pais pudessem viver sem serem observados em sua intimidade, mas sem perderem a possibilidade de vigiar filhos e serviçais (Donzelot, 1986).

Mesmo nos mosteiros, sob o abrigo do claustro que protegia das corrupções do mundo, a vida era comunitária. Na Idade Média até a solidão se vivia em grupo, como lembrou Duby (1988b). Algumas dezenas, por vezes centenas de homens, 
quase sempre oriundos da aristocracia, nos mosteiros formavam uma fraternidade. A vida pública estava aí também no centro da vida privada, como durante quase toda a história do Ocidente. Dentro ou fora dos mosteiros, viver privadamente era antes de tudo viver em casa, em família. O grupo familiar constituía o coração do privado, mas era também o contrário disto: era o lugar em que a privacidade se fazia pública. As fronteiras eram tênues. Ainda não era chegado o tempo em que a pessoa que se encontrasse na sala evitaria se dirigir a quem estivesse no quarto, e quem se encontrasse fora não poderia falar com quem estivesse dentro do banheiro. Mesmo no interior da vida privada familiar, foi com grande dificuldade e com muita demora que surgiu o privado individual.

Um exemplo razoavelmente ilustrativo desta delonga: até o final do século XVIII, mesmo para as elites, não se havia ainda concretizado o individualismo que se traduz pelo isolamento noturno. Ainda nesse meio social, o quarto não constituía, para a maioria, o templo da vida privada, um espaço de intimidade construído como se fosse um abismo abrupto no centro da esfera doméstica. O quarto ainda estava longe de ser o lugar mais íntimo dos casais, o recinto em que, dos modos mais ousados, segundo os imaginários, seria possível transgredir a moral sexual dominante. A história dos dormitórios nos ensina que essa transgressão, de maneira irônica, acabaria por se tornar algo socialmente autorizado: os quartos não passariam, neste sentido, na maior parte das vezes, de espaços culturalmente destinados à transgressão conformista e controlada de regras de procedimento sexual. Passariam a ser lugares propícios a mise-en-scène de modelos socialmente padronizados e aprovados para a conduta sexual desviante.

Até o século XVIII, a maioria dos leitos conjugais ainda nem mesmo é circundada por cortinas. Muito menos é envolvida pela espessura das paredes do quarto 'de dormir', pelas fechaduras inspiradas pelo recato, possessividade ou sentimento de ciúme. A Idade Média permanece: não é ainda o tempo em que as coisas 'íntimas' serão feitas às escondidas, em espaços reclusos e especializados para sufocar risos, cochichos, sussurros, murmúrios, gritos... Ainda não é chegado, para a maior parte das pessoas, o tempo da decência do pernoite, do pudor associado ao sexo e às funções corporais, sobretudo excretórias.

Também se está muitíssimo distante, nos séculos medievais, dos tempos que viemos a conhecer, em que os atos de vida privada, depois de haverem encontrado um espaço dentro da família, acabarão escapando do círculo doméstico e serão praticados principalmente fora de casa. Sim, porque um tempo chegará em que o individualismo e o desejo de privacidade atingirão pontos tão críticos, que as pessoas acabarão preferindo o anonimato extremamente individualizante de alguns lugares públicos. Por essa razão prosperam em nossos dias os estabelecimentos públicos especializados na viabilização de gestos íntimos e na preservação do secreto - como motéis, prostíbulos discretos, saunas escuras, cabines reservadas para masturbação etc. 
Não havia como se isolar nos espaços medievais, naquelas casas povoadas, abertas. Por muito tempo, todos viveram as mínimas cenas da vida familiar ou cotidiana completamente às claras ou em penumbra: toilette, evacuação, gravidez, parto, morte, menstruação, relações sexuais... Até que se inventasse a cama com cortinas, desejando-se alguma privacidade (mas não era sempre o caso), o ato sexual deveria ser praticado sob as cobertas ou na escuridão. De acordo com a regra geral, segundo a qual uma modificação dos antigos dispositivos antecede a invenção de novos aparatos, uma cama 'íntima' precedeu nessa história o quarto individual.

Mesmo no século XVII, em gravuras reproduzindo interiores de residências de famílias francesas de camadas média e superior - vanguardistas, portanto, quanto ao cultivo desses requintes -, pode-se muitas vezes perceber o leito como parte do mobiliário da sala. Antes de se cercar de cortinas, uma cama íntima deslizou sutil e lentamente por um espaço público, em busca de recantos mais escuros e discretos. Sob tais condições, somos vivamente convidados a especular a respeito de como os rituais eróticos e seus preliminares devem ter acontecido. Nesses tempos de pouca ou nenhuma intimidade, como se davam as relações 'íntimas'? Eram breves? Eram livres? Abafadas?

Havia mesmo uma certa formalidade cerimonial a consagrar essa liberdade relativa ao 'íntimo' que pode ajudar a imaginação, uma vez que são raríssimas as informações sobre este assunto. Os costumes dos ritos matrimoniais podem nos dar uma idéia da ausência de importância desta privacy. Em várias regiões da Europa medieval era hábito uma espécie de procissão ao quarto ou à cama, liderada pelos padrinhos do casal. A noiva devia ser completamente despida pelas damas de companhia e os nubentes presenteados com suas camisolas de dormir. $\mathrm{O}$ leito nupcial deveria ser montado na presença de testemunhas, para que o casamento fosse válido - mais tarde, este leito seria abençoado por um sacerdote, como garantia de fecundidade e fidelidade (Barthélemy, 1991a). Como tudo na vida medieval, a cópula também não precisava ser ocultada ou atenuada por eufemismos simbólicos. Não foi sem propósito, aliás, que uma das primeiras regras do jogo do amor cortês fosse exatamente a obrigação da discrição e do segredo, "impondo aos amantes viver a dois uma solidão oculta (...) primeiro botão do que se tornará para nós a intimidade" (Duby, 1991a).

Eram essenciais aos ritos medievais de matrimônio a expressão licenciosa e um simbolismo que, conforme os parâmetros de nossa sensibilidade contemporânea, soariam grosseiros. A exposição dos lençóis no dia seguinte à consumação das núpcias pode ser um exemplo ilustrativo dessa ritualidade. A alegria obscena predominava e todos os orifícios corporais podiam servir a esse objetivo, de que a farsa e a canção lascivas constituem um gênero bastante característico. Havia nos tempos medievais, por assim dizer, uma alegoria erótico-eclesiástica, de que ainda permanecem resíduos nos nossos ritos matrimoniais. A Igreja oficial não era capaz de dominá-la. Nem mesmo o puritanismo da Reforma teve a potência de abolir inteiramente a publicidade do casamento-cama, que permaneceu viva bas- 
tante além do século XVII, sobretudo nos meios populares. Essa publicidade não desapareceu totalmente ainda hoje, continuando bastante viva em algumas regiões, particularmente, como se sabe, às margens do Mediterrâneo.

Em fins da Idade Média, entretanto, com variações segundo as classes e os países, estes costumes começam a mudar gradualmente, expressando-se em modificações nos padrões de intimidade - constrangimento, culpa, vergonha, pudor - no que concerne ao sexo. E o casal obtém permissão ou incentivo para se deitar vestido. As antigas franqueza e liberdade tornam-se ao poucos procedimentos chocantes. As relações sexuais são transferidas para os bastidores da cena social e isoladas no domínio mais secreto da vida familiar e pessoal. Principia-se a requisitar de cada um sigilo e tabus sobre a vida sexual, além de alta dose de controle dos impulsos e dos ardores corporais (Elias, 1990). Algo como uma moralização da sexualidade preguiçosamente começa a se impor - e de modo tão intenso que, quando os princípios vitorianos tiverem determinado silêncio quase total com relação a tudo que se referisse à sexualidade, paredes, cortinas, cobertas, móveis, portas, janelas etc., quase não falarão sobre outra coisa que não fosse sexo (Foucault, 1985).

Pode parecer inteiramente contraditório, mas o aparecimento dos cômodos, das paredes, das portas, das chaves, das cortinas e das distâncias corporais expressa antes de tudo a tendência de as pessoas cada vez mais se observarem umas às outras, de se vigiarem mutuamente e de cada um se impor como autoridade sobre o próximo. Proibição de ver e estímulo a olhar constituem duas faces da mesma moeda. Distanciamento obrigatório e desejo de aproximação representam os dois lados da mesma folha.

Isso nos ensina também que as relações sociais neste momento estão assumindo um matiz muito tenso, aumentando a coação exercida por uma pessoa sobre outra e exigindo mais enfaticamente um 'bom comportamento' - exigência presidida por sutis manifestações do esconder e do mostrar, que nós viremos a conhecer bastante bem. Desse bom comportamento, a capacidade de auto-observação, de se fazer objeto de si mesmo, será um dos princípios essenciais. É essa habilidade que virá a possibilitar o autocontrole, a auto-avaliação, a boa apresentação de si e o tornar-se amo de si próprio. O distanciamento conceitual em relação a si, essa objetividade relativa à própria subjetividade, exige controle emocional, obviamente. A visão 'psicológica' de si representa, por conseguinte, uma estranha e paradoxal insensibilidade a si.

A observação silenciosa de si e dos outros como um princípio de ordem pública é, com certeza, uma das mais profundas transformações do século XIX (Sennett, 1989). Nesse ponto, já não se tratará mais, propriamente, apenas de um poder que atua 'de fora' sobre mentes e corpos, no sentido de obrigá-los a fazer o que se quer que eles façam, de um poder pessoal e visível. Tratar-se-á, antes, de um poder, muitas vezes anônimo, que sabe como fazer corpos e mentes operarem 
da maneira como se quer que operem (Foucault, 1975). Tratar-se-á doravante de uma ação de si sobre si, de uma maneira de ser. De um modo de existir que fabrica um tipo de auto-sensibilidade - uma subjetividade auto e hetero-objetificante - totalmente indispensável à nova sociabilidade individualista e ao novo funcionamento do poder.

Vejamos uma ilustração singela e caricatural: a abordagem sexual direta, bastante comum nos tempos medievais (Braunstein, 1991), movida pela espontaneidade e pela simplicidade, pelas facécias, libertinagens e obscenidades, cai lentamente em desuso nesse novo cenário governado pelo autocontrole, pelo racional, pela domesticação da linguagem falada e corporal, pela subordinação dos afetos às formas de etiqueta. Nada disso é difícil de compreender. A palavra 'cortejar', a propósito, é bastante significativa nesse contexto. Ela surgiu em fins do século $\mathrm{XVI}$, apontando para uma nova maneira de se prepararem e de se realizarem as relações sexuais, maneira presidida por códigos de conduta que ritualizam uma aproximação lenta e cerimoniosa do casal, dramatizando uma manipulação muitíssimo complicada de paredes sociais, arquitetônicas, corporais, individuais psicológicas e, sobretudo, íntimas.

Tais fronteiras passam agora a constituir verdadeiras muralhas, extraordinariamente sensíveis e vigiadas, sujeitas a susceptibilidades das mais variadas tonalidades. Muralhas entre pessoas. Muralhas interiores. Muralhas de medos profundamente arraigados. Medo de ver o outro. Medo de tocá-lo. Medo de ser visto. Medo de ser afetado (Elias, 1993; Corbin, 1991). Medos que previnem as mínimas transgressões do comportamento socialmente aceitável. Medos que levam a parar de sentir pelo medo de demonstrar sentimentos. Medo de desejar. Mas também medos de suscitar desejos. Desejos que portarão as marcas indeléveis de todos esses medos. 


\section{0 \\ Exterior e Interior}

Nada aproveitaríamos, para os propósitos deste trabalho, se optássemos pelo caminho fácil de, situando-nos no interior de nossa sensibilidade corporal contemporânea, negar a existência de práticas de asseio ou de gestos purificatórios em outros tempos e em outras culturas. Tal caminho seria provavelmente o mais curto para nada entendermos de nossas próprias práticas e concepções, desprovidos que ficaríamos dos pontos sutis de comparação e de contraste que poderiam nos permitir colocar em evidência as dimensões menos ostensivas de nossos costumes. Um olhar retrospectivo sobre práticas de limpeza parecidas com os usos contemporâneos pode perfeitamente mostrar - o que não é absolutamente inusual em antropologia - que estas são similares onde se poderia pensar que fossem diferentes e, ao mesmo tempo, muito diversas onde poderiam parecer semelhantes.

Verificaremos, nas páginas que se seguem, que os signos de limpeza corporal no passado foram simultaneamente parecidos e diferentes dos nossos: davam ênfase a traços que depois se tornaram acessórios, faziam pouco caso de detalhes que para nós vieram a ser essenciais. Aqui e ali, as práticas antigas sugerem a existência de faltas e, sobretudo, de imprecisões, transmitindo a impressão de que o nosso comportamento de limpeza corporal se tenha tornado cada vez mais exigente, preciso e minucioso. $\mathrm{Na}$ verdade, contudo, o que encontraremos de mais importante será uma profunda modificação filosófica e existencial sobre como entender o que sejam vida, corpo, saúde, assim como sobre quais são os seus valores e suas associações simbólicas.

Os gregos, por exemplo, poderiam a priori parecer - a nossos olhos habitualmente idealizadores da Antigüidade clássica - um povo amante do que costumamos chamar civilidades. Semelhante conceito talvez se ofuscasse, ao menos para os mais sensíveis entre nós, se levássemos em consideração o pouco caso com que de fato eram tratadas, nas cidades helênicas, as questões de higiene corporal. Até recentemente, os arqueólogos ainda não haviam encontrado o menor traço de uma preocupação específica com esta matéria: sendo os gregos contrários a fazer demasiado esforço corporal para assegurar comodidade ou luxo, e 
não sendo comuns os encanamentos de água, as cidades gregas do século V a.C. praticamente desconheciam qualquer aparelhagem sanitária de caráter público, ou mesmo qualquer construção que fizesse da evacuação algo reservado. No entanto, há textos que se referem ao ato de acocorar-se diante de outrem, tecendo sobre o mesmo observações jocosas - considerações que envolvem atenção especial direcionada para o ato em si de evacuar, pouca importância atribuindo ao fato de ser 'em público' (Mumford, 1977). Na África romana (Thébert, 1992), resíduos arqueológicos de algumas residências ricas exibem latrinas 'privadas', mas estas eram com freqüência dotadas de dois lugares...

Públicos eram também os ambientes gregos destinados ao banho. Porém o termo, naquele contexto, não significava o mesmo que representa hoje para nós: associava-se à paixão pela vida gregária, sendo os banhos privados acompanhamento de ocasiões especiais, freqüentemente de caráter sexual, com que as elites, dispensadas de transportar com as próprias mãos a água que jorrava das fontes, premiavam-se a si mesmas. Públicas foram igualmente as termas romanas, vastos recintos capazes de acolher imensa quantidade de pessoas, não raro ambientes dotados de salões monumentais, equipadas com banhos quentes, mornos e frios, com salas de massagens, com espaços especiais para refeições e para conversas, com lugares específicos para jogos, esportes, brincadeira e mesmo, às vezes, bibliotecas ou salas de leitura.

"A melhor parte da vida privada transcorria em estabelecimentos públicos", diz-nos Paul Veyne (1992:194). O banho em Roma não era uma prática de higiene, mas um prazer complexo, mais ou menos como a praia entre nós. Não havia casa de rico na qual os equipamentos destinados ao ato de banhar-se não ocupassem vários cômodos especialmente arranjados. Não havia cidade romana sem pelo menos um lugar para os banhos públicos. Por um pouquinho de dinheiro, os pobres poderiam passar horas em um ambiente luxuoso, uma generosidade dos poderosos. Ao menos como regra geral, os sexos eram separados nas termas romanas; mas estes territórios foram gradativamente tornando-se ambientes de prazer, inclusive sexual. Além disso, proporcionavam à população um lugar fechado e quente, em que se poderia fugir ou proteger do frio do inverno (Veyne, 1992).

Mais do que uma necessidade higiênica, os banhos romanos talvez se explicassem como cerimônias rituais de sociabilidade. Tais celebrações tinham o corpo como uma espécie de altar principal: as termas eram um templo, ao qual não faltavam os exibicionistas, os voyeurs e os fanáticos pela forma física. Nelas compareciam também aqueles que "vinham hoje se curar da ressaca de ontem", e se preparar para a esbórnia etílica e sexual da noite seguinte. As termas não só encontravam paralelo apenas na arquitetura do panteão, como também se multiplicavam: onde quer que fossem e deixassem suas marcas, os romanos do inicio da era cristã empreendiam imediatamente a construção de edifícios destinados a essa finalidade. Estes prédios talvez fossem simultâneos ou mesmo antecedessem aos 
templos religiosos e às fortificações. A higiene, contudo, ainda que pudesse ser uma conseqüência das termas, não era em absoluto sua causa. Pensava-se fundamentalmente em propiciar a todos uma vida agradável.

Este mesmo espírito continuou prevalecendo durante o período medieval, embora com diferenças importantes. O banho privado aparece de modo plenamente significativo apenas no século XIII, materializado em geral em uma espécie de tina colocada no quarto de dormir ou na cozinha - o que, como estávamos vendo nas páginas precedentes, não chegava a eclipsar o seu caráter público. Em Londres, os banhos quentes em residências privadas foram especialmente autorizados em 1417, permissão que configura o primeiro passo de uma longa história que, como sabemos, terminaria por tornar a privatização do banho quase obrigatória.

O banho público definia a atitude medieval mais parecida com o que hoje chamamos de limpeza corporal (Mumford, 1961, 1977). As casas de banho se faziam presentes em praticamente todas as cidades, e nas maiores poderiam ser encontradas em quase todos os bairros. Muitas eram propriedades particulares de uma família; outras, mais numerosas, geridas pela municipalidade. Por volta de 1300 , havia, por exemplo, onze delas em Ulm, doze em Nuremberg, dezessete em Augsburg, vinte e nove em Viena, quinze em Frankfurt (que contava com vinte e nove em 1387). O costume do banho na Idade Média não era apenas urbano, pois, apesar dos preconceitos que se agravavam pouco a pouco contra os camponeses, acusados de sujos, não era a falta de imersão o principal argumento de acusação utilizado. Importante observar: segundo o dicionário Petit Robert, até 1640 o termo 'limpo' ainda não era o contrário de 'sujo'.

A freqüência individual às casas de banho raramente era inferior a um por quinzena e amiúde se dava semanalmente. Estes números não consideram aqueles banhos que aconteciam ao ar livre, durante o verão, em um lago, jardim ou rio. Não se tratava de um ato espontâneo apenas: por volta de 1292, era habitual que um homem percorresse Paris gritando e convocando as pessoas para banhos e saunas. Naquela época, havia trinta e duas delas na cidade. Os corpos nus transpiravam e se espojavam lado a lado no vapor de uma água aquecida com lenha ou carvão, em salas equipadas com banheiras cercadas por ferro: a iconografia nos mostra mistura de sexos, de idades e de corpos nus; contém toques, carícias e leitos em que repousam casais entrelaçados.

Talvez dando seqüência à tradição romana, o banho medieval estava vinculado a uma sociabilidade lúdica e festiva, com suas distrações, dissipações e, muito freqüentemente, excessos. Os banhos eram encontros em que as pessoas comiam, bebiam, deixavam-se massagear e se divertiam. Não obstante, as casas de banho medievais em quase nada podem ser consideradas como equivalentes às instituições de higiene que muito mais tarde viriam ajudar a implementar a disciplina pessoal e política, bem como reforçar as normas de separação social. No con- 
texto medieval, a água funcionava como uma espécie de suplemento do prazer: adicionava-se à vontade de desregramento e adaptava-se às finalidades do banho, finalidades que eram eminentemente a brincadeira e a transgressão.

Não se trata de dizer, é claro, que toda lavagem corporal estivesse ausente. De qualquer forma, era muito pouco lembrada quando o tema fosse o banho. Limpar poderia ser uma conseqüência provável, mas não constituía em absoluto a motivação fundamental do relacionamento com a água (Vigarello, 1985). Quando alguém chegasse de uma viagem, por exemplo, o que se reparava era o brilho ofuscado das espadas ou as cores prejudicadas das roupas. Nada relativo à poeira no corpo, suores, fedores, era colocado em evidência em situações desse tipo; nada vinha à tona falando de limpeza ou de sensações íntimas. Entretanto, tinha-se como grosseria usar a mesma roupa durante todo o tempo de uma longa viagem. Na sensibilidade medieval concernente à sujeira não havia propriamente uma preocupação com as condições imediatas da pele ou dos orifícios corporais. De certa forma, no que se refere à relação entre limpeza e sujidade, era como se a existência do corpo estivesse delegada a outros objetos que o envolvessem ou o prolongassem. O tema da limpeza era quase por completo orientado para estes objetos (Vigarello, 1985).

Os inventários de pós-morte da Idade Média são ricos em referência às bacias de lavar as mãos, inclinando-nos a acreditar que, ao menos em certos meios sociais, fosse este um ato recorrente: os textos de viajantes registram com consternação a ausência desse costume em algumas terras que visitavam (RégnierBohler, 1991). Mas os textos também ensinam aos historiadores que a obrigação de lavar as mãos e o rosto era principalmente de ordem moral, não de inspiração sanitária. Seu objeto era a decência, antes de ser a higiene. Dar água para as mãos de uma pessoa era signo de polidez, gesto de amizade. Fazia parte das normas ensinadas aos pagens nas cortes senhoriais.

De modo bastante semelhante à imersão, que, como parte do rito de acolhida, o anfitrião deveria oferecer quando da chegada de seu hóspede, ou de maneira análoga àquele banho a que se submete o rapaz durante o rito de sua investidura como cavalheiro ou, ainda, de forma similar àquelas abluções de que eram objeto os recém-nascidos e os defuntos (Duby, 1988a), o ato de lavar as mãos pertencia a um código de relações sociais, mais do que a uma linguagem de limpeza e higiene corporais. Tanto é verossímil esta tese, que alguns dos primeiros manuais de boas maneiras recomendavam com a maior sem-cerimônia e simplicidade: "não escarre na bacia quando estiver lavando as mãos” (Vigarello, 1985; Elias, 1990).

A palavra 'promiscuidade', se aplicada ao banho coletivo medieval, com certeza comportará um veio etnocêntrico. Esta qualificação derivará diretamente do isolamento em que vivem nossos contemporâneos, assim como dos distanciamentos sociais que hoje em dia somos obrigados a observar. Nos tempos medievais, contudo, a proximidade física nada apresentava das conotações susci- 
tadas pela palavra 'promíscuo'. Naquele período, as pessoas tinham o hábito da proximidade física e da mistura em várias outras situações da vida, independentemente dos banhos. Isto se dava, por exemplo, quando as pessoas se faziam expurgar, com auxílio daqueles que amavam, dos parasitas que pululavam nas barbas, nos cabelos e nas roupas. Mais ou menos como em nossos tempos ainda é possível encontrar casais de namorados que se deliciam espremendo-se as espinhas, na Idade Média piolhos e pulgas eram motivos para uma sociabilidade que os antropólogos estão acostumadíssimos a reconhecer nas mais diferentes culturas. Trata-se de gestos que crescentemente consideramos repugnantes: no entanto, são práticas que propiciam ocasiões de expressar ternura entre amantes, entre adultos e crianças, entre familiares... Com admirável freqüência, também exteriorizam a ritualização dos distanciamentos na hierarquia social.

Observemos que as teorias existentes antes do século XIX de modo algum imaginavam que os parasitas do corpo humano pudessem derivar de alguma insuficiência de ordem higiênica. De acordo com as concepções então vigentes, estes seres brotavam do corpo em virtude de um excesso de humores: pensava-se que pulgas e piolhos nascessem da transpiração mal controlada, supunha-se que fossem as substâncias humanas degradadas que lhes dessem vida. Reduzir os humores, deste modo, poderia ajudar a suprimir tal proliferação. Acreditava-se que aqueles pequeninos animais tivessem geração quase espontânea, saindo do interior corporal, fermentados pelas misturas de matérias. Nasciam do corpo, como alguns vermes pareciam sair da carne em decomposição. Eram o trabalho da morte sobre a carne ainda viva. Não se evocava, pois, a limpeza como tal. Os parasitas eram considerados sobretudo um estado do corpo (Vigarello, 1985).

A partir do século XIII, entretanto, mesmo a mistura familiar, a que me referi anteriormente, começou a ser proibida. Em Ravena, um regulamento da época proibiu expressamente que se catassem piolhos em público, o que na verdade significava, nos termos dos padrões relacionais em vigor, que a proibição deveria viger em quase sempre. Com muito mais razão, passaram a ser objeto da reprovação das autoridades, sobretudo das religiosas, os banhos coletivos e públicos. $\mathrm{O}$ alto clero e os dignitários positivamente não aceitavam o fato de as termas se terem transformado em recintos dedicados ao prazer corporal, em centros de prostituição notória e permanente, além de terem passado a servir como casas de encontro e como lugares de alcovitagem e desregramento (Rossiaud, 1991). A palavra inglesa stew, a propósito - que hoje ainda pode ser traduzida por bordel -, designava naquela época as saunas ou as estufas.

Assim, em decorrência dessas pressões, haverá um momento em que os poprietários das termas serão obrigados a escolher se seus estabelecimentos destinar-se-iam a mulheres ou a homens, nunca a ambos (Gimpel, 1976). A determinação conexa, de que as saunas funcionassem em horários alternados conforme os sexos passou cada vez mais a ser levada a sério, esboçando um futuro que 
viemos a conhecer ainda com força respeitável. Entre os séculos XIV e XV, proibiu-se a entrada de homens casados e reconheceu-se oficialmente a casa de banhos como um lugar de prostituição (Vigarello, 1985).

A interiorização das normas que as cortes senhoriais e o clero poderoso difundiam acabou deslocando insensivelmente as percepções da decência e do pudor. A nova sentimentalidade, privatizante por excelência, criou o amor possessivo, que passou a estimular, por ciúme, o abandono das termas coletivas e sua substituição, em alguns casos, por saunas privadas. A história das saunas, desse modo, ilustra a lenta instauração das distâncias físicas, expressões das novas distâncias sociais, refletindo o aparecimento de limiares. Com eles, certas misturas se tornaram mais difíceis, certos contatos não mais eram vistos como naturais. Ao se atingir o século XVI, a instituição dos banhos públicos - e mesmo dos privados - levaria apenas alguns decênios para se apagar quase por completo. A nova moral teria enfim triunfado sobre o exibicionismo e o 'voyeurismo', doravante considerados pecaminosos e representantes de gravíssimos perigos para a saúde da alma.

O próprio clero começou dando o exemplo, pelo menos em teoria. Eram minuciosas as precauções que passaram a cercar os banhos e seus 'perigos' - de ora em diante, uma prática considerada fundamentalmente imoral, propiciadora de maus pensamentos e, acima de tudo, de desejo sexual, despertado de modo particular pela água quente. No mosteiro de Cluny, por exemplo, as lavagens deveriam ser rigorosamente privadas, recomendando-se que as completas se fizessem duas vezes por ano, normalmente em festas que evocavam renovação - Natal e Páscoa -, sem que se descobrissem no entanto aquelas partes do corpo que começavam a ser vistas como pudentas. $\mathrm{O}$ banho quente, em particular, passou, além disso, a ser encarado como um comportamento de classes decadentes, como símbolo de um excesso que amolece, que degenera a natureza dos homens, configurando, em síntese, algo que a nova ética do trabalho associa à preguiça e ao ócio.

A nudez, por sua parte, assume uma inédita gravidade nesse contexto, não obstante o fato de que fosse possível presenciá-la ainda por algum tempo. Esta permanência adicional da nudez se deveu ao fato de que as mulheres aristocráticas continuassem a se mostrar nuas diante de seus criados de sexo masculino, e que os nobres persistissem em ficar despidos diante de seus serviçais. Contudo, a nudez que se conservou exibia um sentido completamente novo: permanecia possível apenas em virtude das relações hierárquicas e continuava a acontecer somente porque os criados não tinham importância alguma - mais ou menos como hoje em dia, em geral, não nos incomodamos muito em ficar desnudos na presença de nossos animais, particularmente diante daqueles que antropomorfizamos menos. No final do século XVIII, entretanto, este processo já terá caminhado bastante, de modo que somente a serviçais do mesmo sexo se permitirá ver os senhores sem roupa (Sennett, 1989).

Por estes caminhos, o pudor e a culpa efetivamente começaram a se ligar ao corpo e à sua visão, expressando o desprezo pelo carnal que, durante os séculos seguintes, guiaria ainda mais intensamente a sensibilidade no Ocidente. Entre 
as grandes revoluções culturais ligadas ao triunfo do cristianismo e do capitalismo, uma das mais importantes talvez tenha sido a que se refere ao corpo. Mesmo as doutrinas da Antigüidade que privilegiaram a alma não concebiam virtude ou bem que não fosse exercido através da mediação corporal. Nos tempos modernos, porém, houve um grande revolvimento na vida quotidiana dos homens, materializando-se em novas relações com a corporalidade. Tal revolvimento está associado à eliminação do teatro, do circo, do estádio, das termas, dos espaços de sociabilidade e de cultura, que, pelo menos desde a antiga Grécia e a vários títulos, exaltavam, festejavam ou utilizavam o corpo (Le Goff, 1985).

Nessa linha, os pensadores cristãos recusaram o prazer do corpo e da água. Não apreciavam ser corporalmente limpos e só se banhavam muitíssimo raramente. A barba suja de um filósofo constituía com freqüência um indício de austeridade, do qual ele se orgulhava. O próprio batismo - em sua origem um ritual coletivo, que comportava uma total imersão de homens e mulheres nus na piscina octogonal contígua a toda catedral - foi abandonado em favor do rito individual e de aspersão, que hoje conhecemos. Desta maneira, os banhos, que se mantiveram durante tanto tempo no Ocidente, inclusive nos mosteiros, transformaram-se em coisa raríssima, cada vez mais destinada aos enfermos, em especial (Ariès, 1992; Rouche, 1992). Vem de muito longe, portanto, uma vontade de afastamento do corpo que encontrou sua plena realização no século XIX, quando as partes corporais que não pudessem ser vistas também não poderiam ser abertamente objeto de discurso.

No limite, essas tendências repressoras da apresentação pública do corpo, que acabaram por sufocar o banho, iriam provocar o aparecimento de uma esdrúxula forma de erotismo. Dado que os principais componentes do corpo humano deveriam estar cobertos e que os corpos, especialmente o feminino, por causa das vestimentas, passaram a não mais apresentar qualquer relacionamento, mesmo metafórico, com a forma do corpo nu, sobretudo a partir do século XVIII, pequenas coisas - cachos de cabelos, meneios do pescoço, cor dos dentes, forma das unhas - passaram a se agigantar como suscitadores de interesse sexual e passaram a conter em si toda a loquacidade erótica que o moralismo puritano sufocava alhures.

Muito mais além desse limite estritamente corporal, até mesmo os objetos que compunham o ambiente quotidiano poderiam estimular sexualmente em suas minudências, fazendo com que as pessoas que os portassem ou os testemunhassem fossem capazes de se sentir diretamente comprometidas por lembranças ou associações culposas. Foi o caso, nas casas vitorianas, das coberturas das pernas de pianos e mesas, passíveis de sugerir, de forma provocante, os membros femininos correspondentes (Sennett, 1989). Foi também o caso do cuidado de se evitar que objetos evocassem as formas do falo. Talvez tivesse sido também o caso de algumas teorias nascidas mais ou menos nessa época, que, inspiradas na mesma matriz cultural, tentaram entender o psiquismo humano com base em simbolismos sexuais 'inconscientes'. 
Vigarello (1985) deixou bastante evidenciado que o espaço deixado pelos banhos públicos e privados não foi ocupado por um vácuo. No século XVII, havia cuidados corporais que este autor chamou de "higiene seca", forma de cuidado corporal não de todo desaparecida ainda nos dias de hoje, em importantes regiões da Europa. Por meio desta expressão, Vigarello se refere à toilette do homem e da mulher de corte, que esfregavam o rosto com um lenço branco ou com uma toalha, em vez de lavá-lo. Focalizava-se a atenção, nesses tempos, sobre as partes do corpo que se mostravam no teatro social, isto é, fundamentalmente as mãos e a face. A "higiene seca" era uma norma de limpeza da época, em que pese o fato de que possa nos parecer uma regra bastante esdrúxula, em virtude de não mais fazer pleno sentido nos termos de nossa sensibilidade contemporânea.

Nos idos do século XVI, quando os textos tematizavam os odores corporais, referiam-se também à conveniência de eliminá-los. Esfregamentos e perfumes preponderavam sobre banhos ou lavagens: antes de tudo, era preciso enxugar vigorosamente, drenar, secar o corpo. Vigarello sustenta que, nos contextos dos séculos XVI e XVII, não se poderia nem imaginar uma cena de banho pelo fato de alguém receber uma visita, ao passo que até o século $\mathrm{XV}$ as pessoas procurariam banhar-se para dar mais intensidade a suas festas e a seu prazer. Ao mesmo tempo - e talvez paradoxalmente - gastava-se agora muito empenho e capricho no gesto de pentear-se, vestir-se e decidir-se em qual lugar do corpo ou das roupas colocar as jóias. $\mathrm{O}$ uso da água desaparece; mas as preocupações com o corpo crescem de um modo qualitativamente diferente.

"C'est le linge qui lave". Com estas palavras Vigarello procura sintetizar e colocar em evidência o sentido de uma nova atenção à limpeza. Esta se orienta, agora, em particular para as roupas de baixo e para as vestimentas. Em vez de referir-se à pele, dirige-se a este objeto mais imediatamente visível, que é a roupa. A limpeza pessoal passa a ser simbolizada pelos trajes e, muito especialmente, por aquilo que se interpõe entre o corpo e o que se oferece à visão. As roupas de baixo se vêem pouco, é evidente. Não obstante, o ritmo, ou melhor, a freqüência de sua mudança se transforma em importante indicador de limpeza corporal (Vigarello, 1985).

O aumento do hábito de trocar as roupas de baixo assinala 'progressos' na higiene pessoal, seja no plano individual, seja no eixo das modificações históricas e coletivas. Além disso, um conjunto de artifícios vem fazer crescer o jogo entre a superfície e a profundidade das roupas, entre o interior e o exterior do corpo e da pessoa. Materializando aqui um princípio cultural que já pudemos surpreender em diversos outros domínios da experiência, várias peças do vestuário se autonomizam, multiplicando os intermediários visíveis entre os trajes e a pele, ajudando a distanciar o interno do externo corporais. $\mathrm{O}$ fato de que tais peças se manipulassem e se lavassem separadamente revela também a vontade de uma ilusão, como se houvesse a intenção de prolongá-las e de fazer-lhes aumentar a superfície. 
Os novos conceitos se preocupam antes de tudo com a aparência. A atenção que esta teoria da limpeza desenvolve volta-se sobretudo para o olhar e para o olfato. Mudar a roupa de baixo supõe uma sensibilidade que não é puramente a do olhar. Considera-se que substituir periodicamente estas roupas intermediárias fosse limpar a pele. Sua brancura eliminaria o cascão, por efeito de absorção, atingindo a intimidade do corpo ao mesmo tempo em que a protegeria. As conseqüências das mudanças de roupas íntimas seriam comparáveis às da água, embora sem os inconvenientes desta última. Teriam essas roupagens intermediárias um resultado até mesmo muito mais seguro e muito menos perigoso que o da lavagem. Em síntese, com as roupas de baixo, às inquietações que o banho suscitava adicionase agora a certeza da quase completa inutilidade de se banhar.

Mais ainda. Entre a mudança da roupa de baixo e a imersão sempre muito rara, acrescentaram-se gestos, embora de pequena freqüência, que insinuavam o nascimento de uma limpeza localizada e especializada: lavagens de pés ou de assento, fricções suplementares a essas abluções, nas articulações, nas zonas intersticiais do corpo e, sobretudo, naquelas onde a permanência do suor causava risco de produzir mau cheiro. Tudo isso definiu, por volta de 1740-1760, uma espécie de higiene setorial ainda hoje bastante comum nos países europeus, segundo os variados segmentos sociais.

Esta higiene setorial, estreitamente vinculada ao processo de fragmentação a que tantas vezes tenho feito referência, suscitou, por sua vez, uma verdadeira pululância de objetos especializados (pentes, escovas, empoadeiras, perucas, espelhos, toalhas, entre outros), destinados a lidar com as mais diversas partes do corpo. $\mathrm{O}$ bidê - nas origens ainda um móvel trabalhado e adornado com requinte - pode sem dúvida ser considerado um marco cerimonial desse tipo fragmentado de prática de limpeza corporal. No entanto, pelo menos até o início do século XIX, o bidê permaneceu um objeto raríssimo, verdadeira insígnia de distinção social.

As camadas superpostas de roupas, desse modo, são muitíssimo relevantes, pois que destinadas a reter a transpiração, a umidade e as impurezas. A sensação de suor, por sua vez, desempenha papel de importância radical, uma vez que suscita e constitui o fator que decide sobre a necessidade de mudança da roupa de baixo. Fato bastante significativo para os nossos propósitos, o avesso da roupa, que emergira como um detalhe minúsculo, passa, entretanto, a ocupar uma posição historicamente inédita: falar dele, nesses tempos, representa o mesmo que se referir àquilo que este interno da roupa tocava e encobria. $\mathrm{O}$ tratamento dessa roupa de baixo e, principalmente, de seu lado interior transformou-se em signo privilegiado de cuidado com o corpo.

Mediante este tipo de tratamento do corpo definiam-se o grau e a qualdade de atenção ao mesmo, bem como o teor de negligência envolvida. Naquela época, a privação das roupas íntimas ou de sua limpeza e troca correspondiam mais ou menos ao que hoje seria a ausência de abluções (Vigarello, 1985). A limpeza das 
roupas interiores definia, além disso, a direção do processo de higiene corporal: a exemplo do que já pudemos perceber em outros movimentos desse processo, este rumo apontava para a transição do mais visível ao menos visível, do mais exterior ao mais reservado, do mais íntimo ao mais secreto.

O íntimo passou a adquirir, com os hábitos de vestuário e de limpeza das roupas, um lugar que não possuía. Isto porque a mudança de camisa e de roupas de baixo após a transpiração constitui um gesto de si para si, eminentemente. Representa uma auto-avaliação crítica, um julgamento de si. Constitui um ato privado, derivado de uma sensibilidade privada. Significa uma nova orientação dos sentidos, agora direcionados para dentro. Pressupõe uma vigilância de si. Exige uma atenção reflexiva nova. Por intermédio desta, cada um passa a se policiar a si mesmo.

Como conseqüência desses princípios, colarinhos e punhos se transformaram em uma espécie de objetivação do íntimo, a partir do século XV e muito mais intensamente nos séculos XVI e XVII. Agir sobre punhos e colarinhos tornou-se o mesmo que atuar sobre aquilo que metonimicamente representavam. Daí a necessidade crucial e cada vez maior de mantê-los sempre alvos e vistosos. É evidente, no entanto, que este sistema não se implantou de forma súbita. No século $\mathrm{XV}$, era comum que as pessoas tivessem apenas uma camisa e ficassem esperando que ela secasse quando lavada. No inicio do século XVI, segundo os inventários, as camisas ainda eram raras e as trocas resultavam bastante infreqüentes. Mesmo nos meios cortesãos, a substituição de camisa seria cotidiana - se o fosse - talvez apenas no início do século XVII.

Ao lado das vestimentas, os perfumes aparecem como instrumentos desta nova arte da aparência. Destinam-se a uma encenação enganadora que se adiciona e sobrepõe à visibilidade das várias camadas de roupas. Primeiro busca-se saturar os armários de pós perfumados, para que a roupa, inclusive a de baixo, conserve a marca durável de seus aromas. Mas também aparecem os diversos sachês, que devem ser colocados sob as axilas, nos quadris, nas dobras das roupas e do corpo, nos interstícios corporais, nas partes íntimas...

Tais perfumes não são de modo algum uma descoberta do século XVII, já que os inventários dos séculos anteriores eram ricos em enumerá-los, e que eram largamente conhecidos desde a mais profunda Antigüidade. Agora, entretanto, surge uma verdadeira mania de se perfumar, parte fundamental dos artifícios de aparecer. Aflora também uma sensibilidade 'refinada', a separar as fragrâncias que têm esta característica de outras tidas por grosseiras - mas nem por isso inúteis ou indiferentes, como os cheiros exalados pelo alho, pela cebola, vinagre etc.

Para o policiamento e gerenciamento dos odores, uma grande tecnologia logo se desenvolveu. Primeiro, compreensivelmente, um arsenal de base natural, de essências botânicas puras ou combinadas: canela, eucalipto, cravo, limão, alecrim, mangerona, hortelã, louro... Esta tecnologia naturalista dos séculos XVII, 
XVIII e XIX consistiu fundamentalmente de odores vegetais. Ela se opunha radical e explicitamente àquilo que se queria reprimir de modo sempre mais severo, isto é, o odor animal.

Enquanto a química industrial não se manifestava de maneira mais ostensiva, com seus perfumes artificiais e poderosos, tentava-se ao menos fazer a encenação de que os odores não estivessem lá. Ou, mesmo, procurava-se fazer de conta que, domesticados, não ousavam ultrapassar limites. Disso resultava que as pessoas eram incentivadas a usar saquinhos com perfumes, a lavar as roupas, a corrigir os odores da atmosfera individual com exalações que mascarassem as emanações espontâneas do organismo. Acima de tudo, era necessário que fizessem, com obsessão e de modo muito mais que verossímil, a mise-en-scène das novas territorialidades individuais.

Tal tecnologia foi contemporânea do surgimento de toda uma nova e essencial preocupação com o que se chamou de toilette íntima, algo relativamente desconhecido até então. A propósito, seria bastante interessante relembrarmos aqui as advertências formuladas por Montaigne, ainda no século XVI, em seu famosíssimo ensaio Sobre os Odores: é preciso desconfiar dos que usam perfumes agregados ao corpo, pois que podem estar a esconder algum defeito dessa espécie; o melhor odor é a ausência de qualquer odor; é sinal de fedor o bom odor...

Não excluamos a possibilidade - bastante provável, aliás - de que Montaigne estivesse séculos à frente de sua época, neste como em vários outros pontos de sua obra. Todavia, nada nos impede de especular, até para melhor entender o tempo que estamos considerando, sobre o que poderia ser 'ausência de qualquer odor' no momento em que Montaigne escreveu. Arrisco dizer que, em sua época, 'ausência de qualquer odor' significava a presença de uma mistura muito forte de sensações olfativas simultâneas, simultaneidade que terminava por desindividualizá-las.

Talvez residisse neste ponto a razão de Montaigne desconfiar da proeminência e da preeminência de um odor reparável, particular, específico, individualizável. Esta suspeita retornaria mais tarde, no século XX. Mas em nosso século ela encontraria um cenário totalmente diverso, de silêncio olfativo, de rejeição contra os perfumes exagerados, que passaram a ser entendidos e sentidos como agressivos e começaram a depor contra seus portadores. Em nosso tempo, para as nossas sensibilidades (segundo os meios sociais, é óbvio), convém que as fragrâncias agregadas ao corpo sejam estrategicamente discretas, suaves, sutis, nuançadas, matizadas...

De maneira totalmente diversa, naquele momento a que me referia, isto é, nos séculos XVII e XVIII, quando a preocupação era crucialmente com a contenção e a repressão dos cheiros orgânicos, o perfume-antídoto deveria ser violento, sufocante mesmo. Nos meios aristocráticos, todos se perfumavam. Todos se perfumavam da cabeça aos pés. Sobretudo, todos perfumavam as roupas. A idéia de higiene corporal vigorante até o inicio do século XIX, como estamos acompanhando, dizia respeito a trocar de roupas, roupas limpas etc., pois as vestes expressavam por metonímia o corpo a que estavam contíguas. 
Evidentemente, para não andarmos mais rápido do que seria justo, deveríamos também ponderar que os manuais militares de 1769 ainda recomendavam, para expressar o 'progresso' da limpeza, que se fizessem as trocas de roupas uma vez por semana, idealmente. As águas, lembremos sempre, ainda atemorizavam e os médicos continuavam a advertir contra os atos de molhar a cabeça, entrar na água, imaginando haver perigo de congestão cerebral, de infertilidade, de redução da elasticidade da pele e assim por diante. Até mesmo se aconselhava contra o risco da perda daquele verniz, daquela película 'protetora' do corpo, que era nada mais nada menos que o cascão.

Somente nas décadas finais do século XVIII o cascão começaria a se transformar em inimigo a ser combatido com rigor e obsessão. Não nos iludamos, entretanto. $\mathrm{O}$ combate ao cascão não invocava de início quaisquer razões de limpeza: era apenas para que os poros pudessem desentupir e respirar que ele deveria eventual e raramente ser removido. A finalidade dessa remoção era a de que estranhos tumores, pressões internas e inchamentos não se desenvolvessem, provocados pelo abafamento que o cascão poderia provocar ao fechar as saídas do corpo. Ora, de modo bastante coerente esta razão valia apenas para as elites. Não abrangia de forma alguma os trabalhadores braçais, uma vez que esses já transpiravam bastante na labuta, atingindo o mesmo fim por outros meios. Estavam, por conseguinte, dispensados da obrigatoriedade de se lavar, ainda que tal se desse apenas de tempos em tempos.

A limpeza da pele começou a ser vista, assim, como algo que fortalece o organismo. Começou a haver, a partir do século XVIII, uma reação contra os excessos no uso de pós e de pomadas perfumados nos cuidados corporais. Esta nova atitude estava ligada à crença no desequilíbrio de humores, que poderia ser produzido pelo bloqueio dos poros, associado ao desenvolvimento do cascão (Vigarello, 1985). Por essa via, o uso da água foi mudando lentamente, a partir do meio desse século. A água, que abalava a fisiologia e que veiculava energias secretas e perigosas, foi-se transformando de modo gradativo em algo mais funcional e foi encontrando outras legitimidades. Por exemplo, servia agora para proteger, para propiciar saúde ou vigor. Este ponto foi crucial, pois a limpeza corporal não poderia ter mudado de sentido e não conseguiria ter tomado a direção que viemos a conhecer sem que as antigas idéias sobre a água se tivessem transformado.

Trata-se, como estamos vendo, de uma limpeza totalmente nova, em princípio destinada aos privilegiados. Esta nova limpeza permanece por muito tempo apenas alusiva e bastante confusa. Teoricamente, trocar a roupa de baixo para combater a umidade produzida pela sudação não é mais o único gesto eficaz para cuidar da pele. No final do século XVIII, o banho começou a ter uma presença mais ativa. No entanto, isto não quer dizer que se tivesse tornado familiar. Nem mesmo significa de modo cabal que a limpeza já fosse explicitamente o objeto do ato de banhar-se. 
O fato é que com estas novas idéias sobre a água, as abluções pouco a pouco iam-se instalando. A água se integra em novos circuitos. A imersão, até então raríssima, começava a ser aceita de novo. Esta acolhida principia em uma elite, embora sem sentido propriamente higiênico, pois continuará mais ligada à terapêutica e às regras de decoro e cortesia. Por muito tempo ainda - rigorosamente até nossos dias, conforme os países e as classes sociais - inexistirá uma gramática da higiene 'líquida'. Por esta razão, cada um poderá ter a sua própria norma para o banho (Vigarello, 1985): alguns o tomam de oito em oito dias; outros, de dez em dez; outros ainda, a cada mês; muitos, a cada ano....

Aos poucos, talvez como tivesse pressentido Montaigne, foi-se firmando o conceito de que, sendo um simples efeito de superfície, os perfumes poderiam no máximo enganar. Além daqueles que levantavam argumentos de ordem médica contra a ação deletéria de pós e pomadas odorantes, começavam a se multiplicar os críticos que acreditavam que a melhor resposta aos aromas orgânicos fosse pura e simplesmente o ataque e a supressão das fontes de mau odor (Vigarello, 1985). Eis aí o contexto em que o sabão surgiu, brandindo nesse palco o seu poder de apagar e dissolver o cascão, alardeando a sua capacidade de purificação radical. O sabão não era um simples cosmético. Não era mais, como a parafernália anterior de lidar com o corpo, um mero instrumento de cortesia e de teatralidade social. O sabão era agora um detergente. Um eliminador de gorduras, de suores e sujeiras. Um erradicador. Instrumento de higiene, enfim.

Para muitos, sem embargo, a água continuava a ser perigosa durante o século XIX, pelos mesmos motivos de sempre: porque se difundia e penetrava nos corpos, porque abria os poros e permitia que o ar penetrasse no organismo... Prudências se impunham, em muitos casos, como uma espécie de compensação às novas concessões feitas ao banho. Refiro-me a cuidados ainda não de todo desaparecidos em nossos dias, tais como purgações para impedir que a infiltração da água se adicionasse à repleção alimentar, leito e repouso em seguida às imersões para evitar o cansaço...

Portanto, não foi sem enfrentar resistência que o banho se difundiu. Mesmo no interior das elites aristocrática e burguesa, que foi onde o movimento em favor do banho começou a ganhar sua nova força, a imersão permaneceu rara. Em 1750, Blondel, em seu trabalho L'Architecture Française (apud Vigarello, 1985) contou, em setenta e três mansões de Paris, apenas cinco com cômodos especificamente destinados ao banho. Além disso, não se pode dizer que a freqüentação desse cômodo, quando existia, fosse regular. Até 1880 é impossível imaginar um banho cotidiano, a não ser por recomendação médica.

Em compensação, por volta de 1840 quase todas as mansões seriam dotadas de cabines ou de salas especializadas para a encenação do ritual do banho (Vigarello, 1985). Tais lugares constituíam espaços destinados ao desnudamento 
do corpo, para fins de uma toilette que logo dispensaria, por razões de pudor, a presença dos criados de quarto (Perrot, 1991). Nesses templos enfatizava-se principalmente o culto aos limites interiores e exteriores de si mesmo. Tais cômodos destinados ao banhar-se, assim como seus equipamentos e os gestos que suscitavam, eram normalmente de origem inglesa e se difundiram efetivamente pela Europa a partir das últimas décadas do século XIX e das primeiras do século XX. Eles materializavam o rompimento com as antigas tradições populares, no sentido e na direção que esta ruptura tem de mais marcante: o fechamento de cada ser humano aos outros e, mesmo, a si.

O desenvolvimento de uma aparelhagem técnica específica veio auxiliar a normatização e a padronização das atividades corporais. Ajudou também a definir a territorialização do corpo em ambientes mais reservados, discretos e especializados. Isto não significa, no entanto, que o aumento do limiar de vergonha e a maior dramaticidade das fronteiras de repugnância com respeito a si e aos outros possam ser atribuídos a quaisquer das inovações técnicas - tomadas isoladamente ou mesmo consideradas em conjunto. As transformações da sensibilidade não se deveram em absoluto aos progressos da tecnologia (pias, bidês, banheiras, chuveiros, água encanada etc.), nem ao avanço das descobertas científicas - como muitas vezes somos levados a acreditar, influenciados por uma cultura que mistifica a técnica e a racionalidade. Nesses 'progressos', há muito menos de racional do que habitualmente somos convidados a supor.

A rigor, o contrário é que parece verdadeiro, aliás. Essa parafernália técnica e ritual provavelmente teria sido expressão dramática e emocional do enclausuramento de cada um em si e da obstrução de si a si próprio. O 'íntimo' nasceu e se desenvolveu como uma dimensão de si proibida aos outros. Mas também como algo interditado a si - por mais paradoxal que isso possa parecer. Para retomar uma imagem já utilizada, o crescimento do íntimo é como a diminuição do diâmetro de um círculo: quanto mais possuo esse íntimo, mais ele foge de mim. Cada um, desde criança, internaliza gradualmente a obrigação de se banhar e de se limpar, mesmo quando outros não estão presentes para castigar ou criticar. Aos poucos o controle efetuado sobre si através de terceiros vai-se convertendo em autocontrole e autovigilância. Deste modo, o eu se transforma em cárcere cada vez mais exíguo. E cada um, em carcereiro sempre mais severo de si mesmo.

Com o auxílio dos novos meios técnicos, as manifestações mais ligadas ao fato de o homem ser um corpo passaram a ser mais eficientemente excluídas. Excluídas não apenas da vida coletiva, mas da convivência de cada um consigo próprio. A vergonha e o asco, a elas associados em público, insensivelmente se transferiram também ao âmbito do privado, do íntimo, do secreto. Inspirada pela repugnância, junto com uma tecnologia que distanciou meu corpo dos de outrem, desenvolveu-se igualmente uma que o afastou de mim mesmo. Nada a estranhar, por conseguinte, que - por repressão de pensamentos, visões, cheiros, tatos, sons e tudo o mais - se acabasse por quase proibir qualquer relação mais próxima 
de cada um consigo mesmo. Nada há de incompreensível no fato de que ulteriormente, de modo predominante em certos meios sociais (com exclusão praticamente total de outros), este rio, em determinado momento de seu curso, viesse a desaguar em um mar que pôde ser apelidado de 'insconciente'...

A partir das décadas centrais do século XIX, as autoridades das cidades começam a projetar, a propiciar ou a exigir a construção de locais públicos para banhos e lavagens destinados aos trabalhadores. Esta categoria social estava associada simbolicamente à natureza, o que fazia dela, além de um contingente humano votado a ser 'explorado', uma fonte de perigo de poluição. Os novos locais de lavagens são espaços a que, em teoria, os pobres poderiam ou mesmo deveriam comparecer, para se purificar gratuitamente ou a preços bastante reduzidos (Vigarello, 1985). O asseio 'pessoal' dos pobres se transformou, ao menos do ponto de vista teórico, em assunto coletivo, em questão de higiene e saúde públicas, em problema de profilaxia urbana.

Claro está que estes novos estabelecimentos nada conservavam da inspiração das termas do passado medieval. Eram utilitários, nada festivos. Os banhos tinham duração predeterminada, estavam submetidos a regras estritas, que previam até a temperatura, a força dos jatos, o tempo e a quantidade de liberação da água... A imersão se encontrava banida, pois era considerada demorada e enfraquecedora, passando agora a ser substituída por chuveiradas, tidas como mais rápidas e tonificantes. Nada dessa higienização dos pobres escapava ao novo espírito do tempo: embutida na limpeza e nos banhos dos segmentos desprivilegiados, podemos tranqüilamente descobrir uma pedagogia da ordem e uma ética do trabalho. Também encontramos uma lógica de rentabilidade, que quer, como em tantos outros domínios da existência, simplesmente lavar o maior número de pobres com o menor dispêndio de tempo e de recursos.

Existe, pois, uma história de nossa higiene pessoal, muito mais recente do que de hábito se imagina. Somente aos poucos, muito aos poucos, é que se foi formando a idéia de que limpeza física constituísse também limpeza moral. O pensamento que associava sujeira pessoal e sujidade moral não nasceu socialmente antes do fim do século XVIII. A partir desse momento, contudo, os seres bem-apessoados, os homens limpos, banhados, penteados, os indivíduos atentos aos detalhes de seus corpos começaram, de modo cada vez mais intenso e sofisticado, a ser considerados também como pessoas confiáveis e aproximáveis, como gente com quem fosse possível fazer amizade, como seres a quem se pudessem abrir as portas, com quem fosse admissível partilhar refeições, casar, negociar...

Em razão dos desdobramentos dessa história, estamos hoje fadados a reagir visceralmente, com asco mesmo, contra aqueles que discrepem dos ditames desta sensibilidade. A macropolítica das classes sociais acaba por penetrar no mi- 
croscópico de nossos órgãos, de nossos músculos e de nossos sistemas nervosos. Entre esses aconteceres há defasagens temporais tão pequenas, que muito provavelmente redundam em coincidência: se, por um lado, o sentimento de que a sujidade física e a poluição moral impliquem uma na outra não emergiu antes do final do século XVIII, por outro, a idéia correlativa de que os pobres fossem fisicamente sujos não se firmou socialmente antes do início do século XIX.

Ainda mais, tal conceito apareceu junto com a opinião de que os trabalhadores precisassem ser desodorizados, disciplinados, localizados, para o bem deles próprios. Evidentemente é preciso considerar que semelhantes pensamentos, vontades e projetos não são de modo algum neutros do ponto de vista político. Estes sentimentos/teorias não são desinteressados, nem são movidos tão-somente por altos valores inspirados pelo altruísmo e pela abnegação. Tampouco são incitados apenas pela ética, à primeira vista generosa, de quem sinceramente pretende levar ao outro aquilo que pensa ser bom para si.

Não. Esta idéia está associada de modo complementar à que permitiu aos burgueses confinarem os pobres, impedindo-os de circular livremente pelo território urbano. Em sua base figura o pensamento que os acusou de serem transmissores de epidemias e portadores de morbidez. Mais ainda, este modo de ver as coisas não se limitou a servir de justificativa, sob a capa da neutralidade, para separar os pobres, para os espacializar e desodorizar. Serviu também para definir os tratamentos específicos a que doravante deveriam ser submetidos aqueles representantes da pobreza que, por conveniência das elites, freqüentassem como trabalhadores os ambientes dessas últimas: por exemplo, porteiros, amas, copeiras, cozinheiras, carteiros, entregadores, jardineiros, faxineiros.

Tais pessoas passaram a ser vistas como seres especial e perigosamente ambíguos. Sobre estes trabalhadores, desse momento em diante, foi possível recaírem os mais dolorosos preconceitos, estigmas derivados do fato ameaçador de elas colocarem em contato os domínios da riqueza e da pobreza. Tais discriminações nem sempre foram perceptíveis ou questionáveis, uma vez que foram previamente racionalizadas e absolvidas pelo argumento e pelo disfarce da 'higiene' base sobre a qual se estruturou um discurso insidioso, embora concebido como se pairasse acima de qualquer questionamento.

Por esta via, entende-se que coisas aparentemente tão ingênuas, inofensivas, 'racionais' e 'funcionais', como os aventais das cozinheiras e arrumadeiras, os uniformes dos garçons, com seus colarinhos e punhos alvos e vistosos (mesmo que muitas vezes inexistam as camisas cujas extremidades eles simulam ser), as luvas dos mordomos, as toucas das babás, os bonés e chapéus de padeiros e entregadores, as unhas polidas dos barbeiros... acabassem tendo uma função ritual e significante implícita e inconfessada, terminando como instrumentos simbólicos de marcação de distanciamento e de separação sociais. Semelhantes equipamentos materializaram a capilarização da higiene e a microscopização dos cuida- 
dos corporais, por um lado. Por outro, sobretudo, concretizaram gravíssimas suspeitas, ainda que com freqüência sutis e discretas, contra todas as categorias sociais do tipo mencionado.

Este quadro de temores se agravou especialmente após o advento das descobertas de Pasteur, como já registramos algumas páginas atrás. Sob a inspiração dessas novas teorias, a higiene, em razoável medida, tornou-se uma espécie de guerra de extermínio contra o micróbio. Poderíamos especular se a idéia de extermínio era passível de formulação nos quadros cognitivos medievais, dado que nestes tudo era vida. Mas foi invocando uma assepsia microbiana radical e profunda que os primeiros manuais da era pasteuriana passaram de início a recomendar um banho por semana, especificamente para os doentes de hospital.

Particularmente interessante é reparar que as experiências médicas sobre o asseio corporal foram feitas antes de tudo - e com muito cuidado - nos hospitais, nas prisões, nos hospícios, nos asilos e nos navios. Estes territórios fechados eram habitualmente vistos como os lugares da sujeira por excelência. Além disso, eram também considerados espaços habitados por seres 'irresponsáveis', como loucos, doentes ou criminosos. Exatamente por causa desta irresponsabilidade, tais pessoas estavam desqualificadas o suficiente para serem objeto desses ensaios de higiene corporal, cujos efeitos e riscos na época era impossível avaliar. A higienização dos loucos, dos presos, dos banidos, foi um passo na direção da implantação de uma nova ordem. Fazia já algum tempo, como sabemos, que os colégios tinham começado a seqüestrar as crianças para, entre outras coisas, ensinarem-nas a serem 'limpas' e para fazer delas instrumentos dóceis de reprodução e de multiplicação da nova sensibilidade corporal (Ariès, 1978; Foucault, 1975).

O universo bacteriológico que Pasteur revelou veio a modificar inteiramente a imagem da utilização da lavagem, tornando-a mais assimilável pelas antigas teorias. Os seres corpusculares ínfimos se transformaram em poderosíssimos monstros invisíveis, igualmente capazes de atravessar todas as barreiras, materiais, corporais ou sociais. Estes seres invisíveis puderam, desse modo, ser compatíveis, associar-se e harmonizar-se bastante bem com as imagens antigas de um organismo atravessado por fluidos. Os micróbios continuavam a insistir sobre a fragilidade da superfície corporal e sobre a vulnerabilidade de seus orifícios. Por essas razões, as teorias pasteurianas e seus microorganismos patogênicos não foram vistos como algo a repelir de imediato; ao contrário, encontraram, ao menos sob esses aspectos, uma localização mais ou menos cômoda no âmbito das concepções já existentes.

Além do mais - e isto deve ser vivamente ressaltado -, os pressupostos sociológicos da discriminação independeram dessas descobertas. Eles já existiam havia algum tempo no cenário urbano, como tivemos oportunidade de acompanhar, e foram o resultado de um movimento cuja direção já era bastante conhecida: do público para o privado, do privado para o íntimo, do íntimo para o secreto, do visível para o invisível, do consciente para o inconsciente... Na marcha do 
macroscópico ao microscópico, a novidade que aconteceu - reiteremos - foi a espécie de fundamentação 'objetiva' que as novas teorias microbianas pareceram vir a oferecer de bandeja a um projeto preexistente. Doravante, o perigo será algo que reside 'lá'. Constituirá uma coisa que existe de fato. Representará uma ameaça que, em princípio, independe da vontade humana, mas que poderá vir a ser controlada pela ação desta - ou, ainda, incrementada por sua omissão.

A partir desse ponto, a discriminação do espaço urbano e as técnicas de desinfecção receberam quase automaticamente uma justificativa 'desculpabilizadora'. Passaram a se beneficiar do próprio ser das coisas. A lógica de cientificidade contida nas teorias pasteurianas, bem como o êxito das experiências feitas sobre os seres 'irresponsáveis' foram socialmente absorvidos, de modo a tornarem a separação espacial das classes em algo 'necessário', que deveria ser desideologizado, que constituía um bem em si e que deveria, por tais motivos, pairar acima de vontades e interesses setoriais.

Por este caminho, a necessidade de lavar e de limpar os pobres tornou-se de 'bom senso'. Transformou-se em um lugar-comum, dispensando discussões. Desinfetar os pobres passou a ser uma conquista óbvia de todos, principalmente dos próprios pobres. Todos os espíritos 'esclarecidos' e 'bem-intencionados', unânime e pacificamente, não podem deixar de com ela concordar... Como Bourdieu observou, a distinção social ganha em eficácia sobretudo quando fundada em diferenças 'objetivas' (1982).

Nada haveria, em princípio, a implicar das idéias de democratização da higiene, e tudo isso seria muito fácil de aceitar, se os próprios pobres - desprezando completamente o fato de que isso fosse um projeto das elites burguesas e aristocráticas para os desinfectar - tivessem espontaneamente esquecido as acusações gravíssimas de que eram vítimas e tranqüilamente desejado acolher como suas, como próprias, essas tais 'conquistas'. Tudo seria muito deglutível, se os 'beneficiados' tivessem seguido por vontade própria as trilhas que lhes traçaram as camadas dominantes e, mais tarde, as autonomeadas vanguardas de esquerda. Acontece, entretanto, ironicamente, que não foi desse modo que as coisas se deram. Acontece, além disso, e sobretudo - como a história nos ensinou de maneira muito mais que repetida -, que nem mesmo os estratos privilegiados, aristocráticos ou burgueses, seguiram assim tão espontaneamente as sendas indicadas por esses 'progressos' e por essas 'conquistas' corporais.

Que dizer, então? 


\section{Conclusão}

A história leva a tudo, com a condição de se sair dela.

Lévi-Strauss

Muito dessa política das elites, a que fiz referência nas páginas finais do capítulo anterior, permaneceu como pura intenção. Isto é verdadeiro mesmo que nos situemos apenas no âmbito restrito das camadas dominantes do século que está em vias de terminar. Percorrendo sua paisagem, veremos reiteradamente que, no passado ou na atualidade, as resistências se fizeram sempre presentes. Tais resistências não se deram exclusivamente entre os pobres, o que resulta bastante evidente, em especial se nos dermos ao trabalho de considerar a imensa diversidade de atitudes em relação ao corpo e às novas normas. Dizendo de outro modo, se nos dermos ao trabalho de encará-las segundo as especificidades culturais das diferentes nacionalidades, de acordo com os estratos sociais, observando as regiões geográficas, considerando as religiões, levando em conta a circulação das modas, respeitando os níveis de instrução, prestando atenção às preferências dos indivíduos, das idades e dos sexos, reparando nas variações contextuais, colocando em evidência os níveis e intensidades da adesão a estas atitudes e normas.

Em seus aspectos mais específicos e detalhados, este assunto é muito difícil de tratar, pelo que contém de tabu, de desconhecido, de misturado, de confuso e, particularmente, de inconfessável. Acima de tudo, há uma dificuldade teórica que torna a precisão cirúrgica um problema praticamente intransponível nesta questão, pois entre a lei e a transgressão da lei existe profunda e estrutural cumplicidade. Presente, passado e futuro coabitam de modo tenso por toda parte neste campo. Assim, ao lado das modernas concepções alardeadas pelos anúncios de produtos de higiene, apresentando com freqüência uma visão futurista do corpo e de seu tratamento, ainda é possível (e talvez de modo crescente) encontrar os que ainda o vêem ligado à ordem cósmica, vegetal e animal e que o compreendem por suas relações simbólico-alegóricas com as fases da lua ou com a importância mágica das extremidades corporais. Não raramente, concepções contraditórias coexistem nas mesmas pessoas. 
Também é possível encontrar, mesmo no interior da burguesia - onde cedo as crianças aprendem a sentir como algo vergonhoso uma pequena mancha ou um mínimo rasgo em suas roupas -, aqueles que não sentem assim tanto desprezo pela carne não asseptizada e que associam valor erótico e excitante exatamente às violações dos novos preceitos, atribuindo ao proibido uma dimensão fundamental de satisfação e fazendo de odores, secreções, visões escancaradas do íntimo... alguma coisa secreta e inconfessavelmente desejável. A respeito dos 'progressos' da higiene e do tratamento do corpo é preciso, portanto, muita prudência, qualquer que seja o meio social considerado. Suspeitas e decepções estarão à espreita do analista que generalize sem cuidado. Além disso, cruéis preconceitos poderão guiar seu raciocínio ao generalizar.

De um ponto de vista genérico, sabemos com alguma certeza que os princípios dos novos cuidados corporais deslizam aos poucos, com o tempo, das classes superiores para as camadas médias, e daí para os estratos populares das cidades e dos campos. Não perdendo de vista a posição específica dos vários grupos e culturas, nas regiões que foram colonizadas, igualmente, os padrões ocidentais se estão disseminando de cima para baixo e mesmo (ainda que muito raramente) de baixo para cima na hierarquia social - se esta imagem espacial da sociedade não obscurece o entendimento mais do que o favorece.

Estes movimentos normalmente têm como objetivo 'aburguesar' a sensibilidade operária, popular ou nativa, dentro do que for possível, fazendo recurso à modulação dos seus ímpetos de transbordamento, visando ao refinamento de seus sentimentos e à disciplinarização de suas formas de conduta. Esta vontade de aburguesar é compreensível, na medida que acompanha quase sempre a expansão do sistema capitalista e industrial. Afinal de contas, a divisão do trabalho exige incremento do controle sobre a coordenação de atividades dos variadíssimos grupos e pessoas envolvidos no processo de produção, pressupondo - para bastante além do mito e da ideologia da democratização - muita disciplina e extrema contenção de cada um.

Por sua vez, esta necessidade de coordenação resulta na multiplicação dos chefes e das hierarquias, visando a combinar os muitíssimos trabalhos parciais. Não é à toa que um dos primeiros maquinismos a se generalizar foi exatamente o relógio, instrumento indispensável para a sincronização dos gestos de grandes massas de pessoas e para a orquestração dos movimentos de multidões de máquinas. O sentido geral deste processo é que "a disciplina magnifica as forças do corpo (em termos econômicos de utilidade) e diminui essas mesmas forças (em termos políticos de obediência)", como Michel Foucault argutamente ressaltou (1975:140).

É preciso ainda chamar a atenção para um ponto extremamente significativo, coerente com estas observações. Neste sistema econômico, as máquinas representam um capital extremamente valioso, depositado nas mãos dos trabalhadores. Esta é uma razão, bastante ponderável, pela qual tornou-se imprescindível 
que os operários fossem disciplinados, que fossem contidos, e que a descontração que caracterizou as camadas populares desde tempos imemoriais passasse a ser rigorosamente combatida. Tais cuidados constituíram necessidade, aos olhos capitalistas, com o fito de evitar que o relaxamento dos trabalhadores viesse a acarretar prejuízos materiais para os patrões (Foucault, 1975).

Não se deve esquecer, por um lado, que muitas vezes há uma decisão mais ou menos deliberada de excluir pessoas e grupos dos signos de respeitabilidade que o novo estilo corporal representa. Afinal de contas, a função básica destes signos é a distinção social, bem como a ritualização de uma hierarquia o que faz deles uma prerrogativa e um privilégio em princípio relativamente restritos, como tivemos a oportunidade de ver. Mas as coisas não são tão simples, pois, às vezes, tendo por base interesses específicos, como os que acabei de mencionar, acontece de se pretender 'democratizá-los', impondo-os de certa forma às camadas populares.

Por outro lado, é preciso colocar vivamente em destaque que nem sempre estão presentes, nas populações ditas 'carentes', a intenção de conquistar prestígio, a veleidade de se distinguir dos outros e, sobretudo, o desejo de se permitir amarrar por autolimitações e por tabus distanciadores. Em outras palavras, diante das autolimitações e dos tabus específicos, que são a contrapartida existencial destes modernos modos de ser, não é de modo nenhum automático ou seguro que os recentes cuidados corporais encontrem imediata adesão nas camadas populares. É ainda menos garantido que, autêntica e espontaneamente, haja aí sincera identificação com os valores que tais cuidados transportam.

Por exemplo, na França, durante muitos decênios, as camadas populares foram expressamente excluídas dos novos modos de comportamento e dos novos cuidados corporais, exatamente para assinalar de forma simbólica sua posição na sociedade. Porém, nos anos 50 de nosso século, incrementou-se naquele país uma política de transferência de famílias populares para moradias dotadas de 'confortos modernos', ou seja, para residências mais ou menos parecidas com as que as elites e a pequena burguesia já conheciam. No entanto, nesses conjuntos habitacionais, foi comum que se guardasse carvão ou que se criassem coelhos nas banheiras: é que, do ponto de vista dos moradores, a função higiênica que tais aparelhos deveriam desempenhar ainda não fazia um sentido que valesse a pena incorporar. E não o fez até que professores, assistentes sociais, publicitários, além de outros missionários da modernidade, tivessem realizado com êxito os seus respectivos serviços.

Mesmo algo tão elementar como o papel higiênico apareceu apenas no século XVIII e demorou muitíssimo a se difundir social e geograficamente. Uma pesquisa de 1951 revelou que $25 \%$ das mulheres francesas entrevistadas nunca haviam escovado os dentes e que 39\% faziam uma higiene completa por mês (Prost, 1992). Ora, números desse teor, assim concentrados, como deixam livres 
as especulações sobre cifras mais diluídas! Quantas seriam, por exemplo, as mulheres que escovaram os dentes apenas uma vez na vida? E as que faziam três higienes inteiras a cada dois meses?

Em 1980, 80\% das casas francesas já possuíam um cômodo com banheira ou um banheiro com chuveiro (Vincent, 1992). Todavia, o consumo de sabonetes era ainda de 2,25 anuais per capita, e havia não mais do que uma escova de dentes para cada três habitantes... Uma enquete divulgada por um semanário parisiense de ampla circulação, em maio de 1996 , estimou que $28 \%$ das mulheres francesas, demonstrando serem bem mais asseadas do que seus patrícios, tomavam banho diariamente no inverno e que $50 \%$ delas faziam o mesmo no verão. A matéria jornalística calculou também que $52 \%$ dos franceses costumavam usar desodorantes e que o consumo per capita de sabonetes havia progredido - para pouco mais do que cinco por ano... Não é implausível imaginar que, para o conjunto da população, bem como para cada pessoa em particular, algarismos como os que acabo de mencionar insinuem um quadro no qual pareceria existir uma espécie de irredutibilidade das sensibilidades 'bárbaras' e 'pagãs' à cultura católica e burguesa. Isto ainda hoje. E muitas vezes vigorando como a parte submersa de um iceberg.

Semelhantes cifras evidenciam claramente que não é possível estabelecer com facilidade cortes bem delineados a respeito de quem é quem em relação à assimilação dos modernos cuidados corporais. Os números mencionados sugerem que esta discriminação constitui uma tarefa muito complicada, mesmo em um país à primeira vista bem adentrado na modernidade capitalista, industrial e de consumo. Uma coisa, não obstante, é bastante segura e possivelmente generalizável para todo o Ocidente: ao contrário do que muitas vezes se pensa, o moderno culto ao corpo tem sido obra muito mais dos comerciantes que dos higienistas. Exemplo: enquanto, em 1979, pronunciando-se em tom grave, as autoridades de saúde repetiam insistentemente em Paris, nos mais diversificados horários dos meios de comunicação eletrônica, "vos dents sont vivantes, pensez à les brosser" ("seus dentes são vivos, cuidem de os escovar"), os outdoors dos comerciantes, com o objetivo de vender toalhas, saudavam com leveza e alegria a chegada do verão, ainda que de maneira um tanto surpreendente, em se tratando de uma das mais 'civilizadas' capitais do Ocidente industrial: "voici la saison des bains" ("eis a estação dos banhos").

A tendência de deslizamento entre classes sociais, a que me referia, representa um movimento apenas estatístico. Precisamos considerá-la nessa dimensão, tendo sempre em mente que esta inclinação é passível de ser constantemente desmentida pelos casos individuais e pelas especificidades culturais. Aqui e ali, nos segmentos elevados, ainda podem preponderar as lavagens fragmentadas: por exemplo, cuida-se com alguma freqüência das mãos, do rosto e dos dentes; enxáguam-se os pés com assiduidade menor; raramente, a cabeça. Enquanto isso, o desejo de aparecer bem socialmente e a busca de afirmação 
social podem perfeitamente levar pessoas, de classes em tese distantes da burguesia, a se banhar ou perfumar com muito mais assiduidade do que as generalizações sociológicas nos autorizariam imaginar.

Nas páginas precedentes procurei tornar claro que é possível uma compreensão dos processos sociais que se apóie na inteligência do corpo e, sobretudo, na sensorialidade. Tentei também ilustrar a outra face dessa moeda, isto é, mostrar que uma compreensão dos modos de sentir só é factível com base na consideração dos processos corporais como fenômenos sociais. A vida coletiva é possível de se captar por intermédio dos empregos que os homens fazem de seus ouvidos, narizes, olhos, bocas, peles... Mas, ao mesmo tempo, esses órgãos e os sentidos correspondentes não existem de modo meramente orgânico, como absolutos a-históricos, devendo sempre ser considerados no âmbito da trama de relações sociais que lhes atribuem sentido.

O eixo fundamental de nosso raciocínio foi insistir sobre o fato de que uma sociedade só encontra existência nos corpos pulsantes dos seres humanos que a constituem: ela é vísceras, nervos, sentidos, neurônios... A história, desta maneira, não se concretiza apenas em guerras, decretos, tratados, obras, monumentos ou entronizações: materializa-se também - e talvez até primordialmente - em perfumes, sons, miragens, memórias, carícias, distâncias, ascos, evitações, esquecimentos... Não há outra concretude social: uma sociedade estará nos corpos de seus membros ou não residirá em parte alguma.

Concebida a sociedade deste modo, a história será sempre, de algum modo, a história do sensível. E esta nos ensinou, sobretudo, que foi somente em tempos muito recentes que se tornou possível imaginar que o mundo fosse pensável tomando-se como ponto de referência o ser humano isolado e fazendo-se abstração de seus contextos sociais. Ela nos ensinou ainda que este próprio ser humano 'isolado' nunca foi soberano e nunca pôde ser efetivamente isolável de suas relações com os outros. Com ela pudemos aprender inclusive que a ficção do ser humano isolado foi historicamente constituída no âmago de um complexo de relações sociais: foi uma invenção cultural. Essa noção representou um artifício psicológico e político, que se constituiu historicamente, não apenas como idéia, mas também como prática de relacionamento social.

Uma psicologia, no sentido corrente da palavra, é coisa de cogitação extraordinariamente recente. Semelhante idéia, em grande medida, foi impensável na maioria das culturas e durante a maior parte do período a que estamos nos referindo. Não obstante, hoje ela é pedra angular de nossas práticas cotidianas, de nossas pedagogias, de nossas políticas, de nossas filosofias, concepções artísticas... Sem esta noção, nossos saberes certamente não seriam o que são e desabariam. Mas caberia perguntar: esta jovem idéia, tão importante para as mentalidades e sensibilidades das elites do poder e do saber contemporâneos, até que ponto terá conseguido penetrar - e com que intensidade - em outros segmentos da sociedade ocidental? 
A constituição da individualidade representou - como tivemos a oportunidade de ilustrar por caminhos os mais diversos - uma mudança radical na conduta, nos modos de pensar e nos sentimentos humanos. Essas transformações se deram fundamentalmente em uma direção muito específica, conveniente a um determinado sistema social e político. Em medida bastante considerável, a reorganização dos relacionamentos humanos que permitiu o surgimento disto que chamamos de indivíduo não aconteceu de repente, nem com facilidade. Ao contrário, fez-se acompanhar da estruturação antropológica de um tipo muito particular de homem, do esculpir, em rocha muito resistente e duríssima, de um ser humano dificilmente encontrável alhures.

O resultado, ao menos provisório, dessa escultura foi a nossa maneira contemporânea de entender e de sentir o que seja 'humano'; de vivenciar, para nós mesmos, a nossa própria humanidade; de nos relacionar, em decorrência, com os outros e conosco mesmos. Derivou daí a tendência atual de não considerar como (ou como menos) humano tudo o que discrepar desse nosso modo de definir o que seja 'homem'. Como a história nos ensinou, uma das marcas fundamentais da construção desse conceito do ser humano que somos reside no autocontrole corporal, afetivo e cognitivo, assim como no crescimento correlativo do espaço privado.

A característica básica deste conceito de ser humano é o espelhamento de si em si mesmo. É o cuidado de si, o olhar voltado sobre si, para dentro de si. É a atenção e o policiamento dos próprios gestos e pensamentos. É o trabalho constante, infatigável e sempre mais aplicado das relações entre o íntimo e o social, entre o cultural e o natural. Mediante esse trabalho, os últimos termos (social, cultural, natural) definham e, ao menos imaginariamente, acabam tendo sua importância sufocada pela indiferença a qualquer paisagem exterior - indiferença gerada no âmago dessa cega viagem que o eu faz de si a si mesmo, que faço de mim a mim mesmo.

Entretanto, e de maneira paradoxal, este culto do eu a si próprio exige um peso progressivo e cada vez mais agressivo das convenções sociais e das artificialidades teatrais sobre o mundo das sensações imediatas e espontâneas. Dito de outro modo: o indivíduo independente, autônomo e livre, absorve água quando pensa respirar e acaba se afogando no oceano das regras de um sistema político e econômico, de uma cultura, enfim, que o escraviza e que o obriga a ser exatamente assim: alguém que desempenha compulsoriamente o papel de ser livre, autônomo, independente...

Semelhante ilusão ocorre porque tudo isso pertence, por excelência, à ordem do imaginário. Tais idéias constituem o cerne do imaginário no sistema capitalista. Do mesmo modo como em nossa sociedade de consumo, baseada na 'livre-concorrência' e na 'liberdade de opções', ninguém é tão livre que possa decidir por não optar, na sociedade burguesa, fundada na 'liberdade individual', nenhum ser humano é livre o suficiente para se considerar 'não livre'. O indivíduo acaba por sentir em si o mal-estar silencioso, derivado da talvez mais hermética 
das prisões, aquela que se constitui quando o homem passa a ser um carcereiro de si próprio, vivendo na ilusão de ser livre. Mal-estar ruminante, que emerge inapelavelmente quando o ser humano se transforma, para relembrar as muito sábias palavras de Montaigne, em "amo de si mesmo".

Ressaltemos, entretanto, como temos feito reiteradamente ao longo dessas páginas, que o divórcio que se pretendeu estabelecer, no Ocidente, entre o homem e ele mesmo, entre o homem e seu corpo, nunca foi absorvido sem rebeldia. Os rituais de obscurecimento da corporalidade, tão característicos dos tempos modernos, dependeram sempre da transformação em poeira de culturas populares de tipo comunitário. Acontece que esta redução nunca chegou a ser completa, nem mesmo nos meios ditos não populares. $\mathrm{E}$ - excetuando-se talvez um exagerado apego às teorias de pendor evolucionista - nada indica irrefutavelmente que um dia poderá ver a luz, seja no Terceiro Mundo, seja mesmo na Europa ou na América do Norte.

Isto significa que - apesar de ter sido desqualificado, de certo modo, desde a ascensão dos burgueses, apesar de ter sido desprezado por todos os meios, apesar de ter sofrido todos os ataques, desde os mais violentos até os mais sutis e refinados - o corpo conservou sempre um lugar central, especialmente na visão de mundo dos segmentos sociais e psicológicos menos atingidos pelos missionários da sociedade capitalista e industrial. Contra tudo o que se lhe opôs, mesmo nos setores em que esses doutrinadores foram mais bem sucedidos, o corpo continuou a ser um ponto crucial de enraizamento dos seres humanos no mundo físico ou comunitário.

Continuou a sê-lo, ainda que este ponto de inserção se limitasse muitas vezes a materializar (disposição, força, resistência etc.) a importância dada pela burguesia às idéias de trabalho e produção, de acumulação e poupança - em um primeiro momento da história capitalista. Continuou a sê-lo, mesmo que negativamente, quando o moralismo puritano o encarou como aquilo que condenava o homem à perdição eterna - em um outro instante. Continuou a sê-lo, ainda quando - as preocupações tendo-se tornado o consumo e o dispêndio de energias - o indivíduo foi 'liberado' como força de trabalho. Neste momento, que é precisamente o nosso, a inserção do corpo no mundo se cristaliza em uma frívola teatralidade narcisista, em que o corpo passa a significar não mais do que um espelho, no qual um 'eu' interior se exterioriza, para enxergar no mundo a única imagem (boa saúde, boa forma, bela apresentação) que lhe interessa contemplar: seu próprio reflexo a interiorizar.

Desenha-se, deste modo, nas décadas que presenciamos, o seguinte panorama: coexistem duas maneiras de encarar o corpo. Elas se antagonizam e ao mesmo tempo se mesclam. Uma, que o deprecia, ainda que tenha recebido às vezes as denominações, em parte ilusórias, de 'culto ao corpo', ou de 'corpo liberado'. Ela o põe à distância, caracteriza o corpo como diferente do ser humano 
que ele encarna e faz dele algo que se possui, como um objeto exterior. Ela concebe o corpo como algo que se produz, como uma coisa ou representação: um corpo que se pode vender e comprar, como bem ilustra o comércio de órgãos, cada vez mais próspero. Para este modo de ver, trata-se basicamente de 'ter' um corpo. Ter 'um' corpo, necessariamente no singular. Ter aquilo que dá contorno a uma individualidade. 'Possuir' aquilo que me separa dos outros, do mundo e de mim mesmo.

No extremo - e isto será facílimo de compreender -, esta primeira concepção é totalmente utópica e ingênua. Sua pedra angular é a idéia de que é preciso sempre e cada vez mais insistir severamente sobre os afastamentos, sobre as distâncias, sobre as vigilâncias, sobre os limites corporais, sobre a demarcação nítida e rigorosa das fronteiras do corpo. O essencial dessas atenções é impedir quaisquer transbordamentos, ousadias, excessos ou infiltrações. Daí esta concepção reverberar continuamente na relevância dos rituais higiênicos, uma vez que estes ritos não são outra coisa senão gestos preocupados, quase obsessivamente, com a importância de se coibirem as ameaçadoras impurificações dos limites corporais.

Nesses gestos, que materializam melhor do que tudo esta primeira concepção de corpo, merecem todo cuidado as roupas, as mãos, os pés, os orifícios orgânicos... Tais atenções se concretizam por intermédio de ritos idealmente repetitivos, como devem ser os da higiene corporal: os das trocas e lavagens sucessivas de roupas, os das varreduras e faxinas periódicas. Acontece, no entanto, que os limites e extremidades, não sendo inteiramente nem 'dentro' nem 'fora' do corpo, terminam por ser simbolicamente sujos, quase por definição (Douglas, 1970; Leach, 1978; Rodrigues, 1979). Esta situação estrutural se deve ao fato óbvio e inevitável de que extremidades e limites representam exatamente aquilo por meio do que o 'interior' corporal se comunica - e, de modo inexorável, se mistura - com o 'exterior'.

Dadas essas condições, existe apenas um único meio de alguém se preservar isento de impureza inteiramente, no âmbito desta primeira concepção de corpo. Trata-se de um meio teórico, embora dite enfaticamente um modo efetivo de ser e delineie uma utopia a dar rumo aos passos da existência de quem nela acredite: separar-se, retirar-se de qualquer relação com os outros e com o mundo, ausentar-se. Ocorre que, na prática, este meio é radicalmente impossível, pois alguém que conseguisse fazer tal trabalho de assepsia com cem por cento de eficácia acabaria por se desligar inteiramente da relação com os outros e com o mundo. Isolar-se-ia. Não poderia mais ser.

De certa forma, uma ilustração prefigurativa dessa situação - que o primeiro modo de encarar o corpo delineia de modo extremo - seria o caso do meninobolha. Refiro-me àquela criança que vive envolvida por uma imensa parafernália de desinfecção, protegida de qualquer contágio pelo espaço artificial e científico, que os médicos lhe criaram e que constitui o seu mundo próprio. As fotos e os filmes mostram essa criança sendo pateticamente acariciada pela mãe, através de 
paredes de vidro. Tudo se passa como se o menino crescesse em uma atmosfera extraterrestre, vigiado por microscópios e computadores, que agem como verdadeiros magos encarregados de realizar o exorcismo total dos germes e bactérias que o poderiam impurificar e lhe destruir a vida (Baudrillard, 1990). Caberia, a propósito dessa existência ilustrativa, a seguinte pergunta: afinal, uma vida assim protegida já não seria a morte?

Em casos menos extremos, uma vez que o mundo se reduziu ao indivíduo, continua-se sensível apenas ao que diga respeito a uma individualidade específica. E isto, de forma paradoxal e irônica, depois de se ter historicamente desenvolvido uma sensibilidade tão 'susceptível' e 'refinada' como a nossa. Por esta razão, são possíveis e têm força de convencimento as desculpas e os argumentos extraordinariamente individualistas do tipo "cada um na sua", "não estou nem aí", "dane-se o mundo", "“imagine se isto acontecesse a você ou à sua filha"...

Foi graças a esta sofisticadíssima sensibilidade que pude tantas e tantas vezes ver monges vietnamitas atearem fogo a si mesmos, transformando-se em labaredas de protesto contra a invasão de sua terra, sem que estas cenas do noticiário da televisão alterassem radicalmente o sabor de meu jantar. Semelhante tolerância eu não conseguia manifestar, nem de longe, com relação a um companheiro de mesa, meu colega de faculdade, que costumava fazer barulho ao mastigar. Por este caminho, em um tempo de tanta 'micro-sensibilidade', foi possível, em cada um de nós, tamanha 'macro-insensibilidade'. Basta pensarmos nas guerras, no trânsito, nos armamentos nucleares, na miséria, no desprezo pelo meioambiente, nas tiranias, no terrorismo...

Tudo isso está bem diante de nossos olhos, embora por insensibilidade nem sempre o consigamos enxergar. Está nas fachadas de vidro, que refletem o ambiente, devolvendo-lhe a imagem e se fazendo muito mais intransponíveis que as velhas muralhas de pedra. Está nos óculos escuros, que as pessoas usam com cada vez maior assiduidade, escondendo o olhar e permitindo ao outro apenas o reflexo de si e de seu próprios olhos. Está no walkman, no computador e nas redes de informação, que nos 'plugam' a nós mesmos. Está nos automóveis climatizados e com vidros fumês, em que nos encapsulamos, para termos o mínimo possível de sensações vindas do exterior. Está nos funcionários que trabalham nos balcões das empresas, prepostos que, sem assumir responsabilidade pelas mesmas, aliviam seus proprietários das culpas pelas crueldades que muitas vezes são constrangidos a praticar... Por estas e outras vias, não procurando mais o olhar do outro, fugindo dele e de seus sentidos, terminamos por não mais nos divisar ou sentir.

O sensível, desse modo, restringe-se - e cada dia mais - ao círculo de um 'eu' ilusoriamente todo-poderoso. Por esta razão, reclama-se por toda parte que os cidadãos se sintam pouco interessados pela dimensão pública da vida; que haja falta de motivação e indiferença pelas coisas e pessoas da política; que os eleitores não saibam votar, deixando-se iludir pela propaganda e comportando-se com res- 
peito ao voto como um consumidor em relação a um sabonete; que não haja participação e assim por diante. $\mathrm{O}$ fato é que, quando triunfa a individualidade, $\mathrm{o}$ coletivo se torna mera imagem, apenas cenário. Torna-se não mais que um teatro, em que o indivíduo acaba sendo chamado a desempenhar o papel de astro.

Ora, nada vejo aí a estranhar. Afinal de contas, o que se poderia esperar de indivíduos atomizados, absorvidos em si mesmos, dedicados ao que Simmel (1991) designava por self cultivation? O que seria possível aguardar destes seres humanos que narcisisticamente amam o amor que lhes é dedicado, muitíssimo mais do que as pessoas que os amam? Que eles parassem de 'delegar' o que é de interesse 'apenas' coletivo? Que renunciassem ao privilégio de não se preocupar senão consigo mesmos e com o círculo cada vez mais restrito dos seus afetos? Que realizassem a renúncia de si, em favor da Revolução, da Nação ou do Partido?

Uma rápida anedota pode ilustrar essa situação: Um conferencista, a certa altura de sua palestra, afirma: - Os cientistas calculam com base segura que o mundo deverá acabar no máximo dentro de um bilhão de anos. Assustado, um dos ouvintes interrompe, levantando-se subitamente da cadeira: - Quanto?! - Um bilhão de anos, repetiu o conferencista. Aliviado, o ouvinte retorna a seu lugar, totalmente descontraído: - Ainda bem, havia entendido 'um milhão'.

A profilaxia absoluta é mortal. No território superprotegido que a profilaxia delimita, o corpo acaba perdendo as suas defesas e as suas capacidades de coexistir. Sabemos que nas salas de cirurgia a assepsia é de tal modo rigorosa, que, em tese, nenhum micróbio, nenhuma bactéria aí deveria sobreviver. Acontece, no entanto, que é exatamente nestes lugares que estão aparecendo as doenças virais mais misteriosas, mais anômalas e de mais difícil controle. Algo de implacavelmente patológico há na desinfecção, que de forma alguma estava no programa ou nos sonhos dos higienizadores. Para lembrar as palavras de Baudrillard (1990:69), este algo vai fazendo de todos nós, de modo efetivo ou puramente paranóico, "virtuais imunodeficientes".

Deveríamos saber muito bem que, para poderem manter um mínimo de segurança, as usinas e arsenais nucleares resultam na exigência de parafernálias bélicas e aparatos de controle e vigilância que necessariamente requerem um Estado patologicamente militarizado, agigantado e ameaçador. Isto vale mesmo em tempos pacíficos e apesar dos muitos e muitos tratados de não-proliferação de armamentos. De modo muito semelhante, deveríamos saber também que não estamos nem um pouco livres dos efeitos colaterais decorrentes das medidas de segurança, controle e prevenção que a profilaxia acarreta, mesmo que aqui limitemos nosso raciocínio às manifestações mais moderadas desses efeitos. Protegidos pelas defesas artificiais dos artefatos e medicamentos industriais, perdemos as defesas espontâneas que todo organismo vivo possui. Desprovidos destas, tornamo-nos dependentes das parafernálias artificiais (antibióticos, anti- 
histamínicos etc.). A cobra termina por morder o próprio rabo, e acabamos devorados por um redemoinho imprevisto.

Além disso, sobretudo após as experiências do nazismo e do apartheid, alguns dos subprodutos já conhecidos da higienização deveriam ser mais do que suficientes para não nos permitir esquecer das verdadeiras catástrofes apocalípticas que podem decorrer de idéias em aparência tão ingênuas e neutras como as de pureza, separação, evitação de mistura, perigo de contágio, que estão envolvidas existencialmente neste primeiro estilo de corporalidade. Deveríamos reconhecer o quão dolorosamente longe foram capazes de chegar a insensibilidade e o distanciamento propiciados pela racionalidade e pelo cálculo, pela objetividade e pelo pragmatismo 'limpos'. Mas, em lugar disso, com freqüência podemos nos surpreender incapazes de sentir a diferença entre cinqüenta, um milhão e um bilhão de anos!

Há exatos cinqüenta anos, ao se amontoarem com tratores os cadáveres deixados pela Alemanha nazista, descobriram-se o horror de suas atrocidades, a grandeza dos crimes contra a humanidade e o extermínio de seis milhões de judeus. Esta barbárie, perpetrada por uma sociedade tão 'avançada' como a alemã, não deveria abalar as certezas sobre o sentido da história? E não nos deveria fazer pensar dubitativamente sobre o avanço das civilidades, assim como da sensibilidade que lhes é característica? A capacidade exponencial de destruição, que os bombardeios de Hiroshima e de Nagasaki materializaram, não nos deveria fazer - pessoas tão 'sensíveis', como sempre autoproclamamos ser - muito mais inquietos do que costumamos estar? Que dizer então das ameaças que Chernobyl apenas prefigurou, mas cujas probabilidades nunca se ignoraram?

Enfim, como se pergunta o historiador François Dosse no âmbito dessas mesmas ansiedades: "Saberá a razão triunfar sobre a barbárie? Tudo é incerto após esses desastres" (1994:102). Prenunciando as reflexões de Hannah Arendt (1979) sobre as relações entre totalitarismo e atomização de indivíduos isolados, há muito Alexis de Tocqueville já nos havia advertido, em seu De la Démocratie en Amérique: "O despotismo, que é temeroso por natureza, vê no isolamento dos homens a garantia mais segura de sua própria duração, e geralmente dedica todos os seus esforços a isolá-los (...). Considera bons cidadãos os que se fecham estreitamente em si mesmos".

Eainda mais:

Trato de imaginar sob que novos traços poderá aparecer o despotismo no mundo, vejo uma multidão incontável de homens parecidos ou iguais que giram sem cessar sobre si próprios, procurando prazeres pequenos e vulgares que ocupem sua alma. Cada um deles, separado dos demais, é estranho a seu destino; seus filhos e amigos constituem, para ele, toda a espécie humana; está perto de seus concidadãos e vizinhos, mas neles não repara; toca- 
os sem os sentir; não existe mais do que em si mesmo e para si e, se ainda lhe resta uma família, pode-se dizer que já não tem pátria. Acima desta massa se ergue um poder imenso e tutelar que se encarrega com exclusividade de garantir os direitos de todos e de controlar seu destino (...).

Entre tantos outros, Foucault nos demonstrou que a noção de indivíduo é um artefato ideológico que vai sendo construído e solidificado pelos poderes da sociedade disciplinar, mediante microprocedimentos que pouco a pouco esculpem seres humanos dotados de limites muito definidos, os quais os separam de um exterior e que preservam um interior cada vez mais singular, privado, subjetivo, íntimo, secreto... Como as páginas anteriores nos têm sugerido, todos estes traços estão profusamente presentes nesta primeira filosofia corporal.

Ilustrações banais - muito cotidianas e bastante características dos tipos de concepções corporais e comportamentais que decorrem da noção de indivíduo são as atitudes que habitualmente devemos manter em circunstâncias bem costumeiras, como salas de espera, transportes públicos, elevadores, multidões. Nessas situações, o distanciamento dos corpos acaba colocado em questão, brotando uma espécie de incômodo ou mal-estar, que deriva do contato físico obrigatório, da mera aproximação de alguma coisa que esteve em contato com as mãos, com a boca, com qualquer parte do corpo de outra pessoa, ou mesmo decorrente de sua simples presença. Um mal-estar que se pode manifestar como mero embaraço passageiro, mas que muitas vezes toma a forma de um sentimento muito visceral de nojo.

A teatralidade social nos aconselha, nesses casos de proximidade corporal, um estranho e bizarro fingimento, que pode até mesmo nos obrigar a parar de sentir, a fim de não demonstrar sentimento. Movido pela precaução de evitar aborrecimentos posteriores, ou pelo medo de uma dor futura, às vezes o indivíduo se habitua a tal ponto a inibir suas emoções, que não é mais capaz de qualquer forma de expressão. Cada ser humano, por assim dizer, passa a ter que se enfrentar a si mesmo: a ter que disfarçar as paixões, a rejeitar os ditames do coração, a evitar agir sob emoção. Por este meio, deve-se reciprocamente fazer de conta que o que vale é uma extrema e ambivalente indiferença ao outro, como se ele não estivesse lá. No limite desse fingimento, as máscaras acabam se transformando em rostos e fica difícil distinguir a insensibilidade que se finge da insensibilidade que se vive.

De certa maneira, este modo individualista de conceber o corpo e a existência funda ou incentiva a mentira. Em primeiro lugar, porque cria a esfera do secreto individual, isto é, uma interioridade a ser preservada por todos os meios, contra quase qualquer exterior (autoridade pública, outros indivíduos etc.). Em segundo lugar, porque a mentira protege contra a intervenção do Estado nas questões individuais, familiares e comunitárias. Em terceiro, porque os conteúdos do íntimo e do privado sempre se tornam públicos de algum modo, transformando-se em 
mercadorias avidamente consumidas. É o caso, por exemplo, das fofocas sobre a intimidade de personalidades públicas, dos romances, das biografias e autobiografias, em especial daquelas que se rotulam de sensacionais ou sensacionalistas. É também o caso dos filmes e revistas pornográficos. Nesses últimos, temos ilustrações quase paradigmáticas, em que a superexposição da privacidade de outrem ou a abertura de uma espécie de privado 'em geral' - de um íntimo mais ou menos coletivo ou público - cumpre o papel sociológico de fornecer ao privado individual um modelo em que se plasmar (modelo, aliás, quase sempre platonicamente irrealizável). Por fim, a mentira se vê favorecida porquanto o modo individualista de ser inventa o palco de encenação em público do papel de indivíduo privado original, embora este original se dê sempre consoante um sistema padronizado, geral e coletivo de expectativas de comportamento, por cujo intermédio a originalidade acaba paradoxalmente banalizada.

Como observou Norbert Elias, "a idéia de que pessoas estranhas possam ser parte integrante da formação de sua individualidade parece hoje em dia quase uma transgressão dos direitos do sujeito sobre si mesmo" (1994a:53). Esta é a razão pela qual devemos mutuamente proceder como se estivesse cada um dentro de uma bolha. Como se fôssemos células envolvidas por membranas. Como se o calor e o odor do outro fossem inexistentes. Como se os corpos fossem transparentes na direção de dentro para fora. Como se através deles se pudesse olhar para qualquer lugar. Como se tudo além de si (assim mesmo com ressalvas) requeresse atitudes de evitação.

Tais atitudes de evitação se tornam necessárias, todavia, apenas se os olhos por acaso ou descuidadosamente se tiverem repousado sobre corpos vizinhos coisa que em princípio deveria ter sido evitada. Sabemos que a visão era um sentido de importância menor para os homens da Idade Média. Transformou-se, desde o Renascimento e o Século das Luzes, no sentido por excelência da cultura moderna, precisamente por ser o menos afetivo, por ser o da distância, o da comunicação sem contato. O olhar, único sentido socialmente admitido nesta civilização do "ver para crer", mesmo assim tem algo de violação: no jogo interativo, mede-se por milimétricas frações de segundo, a menor delonga insinuando intencionalidades escusas. Eis, pois, o mais interessante: por um passe de mágica, a visibilidade dos corpos decretou exatamente sua inexistência. Transformou sua presença ostensiva em ausência. Aniquilou-os.

Este passe de mágica se materializa, à primeira vista, apenas como uma espécie de rejeição ritual das manifestações do corpo - recusa bem característica deste primeiro tipo de corporalidade. Diante de um rumor estomacal, de um flato, de uma eructação e mesmo de uma lágrima... é preciso mentir e dar a impressão de que nada se ouviu, cheirou ou enxergou. Em algumas dessas situações talvez até mesmo risos compareçam - mas este deslize da norma de fingimento e discrição ocorrerá em geral para expressar a vontade impiedosa de humilhar aquele que não conseguiu se conter nos limites do seu corpo. Estes 
risos que algumas vezes acompanham as manifestações corporais representam hoje mais crueldade do que singela expressão de um sincero à-vontade com a tagarelice dos orifícios.

Um modo cultural de conceber o corpo é o que está atuando nesses casos, ditando uma ética. Assim como uma ética da destruição pôde conceber tanques movidos a energia solar para fazer guerra nos desertos - alertando-nos para o fato de que é preciso relativizar com muito cuidado as questões da ecologia e do pacifismo - a 'liberação' do corpo não significa automaticamente libertação de uma determinada ética corporal. Não bastaria simplesmente cortar as amarras corporais e deixar que o corpo falasse livremente. Sabemos muito bem que, quando não há a preocupação de silenciar o corpo, esta liberalidade e sinceridade derivam quase sempre de um desrespeito que exprime latente desprezo pelo outro, de um desrespeito que resulta da indiferença. Correspondem a um desrespeito que configura desdém, autorizado por sentimento de suposta superioridade social.

Como conseqüência coerente de tudo isso, os mínimos toques, ruídos, olhares, palavras... que violem as paredes da bolha que envolve cada um de nós e que atribuam ao corpo algum peso, fazendo-o existir, deverão ser conjurados imediatamente por ritos de desculpabilização ou por silêncios. Estes ritos e silêncios ocupam-se de missões significacionais, cujo objetivo imediato é tentar suprimir uma sensação de constrangimento ou de vergonha. Este doloroso sentimento de vergonha é passível de derivar da simples, mas gravíssima, falha de eu ter feito da presença de meu corpo um fardo. De eu singelamente ter feito dele um ser existente. E isto se explica em virtude de se terem tornado verdadeiros pesadumes segundo esta primeira maneira de conceber a corporalidade - tanto a minha existência para o outro, como a dele para mim.

Nem mesmo se trata mais, a rigor, de contato corporal. O distanciamento ditado por esta primeira forma de corporalidade passou a ser muitíssimo mais exigente. Desde a segunda metade do século passado, desenvolveram-se em Paris e Londres - e depois em outras capitais do Ocidente - modelos de comportamento interpessoal totalmente singulares, que eu mesmo ainda desconhecia quando, um século após, fui habitante dessas cidades. Para mim, por exemplo, por volta de 1980, foi uma novidade surpreendente, de difícil aprendizado, a descoberta de que pessoas que não se conhecessem estavam praticamente proibidas de se dirigir a palavra, salvo - mesmo assim em casos muito especiais - se a abordagem começasse por expressões como scusi!, pardon!, excuse me!, entschuldigung!, desculpeme!, atenuadoras da verdadeira violação que se estava prestes a cometer.

Este costume de se pedir desculpas por dirigir a palavra não existia ainda no Rio de Janeiro, onde eu residia anteriormente, e não se tinha estabelecido plenamente na Europa até o século XIX, mesmo que já se exibisse muito fortemente em alguns contextos sociais do século XVIII. Foi somente a partir de então que se institucionalizou a norma segundo a qual, conservando a expressão de Richard 
Sennett, "estranhos não tinham o direito de se falar (...) todo homem possuía, como um direito público, um escudo invisível, um direito a ser deixado em paz" (1989:43). Isto se deu contrariando uma longa e riquíssima tradição de liberdade do falar, que ia da igreja à praça pública, da praça ao café, da cúpula à base das estratificações (Farge, 1992). Isto se deu depois de séculos e séculos de uma liberdade que envolvia exageros, xingamentos, expressões chulas, relações jocosas...

Vejo nesses costumes uma patética tentativa, que a longo prazo poderá se revelar ilusória, de usar como princípio de ordem pública uma passividade que se supõe - talvez de modo errôneo - inerente ao silêncio. Certamente esta mútua implicação entre silêncio e passividade não se dá de maneira tão automática ou irreversível. No plano individual, é preciso ainda colocar em evidência que, em contextos interativos governados por esta inspiração silenciadora, o medo de infringir as proibições sociais pode assumir um caráter extremo, interiorizando incisivamente em cada ser humano, sob a forma rigorosa de tabus, as instâncias mais severas de punição - instâncias que outrora residiam fora dele. Assim, as transgressões dessas regras passam a expor cada ser humano ao risco simultâneo de vergonha íntima e de ridicularização pública. Configuram uma ameaça de perda do prestígio e da estima sociais, por um lado. Mas, também, por outro, fazem coincidir dramaticamente a transgressão e a punição, acarretando que a primeira, no tribunal que cada pessoa passa a ter dentro de si, implique de modo automático a segunda - especialmente sob as formas sutis dos mais secretos e dolorosos remorsos, dos mais destruidores e discretos abalos na auto-estima.

No fundo desses sentimentos punitivos, repete-se um mesmo recado. $\mathrm{O}$ indivíduo que permite a si e a seu corpo que falem livre ou indisciplinadamente demonstra ter fracassado no mais sagrado dos trabalhos de si sobre si. Dá mostras de não ter absorvido a mais fundamental das normas de existência na nova sociedade, que consiste na habilidade de subjetivar o coletivo macroscópico no individual mais íntimo. Exibe sua inépcia em desenvolver a capacidade de transformar restrições externas em auto-restrições. Evidencia sua incompetência em se portar como um 'sujeito' sujeito. Termina, por conseguinte, punido. Acaba, por vias de conseqüência, punindo-se. Punido por não se ter deixado 'assujeitar'. Castigando-se a si próprio por estas mesmas razões.

Os resultados dessa política do silêncio são expressivos. Segundo dados apresentados por Gilles Lipovetsky (1991), entre 1962 e 1982 o número de pessoas que viviam sozinhas aumentou em 69\% na França. Em 1987 eram cerca de cinco milhões. Um em cada quatro domicílios contava com apenas uma pessoa. Mas este é um número geral para a França, já que, em Paris, nessa mesma época, nada menos do que a metade dos 'lares' era habitada por indivíduos que viviam sós. Isto não quer dizer, absolutamente, que estes indivíduos vivam sempre bem acompanhados de si mesmos. Sim, porque é desse absurdo semântico - viver acompanhado de si que se trata, uma vez que, conforme as novas concepções governadas pela primei- 
ra forma de corporalidade, a razão, a inteligência, a mente, a consciência, o sentimento etc. "têm sede em meu corpo, mas são diferentes de meu corpo". Constituem uma espécie de "coisa descoisificada" (Elias, 1994a:95), com a qual não se tem necessária ou automaticamente uma boa vizinhança.

As pessoas idosas, sabemo-lo muito bem, experimentam um estado de isolamento cada vez mais dramático. Que poderíamos dizer da proliferação dessas associações em favor das pessoas solitárias, que se multiplicam escancaradamente? E dos anúncios em jornais, que imploram, em tom de quase desespero, por companhia, afeto ou contato, e em que as pessoas vão de modo incessante e frustrante à procura de si mesmas, por meio desses órgãos de contato por excelência que são os que - sinal dos tempos - se passou a chamar de aparelho sexual? O que nos dizem os serviços de sexo (isto é, de masturbação) por telefone? A sexualidade passa a estar em toda parte e, ao mesmo tempo, em parte alguma. Transforma-se em algo que se volatiliza na promiscuidade dos muitos instantes, dos múltiplos, efêmeros contatos. Que pensar do fato de o sexo solitário ter passado a ser encorajado, tendo em vista uma sexualidade 'saudável' (Giddens, 1992), e de se ter quase transformado em modelo cultural - a ponto de um grande pensador contemporâneo ter podido afirmar ser esta a civilização da ejaculação precoce e da masturbação?

Que dizer dos S.O.S. tudo? E dos suicídios, além das tentativas fracassadas? O número de suicídios e de tentativas de auto-extermínio é alarmante: em 1985, a mortalidade por suicídio na França superou, pela primeira vez, a ocasionada pelos acidentes de trânsito. Enquanto perto de doze mil pessoas se matam a cada ano, os suicídios frustrados são seguidos, em 30 a $40 \%$ dos casos, de uma reincidência rápida (Lipovetsky, 1991). Caberia lembrar, neste ponto, para termos uma perspectiva do significado histórico e cultural desta questão, que a palavra suicídio não existia na Idade Média. Ela apareceu somente entre os séculos XVII e XVIII, primeiro na Inglaterra, depois na França (1734), associada ao fato de terem sido colocadas em questão as atitudes tradicionais com relação ao valor da vontade individual. Decorreu também de se ter abandonado a idéia medieval de que era possível cometer um crime contra si mesmo (Schmitt, 1976), teoria que se sustentava no princípio, cada vez mais incompreensível para nossos contemporâneos, de que este 'si' constituísse antes de tudo um 'nós'.

O império desta primeira concepção de corporalidade é o do individualismo e dos meios de comunicação a distância. A era do individualismo e dos meios de comunicação é inseparável da ruptura da comunidade e da dificuldade comunicativa. Não nos iludamos: a parafernália de comunicação, que se justifica como um facilitador de comunicação, não é senão o sintoma dessa dificuldade bastante típica de uma sociedade de 'eus' desvinculados de quaisquer 'nós'. Por isso, em todos os lados observamos pessoas que se queixam de não serem compreendidas ou ouvidas, de não se conseguirem expressar. Mesmo na intimidade da família, ou talvez principalmente nela, sabe-se que o silêncio é o que tem vigorado. 
Entretanto, quando falam, essas mesmas pessoas tratam apenas de si próprias, não estando nada dispostas a escutar. A indiferença e a apatia generalizadas passaram a constituir, ironicamente, o reverso da medalha do direito à diferença: 0 individualismo fez da diferença um imperativo radical, e isto resultou no paradoxo de tudo ser indiferente, ou seja, em nada ser deveras importante. Defender o direito à diferença tornou-se bom senso e senso comum, pois afinal nada é retoricamente tão fácil quanto defender o direito do outro à diferença, quando este outro se tornou indiferente para mim - e eu para ele. Por esta razão, entre tantas e tantas outras, veio a ser bem compreensível que muitos se vissem obrigados a alugar, por horas 'taximetricamente' contabilizadas, algum ouvido, que passaram a trocar por moedas. Não estamos diante de conseqüências bastante características da ascendência social do silêncio?

Nesta primeira concepção de corpo, encontramos ainda um paradoxo irônico. Alguém que se afaste compulsivamente das fontes de poluição que ameaçam seus limites não poderá sequer se relacionar com aqueles a quem transfira a tarefa de limpar, pois estes procuradores estariam logicamente 'sujos' - decorrência evidente dos contatos que são obrigados a manter. Este alguém obcecadamente higiênico muito menos poderia realizar por conta própria, sob pena de poluição, o trabalho de purificar, pois esta tarefa constitui uma atividade eminentemente delegável e transferível. Tal distanciamento oficioso, muito bem o ilustram certas profissões - que vão desde lixeiros e coveiros até carrascos, policiais e torturadores -, ofícios que se dedicam a executar para as 'boas' pessoas, muitas vezes sem seu conhecimento sequer (Hughes, 1967), a missão suja, embora social e politicamente 'necessária', de fazer uma 'limpeza', livrando-as dos dejetos, dos criminosos, dos perigosos, dos subversivos, dos parasitas...

$\mathrm{Na}$ impossibilidade de realizar pessoalmente estas tarefas de despoluição já que mesmo os instrumentos destinados a fazer o trabalho de limpeza se impurificam, passando eles próprios a requerer purificação -, aquele que se quer radicalmente limpo aguarda, paradoxalmente, o destino de se afogar na areia movediça de toda a sujeira que mais cedo ou mais tarde se acumulará em suas proximidades e o fará submergir. Aprendemos com isto que o problema simbólico da poluição representa algo criticamente insolúvel e que a sujidade acaba por ser essencialmente indelével. Quem o queira resolver de forma radical deverá escolher entre alternativas esdrúxulas: sair do mundo pela pasteurização de si, embalando-se a vácuo, por um lado, ou, por outro, fracassar obrigatoriamente na separação de si, pelo inevitável crescimento simbólico da imundície em que não quer e não pode tocar.

Esses limites paradoxais da concepção de limpeza deixam evidenciado que, na verdade, e bem ao contrário do que estamos habituados a pensar em nossa cultura, o problema da poluição não é fundamentalmente um problema de higiene. É assunto de magia - para o pasmo dos que sempre o consideraram uma questão 
de ciência. O contágio e a contaminação que lhe estão associados são antes de caráter simbólico. Dizem mais respeito ao que Durkheim e Mauss poderiam chamar de "higiene mística" ou "cósmica", que propriamente a uma higiene material. Tal higiene, como pudemos ver, precedeu a descoberta, muito recente, dos microorganismos patogênicos, base de nossas concepções cientificistas. Na raiz, a higiene não é, portanto, uma questão de microbiologia: podemos fazer a desinfecção que quisermos, podemos aniquilar germes e bactérias, não eliminaremos o desafio mágico que a sujeira comporta.

De qualquer forma, mesmo que em suas últimas conseqüências as concepções dessa primeira maneira de encarar o corpo se revelem utópicas e apenas em parte realizáveis, elas terminaram por configurar historicamente um tipo de ser humano bastante angustiado, em cuja vida quase todos os rituais que antes se praticavam de maneira pública, coletiva e ostensiva (sacrifícios, orações, confissões, expiações, comunhões, celebrações) foram como que silenciados, terminando interiorizados em cada indivíduo singular, que passou a encenar dentro de si os dramas que antigamente projetava para o exterior de si.

Este modo de ser representa no mínimo uma parte muito atuante da sensibilidade de cada um de nós: a sensibilidade de alguém separado de si, pela vivissecção que é obrigado a se auto-aplicar, distinguindo em si mesmo espírito e matéria, corpo e alma, eu e meu corpo; a sensibilidade de um ser humano distanciado dos outros corpos, em virtude da progressiva preponderância de uma organização social de inspiração individualista sobre outra mais holista ou comunitária, mais freqüente na experiência da humanidade; sobretudo, enfim, a sensibilidade de um corpo, individual, limpo, subjetivado, objetivado e objetificante corpo de alguém cirurgicamente afastado do cosmos, de alguém em cuja carne não se pode sentir a carne do mundo. É importante termos em mente que o processo de individualização, a que devemos o primordial do que somos, existe no âmbito de uma fortíssima tendência histórica à fragmentação de tudo. Desta tendência, o processo de formação da individualidade não constitui senão um capítulo. Depois, o próprio indivíduo será fragmentado.

$\mathrm{Na}$ outra vertente, como eu ia dizendo páginas atrás, existem perspectivas corporais diferentes, que os antropólogos conhecem muito bem, por decorrência de suas experiências com sociedades não-ocidentais. Nesta vertente não se diferencia dualisticamente o homem de seu corpo, nem se separa este último da pessoa. Os antropólogos reconhecem sem dificuldade essas maneiras de existir, tão fartas no cotidiano etnográfico, em que corpo e cosmos são assumidamente da mesma substância. Todavia, vale a pena observar que ser antropólogo não é de modo algum uma pré-condição deste reconhecimento.

Este segundo corpo, que na verdade é existencial e historicamente primeiro, pode estar em cada um. Na dança, no esporte lúdico, na embriaguez do transe, nas vibrações dos êxtases... Mesmo furtivamente, cada um de nós pode ter tido a 
chance de conhecê-lo, ainda que na solidão da intimidade com o outro, naquelas raras circunstâncias em que a teatralização artificial e cheia de maneirismos de nosso cotidiano deixou de ter sentido e em que as emoções destemperadas, as impudicícias, as confissões do mais indecoroso, apaixonado e desregrado erotismo puderam emergir e inundar o nosso ser, fazendo de nós 'des-possuidores' de nós mesmos: ímpetos tão intensos de vida, que são quase um equivalente da morte (Bataille, 1957).

Para esta outra perspectiva corporal, trata-se basicamente de 'ser' um corpo. Não existe para ela qualquer solução de continuidade entre o ente humano e o corpo. Não há qualquer pergunta a si mesmo sobre sua existência. Há identidade de substância entre a carne do homem e a carne do mundo. Vidas independentes das corporalidades pulsantes em que elas se realizam simplesmente são inexistentes, incogitáveis para esta perspectiva corporal e sua sensibilidade. O corpo, neste caso, remete sempre a si e aos outros corpos ao mesmo tempo, sendo essencialmente no plural. Não é de modo algum isolável daquele a quem atribui um rosto e de quem é o único indício de existência. Também não é separável daqueles com quem coexiste. Característico de ambientes sociais comunitários, este corpo não tem funções delimitadoras. Não é propriedade privada. Não é eminentemente uma marca de identidade social. Não é máscara. Não é indicador de um personagem. É a própria realidade da pessoa.

Menos que signo de um indivíduo, ou marca de sua diferença e distinção, esse corpo é exatamente onde o homem transborda de si, onde recusa a inércia e os confortos que o tornam passivo e dócil. Esse corpo é, de maneira aparentemente paradoxal, onde ele se funde, se dissolve e se constitui. O ser humano deste corpo não configura um mundo interior, fechado, no qual deva penetrar para se encontrar a si mesmo ou, antes, para se descobrir. O ser humano deste corpo é extrovertido. Ele é muito mais superfície que profundidade. Especialmente, é o lugar em que estas se revertem reciprocamente. Sua consciência (de si ou qualquer outra) está sempre ancorada no exterior. Nele, a consciência de si "é a apreensão de um ele, não ainda de um eu", para retomar a bela fórmula referida por Jean-Pierre Vernant (1988:38-9).

Voltemos à magia. Este modo de existência corporal tem a ver com o fascínio que, por toda parte, os homens têm por romper os limites, pelo além, pelas viagens, pela transgressão das fronteiras, pela ida ao desconhecido, pelos transes, pela morte, pelo convívio extático com os deuses... Sabemos que todos os que vão 'lá' retornam acrescidos de um prestígio especial, com poderes perigosos ou benfazejos, conforme o caso, mas raramente neutros. Depois desta viagem, ficam como que ungidos e enriquecidos por um outro poder - o que os glorifica e os autoriza a serem chefes, xamãs, algo ou alguém particularmente respeitado por si e pelos outros. E isto por terem saído de si, por terem transbordado, por terem conhecido ou tocado o desconhecido, por os deuses estarem neles, ou entre eles. 
Este outro corpo é isto: nele, o trágico nunca fenece; busca decididamente o que o põe em perigo. Os contra-poderes e as ameaças são absorvidos por ele como positivos, para que, usando-os como alimento, continue incessantemente a se renovar. Não admite maniqueísmos. Não comete os pecados filosóficos de imaginar que o mal seja extirpável e que a felicidade esteja alhures. Reconhece que as melhores coisas da vida (sobretudo a própria) contêm inexoravelmente um risco de morte. Corpo fluido, que se desfaz ao mesmo tempo em que a vida o constitui. E que se constitui ao mesmo tempo em que a vida o desfaz. Tal corpo não vive. Convive. 


\section{Referências Bibliográficas}

Arendt, H. Totalitarismo, o Paroxismo do Poder. Rio de Janeiro: Documentário, 1979. ArIÈs, P. Essais sur l'Histoire de la Mort en Occident. Paris: Seuil, 1975.

Ariès, P. L'Homme devant la Mort. Paris: Seuil, 1977.

Ariès, P. História Social da Criança e da Família. Rio de Janeiro: Zahar, 1978.

Ariès, P. O Tempo da História. Rio de Janeiro: Francisco Alves, 1989.

Ariès, P. Por uma história da vida privada. In: ArIÈs, P. \& CHARTIER, R. (Orgs.) História da

Vida Privada III. São Paulo: Cia. das Letras, 1992.

Attali, J. L'Ordre Cannibale. Paris: Grasset, 1979.

Auerbach, E. Mimesis. São Paulo: Perspectiva, 1971.

Baeta Neves, L. F. O Paradoxo do Coringa. Rio de Janeiro: Achiamé, 1979.

BAKhtin, M. A Cultura Popular na Idade Média e no Renascimento. Brasília: UNB, 1987.

Balandier, G. O Poder em Cena. Brasília: UNB, 1982.

BArthÉlemy, D. Os arranjos do espaço privado. In: Duby, G. (Org.) História da Vida Privada II. São Paulo: Cia. das Letras, 1991a.

BarthÉlemy, D. Parentesco. In: Duby, G. (Org.) História da vida privada II. São Paulo:

Cia. das Letras, 1991b.

Bataille, G. L'Érotisme. Paris: Minuit, 1957.

Baudrillard, J. Le Mirroir de la Production. Bruxelas: Casterman, 1973.

Baudrillard, J. A Transparência do Mal. Campinas: Papirus, 1990.

Bergson, H. O Riso. Rio de Janeiro: Zahar, 1983.

Bloch, M. La Société Féodale. Paris: Albin Michel, 1968.

Bloch, M. Los Reyes Taumaturgos. México: Fondo de Cultura Económica, 1988.

Bourdieu, P. Algeria 1960. Cambridge: Cambridge University Press, 1979.

Bourdieu, P. Les rites comme actes d'institution. Actes de la Recherche en Sciences

Sociales, 43: 58-63, 1982.

Braudel, F. Capitalism and Material Life 1400-1800. Londres: Harper and Row, 1975.

Braudel, F. A Dinâmica do Capitalismo. Rio de Janeiro: Rocco, 1987.

Braunstein, P. Abordagens da intimidade nos séculos XIV e XV. In: Duby, G. (Org.)

História da Vida Privada II. São Paulo: Cia. das Letras, 1991.

Brown, P. A Antiguidade tardia. In: Veyne, P. (Org.). História da Vida Privada I. São

Paulo: Cia. das Letras, 1992. 
Burke, P. A Cultura Popular na Idade Moderna. São Paulo: Cia. das Letras, 1989.

BuRKe, P. Heu domine, adsunt turcae: esboço para uma história social do latim pósmedieval. In: BuRKe, P. \& PORTER, R. (Orgs.) Linguagem, Indivíduo e Sociedade. São Paulo: Unesp, 1993.

Castelnuovo, E. L'artiste. In: Le Goff, J. (Org.) L’Homme Médiéval. Paris: Seuil, 1989.

Cavalcanti, M. L. V. C. Carnaval Carioca. Rio de Janeiro: UFRJ/Funarte, 1994.

CHARTIER, R. Leituras, leitores e literaturas populares na Europa do Renascimento. Mana, 1(1), 1985.

Chartier, R. As práticas da escrita. In: Ariès, P. \& Chartier, R. (Orgs.) História da Vida Privada III. São Paulo: Cia. das Letras, 1992.

Chastel, A. O artista. In: Garin, E. (Org.) O Homem Renascentista. Lisboa: Presença, 1991.

Clastres, P. Arqueologia da violência. In: Guerra, Religião e Poder. Lisboa: Edições 70, 1980.

Collomp, A. Famílias. Habitações e coabitações. In: ARiès, P. \& ChARTIER, R. (Orgs.) História da Vida Privada III. São Paulo: Cia. das Letras, 1992.

Contamine, P. Os arranjos do espaço privado. In: Duby, G. (Org.) História da Vida Privada II. São Paulo: Cia. das Letras, 1991.

Corbin, A. Saberes e Odores. São Paulo: Cia. das Letras, 1987.

Corbin, A. Bastidores. In: Perrot, M (Org.) História da Vida Privada IV. São Paulo: Cia das Letras, 1991.

Crespo, J. A História do Corpo. Lisboa: Difel/Bertrand, 1990.

Dalarun, J. Amor e Celibato na Igreja Medieval. São Paulo: Martins Fontes, 1990.

DaMatta, R. Conta de Mentiroso. Rio de Janeiro: Rocco, 1993a.

DaMatta, R. Em Torno dos Pobres Urbanos no Brasil. 1993b. (Tese para o concurso para professor titular de Antropologia. Niterói: Universidade Federal Fluminense.)

Davis, N. Culturas do Povo. Rio de Janeiro: Paz e Terra, 1990.

Delarue, J. A Profissão de Carrasco. Lisboa: Livros do Brasil, 1980.

Delumeau, J. Naissance et Affirmation de la Réforme. Paris: P.U.F., 1965.

Delumeau, J. La Peur en Occident. Paris: Fayard, 1978.

Donzelot, J. A Polícia das Famílias. Rio de Janeiro: Graal, 1986.

Dosse, F. A História em Migalhas. Campinas: Unicamp/ Ensaio, 1994.

Douglas, M. Purity and Danger. Londres: Pellican Books, 1970.

DuBy, G. Guerreiros e Camponeses. Lisboa: Estampa, 1978.

DuBy, G. O Tempo das Catedrais. Lisboa: Imprensa Universitária, 1979.

DuBy, G. O Ano Mil. Lisboa: Edições 70, 1986.

Duby, G. Guilherme Marechal. Rio de Janeiro: Graal, 1988a.

DuBy, G. A Europa na Idade Média. São Paulo: Martins Fontes, 1988b.

Duby, G. Advertência. In: Duby, G. (Org.) História da Vida Privada II. São Paulo: Cia. das Letras, 1991a.

Duby, G. Convívio. In: Duby, G. (Org.) História da Vida Privada II. São Paulo: Cia. das Letras, 1991b.

Duby, G. A solidão nos séculos XI-XIII. In: Duby, G. (Org.) História da Vida Privada II. São Paulo: Cia. das Letras, 1991c. 
Dumont, L. Homo Hierarchicus. Paris: Gallimard, 1966.

Duvignaud, J. Lieux et Non Lieux. Paris: Galilée, 1977a.

Duvignaud, J. Le Don du Rien. Paris: Stock, 1977b.

Eco, U. Arte e Beleza na Estética Medieval. Rio de Janeiro: Globo, 1989.

Elias, N. O Processo Civilizador I. Rio de Janeiro: Jorge Zahar, 1990.

Elias, N. O Processo Civilizador II. Rio de Janeiro: Jorge Zahar, 1993.

Elias, N. A Sociedade dos Indivíduos. Rio de Janeiro: Jorge Zahar, 1994a.

Elias, N. Mozart: sociologia de um gênio. Rio de Janeiro: Jorge Zahar, 1994b.

Farge, A. Famílias: a honra e o sigilo. In: Ariès, P. \& Chartier, R. (Orgs.) História da

Vida Privada III. São Paulo: Cia. das Letras, 1992.

Febvre, L. Le Problème de l'Incroyance au XVI Siècle. Paris: Albin Michel, 1947.

Febvre, L. Histoire et psychologie. In: Chartier, Roger et.al. La Sensibilité dans l'Histoire. Paris: Gérard Monfort, 1987.

Flandrin, J. L. A distinção pelo gosto. In: Ariès, P. \& Chartier, R. (Orgs.) História da

Vida Privada III. São Paulo: Cia. das Letras, 1992.

Foucault, M. As Palavras e as Coisas. Lisboa: Portugália, 1968.

Foucault, M. L'Ordre du Discours. Paris: Gallimard, 1971.

Foucault, M. A verdade e as formas jurídicas. Cadernos da PUC-RJ, 1974.

Foucault, M. Surveiller et Punir. Paris: Gallimard, 1975.

Foucault, M. Naissance de la Clinique. Paris: PUF, 1978.

Foucault, M. Microfisica do Poder. Rio de Janeiro: Graal, 1982.

Foucault, M. História da Sexualidade I. Rio de Janeiro: Graal, 1985.

Geremek, B. Le marginal. In: Le Goff, J. (Org.) L'Homme Médiéval. Paris: Seuil, 1989.

GidDENs, A. A Transformação da Intimidade. São Paulo: Unesp, 1992.

GimpBeL, J. A Revolução Industrial da Idade Média. Lisboa: Europa-América, 1976.

GinzBurg, C. Mitos, Emblemas, Sinais. São Paulo: Cia. das Letras, 1988.

Goulemot, J. As práticas literárias ou a publicidade do privado. In: ARIÈs, P. \& ChARTIER,

R. (Orgs.) História da Vida Privada III. São Paulo: Cia. das Letras, 1992.

Gourevitch, A. Le marchand. In: Le Goff, J. (Org.) L'Homme Médiéval. Paris: Seuil, 1989.

Guerrand, R. H. Espaços privados. In: Рerrot, M. (Org.) História da Vida Privada IV.

São Paulo: Cia das Letras, 1991.

Guillaume, M. Éloge du Désordre. Paris: Gallimard, 1978.

Hauser, A. Historia Social de la Literatura y el Arte. Madri: Guadarrama, 1964.

HeErs, J. Carnavales y Fiestas de Locos. Barcelona: Península, 1988.

Hughes, E. Good people dirty work. In: Becker, H. (Org.) The Other Side. Londres: The

Free Press, 1967.

Huizinga, J. O Declínio da Idade Média. São Paulo: Verbo-Edusp, 1978.

Huizinga, J. Homo Ludens. São Paulo: Perspectiva, 1990.

ILlich, I. Némesis Médicale. Paris: Seuil, 1975.

JACOB, F. A Lógica da Vida. Rio de Janeiro: Graal, 1983.

Latouche, S. Le revers de la production. In: Traverses 12. Paris: Minuit, 1978.

LeACH, E. Cultura y Comunicación. Madri: Siglo XXI, 1978.

Le Breton, D. Anthropologie du Corps et Modernité. Paris: PUF, 1990. 
Lebrun, F. As reformas: devoções comunitárias e piedade pessoal. In: ArIÈs, P. \& CHARTIER, R. (Orgs.) História da Vida Privada III. São Paulo: Cia. das Letras, 1992.

Lecherbonnier, B. Carrascos de Paris. São Paulo: Mercuryo, 1991.

Le Goff, J. O Maravilhoso e o Quotidiano no Ocidente Medieval. Lisboa: Edições 70, 1975.

Le Goff, J. Para um Novo Conceito de Idade Média. Lisboa: Estampa, 1980.

Le Goff, J. (Org.) L'Homme Médiéval. Paris: Seuil, 1989.

LÉVI-STrauss, C. Antropologia Estrutural. Rio de Janeiro: Tempo Brasileiro, 1967.

LÉvi-Strauss, C. Raça e história. In: Raça e Ciência I. São Paulo: Perspectiva, 1970.

Lipovetsky, G. O Império do Efêmero. São Paulo: Cia. das Letras, 1991.

Lizot, J. População, recursos e guerra entre os Yanomami. In: Guerra, Religião e Poder.

Lisboa: Edições 70, 1980.

Macfarlane, A. A Cultura do Capitalismo. Rio de Janeiro: Jorge Zahar, 1989.

Mollat, M. Os Pobres na Idade Média. Rio de Janeiro: Campus, 1989.

Morin, E. L'Homme et la Mort. Paris: Seuil, 1970.

Mumford, L. A Cultura das Cidades. Belo Horizonte: Itatiaia, 1961.

Mumford, L. La Cittá nella Storia. Milão: Bompiani, 1977.

Nogueira, C. O Diabo no Imaginário Cristão. São Paulo: Ática, 1986.

Nora, P. Les Lieux de la Mémoire. Paris: Gallimard, 1984.

Pereira de Queiroz, M. I. Carnaval Brasileiro. São Paulo: Brasiliense, 1992.

Perrot, M. A vida em família. In: Perrot, M. (Org.) História da Vida Privada IV. São

Paulo: Cia das Letras, 1991.

Pirenne, H. As Cidades na Idade Média. Lisboa: Europa-América, 1964.

Propp, W. Comicidade e Riso. São Paulo: Ática, 1992.

Prost, A. Fronteiras e espaços privados. In: Prost, A. \& Vincent, G. (Orgs.) História da

Vida Privada V. São Paulo: Cia. das Letras, 1992.

Ranum, O. Os refúgios da intimidade. In: Ariès, P. \& Chartier, R. (Orgs.) História da

Vida Privada III. São Paulo: Cia. das Letras, 1992.

RÉGNIER-Bohler, D. Explorações de uma literatura. In: Duby, G. (Org.) História da Vida

Privada II. São Paulo: Cia. das Letras, 1991.

Ribeiro, R. J. A Etiqueta no Antigo Regime. São Paulo: Brasiliense, 1983.

Rodrigues, J. C. Tabu do Corpo. Rio de Janeiro: Achiamé, 1979.

Rodrigues, J. C. Tabu da Morte. Rio de Janeiro: Achiamé, 1983.

Rodrigues, J. C. Antropologia e Comunicação. Rio de Janeiro: Espaço e Tempo, 1989.

Rodrigues, J. C. Ensaios em Antropologia do Poder. Rio de Janeiro: Terranova, 1992.

Rodrigues, J. C. Higiene e Ilusão. Rio de Janeiro: Nau, 1995.

Roncière, C. de la. A vida privada dos notáveis toscanos no limiar da Renascença. In:

Duby, G. (Org.) História da Vida Privada II. São Paulo: Cia. das Letras, 1991.

Rossiaud, J. Le citadin. In: Le Goff, J. (Org.) L 'Homme Médiéval. Paris: Seuil, 1989.

Rossiaud, J. A Prostituição na Idade Média. Rio de Janeiro: Paz e Terra, 1991.

Rouche, M. Alta Idade Média Ocidental. In: Veyne, P. (Org.) História da Vida Privada I.

São Paulo: Cia. das Letras, 1992.

Sahlins, M. Stone Age Economics. Londres: Tavistock Publications, 1974.

Schmit, J. C. Le suicide au Moyen Age. Annales, 1:4-19, 1976. 
Sebe, J. C.. Carnaval, Carnavais. São Paulo: Ática, 1986.

Sennett, R. O Declínio do Homem Público. São Paulo: Cia. das Letras, 1989.

Simmel, G. On Individuality and Social Forms. Chicago: The University of Chicago Press, 1991.

THÉBERT, Y. Vida privada e arquitetura doméstica na África romana. In: Veyne, P. (Org.) História da Vida Privada I. São Paulo: Cia. das Letras, 1992.

Thomas, K. O Homem e o Mundo Natural. São Paulo: Cia das Letras, 1988.

Thomas, K. A Religião e o Declínio da Magia. São Paulo: Cia das Letras, 1991.

Tномаs, L. V. Anthropologie de la Mort. Paris: Payot, 1976.

Verger, J. As Universidades na Idade Média. São Paulo: Unesp, 1990.

Vernant, J. P. O indivíduo na cidade. In: Veyne, P. et. al. Indivíduo e Poder. Lisboa:

Edições 70, 1988.

Veyne, P. O Império Romano. In: Veyne, P. (Org.) História da Vida Privada I. São Paulo:

Cia. das Letras, 1992.

Vigarello, G. Le Propre et le Sale. Paris: Seuil, 1985.

Vincent, G. Uma história do segredo? In: Prost, A. \& Vincent, G. (Orgs.) História da Vida Privada V. São Paulo: Cia. das Letras, 1992.

Vovelle, M. Pieté Barroque et Déchristianization. Paris: Seuil, 1978. 
Formato: $16 \times 23 \mathrm{~cm}$

Tipologia: Bauer Bodoni BT e Times New Roman

Papel: Pólen Bold $70 \mathrm{~g} / \mathrm{m}^{2}$ (miolo)

Cartão Supremo $250 \mathrm{~g} / \mathrm{m}^{2}$ (capa)

Fotolitos: Engenho e Arte Editoração Gráfica Ltda. (capa)

Impressão e acabamento: Imos Gráfica e Editora Ltda.

Rio de Janeiro, julho de 2014

Não encontrando nossos títulos em livrarias, contactar a EDITORA FIOCRUZ:

Av. Brasil, 4036 - Térreo- sala 112 - Manguinhos

21040-361 - Rio de Janeiro - RJ

Tel.: (21) 3882-9039 e 3882-9007

Telefax: (21) 3882-9006

e-mail: editora@fiocruz.br

www.fiocruz.br/editora 